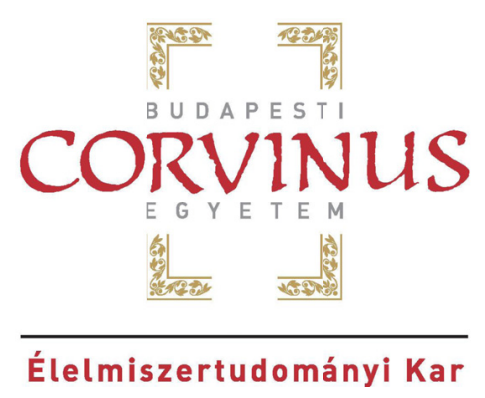

\title{
SZEMESTERMÉNYEK NEDVESSÉGTARTALMÁNAK ÉS DIELEKTROMOS JELLEMZÖINEK ÖSSZEFÜGGÉSE
}

\author{
Doktori értekezés
}

Készítette:

Gillay Bíborka Zsuzsanna

Konzulensek:

Dr. David B. Funk

Dr. Felföldi József

Budapesti Corvinus Egyetem

Élelmiszertudományi Kar

Fizika-Automatika Tanszék

Budapest

2013 


\author{
A doktori iskola \\ megnevezése: Élelmiszertudományi Doktori Iskola \\ tudományága: Élelmiszertudományok \\ vezetője: $\quad$ Dr. Fodor Péter, DSc \\ egyetemi tanár \\ Budapesti Corvinus Egyetem \\ Témavezetök: $\quad$ Dr. David B. Funk, PhD, DSc (hc) \\ Deputy Director, Chief Scientist \\ USDA- GIPSA Technology \& Science Division \\ Dr. Felföldi József, DSc \\ egyetemi tanár \\ Budapesti Corvinus Egyetem \\ Fizika-Automatika Tanszék
}

A jelölt a Budapesti Corvinus Egyetem Doktori Szabályzatában előírt valamennyi feltételnek eleget tett, az értekezés mühelyvitájában elhangzott észrevételeket és javaslatokat az értekezés átdolgozásakor figyelembe vette, azért az értekezés nyilvános vitára bocsátható.

The applicant met the requirement of the $\mathrm{PhD}$ regulations of the Corvinus University of Budapest and the thesis is accepted for the defence process.

Az iskola vezetô jóváhagyása

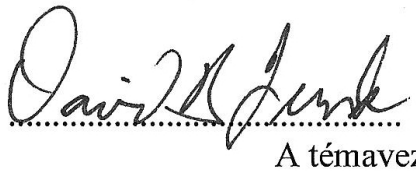

(Signature of Superviors) 
A Budapesti Corvinus Egyetem Élettudományi Területi Doktori Tanácsának 2013-03-05-i határozatában a nyilvános vita lefolytatására az alábbi bíráló Bizottságot jelölte ki:

\section{BÍRÁLÓ BIZOTTSÁG:}

Elnöke:

Vatai Gyula, DSc, BCE

Tagjai:

Salgó András, DSc, BCE

Kaffka J. Károly, CSc

Géczi Gábor, PhD, SzIE

Szalai Lajos, CSc

Opponensek:

Sembery Péter, CSc, SzIE

Fenyvesi László, PhD, VM Mezőgazdasági Gépesítési Intézet

Titkár:

Kovács Zoltán, PhD, BCE 



\section{TARTALOMJEGYZÉK}

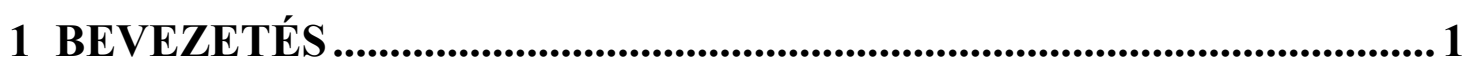

2 IRODALMI ÁTTEKINTÉS ....................................................................

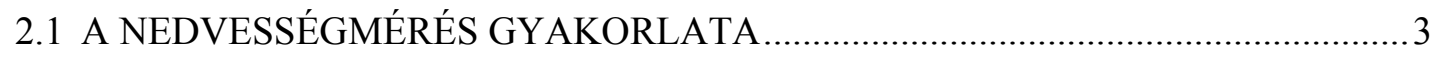

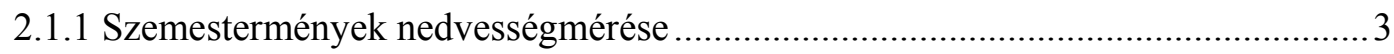

2.1.2 Gyors nedvességmérö technológiák ........................................................

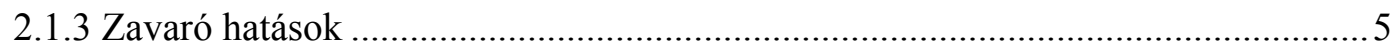

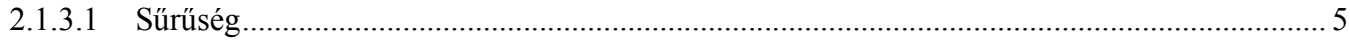

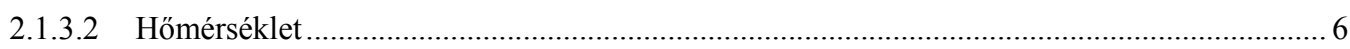

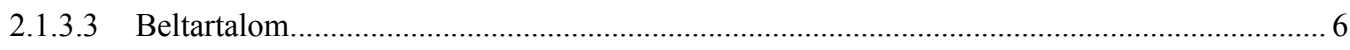

2.1.3.4 Szemeken belüli egyenlőtlen nedvességeloszlás .............................................................. 6

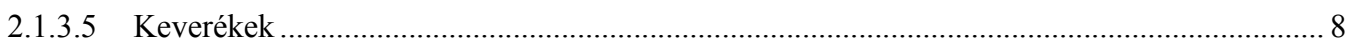

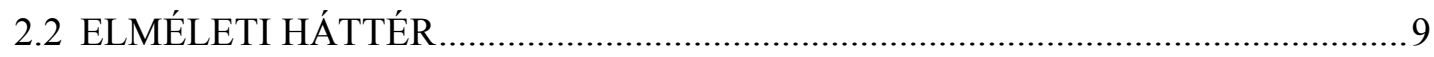

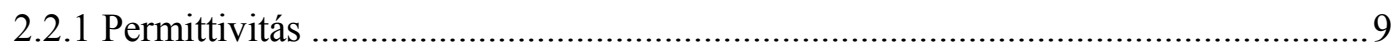

2.2.2 A permittivitás frekvencia függése ....................................................... 10

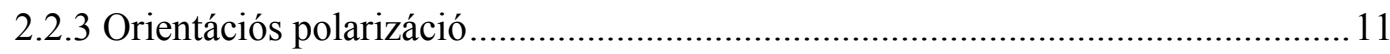

2.2.4 A vezetőképesség hozzájárulása a permittivitáshoz........................................ 12

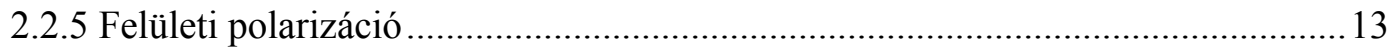

2.2.6 Keverék egyenletek és sürüségkorrekció ...................................................... 14

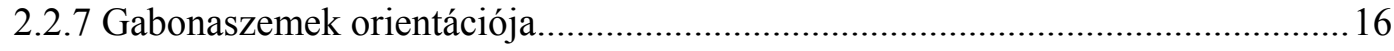

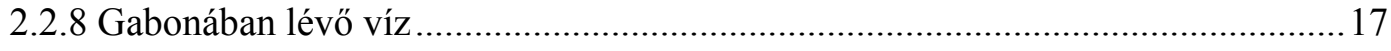

2.2.9 Argand diagramos ábrázolás ................................................................. 17

2.2.10 Gabonaminták áramköri modellezése ….......................................................... 19

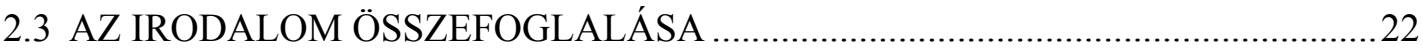

3 CÉLKITÜZÉSEK ......................................................................................... 23 
4 ANYAGOK ÉS MÓDSZEREK................................................................. 25

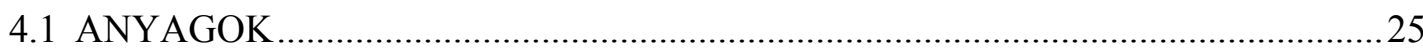

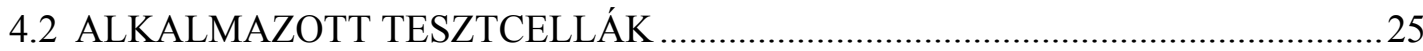

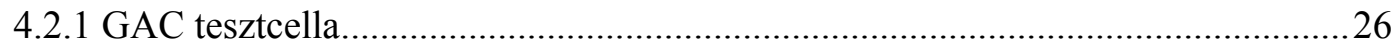

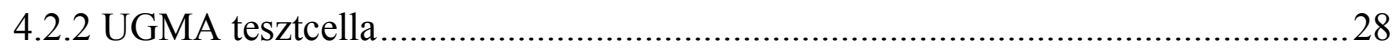

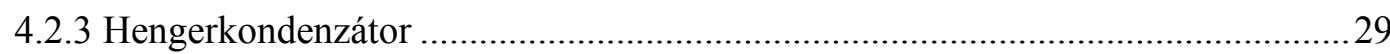

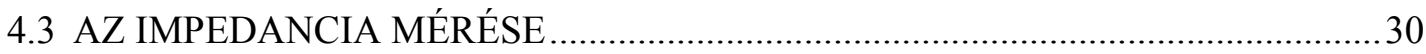

4.4 A SZÁMÍTOTT NEDVESSÉGTARTALOM MEGHATÁROZÁSA ......................... 32

4.5 A MÉRÉSI ÖSSZEÁLLÍTÁSOK ÉS A MÉRÉSEK MENETE .................................. 33

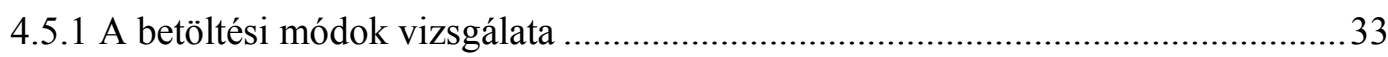

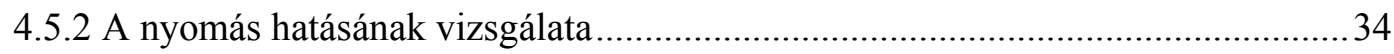

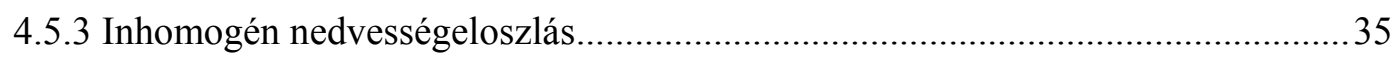

4.5.3.1 A gabonaszemeken belüli egyenlőtlen nedvességeloszlás vizsgálata ................................ 36

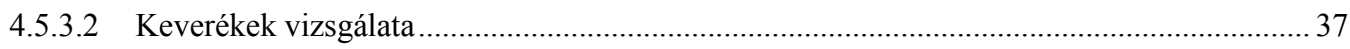

4.6 AZ ARGAND GÖRBE PARAMÉTEREI .......................................................... 40

4.7 DIELEKTROMOS POLARIZÁCIÓ FELSŐ HATÁRÁNAK BECSLÉSE ...............42

5 EREDMÉNYEK........................................................................................ 45

5.1 A DIELEKTROMOS SPEKTRUM TULAJDONSÁGAI 100 MHZ ALATT...........45

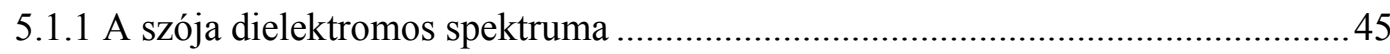

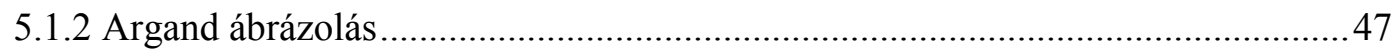

5.2 AZ LLL SÜRÜSÉGKORREKCIÓ MÜKÖDÉSE 100 MHZ ALATT.......................50

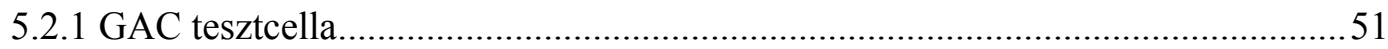

5.2.1.1 Az LLL sürüségkorrekció és a betöltések vizsgálata........................................................51

5.2.1.2 Az LLL sürüségkorrekció és a nyomás vizsgálata ..................................................... 51

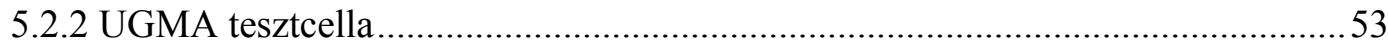

5.2.2.1 Az LLL sürüségkorrekció és a betöltések vizsgálata.........................................................53

5.2.2.2 Az LLL sürüségkorrekció és a nyomás vizsgálata .......................................................... 55 


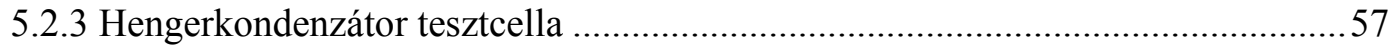

5.2.3.1 Az LLL sürüségkorrekció és a betöltések vizsgálata...............................................................57

5.2.3.2 Az LLL sürüségkorrekció és a nyomás vizsgálata ................................................................5

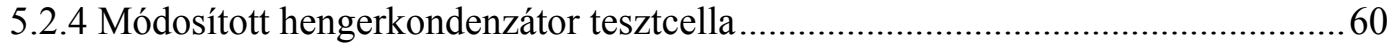

5.2.4.1 Az LLL sürűségkorrekció és a betöltések vizsgálata............................................................... 60

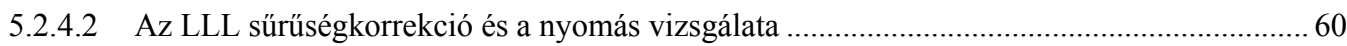

5.3 DIELEKTROMOS SPEKTRUMOK NYOMÁSFÜGGÉSE ..................................62

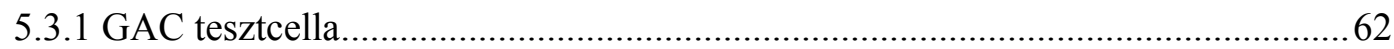

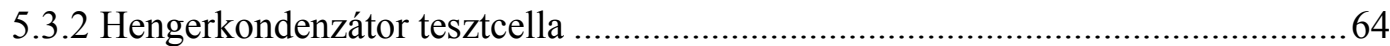

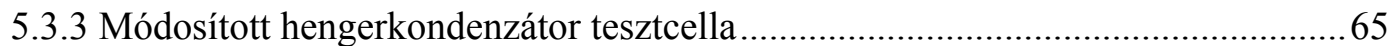

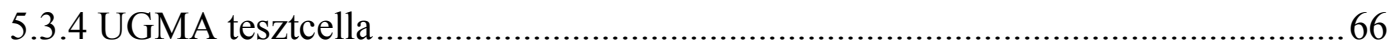

5.4 A TERHELÉS HATÁSA AZ ARGAND ÁBRÁKON .............................................. 70

5.5 MINTÁN BELÜLI EGYENLÖTLEN NEDVESSÉGELOSZLÁS ............................74

5.5.1 Gabonaszemeken belüli egyenlőtlen nedvességeloszlás ...................................74

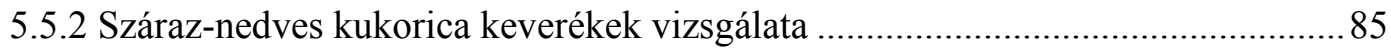

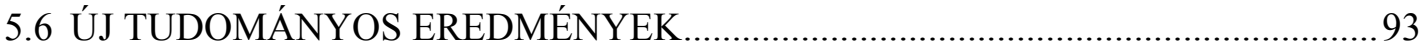

6 KÖVETKEZTETÉSEK ÉS JAVASLATOK_.........................................95

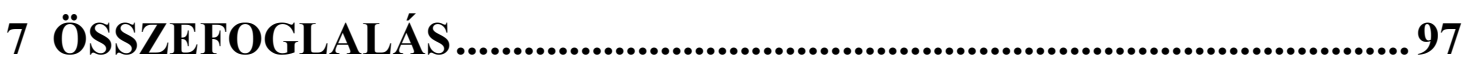

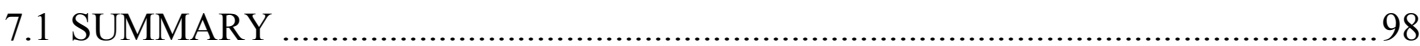

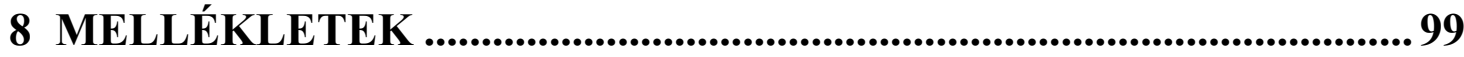

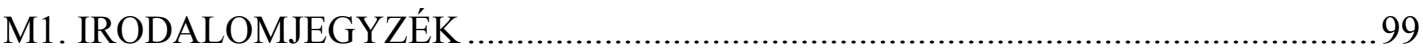

M2. relatív dielektromos állandó FELSÖ HATÁR SZÁMOLÁSA ................................ 107

M3. NYOMÁS HATÁSA AZ ARGAND GÖRBÉKRE............................................... 110 



\section{BEVEZETÉS}

A nedvességtartalom az egyik legfontosabb minőségi jellemzője a szemesterményeknek, amelytől a gabona biztonságos tárolása és kereskedelmi értéke függ. A gépesített betakarítás során a szemestermények általában a tárolási nedvességtartalomnál nedvesebb állapotban kerülnek betakarításra, ezért tárolási technológiájukban jelentős szerepet kapott a szárítás. A szárítók szabályozásának pontosságát igen sok tényező befolyásolja. A szabályozási hiba jelentős része a termény nedvességtartalmának mérési pontatlanságából adódik. Ha a gabona nem eléggé száraz mikrobiológia folyamatok, romlási gócok alakulhatnak ki, a túlszárítással pedig a termény mechanikai tulajdonságai romlanak. Bár a gabona nedvességmérésnek már közel 100 éves múltja van, de még mindig számos megoldatlan kérdés nehezíti a pontos nedvességmérők megalkotását. A nedvességtartalom meghatározásának két lehetséges módszere van, a közvetlen és a közvetett. A közvetlen nedvességmérési eljárások közös jellemzője, hogy az anyag nedvességtartalmának meghatározásához eltávolítják a víztartalmat. A közvetett mérési eljárások a vizsgált anyagnak a nedvességtartalomtól lehetőleg egyértelmüen függő, jól mérhető tulajdonságát használják fel, mint például a villamos vezetőképesség, a relatív permittivitás, a hővezető képesség, az abszorpciós képesség, az egyensúlyi légnedvesség. Ezek a mérési eljárások lényegesen gyorsabbak a közvetlen módszereknél, azonban egy olyan jellemzőt mérnek, ami nem csak a víztartalomtól függ. Ebből következik, hogy a mérési pontosság igen sok tényező függvénye. Léteznek olyan mérési eljárások, amelyeket e zavaró tényezők alig befolyásolnak (mikrohullámú, izotóptechnikai módszerek, mágneses magrezonancián alapuló eljárás), azonban viszonylagos bonyolultságuk, magas költségeik miatt az iparban nem terjedtek el. Az RF dielektromos módszerben kombinálódik a megfelelő pontosság és az egyes müszerek közötti szabványosítás lehetősége. Viszonylag egyszerü a kalibráció fejlesztése, és a gyártási költségek is elfogadhatók. A gyártók olyan megoldásokat keresnek, amelyek lehetőség szerint nem igényelnek drága technológiát. Ez az ok, amiért a legújabb kutatások ellenére, amelyek szerint a $100 \mathrm{MHz}$ feletti frekvenciatartományokban érdemes mérni, várhatóan még sokáig fognak alacsony frekvenciás berendezéseket használni. A dielektromos nedvességmérési módszer pontosságát befolyásoló tényezők a halmazsűrüség változás, a hőmérséklet, és az egyenlőtlen nedvességeloszlás a szemek között és a szemeken belül. A $100 \mathrm{MHz}$ alatti frekvenciatartományban különösen fontos a mérőfrekvencia körültekintő megválasztása.

A minták közötti sürüségkülönbségekből adódó nedvességmérési hibák oka, hogy a dielektromos tulajdonságok alapvetően térfogat alapúak, míg gabona nedves bázisra vonatkoztatott nedvességtartalma tömegalapú (a víz tömege a gabonában osztva a nedves gabona tömegével). Az on-line nedvességmérés egyik legnagyobb kihívása a sürüségkülönbségek miatt van, hiszen a minta 
betöltése vagy a mérőcellában lévő gabonahalmaz terhelése ellenőrizhetetlen, emiatt nehéz pontosan meghatározni a tényleges sürüségkülönbségeket. A gabona nedvességmérési gyakorlatban elterjedt Landau-Lifshitz, Looyenga sürüségkorrekció alkalmazásával a halmaztömörödöttségek változásából adódó hiba jól korrigálható $100 \mathrm{MHz}$ felett. Olyan kutatást még nem folytattak, amely a sürüségkorrekció alkalmazhatóságát vizsgálja a nyomás hatásának korrigálására, különböző tesztcella kialakításoknál, 100 MHz-nél kisebb frekvenciákon, ezért ez lett vizsgálataim egyik tárgya. Dolgozatomban megvizsgáltam a nyomás dielektromos jellemzőkre gyakorolt hatását.

Inhomogén nedvességeloszlás létrejöhet: a szemeken belül, szárítás hatására vagy száraz és nedves gabonaszemek keveredésével, a szemek között. A frissen szárított gabonaminta nedvességtartalmát pontosan nehéz mérni. A dielektromos elven müködő nedvességmérők köztudottan alábecsülik a kiegyenlítetlen minta nedvességtartalmát, mert ezek a müszerek a gabonaszemek külső rétegének nedvességtartalmára érzékenyek. (Zimmerman 1976, Bye 1986, Grain Handler USA, 2004.) Így a minta kiegyenlítődés után mért nedvességtartalma várhatóan nagyobb lesz, mint előtte. Ez a jelenség száraz és nedves kukorica keverékeknél is hasonlóan jelentkezik. Dolgozatomban megvizsgáltam az inhomogén nedvességeloszlás hatását kukorica minták dielektromos jellemzőire $100 \mathrm{MHz}$ alatt. Módszereket dolgoztam ki a szárított és a keverék minták kiegyenlítődött és inhomogén nedvességeloszlású állapotának szétválasztására.

A $100 \mathrm{MHz}$ alatti frekvenciákon a gabonák dielektromos spektrumaiban két vezetési hatás figyelhető meg: az elektród polarizáció és a Maxwell-Wagner relaxáció, melyek viselkedése függ a gabona nedvességtartalmától, a tesztcella kialakítástól, a halmaztömörödöttségtől és az inhomogén nedvességeloszlástól. Munkámban e két hatás dielektromos spektrumra gyakorolt hatását és ezek változását vizsgáltam meg a különböző zavaró tényezők függvényében. 


\section{IRODALMI ÁTTEKINTÉS}

Ebben a fejezetben a gabona nedvességmérés gyakorlatát és elméleti hátterét foglaltam össze, amely felhasználásával állítottam fel a kutatásom céljait.

\subsection{A NEDVESSÉGMÉRÉS GYAKORLATA}

A gabona nedvességtartalma az egyik legfontosabb minőségi jellemző, amely meghatározza a gabona eltarthatóságát és az árát. A gabona tárolásának kezdetén fontos a gabona nedvességtartalmának megfelelő szintre való beállítása, hogy a romlási folyamatokat megelőzzék. A gabona nedvességtartalma csökkenthető természetes száradással, vagy mesterségesen, szárítóberendezéssel. A mesterséges szárítás energiaigényes, így a gabona túlszárítása a minőségre való rossz hatása mellett a költség miatt is kerülendő.

A nedvességtartalmat a mintában lévő víz tömegének százalékos értékeként határozzák meg. Használatos a száraz és a nedves bázisra vonatkoztatott nedvességtartalom. A jelenlegi gyakorlatnak megfelelően a dolgozatomban a nedves bázisra vonatkoztatott nedvességet használtam, amely az (1) összefüggéssel adható meg (MSZ6367/3-83 1983, Wilhelm et al. 2004):

$$
M_{n}=\frac{m_{v i z}}{m_{\min t a}} \cdot 100
$$

ahol $\mathrm{M}_{\mathrm{n}}$ a nedves bázisra vonatkoztatott nedvességtartalom, $\mathrm{m}_{\mathrm{víz}}$ a gabonában lévő víz tömege, és $\mathrm{m}_{\text {minta }}$ a minta tömege. A magyar szabvány szerint a nedvességtartalom mértékegysége a $\%(\mathrm{~m} / \mathrm{m})$, dolgozatomban a nemzetközileg használt mértékegységet a \%-ot használtam. A nedvességtartalom jelölésére a továbbiakban az M-et fogom használni.

\subsubsection{Szemestermények nedvességmérése}

Az optimális gabonanedvesség beállításához, fontos egy megbízható nedvességmérési technika, amely a szárítás folyamán, vagy a szárítás elött és után megfelelő eredményt szolgáltat. A kereskedelemben a gabona nedvességtartalmának ármeghatározó szerepe van, mivel a vevő nem a vízért akar fizetni. Ebben az esetben a gabona hőmérséklete és állapota kiegyenlített, így a nedvességmérést kevesebb zavaró tényező befolyásolja, viszont a pontossággal támasztott követelmények igen szigorúak (Hoffman et al. 1976).

A gabona nedvességtartalmának a világon elterjedt referencia mérési módszere a szárítószekrényes mérés. A szárítószekrényes mérés lényege a minta szárítása súlyállandóságig, miközben az lead minden nedvességet. A minta szárítás előtti és utáni tömege ismeretében a 
nedvességtartalom meghatározható. A mérési eljárás az egész világon különböző. Az ok, hogy a gabona szárítása során nem csak a víz távozik, hanem egyéb illó anyagok is. Másrészt a gabona tulajdonságai miatt szárítással nagyon nehéz a víz teljes eltávolítása. Továbbá nem csak a módszer, hanem az eredmények is mutatnak kismértékü különbséget, amely akkor érdekes, amikor ezen eredmények alapján kalibrációt fejlesztenek (Burden 1998).

A szárítószekrényes mérés igen hosszadalmas és munkaigényes, ezért a mindennapi nedvességmérésekhez nem alkalmazzák. Az úgynevezett gyors nedvességmérő berendezéseket használják a gabona nedvességtartalmának meghatározására a gabona kezelése és kereskedelme során.

\subsubsection{Gyors nedvességmérő technológiák}

A 20. század elején felfedezték, hogy a gabona ellenállása és a nedvességtartalma korrelál egymással. Az ellenállás logaritmikusan növekszik a nedvességtartalom csökkenésével. Az első gabona nedvességmérők hengerek között átpréselt gabona ellenállásmérésén alapultak (Briggs 1908). A mai napig használnak ilyen müszereket, mert alacsony az áruk, de pontatlanságuk miatt nem elterjedtek, és ármeghatározáshoz nem használhatók.

A gyors nedvességmérésnek két technikája terjedt el. Az egyik az infravörös technika (NIR), amely igen pontos eredményt szolgáltat, de igen drága. Emellett nem alkalmas például a napraforgó nedvességtartalmának mérésére. A másik nehézség ezzel a módszerrel, hogy összetettsége miatt nagyon nehézkes az egyes berendezések eredményeinek összehangolása (Büchmann et al. 1995, Cowe et al. 1995, Hardy et al. 1995, Shenk et al. 1995).

Ettől eltérő, de szintén elterjedt technika a dielektromos tulajdonságokon alapul. Ezek a berendezések általában kevésbé pontosak, mint az infravörös nedvességmérők, viszont minden gabonafajta mérésére alkalmasak. A technológiájuk egyszerűsége miatt a berendezések ára kedvezőbb, és az egyéni mérőberendezések eredményeinek az összehangolása is egyszerübb (Funk 1998). Az utóbbi 60 évben a dielektromos elven működő nedvességmérők váltak dominánssá a gabonakereskedelemben (Nelson 1977, Nelson 1991).

A dielektromos elven müködő berendezések különböznek az alkalmazott frekvencia nagyságában. A legelterjedtebb berendezések a $20 \mathrm{MHz}$ frekvencia körüli tartományban müködnek. Mikrohullámú tartományban müködő berendezéseket alkalmaznak nagymennyiségü áramló gabona nedvességmonitorozására. A mikrohullámú frekvencia előnye, hogy lehetséges sürüségfüggetlen kalibrációk létrehozása, ezért alkalmas áramló gabonák mérésénél, ahol nem lehetséges a pontos halmazsürüség mérése. A hátránya, hogy a mikrohullámú frekvenciákon a kötött víznek már nincs hozzájárulása a permittivitáshoz, így csak olyan nedvességű gabonák mérhetők, amelyek a kötött vizen kívül tartalmaznak szabad vizet (Sembery et al. 2001). 
Az utóbbi években jelentek meg a $100 \mathrm{MHz}$ feletti frekvenciatartományban müködő nedvességmérők, amelyek a USDA-GIPSA által fejlesztett ún. UGMA (Unified Grain Moisture Algorithm - Egyesített Gabona Nedvességmérési Algoritmus) módszeren alapulnak (Funk et al. 2012). Ezen mérők pontossága és megfelelő ára miatt, 2012-től az Egyesült Államokban csak e nedvességmérők használata engedélyezett az exportra szánt gabona nedvességtartalmának meghatározásához (USDA-GIPSA 2012).

\subsubsection{Zavaró hatások}

\subsubsection{Sürüség}

A dielektromos gabona nedvességmérés eredményét a gyakorlatban számos zavaró hatás befolyásolja. A legjelentősebb a gabona halmazsürüségének változékonysága, amely a különböző betöltések hatására jön létre. Ennek a hatásnak az alapja, hogy a relatív dielektromos állandó, amely a nedvességmérési eredményt határozza meg, a tesztcellában lévő víz abszolút mennyiségétöl függ, viszont a nedvességtartalom a relatív vízmennyiségtől a minta tömegéhez képest (Nelson 1983).

E hibaforrás kiküszöbölésére a gyártók különböző stratégiákat használnak. A legegyszerübb és legkevésbé hatékony, hogy feltételeznek egy általános sürüséget minden gabonára. Ezek az úgynevezett "térfogatos" nedvességmérők érzékelik a meghatározott térfogatú gabona dielektromos tulajdonságát anélkül, hogy a minta tömegét megmérnék, és figyelmen kívül hagyják az ez által a nedvességtartalom meghatározásában okozott hibát. A második, valamivel jobb megközelítés, amikor egy olyan állandó tömegü minta dielektromos karakterisztikáját mérik, melynek a térfogata kisebb, mint a tesztcelláé. Ez utóbbi megoldással nagyobb pontosság érhető el, de mivel a sürüség és a relatív dielektromos állandó között nem lineáris a kapcsolat, ezért a korrekciók ellenére ezek a nedvességmérők is rendszeres hibát adnak (Funk 1990, Trabelsi et al. 1998, Funk 1999, Funk et al. 2007). A kifinomultabb berendezésekben a dielektromos tesztcellát állandó térfogatú mintával töltik meg és megmérik a minta tömegét is. Ez lehetővé teszi, hogy matematikai sürűségkorrekciót alkalmazzanak, azaz optimalizálják a nedvességmérő pontosságát nagyobb mintasürüség tartományban (Nelson 1981). Ezek ellenére a nedves gabonaminta magas nedvességtartalma erősen csökkenti a nedvességmérés pontosságát (Nelson 1977, Nelson 1978, Funk 2001).

A sürüség hatása a dielektromos tulajdonságokra még összetettebbé válik, amikor a vezetőképesség, az elektród polarizáció, a Maxwell-Wagner relaxáció hatását és a mérési frekvenciát is figyelembe vesszük. Funk 2001-ben végzett kutatásában megmutatta, hogy a vezetési hatások nagy szerepet játszanak gabona nedvességmérésben $100 \mathrm{MHz}$ alatt. $\mathrm{Az}$ on-line nedvességmérő rendszerekben, amikor a tesztcellán keresztülfolyik a gabona, ez még nagyobb kihívást jelent, mivel a minta sürüségét ebben az esetben több különböző hatás befolyásolja, mint 
például a mérendő mintára nehezedő gabona réteg nyomása vagy a vibráció a kombájnon (Funk 2001).

A mikrohullámú frekvenciatartományban, mivel a vezetési hatások elhanyagolhatók, lehetséges sürüségfüggetlen kalibrációk létrehozása. Ennek az alapja, hogy a relatív dielektromos állandó és a veszteségi tényező bizonyos kifejezése jól korrelál a nedvességtartalommal (Kraszewski et al. 1999, Trabelsi et al. 2007, Trabelsi et al. 2008).

\subsubsection{Hőmérséklet}

A relatív dielektromos állandó függ a hőmérséklettől, ezért a mért nedvességtartalom jelentősen eltérhet a ténylegestől, amennyiben a minta hőmérséklete különbözik a kalibrációban alkalmazott minták hőmérsékletétől, és nem alkalmaznak hőmérséklet korrekciót. A nedvességmérési hiba megközelítően $0,1 \% /{ }^{\circ} \mathrm{C}$. A hőmérséklet korrekció egy matematikai összefüggés, amellyel a nedvességmérési eredmény korrigálható. A relatív dielektromos állandó hőmérsékletfüggése nem lineáris széles hőmérséklettartományban, viszont a szobahőmérséklethez közeli tartományban a lineáris hőmérséklet korrekció elegendő. A hőmérséklet korrekciós tényező természetesen függ a mérőfrekvenciától, a gabonafajtól és bizonyos gabonák esetében a nedvességtartalomtól (Jones 1978, Nelson 1981, Lawrence et al. 1990, Trabelsi et al. 2006). A fagypont alatti nedvességmérés csak alacsony nedvességtartalmú minták esetén lehetséges, de akár mínusz $20^{\circ} \mathrm{C}$-ig (Meszaros et al. 2005).

\subsubsection{Beltartalom}

A becsült nedvességet a gabona beltartalma is befolyásolhatja, amely a minta növekedési körülményeitől és fajtájától függ. Egyik legjelentősebb példa erre a kukorica, amely esetén a korai fagy vagy szárazság miatt nem fejlődik ki táplálószövet és a szem sürűsége rendkívül alacsony marad. Ez a nedvességmérésben a nedvesség jelentős alulbecslését eredményezi. Szója esetében korrelációt figyeltek meg a nedvességmérési hiba és az olajtartalom között (Brenner et al. 2011).

A nedvességmérési eredményekre jelentősen hat a mintában lévő törött szemek aránya is. $\mathrm{E}$ hatás kiküszöbölése érdekében a mérendő mintából, megfelelő szabványos szitával, el kell távolítani a törött szemeket (Hemeda et al. 1982, Federal Grain Inspection Service 1997).

\subsubsection{Szemeken belüli egyenlőtlen nedvességeloszlás}

A gabonaszemeken belüli egyenlötlen nedvességeloszlás kétféle módon jöhet létre. Az egyik, amikor a gabonaszemeket kívülröl éri víz például eső, páralecsapódás vagy szándékos visszanedvesítés. A másik ennek ellentettje, mikor a gabona intenzív száradásnak van kitéve. 
Mindkét esetben a gabonának azt az állapotát értjük, amikor még nem volt elegendő idő a nedvesség kiegyenlítődésére.

A betakarított kukorica biztonságos tárolási nedvességtartalomra szárítása okozza a termelök egyik legjelentősebb kiadását. Ezt a költséget a szárítási folyamat on-line nedvességmérésével lehet csökkenteni. A szárítási folyamat közben a nedvességmérés pontatlanságának az egyik legjelentősebb oka a kukoricaszemeken belüli egyenlőtlen nedvességeloszlás (Montross et al. 1999, Kocsis et al. 2011).

Egy frissen szárított gabonaminta nedvességtartalmát pontosan nehéz mérni. Ha a mérésre közvetlenül a szárítóból való kivétel után kerül sor, a pontatlan hőmérsékletmérés is okozhat jelentős hibát. Ha a mintát engedjük mérés előtt szobahőmérsékletre lehülni, ez az idő nem elég a magon belüli inhomogén nedvességeloszlás kiegyenlítődésére, így a szemek belseje nedvesebb maradhat, mint a külső része, amelyet az 1. ábra szemléltet (Thorpe 1981).

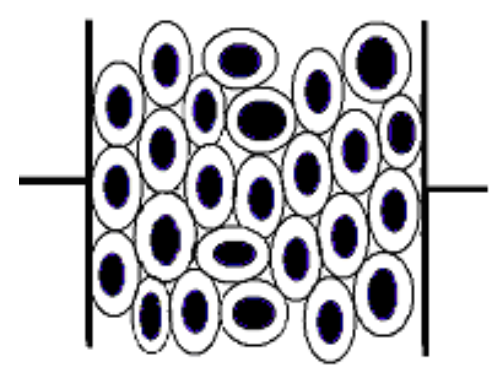

1. ábra Inhomogén nedvességeloszlás magon belül, kapacitív mérőcellában

Több tudományos cikk is foglalkozik az egyenlötlen nedvességeloszlás hatásaival, amelyek csak a hatás jelenlétére és a kiegyenlítés idejére vonatkoznak (Zimmerman 1976, Bye 1986). Ezekből megtudható, hogy a dielektromos elven működő nedvességmérők köztudottan alábecsülik a kiegyenlítetlen minta nedvességtartalmát. Így a minta kiegyenlítődés után mért nedvességtartalma várhatóan nagyobb, mint előtte. Ezt a jelenséget az angol nyelvü irodalomban "rebound"-hatásnak nevezik (Friesen et al. 1988). A nedvesség kiegyenlítődés miatt jelentkező számított nedvességtartalom különbség egyes magoknál néhány nedvességszázalék is lehet (Funk 2001). A gabonatermelők kompenzálás végett a nedvességmérők által kijelzett nedvességnél szárazabbra szárítják a gabonát, ami amúgy nem lenne szükséges. Így ezáltal a szárításban többlet költség jelentkezik. A nedvesség kiegyenlítődés jelenségének mélyebb ismerete nagyobb profitot eredményezhet a gabonaforgalmazóknak (Hemeda et al. 1982, Sokhansanj et al. 1988, Trabelsi et al. 2007). 


\subsubsection{Keverékek}

Nedves és száraz gabona keveredése többféle okból történhet. A leggyakoribb eset a mesterséges keverés. A kukorica nedvességtartalmát pontosan mérni egyaránt kihívást jelent termelőnek, forgalmazónak és a nedvességmérőket gyártó cégeknek. A gabona felvásárlók a gabonáért kevesebbet fizetnek a termelőknek, ha annak nedvességtartalma nagyobb, mint az úgynevezett piaci nedvességtartalom, amely az Egyesült Amerikai Államokban például kukorica esetén 15,0-15,5 \% közötti érték. Ennek az az oka, hogy a tápértéket a száraz anyagra vonatkoztatják, azaz ugyanakkora tömegü, de nedvesebb kukoricában kevesebb a tápérték, mint ugyanannyi szárazabb gabonában. Másrészről a nedves kukoricával további költségek jelentkeznek, hiszen a biztonságos tároláshoz le kell szárítani 13 \% nedvességtartalom alá ahhoz, hogy elkerüljék a mikrobiológiai és a kártevők miatt létrejövő romlást (Evans 1982). A termelők ugyancsak nem járnak jól, ha kukoricájuk kisebb nedvességtartalmú, mint a piacon elvárt, hiszen így alacsonyabb árat kapnak érte. Ezen okok miatt hatalmas a nyomás az eladókon, hogy terményüket a piaci nedvességtartalomhoz közeli értéken adják el. Másrészről ugyanez a piaci korlát hatalmas probléma azoknak, akiknek tárolniuk kell a kukoricát (Funk et al. 1996, Funk 1997).

Az Amerikai Egyesült Államokban a gabona visszanedvesítése illegális a gabonakereskedelemben, ezért termelők közvetlenül nem módosíthatják az eladásra szánt gabona nedvességtartalmát. Ehelyett a friss betakarításból származó, nedves kukoricát kevernek a tárolt, száraz gabonához. A nyereség maximalizálásához a keverék nedvességtartalmának minél jobban meg kell közelítenie a piaci, elvárt értéket. A megfelelő száraz-nedves gabona keveréket előállítani nem egyszerü. Először is a száraz és nedves gabona arányát kell pontosan beállítani. A kiindulási gabonák és a keverék nedvességtartamát gyors nedvességmérőkkel, általában dielektromos elven müködő mérőberendezésekkel ellenőrzik. A gabona nedvességmérőket a már kiegyenlítődött nedvességű gabonákra kalibrálják, emiatt a száraz-nedves keverék mért nedvességtartalma pontatlanná válik (Bonifacio-Maghirang et al. 1997, Funk 1998).

A vevőnek érdekében áll, hogy megtudja keverék-e a vásárolt gabona. Ha a száraz-nedves gabonakeverék nem egyenletes, az összekeverés nem volt elég alapos, akkor a nedvesebb gócokban romlási folyamatok indulhatnak el, mivel itt kedvezőbb a környezet a mikrobáknak. Nagytömegü keverék gabona szállításakor, ha a kukorica halmazt egy egyszerü kifolyócsővel töltötték be a vagonba vagy hajóba, a nedves és száraz magok hajlamosak szétválni. Míg a nedvesebb szemek a beöntési vonal közelében maradnak, addig a szárazabb szemek könnyebb tömegük miatt messzebb gurulnak el. Az így kialakuló nedvesség különbség akár 30\%-os is lehet (Montross et al. 1999). A nem egyenletes keveredés miatt a kiegyenlítődés lassabban jön létre, és romlási vonalak ún. forró 
pontok alakulnak ki. Emellett a keverék gabonák minősége sok esetben rosszabb, mert tartalmazhat túlszárított gabonát (Zimmerman 1976, Bonifacio-Maghirang et al. 1997).

Számos tanulmány készült a gabonaminták nedvességtartalom eloszlásának vizsgálatára egyenáramú (DC) vezetőképességen alapuló kukoricaszem nedvességmérőkkel. Nelson és Lawrence (1990) szignifikáns különbséget mutatott ki a kukoricacsövek tetején és alján lévő szemek nedvességtartalma között. Számos megismételt mérés elvégzése után azt találták, hogy a kukoricacsövön lévő szemek nedvességtartalma közötti különbség elérheti a 7 \%-ot is, amennyiben a minta átlagos nedvességtartalma 23 \% körüli volt (Nelson et al. 1991). Maghirang és társai (1997) megvizsgálták a nedves-száraz kukorica keverék kiegyenlítődési sebességét. A keverékekben és a már kiegyenlítődött mintákban összehasonlították a penészgomba telepek növekedését. A tanulmány kimutatta, hogy a megfelelően összekevert nedves-száraz minta nedvesség kiegyenlítődése megtörténik az első 24 órában.

Számos módszert találtak arra, hogy a keverék mintákat azonosítsák. A legkézenfekvőbb az egy szem mérők alkalmazása. Ebben az esetben számos szem nedvességtartalmát kell egyenként megmérni, szárítószekrényes (Hart 1967) vagy vezetőképességen alapuló módszerrel (Martin et al. 1986, Pomeranz et al. 1986). Ezek a kutatások megmutatták, hogy a nedvességeloszlás egyértelmúen mutatja a minta keverék mivoltát (Nelson et al. 1991). A mai napig nem létezik viszont olyan alkalmazott módszer, amellyel a keverék minták könnyen azonosíthatóak.

\subsection{ELMÉLETI HÁTTÉR}

\subsubsection{Permittivitás}

A permittivitás, annak a mértéke, hogy mennyire hat az elektromos tér egy szigetelő anyagra, és az anyag mennyire hat az elektromos térre. A külső elektromos tér hatására a szigetelö anyagban töltések mozdulnak el, és a külső térrel ellentétes elektromos teret hoznak létre. Ez a hatás figyelhető meg a kondenzátor lemezei közé helyezett anyag esetén. Mivel az anyagban létrejött elektromos tér ellentétes irányú a külső elektromos térrel, ezért ez csökkenti a külső elektromos tér nagyságát. Emiatt a hatás miatt lehet a kondenzátor lemezeken nagyobb mennyiségű töltést felhalmozni, ha nagy permittivitású anyagot helyezünk a lemezek közé. Az elektromos tér csökkenése a következő képlettel (2) írható fel:

$$
E_{k}=\varepsilon_{r} \cdot E_{b}
$$

ahol $E_{b}$ a külső és az anyagban létrejövő elektromos tér eredője, $E_{k}$ a külső elektromos tér nagysága, $\varepsilon_{\mathrm{r}}$ az anyag relatív permittivitása. 
Ebben az esetben az anyagban energia tárolódik, amely a külső tér megszünte után lead. A részecskék visszaállnak eredeti állapotukba. A komplex permittivitás valós részét a tudományos gyakorlatban relatív dielektromos állandónak nevezik, és dolgozatomban is így használom.

A relatív dielektromos állandó mérése történhet kondenzátor alkalmazásával. Ebben az esetben szükséges a kapacitás mérése, és a relatív dielektromos állandó a (3) képlettel számolható:

$$
C=\varepsilon_{r} \cdot C_{0}
$$

ahol $\mathrm{C}$ a kondenzátor kapacitása abban az esetben, amikor tartalmazza a mérendő anyagot és $\mathrm{C}_{0} \mathrm{az}$ üres tesztcella kapacitása.

Ha a külső elektromos tér időben változó tér, akkor az anyag tulajdonsága miatt elektromos energia vesztesség figyelhető meg. Ennek az oka, hogy az anyagban létrejövő változás miatt, az anyag belső részecskéinek mozgása során hő keletkezik. Ezt használják ki a mikrohullámú melegítés során. Az anyag ezen tulajdonsága a permittivitás komplex számként való használatával és annak képzetes részével jellemezhető. A gyakorlatban a képzetes rész az energia megmaradás törvénye értelmében negatív. A permittivitás képzetes részének pozitív értékét a tudományos gyakorlatban veszteségi tényezőnek nevezik, és dolgozatomban is ekként fogom használni. A komplex permittivitás a következőképen (4) írható:

$$
\varepsilon^{*}=\varepsilon^{\prime}-j \cdot \varepsilon^{\prime \prime}
$$

ahol $\varepsilon^{*}$ a komplex permittivitás, $\varepsilon^{\prime}$ a permittivitás valós része és $\varepsilon^{\prime \prime}$ a permittivitás képzetes része. A veszteségi tényező komplex impedanciás méréssel, egy párhuzamos kapacitív és rezisztív áramköri modell segítségével az (5) képlettel számolható:

$$
\varepsilon^{\prime \prime}{ }_{r}=\frac{G}{2 \cdot \pi \cdot f \cdot C_{0}}
$$

ahol $\mathrm{G}$ a rezisztív komponens vezetőképessége, $\mathrm{C}_{0}$ az üres tesztcella kapacitása és $\mathrm{f}$ az alkalmazott mérési frekvencia (Hasted 1973a).

\subsubsection{A permittivitás frekvencia függése}

A permittivitás értéke változik a frekvenciával. Ennek oka az anyag belső szerkezében keresendő. A permittivitásért több mechanizmus is felelős, ahogy azt a 2. ábra is mutatja. 


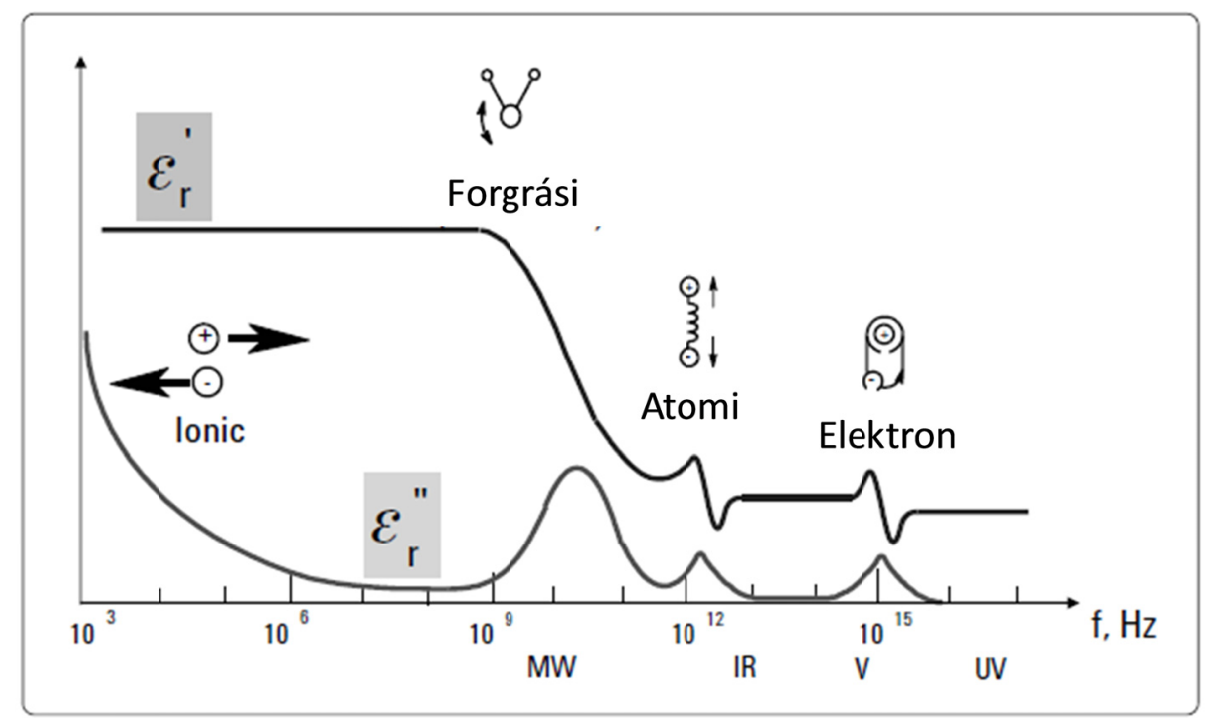

2. ábra Az anyag dielektromos tulajdonsága a frekvencia függvényében (forrás: Agilent

Technologies 2006)

A dipólus orientáció és az ionos vezetés a domináns az időben állandótól a mikrohullámú frekvenciatartományig. Az atomi és elektron mechanizmusoknak relatív kicsi a hozzájárulásuk a relatív dielektromos állandóhoz a mikrohullámú tartományban és értékük állandó. Minden dielektromos mechanizmusnak van egy relaxációs frekvenciája. Ahogy a frekvencia növekszik, a lassabb mechanizmusok hozzájárulása megszünik, és gyorsabb mechanizmusok járulnak hozzá a relatív dielektromos állandóhoz. Ez a frekvenciafüggés természetesen anyagfüggő. Az atomi és elektron átmeneteket rezonancia jelenségeknek, az ionos és forgásit relaxációs jelenségnek nevezzük (von Hippel 1995).

\subsubsection{Orientációs polarizáció}

A molekulákon, a nem egyenletes töltéseloszlás miatt, külső elektromos tér hatására forgatónyomaték ébred, amely annak elfordulását, a térrel megegyező irányú orientációját eredményezi. Természetesen, a hőmozgás és egyéb az anyagon belüli molekuláris erők miatt, ez az orientáció nem 100 \%-os. A külső tér megszünésével a molekulák ismételten teljesen rendezetlen állapotba kerülnek. A molekulák elfordulási készsége határozza meg a dielektromos hozzájárulásukat (Hasted 1973).

A komplex permittivitás (6), a relatív dielektromos állandó (7) és a veszteségi tényező (8) frekvencia függése az alábbi egyszerüsített, tapasztalati képletekkel írható le (Debye 1929):

$$
\varepsilon_{r}^{*}=\varepsilon_{r \infty}+\frac{\varepsilon_{r s}-\varepsilon_{r \infty}}{1+j \cdot \omega \cdot \tau_{r}}
$$




$$
\begin{aligned}
& \varepsilon_{r}^{\prime}=\varepsilon_{r \infty}+\frac{\varepsilon_{r s}-\varepsilon_{r \infty}}{1+j \cdot \omega^{2} \cdot \tau_{r}{ }^{2}} \\
& \varepsilon^{\prime \prime}{ }_{r}=\frac{\left(\varepsilon_{r s}-\varepsilon_{r \infty}\right) \cdot \omega \cdot \tau_{r}}{1+j \cdot \omega^{2} \cdot \tau_{r}{ }^{2}}
\end{aligned}
$$

ahol $\varepsilon_{\mathrm{r} \infty}$ a relatív dielektromos állandó a végtelen nagy frekvencián, $\varepsilon_{\mathrm{rs}}$ a relatív dielektromos állandó nulla frekvenciánál, $\omega$ a körfrekvencia $(2 \cdot \pi \cdot f)$ és $\tau_{\mathrm{r}}$ a relaxációs időállandó:

$$
\tau_{r}=\frac{1}{2 \cdot \pi \cdot f_{r}}
$$

ahol $\mathrm{f}_{\mathrm{r}}$ a relaxációs frekvencia.

A 3. ábra a relatív dielektromos állandó és veszteségi tényező Debye-féle frekvencia függését mutatja:

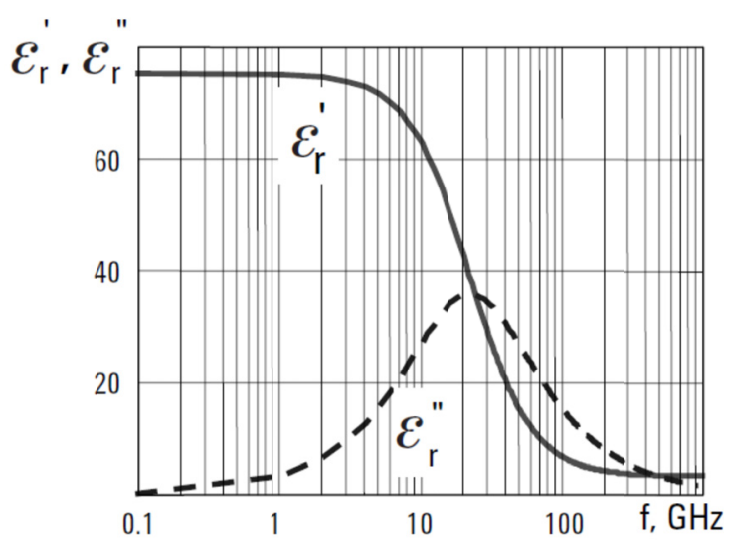

3. ábra Debye relaxáció a frekvencia függvényében (forrás: Agilent Technologies 2006)

A veszteségi tényező maximuma a (10) képlettel számolható:

$$
\varepsilon_{r \max }^{\prime \prime}=\frac{\varepsilon_{r s}-\varepsilon_{r \infty}}{2}
$$

\subsubsection{A vezetőképesség hozzájárulása a permittivitáshoz}

A veszteségi tényező két mechanizmusból tevődik össze. Az egyik a bipoláris molekulák forgásából származó tényleges dielektromos veszteség, a másik az anyag egyenáramú vezetőképességéből adódó, a frekvenciával fordítottan arányos összetevő. Így a veszteségi tényező $\left(\varepsilon^{\prime \prime}\right)$ a Maxwell egyenletekből levezethető és a következőképpen írható (11): 


$$
\varepsilon^{\prime \prime}=\varepsilon_{r d}{ }^{\prime \prime}+\frac{\delta}{\omega \cdot \varepsilon_{0}}
$$

ahol $\varepsilon^{\prime \prime}{ }_{\text {rd }}$ a dielektromos veszteség, $\delta$ vezetöképesség és $\omega$ a körfrekvencia.

Az ionos vezetés csak a veszteségi tényezőben játszik szerepet. Alacsony frekvenciákon a vezetés hatása fordítottan arányos a frekvenciával és $1 / f$ meredekségü egyenesként jelenik meg a veszteségi tényező spektrumában (Hasted 1973a).

\subsubsection{Felületi polarizáció}

Ha a töltéshordozók az anyagban elmozdulhatnak, de valami miatt a vándorlásuk akadályoztatott, mint például egy szemcsés vezető anyag nem vezető mátrixban, akkor külső térerősség hatására a szabad töltések a szemcsékben elmozdulnak, és a határfelületeken felhalmozódnak, ezzel csökkentve az eredő elektromos teret és az effektív relatív dielektromos állandót. Ezt nevezik Maxwell-Wagner effektusnak. Az effektus frekvenciafüggésének jellege megegyezik a dipólus relaxáció frekvenciafüggésével, ezért nehéz eldönteni egy relaxációs jelenségröl, mint a gabonák esetében, hogy kötött víz relaxációt tapasztalunk vagy MaxwellWagner hatást (von Hippel 1995a).

A Maxwell-Wagner relaxáció relaxációs frekvenciája számolható gömb részecskére egy adott mátrixban (12):

$$
f_{r}=\epsilon_{0} \cdot\left(\frac{\sigma_{1}+2 \cdot \sigma_{m}}{\varepsilon_{1}+2 \cdot \varepsilon_{m}}\right)
$$

ahol $\sigma_{1}$ a vezető részecske vezetőképessége, $\sigma_{\mathrm{m}}$ a mátrix vezetőképessége, $\varepsilon_{1}$ a vezető részecske relatív dielektromos állandója és $\varepsilon_{\mathrm{m}}$ a mátrix relatív dielektromos állandója (Russel et al. 1989). A képlet is mutatja, hogy a vezető részecskék vezetőképességével nő a relaxációs frekvencia.

A kilohertzes frekvenciatartományban igen jelentős lehet az elektród polarizációs hatás. Ez azért jön létre, mert az elektródákhoz vándorló töltések, amelyek lehetnek ionok vagy protonok, nem képesek a fém elektródba távozni, így egy elektromos kettősréteg jön létre a gabonában az elektród közelében lévő felületen. Ez a jelenség az egyenáramtól a kHz-es frekvenciatartományig jelentkezik, és hatása jóval nagyobb lehet, mint a dielektromos vagy a Maxwell-Wagner relaxáció hatása (Foster et al. 1989, Kuang et al. 1998, Klein et al. 2006, Emmert et al. 2011).

Grimnes et al. (2000) számolt be hasonló jelenségről. Véleményük szerint, az elektród polarizációs frekvenciatartományban a teljes minta-elektród rendszerben lévő vezetési hatások dominálják dielektromos spektrumot. A mintában a vezetés az ionok mozgása miatt jön létre. Funk (2001) feltételezése szerint ez valószínüleg “szivárgó” protonos vezetés. Az elektród felszínén és közelében a töltések mozgása, cseréje az ionok és az elektronok között történik. Ez a komplex 
elektro-kémiai reakció a diffúzió által korlátozott és valószínűleg erősen frekvenciafüggő. Az ilyen komplex rendszer nem modellezhető ideális ellenállásokkal és kapacitásokkal, mert inkább elektrolitnak tekinthetők, mint dielektrikumnak. Ez a jelenség egy konstans fázisú elemként (Constant Phase Element) jelentkezik, melynek képe az Argand ábrákon egy egyenes (Grimnes et al. 2000, Funk 2001).

\subsubsection{Keverék egyenletek és sürüségkorrekció}

A legtöbb esetben a mérni kívánt vagy mikrohullámú kezelést igénylő anyag nem homogén, hanem több különböző dielektromos tulajdonságokkal rendelkező anyag keveréke. Ez a helyzet az esetünkben vizsgált gabonákkal is, amelyek gabona magvak és levegő keveréke. Ezen dielektromos szempontból inhomogén anyagok eredő permittivitása valahol a legkisebb és a legnagyobb relatív dielektromos állandójú komponens értéke között van, de nem egyszerüen a komponensek permittivitásainak összege, hanem ennél jóval bonyolultabb összefüggés.

Számos kutatás folyt, elméleti és kísérleti módszerekkel, a dielektromos jellemzők és a minta sürüsége közötti kapcsolatot leírására. Számos keverék összefüggést és ezek hatékonyságát határozták meg különböző anyagokra (Hasted 1973b, Kraszewski 1977, Nelson et al. 1990, Nelson 1992, Nelson 1996, Hilhorst 1998).

A gabonák esetében egyértelműen a Landau és Lifshitz (1960), majd Looyenga (1965) által publikált keverékformula bizonyult a legeredményesebbnek (Nelson 1983a). Ebben az összefüggésben (13) nem játszik szerepet a részecskék formája és orientációja:

$$
\varepsilon^{\frac{1}{3}}=v_{1} \cdot \varepsilon_{1}^{\frac{1}{3}}+v_{2} \cdot \varepsilon_{2}^{\frac{1}{3}}
$$

ahol $\varepsilon$ a keverék permittivitása, $\varepsilon_{1}$ és $\varepsilon_{2}$ a komponensek permittivitása, $v_{1}$ és $v_{2}$ a komponensek relatív térkitöltése.

A nedvességmérés szempontjából nem közvetlenül a keverék formula hasznos. Ahogy azt már az előzőekben említettem, a nedvességmérés pontatlanságát leginkább a különböző betöltésekkor kialakuló különböző halmazsűrüség változékonysága eredményezheti. A dielektromos tulajdonságok és a térkitöltés között egyértelmü összefüggést nehéz megállapítani (Sembery 2002). Ennek oka, hogy a sürüségkülönbségek származhatnak a gabonaminta jellemzőiből és a gabona betöltési módjától. Azaz a minta halmazsürüsége függ a gabonamag sürüségétől, formájától, felületének jellemzőitől, mint az érdesség és a ragadósság, a tesztcella alakjától és térfogatától és a minta betöltési sebességétől (Hlynka et al. 1959). Különbözik a minta tömörödöttsége akkor is, ha a tesztcella rázkódásnak van kitéve, vagy nyomás alatt van (Nelson 1981, Trabelsi et al. 2007). Ezért Nelson a keverékformulát továbbfejlesztette, annak 
figyelembevételével, hogy a levegő relatív dielektromos állandója 1, létrehozott egy sürüség transzformációt (14a). Ha egy adott gabonaminta sürüsége és relatív dielektromos állandója ismert, akkor a relatív dielektromos állandó egy másik sürüségi állapotban a (14a) összefüggéssel kiszámolható (Nelson 1983b, Nelson 1992, Nelson 2005):

$$
\varepsilon_{2}=\left[\left(\varepsilon_{1}^{\frac{1}{3}}-1\right) \cdot \frac{\rho_{2}}{\rho_{1}}+1\right]^{3}
$$

ahol $\varepsilon_{2}$ a számolt relatív dielektromos állandó, $\varepsilon_{1}$ a mért relatív dielektromos állandó, $\rho_{1}$ a mért sürüség és $\rho_{2}$ egy tetszőleges gabonaminta sürüség.

Funk (2001) megállapította, hogy (14a) összefüggés rendkívül hatékonyan müködik mint sürüségkorrekció (14b), ha minden minta relatív dielektromos állandóját egy adott célsűrüségre transzformálja:

$$
\varepsilon_{d c}=\left[\left(\varepsilon^{\frac{1}{3}}-1\right) \cdot \frac{\rho_{0}}{\rho}+1\right]^{3}
$$

ahol $\varepsilon_{\mathrm{dc}}$ a sürüségkorrigált relatív dielektromos állandó, $\varepsilon$ a mért relatív dielektromos állandó, $\rho$ a mért sürüség és $\rho_{0}$ a célsürüség, amely $686 \mathrm{~kg} / \mathrm{m}^{3}$ volt. Mivel a tesztcella térfogata állandó, ezért a sürüségek helyett a minta tömegét és céltömeget használta $(580 \mathrm{~g})$. A sürüségkorrekció eredményességét 15 amerikai gabona fajtán, közte kukoricára és szójára is, bizonyította magas frekvencián mért relatív dielektromos állandók esetén. A sürüségkorrekció eredményességét a 4. ábra mutatja (Funk et al. 2007):
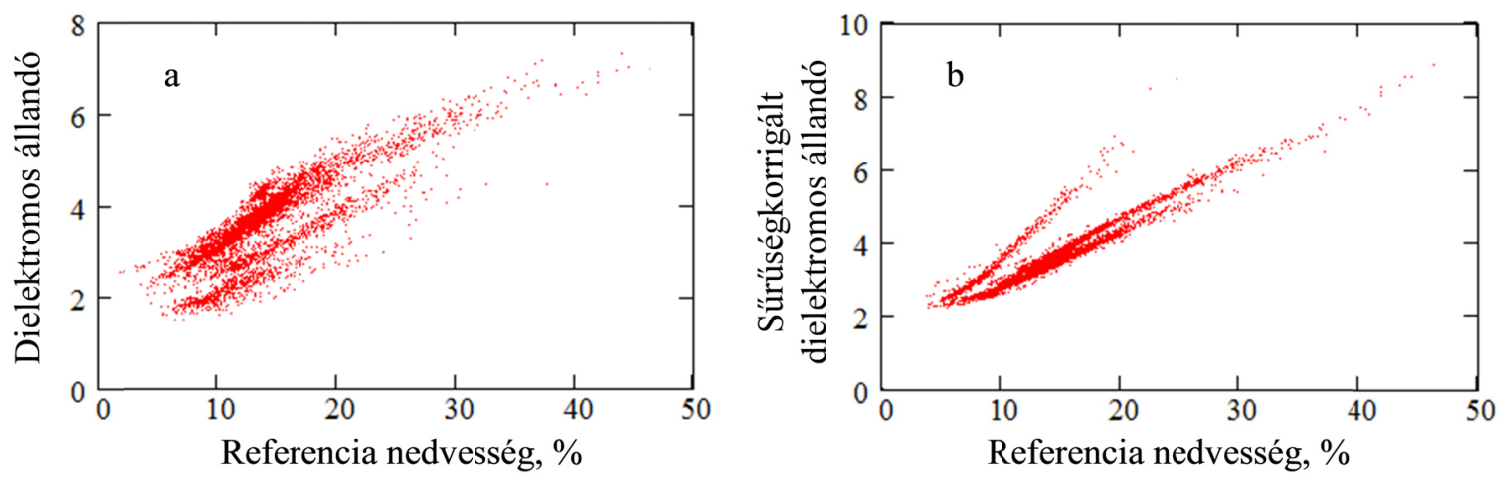

4. ábra A Landau-Lifshitz, Looyenga sürüségkorrekció hatása gabonamintákra; a: sürüségkorrekció nélkül, b: sürüségkorrekcióval 
A 4. ábra alapján az látható, hogy az Landau-Lifshitz, Looyenga sürüségkorrekció (14b) alkalmazásával a nedvességtartalom és a relatív dielektromos állandó közötti összefüggésben az adatok csoportokba rendeződnek bizonyos gabonacsoportok szerint.

Az 5. ábra a Landau-Lifshitz, Looyenga sürüségkorrekció müködését szemlélteti:

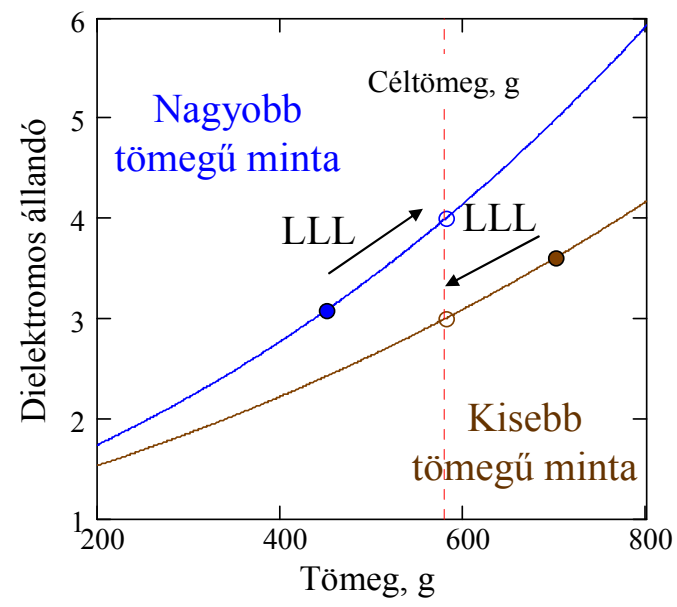

5. ábra A Landau-Lifshitz, Looyenga sürüségkorrekció müködésének szemléltetése

Látható, hogy az Landau-Lifshitz, Looyenga sürüségkorrekció a különböző minták relatív dielektromos állandóját egy adott célsürüséghez tartozó relatív dielektromos állandó értékére konvertálja. Ha a minta sürüsége nagyobb, mint a célsürüség, akkor a korrekciós egyenlet alkalmazása után számított relatív dielektromos állandó értéke kisebb lesz, mint a minta mért relatív dielektromos állandója. Ha a minta sürüsége kisebb, mint a célsürüség, akkor a korrigált relatív dielektromos állandóra nagyobb értéket kapunk, mint az eredetileg mért.

Munkámban a Landau-Lifshitz, Looyenga sürüségkorrekciót (14b) a továbbiakban LLL sürüségkorrekcióként használom.

\subsubsection{Gabonaszemek orientációja}

Nem gömbszimmetrikus gabonaszemek esetében a gabonaminta mérőcellába való betöltése nem csak a gabonahalmaz sürüségére van hatással, hanem a gabonaszemek orientációjára is. Az orientáció függ a gabona fizikai tulajdonságaitól, a tesztcellába való betöltés irányától és a betöltés sebességétől. A gabonaszemek orientációs tendenciája sok esetben nem figyelhető meg, de a nedvességmérésben szignifikáns különbséget okozhat. A tesztcella falára merőlegesen elhelyezkedő gabonaszemek nagyobb relatív dielektromos állandót eredményeznek, mint a tesztcella falával párhuzamosan elhelyezkedő gabonaszemek. Ebből kifolyólag egy minden irányban egyenletes valószínűséggel álló gabonaszemeket tartalmazó gabonamintánál magasabb nedvességmérési eredményt fogunk kapni egy olyan betöltésre, amelynek hatására a tesztcella falára merőlegesen 
álló gabonaszemek aránya nagyobb, és alacsonyabb nedvességmérési eredményt, ha a tesztcella falával párhuzamos szemek aránya növekszik meg. A gabonaszemek orientációs tendenciái önmagukban nem tesznek egy betöltést jobbá vagy rosszabbá, a mérési hiba akkor keletkezik, ha a betöltés módja változik, és nem történik korrekció ennek a hatásnak a korrigálására. Semelyik sürüségkorrekció nem alkalmas a betöltés változatosságának tökéletes korrigálására, mert az adott véletlenszerűen kialakuló mintahalmazban nem ismert a gabonaszemek irányának mértéke. Két betöltési mód között empirikusan meghatározható korrekció. A korrekció nedvességtartalom függő, de a legtöbb gabonafajtára lineáris (Gillay 2010).

\subsubsection{Gabonában lévő víz}

A víz szabad és kötött formákban van jelen a gabonában. A szabad víz, mely a mag makroés mikrokapillárisaiban helyezkedik el magas hőmérsékleten könnyen eltávolítható. A kémiailag kötött víz csak az anyag roncsolása után vonható el. A víz ezen formája körülbelül 5-6 \%-a gabona teljes tömegének (Serdyuk 2008). Mindezen kötött állapotokban a víztartalmak relatív dielektromos állandója különbözö, de minden esetben kisebb, mint a szabad vízé.

Sembery (1976) megállapította, hogy a természetes nedvességtartalmú és a mesterségesen nedvesített minták dielektromos tulajdonságaiban a nedvességkiegyenlítődés után nem tapasztalható számottevő különbség az általa vizsgált 50 kHz-50 MHz frekvenciatartományban.

\subsubsection{Argand diagramos ábrázolás}

A gabonák dielektromos tulajdonságainak leírására az RF frekvenciatartományban a publikációk általában táblázatban rögzítik vagy grafikonokkal ábrázolják az impedancia, a relatív dielektromos állandó, veszteségi tényező, veszteségi tangens és az ac vezetőképesség frekvencia vagy nedvességtartalom függését (Nelson et al. 1975, Nelson et al. 1976, Sembery et al. 1999, Géczi et al. 2002). Ezek az adatok és ábrázolás módok hasznosak voltak általános igazságok megállapítására, azonban nem adtak elég fizikai betekintést a minták közötti különbségek igazi természetéről.

A permittivitás valós és képzetes részének frekvencia függvényében történő viselkedését sok esetben jobban meg lehet figyelni a Cole-Cole vagy más néven Argand diagramokon. Ez esetben a permittivitás valós részét a vízszintes tengelyen, a képzetes részét a függőleges tengelyen ábrázoljuk. Az ábrázolás hátránya, hogy az egyes pontokhoz tartozó frekvencia nem látható (Witten Jr et al. 1975).

A Debye által leírt relaxáció az Argand diagramos ábrázolással 6. ábrán látható: 


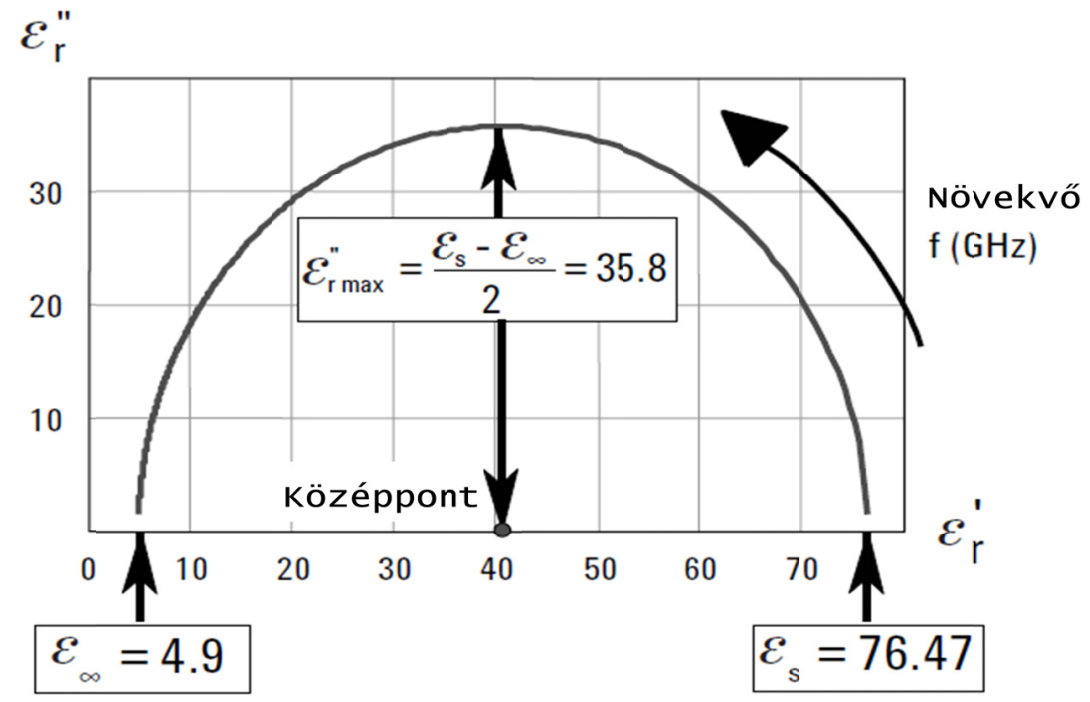

6. ábra Debye relaxáció Argand diagram (forrás: Agilent Technologies 2006)

A komplex permittivitás valós és képzetes része közötti összefüggés félkörívként jelenik meg. Abban az esetben, amikor egy relaxációs mechanizmus játszik szerepet, akkor a kör középpontja az x tengelyre esik. A pont, ahol a félkörív jobb oldalon metszi az x tengelyt, a statikus relatív dielektromos állandónak felel meg. A félkörív baloldali metszéspontja a relatív dielektromos állandó végtelen frekvencián vett értéke. A távolság a legkisebb és a legnagyobb frekvencián lévő metszéspontok között a relatív dielektromos állandó csökkenés, mely a relaxációs hatások miatt jön létre. A körív sugara, ebben az esetben a körív legfelsőbb pontjának a távolsága az x tengelytől a veszteségi tényező maximumának az értéke. A maximum y értékhez tartozó frekvencia a relaxációs frekvencia (Agilent Technologies 2006).

Számos tiszta folyadék dielektromos viselkedése jól követi a Debye összefüggést, de a legtöbb anyagnál nem egy relaxációs idő van, hanem a relaxációs idők valamilyen eloszlás szerint változnak. Ha például két, kellő mértékben különböző relaxációs frekvencia van jelen, akkor két körív jelenik meg az ábrán. Ha egy relaxációs mechanizmus van jelen, de valamilyen okból számos kis mértékben különböző frekvencián, akkor, a megjelenő körív középpontja az x-tengely alatt található. Az ilyen rendszereket sok esetben a (6) egyenlethez hasonló (15) empirikus egyenlet (Cole et al. 1941) írja le:

$$
\varepsilon_{r}^{*}=\varepsilon_{r \infty}+\frac{\varepsilon_{r s}-\varepsilon_{r \infty}}{1+(j \cdot \omega \cdot \tau)^{1-\alpha}}
$$

ahol $\alpha$ az időállandó eloszlásának a paramétere. (Megjegyzés: ez az $\alpha$ nem azonos a későbbiekben használt körív központi szögével.) A relaxációs idő eloszlási paraméter értéke 0 és 1 közé eshet és a relaxációs idő kiterjedését jellemzi. 


\subsubsection{Gabonaminták áramköri modellezése}

A gabonaminta viselkedését nem lehet elektromos térelmélettel leírni, hanem szükség van fenomenológiai leírásra, amin keresztül a gabona dielektromos tulajdonságai megérthetők. Az egyik legkézenfekvőbb lehetőség elektromos komponensek használatával modellezni a gabona dielektromos viselkedését.

A szabad víz és kötött víz relaxációs frekvenciája nagyobb frekvenciákon van, mint az általam vizsgált frekvenciatartomány. A kutatásom fókusza a Maxwell-Wagner relaxáció és az elektród polarizáció volt. Ezek modelljét és viselkedését az továbbiakban mutatom be.

A Maxwell-Wagner relaxáció és elektród polarizáció áramköri modellje a 7. ábrán látható:
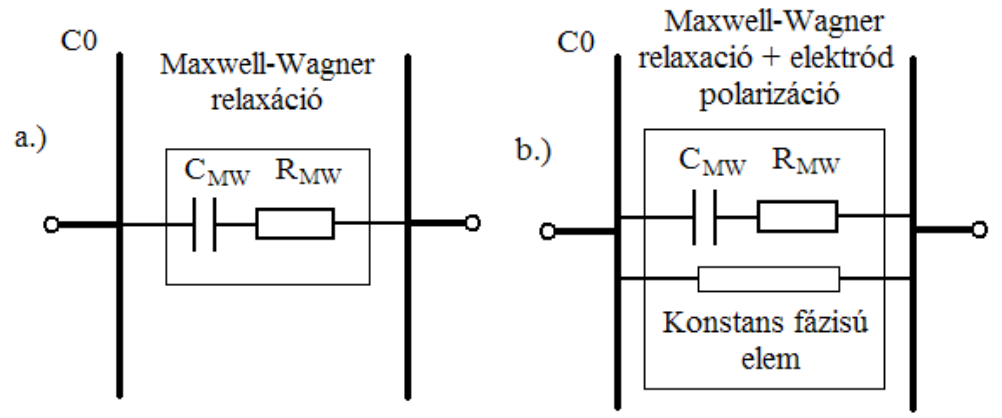

7. ábra a.) Maxwell-Wagner relaxációjának áramköri helyettesítő modellje egy $\mathrm{C}_{0}$ kapacitású kondenzátorban, b.) Elektród polarizáció és Maxwell-Wagner relaxáció áramköri helyettesítő modellje egy $\mathrm{C}_{0}$ kapacitású kondenzátorban

A Maxwell-Wagner relaxáció modellje a következőképpen (16) számolható a soros modell alapján:

$$
Z^{*}{ }_{M W}=R_{M W}+\frac{1}{j \cdot 2 \cdot \pi \cdot f \cdot C_{M W}}
$$

ahol $\mathrm{R}_{\mathrm{MW}}$ és $\mathrm{C}_{\mathrm{MW}}$ a Maxwell-Wagner relaxáció modelljének ellenállása és kapacitása, f a frekvencia. Mivel amit mérünk, azt modellezzük, így a mért impedancia egyenlő a modellezett impedanciával:

$$
Z^{*}{ }_{m}=Z^{*}{ }_{M W}
$$

ahol $Z_{\mathrm{m}}$ a mért impedancia és $Z_{\mathrm{MW}}$ a modellezett impedancia. A továbbiak egyszerübben írhatók, ha bevezetjük a mért komplex admittanciát $\left(\mathrm{Y}^{*}{ }_{\mathrm{m}}\right)$ :

$$
Y^{*}{ }_{m}=\frac{1}{Z_{m}^{*}}
$$

Így a relatív dielektromos állandó a következőképpen számolható: 


$$
\varepsilon^{\prime}=\frac{Y{ }^{\prime \prime} m}{2 * \pi * f * C_{0}}
$$

ahol $\mathrm{Y}^{\prime \prime}{ }_{\mathrm{m}}$ a mért admittancia képzetes része, $\mathrm{C}_{0}$ az üres kondenzátor kapacitása. A veszteségi tényező a következő képlettel számolható:

$$
\varepsilon^{\prime \prime}{ }_{r}=\frac{Y_{m}^{\prime}}{2 * \pi * f * C_{0}}
$$

ahol $\mathrm{Y}_{\mathrm{m}}^{\prime}$ a mért admittancia valós része. A relaxációs frekvencia $\left(\mathrm{f}_{\mathrm{m}}\right)$ az alábbi képlettel számolható:

$$
f_{r}=\frac{1}{R_{M W^{\prime}} C_{M W} \cdot 2 \cdot \pi}
$$

A csak az ábrázolás kedvéért $\mathrm{R}_{\mathrm{MW}}=10^{6} \mathrm{ohm}, \mathrm{C}_{\mathrm{MW}}=30 \mathrm{pF}$ és $\mathrm{C}_{0}=3 \mathrm{pF}$ tetszőleges értékekkel a szimuláció eredménye a 8 . ábrán látható:
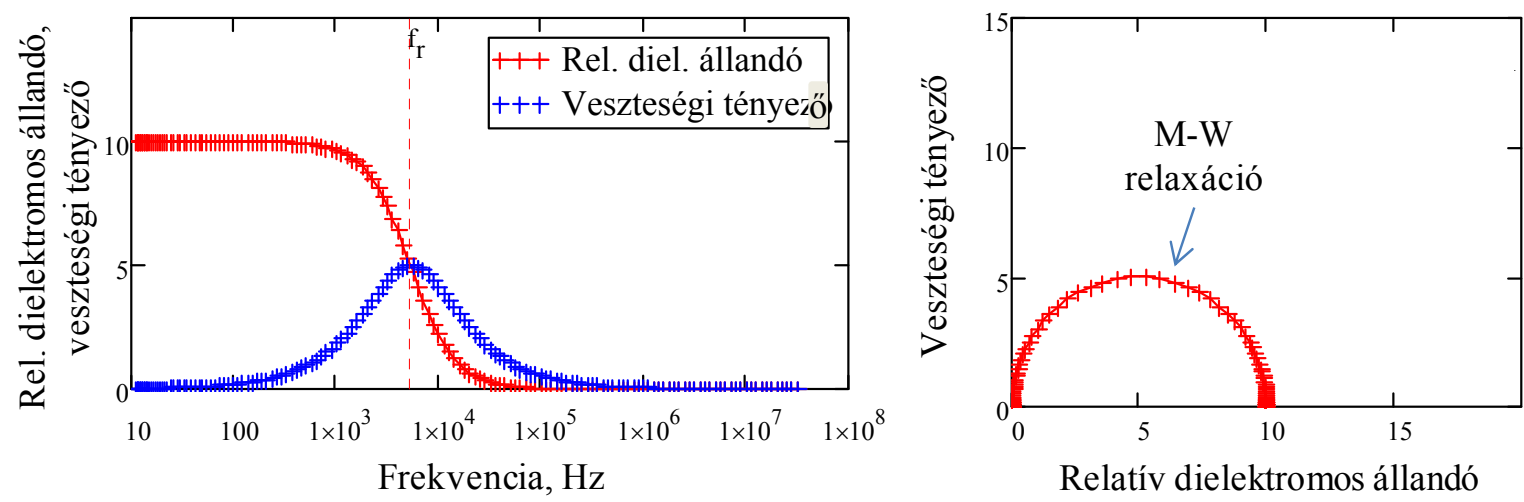

8. ábra A Maxwell-Wagner relaxáció szemléltetése a frekvencia függvényében és Argand diagramon (forrás: Gillay)

Az ábrán látható, hogy a Maxwell-Wagner relaxáció hasonló lefutást mutat, mint a dielektromos relaxáció, az egyetlen megfigyelhető különbség, hogy a végtelen frekvencián a dielektromos hozzájárulás nulla.

Az elektród polarizáció egy párhuzamosan kapcsolt konstans fázisú elemként vehető figyelembe az alábbi módon (22):

$$
Z^{*}{ }_{m}=Z^{*}{ }_{M W}-j \cdot Z_{e p} \cdot e^{j \cdot \theta_{e p}}
$$

ahol $Z_{\mathrm{ep}}$ elektród polarizáció miatt kialakuló impedancia (valós szám), $\Theta_{\mathrm{ep}}$ a fázistolás mértéke. Az ábrázoláshoz $Z_{\mathrm{ep}}=5 * 10^{8} \mathrm{ohm}$ és a $\Theta_{\mathrm{ep}}=\pi / 4$ tetszőleges értékkel, a (17-20) képleteket alkalmazva a szimuláció eredménye a 9. ábrán látható: 

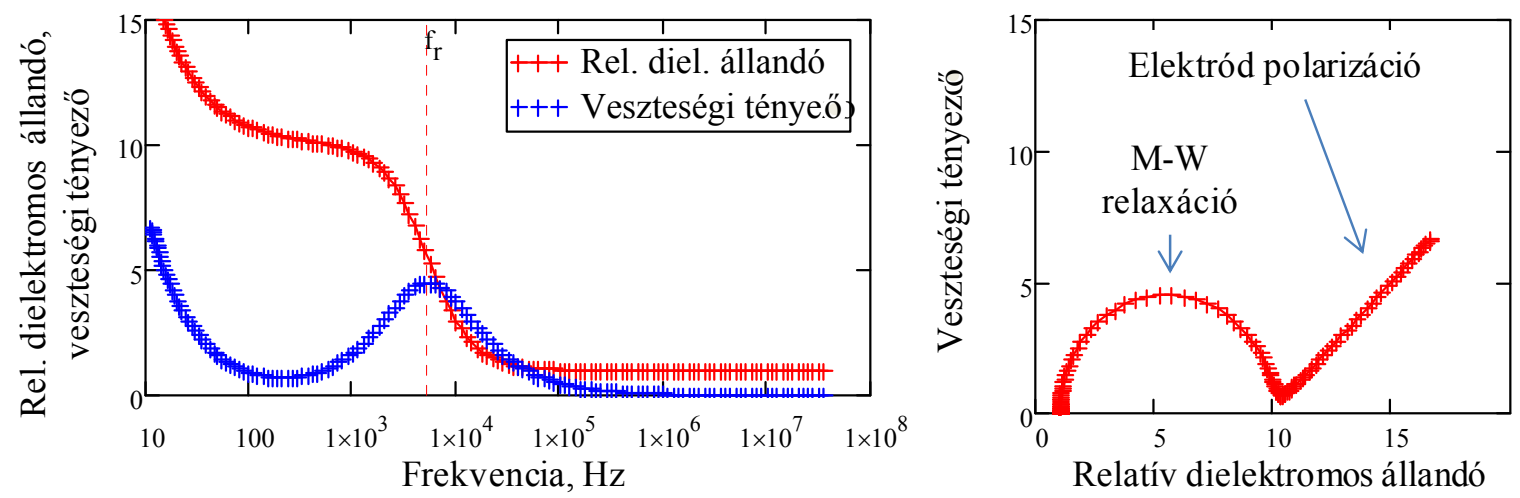

9. ábra Az elektród polarizáció szemléltetése a Maxwell-Wagner relaxációval együtt a frekvencia függvényében és Argand diagramon (forrás: Gillay)

A 9. ábrán jól látható a relatív dielektromos állandó és veszteségi tényező gyors emelkedése a nulla frekvenciát közelítve. Az Argand ábrán megjelent az elektród polarizációt jelző egyenes szakasz.

Az elektród polarizációval szemben az ionos vezetés hatása különbözö, ami a 10. ábrán látható. A szimuláció hasonlóan történt, mint az előzőkben. A permittivitás Debye-féle frekvencia függése egy $10^{-8} \mathrm{Sm} / \mathrm{m}$ vezetőképességből adódó veszteségi tényezővel lett növelve.
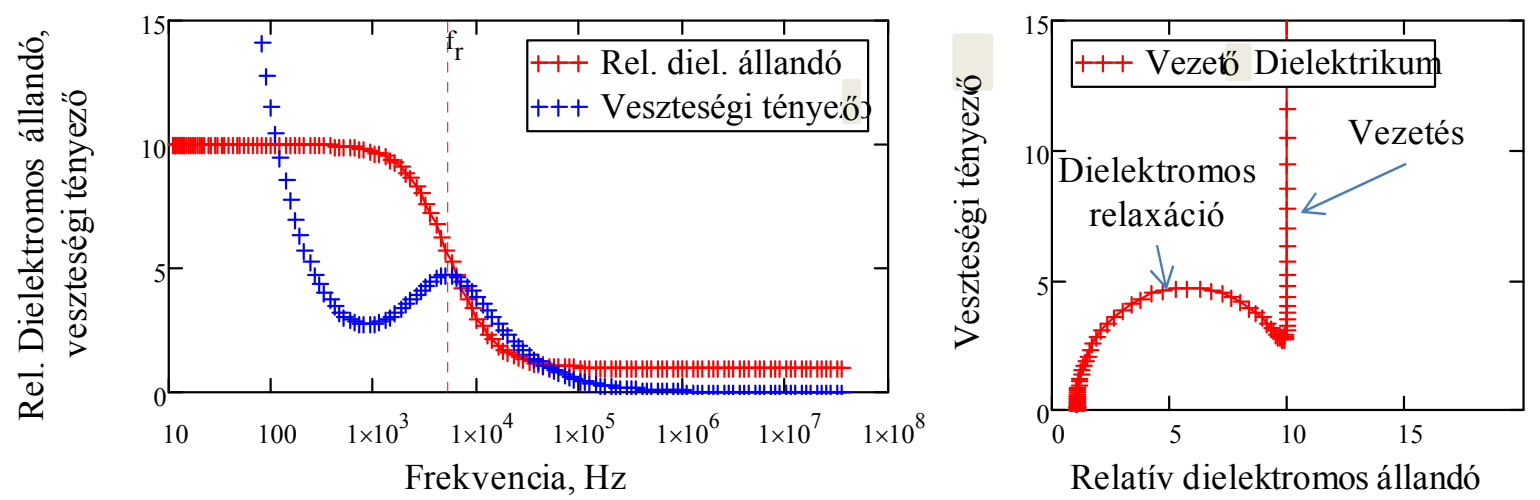

10. ábra Vezető dielektrikum permittivitásának szemléltetése a frekvencia függvényében és Argand diagramon (forrás: Gillay)

Jól látható, hogy az ionos vezetés nem hat a relatív dielektromos állandóra, csak a veszteségi tényező értékét növeli, és az Argand ábrája egy függőleges egyenest tartalmaz, és nem egy $90^{\circ}$-nál kisebb szöget bezáró egyenest, mint az elektród polarizáció esetében (von Hippel 1995b).

Mivel a dielektromos relaxációkat is egy sorosan kapcsolt kapacitás és ellenállásként lehet modellezni Funk a 11. ábrán látható áramköri modellt javasolta a gabona modellezésére, amely megjeleníti a fó relaxációs jelenségeket a kis frekvenciáktól a nagyobb felé haladva: elektród polarizáció, Maxwell-Wagner relaxáció és a vízmolekulák dielektromos relaxációja. 


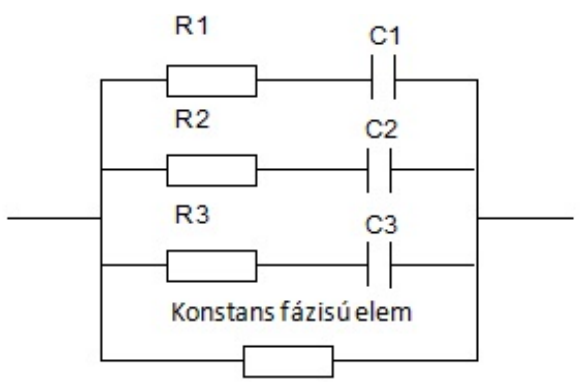

11. ábra A tesztcellában lévő gabona egyszerüsített helyettesítő áramköre. R1 és $\mathrm{C} 1$ reprezentálja a szabad víz, R2 ésC2 a kötött víz relaxációját. R3 és C3 reprezentálja a Maxwell-Wagner relaxációt és a konstans fázisú elem az elektród polarizációt jelképezi.

Egy passzív elektromos hálózat nagymértékben egyszerüsíthető kivéve az állandó fázisú elemet, melyet nem lehet megjeleníteni fizikailag megvalósítható kapacitások és ellenállások kombinációjával (Hasted 1973a, Funk 2001).

\subsection{AZ IRODALOM ÖSSZEFOGLALÁSA}

Az irodalom kutatása során bizonyossá vált, hogy az LLL keverék egyenlet és sürüségkorrekció írja le leghatékonyabban a gabonák viselkedését. A gyakorlati életben több olyan körülmény is előfordul, ami kérdésessé teheti az LLL sürüségkorrekció hatékonyságát. Ilyen az online alkalmazásokban a gabonaoszlop által okozott nyomás, vagy egy berendezés vibrációja.

Továbbá felmerült a kérdés, hogy a különböző mintatartó kialakításoknál, például hengerkondenzátornál vagy síkkondenzátornál azonos módon müködik-e az LLL sürüségkorrekció. Ez azért lehet kérdés, mert míg a síkkondenzátorban közel homogén az elektromos tér, addig a hengerkondenzátorban erősen inhomogén.

Az inhomogén nedvességeloszlás által okozott nedvességmérési hibák széles körben ismertek, de kimerítő kutatás még nem született e hatások vizsgálatára $100 \mathrm{MHz}$ alatti frekvenciatartományban.

Az Argand diagramos ábrázolás és áramköri modellek alkalmasak lehetnek a gabona viselkedésének megjelenítésére és megértéséhez. 


\section{CÉLKITÜZÉSEK}

Munkám két fö témakörre összpontosult. Az első témaköröm a betöltési módok és a nyomás hatásának vizsgálata volt. A másodikban az inhomogén nedvességeloszlás dielektromos jellemzőkre gyakorolt hatását vizsgáltam meg. Doktori munkám célja az alábbi kérdések megválaszolása volt:

\section{A BETÖLTÉSI MÓDOK ÉS A NYOMÁS HATÁSÁNAK VIZSGÁLATA}

1. A betöltési módok és a nyomás hatással vannak-e:
a. a gabonák dielektromos jellemzőire,
b. az LLL sürüségkorrekció hatékonyságára,
c. a gabonák nedvességtartalmának meghatározására?

2. A mérőcella kialakítása befolyásolja-e az LLL sürüségkorrekció hatékonyságát?

3. Az egyes betöltési módok és a nyomás eltérően hatnak-e a gabona dielektromos jellemzőire?

\section{AZ INHOMOGÉN NEDVESSÉGELOSZLÁS HATÁSA}

\section{A szemeken belüli egyenlőtlen nedvességeloszlás vizsgálata}

4. A szemeken belüli inhomogén nedvességeloszlás okoz-e szignifikáns különbséget a kukorica dielektromos jellemzőiben és ebből következően a számított nedvességtartalom értékekben? A jelenségre van-e befolyása a mérőfrekvencia megválasztásának?

5. Mekkora a számított nedvességtartalom különbség a kiegyenlítődött és az inhomogén nedvességeloszlású minta között különböző nedvességtartalomnál és mérőfrekvencián?

6. Lehetséges-e dielektromos módszerrel megkülönböztetni a kiegyenlítődött és az inhomogén nedvességeloszlású szemeket tartalmazó gabonamintákat?

\section{Száraz-nedves gabonakeverékek vizsgálata}

7. A szemek közötti egyenlötlen nedvességeloszlás okoz-e szignifikáns különbséget a dielektromos jellemzőkben és ebből következően a számított nedvességtartalom értékekben? A jelenségre van-e befolyása a mérőfrekvencia megválasztásának?

8. Mekkora a száraz-nedves kukoricakeverékek kiegyenlítődés előtti és utáni számított nedvességtartalom különbsége különbözö nedvességtartalmon és keverési arányok mellett?

9. Lehetséges-e dielektromos módszerrel megkülönböztetni a száraz-nedves gabonaszemek keverékéből álló mintát a már kiegyenlítődött, egyenletes nedvességeloszlású mintától? 


\section{ANYAGOK ÉS MÓDSZEREK}

\subsection{ANYAGOK}

Vizsgálataimhoz kukoricát és szóját használtam. A kukoricaszemek mérete, alakja és nedvességtartalmának széles határok közötti előfordulása megnehezíti a dielektromos méréseket. A szójára a közel gömb alakja és a dielektromos tulajdonságai miatt esett választásom.

A Fizika-Automatika Tanszéken végzett méréseimhez kézi és gépi betakarítású Pioneer hibrid kukoricát használtam. A nagy nedvességtartalmú kukoricacsöveket kézzel morzsoltam. A romlási folyamatok elkerülése miatt a mintákat felhasználásig $4-6{ }^{\circ} \mathrm{C}$ hőmérsékleten tároltam. A mintákat a kísérletek előtt légmentesen lezárt, müanyag zacskóban kiterítve hagytam szobahőmérsékletre $\left(20-22^{\circ} \mathrm{C}\right)$ felmelegedni. Minden mérés előtt megmértem a minta hőmérsékletét, a hőmérséklet korrekció elvégzése céljából. A minták nedvességtartalmát a magyar szabvány (MSZ6367/3-83) által elöírt szárítószekrényes mérésekkel határoztam meg. A száraznedves keverékek kísérleteihez használt visszanedvesített kukorica mintákat a 13,1%-os száraz kukorica és a kívánt 18,20, 25, 30\%-os nedvességtartalom eléréséhez szükséges analitikai pontossággal beállított desztillált víz hozzáadásával készítettem. A mintákat légmentesen zárható, müanyag tartókban tároltam $4-6{ }^{\circ} \mathrm{C}$ hömérsékleten 1 hétig, naponta 3-szor átmozgatva. A visszanedvesített minták nedvességtartalmát Burrows 700 nedvességmérővel ellenőriztem, felhasználás előtt.

Az USDA-GIPSA-nál végzett kísérleteket 11,2-35,2 \% közötti nedvességtartalmú kukoricákkal és 9-18 \% közötti nedvességü szóján végeztem. A minták az USDA-GIPSA 2010. évi felméréséből, az Amerikai Egyesült Államok (továbbiakban USA) teljes területéről származtak. A gabonák nedvességtartalma az amerikai gyakorlatnak megfelelő szárítószekrényes mérésekkel lett meghatározva (Wilhelm et al. 2004).

A relatív dielektromos állandóból a nedvesség kalibrációs összefüggés segítségével számítottam ki a nedvességtartalmat (a továbbiakban számított nedvességtartalom). A nedvesség kalibráció az USDA GIPSA 1999. évi felméréséből származó 236 kukorica minta felhasználásával készült. A kukoricaminták nedvességtartalma 10-35 \% közötti volt.

\subsection{ALKALMAZOTT TESZTCELLÁK}

A vizsgálataim során három tesztcellát, két síkkondenzátor típusú mérőcellát és egy hengerkondenzátort két eltérő kialakítással (középső elektród toldással vagy nélkül) alkalmaztam. Ezek a tesztcella kialakítások széles körben elterjedtek a dielektromos gabona nedvességmérők piacán. 
Egy adott tesztcellán, a benne lévő gabonával, közvetlenül csak az impedanciát tudjuk mérni, viszont ez nem független a méröcella geometriájától, így nem lehet általános következtetéseket levonni. Szükséges egy olyan paraméter, amely csak a gabonára jellemző a cellától függetlenül. Természetesen adódott a permittivitás használata, amely a legújabb kutatások szerint is a legjobb alap a nedvesség meghatározásához, főleg azért mert ezen alkalmazható a Landau-Lifshitz, Looyenga sürüségkorrekció. Ennek érdekében meg kellett határozni a tesztcellák fizikai modelljét, amellyel a mért gabonaminta permittivitása számolható.

\subsubsection{GAC tesztcella}

A Fizika-Automatika Tanszéken történt mérésekhez egy módosított DICKEY-john GAC 2100 tesztcellát használtam (Funk et al. 1978). A tesztcellára a továbbiakban GAC tesztcellaként hivatkozom. A tesztcella és az LRC precíziós mérők közötti kapcsolat koaxiális kábeleken keresztül történik BNC csatlakozókkal amelyek a tesztcella külső és belső elektródok kivezetéseihez voltak forrasztva (12. ábra).
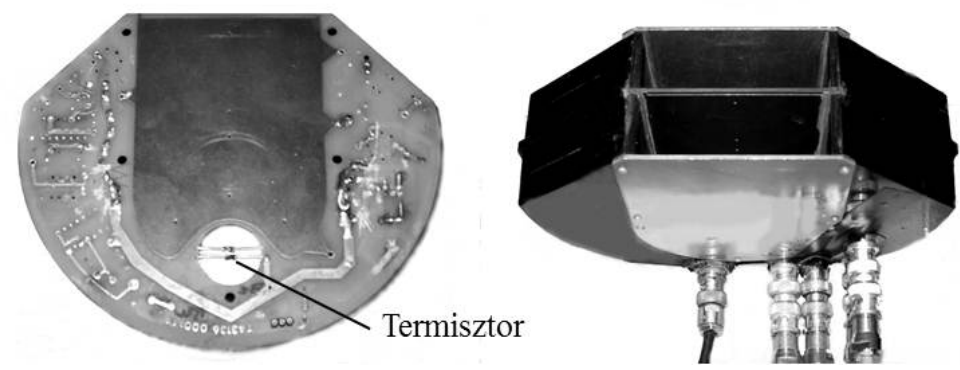

12. ábra GAC tesztcella központi elektródja és az összeszerelt tesztcella

A középső elektród aranyozott vörösrézlemez, a két külső elektród eloxált alumínium. Az elektródák közötti távolság 25,4 mm, az "aktív" elektróda területe $0,013 \mathrm{~m}^{2}$. A tesztcella fizikai modellje (13. ábra) segítségével a mért párhuzamos kapacitás $\left(\mathrm{C}_{\mathrm{m}}\right)$ és a vezetőképesség $\left(\mathrm{G}_{\mathrm{m}}\right)$ értékeiből a komplex permittivitás $\left(\varepsilon^{*}\right)$, a relatív dielektromos állandó $\left(\varepsilon_{\mathrm{r}}^{\prime}\right)$ és a veszteségi tényező $\left(\varepsilon_{\mathrm{r}}^{\prime \prime}\right)$ kiszámolható, melyek ismeretében és a nedvesség kalibrációs összefüggés használatával meghatározható a gabonaminta nedvességtartalma. 


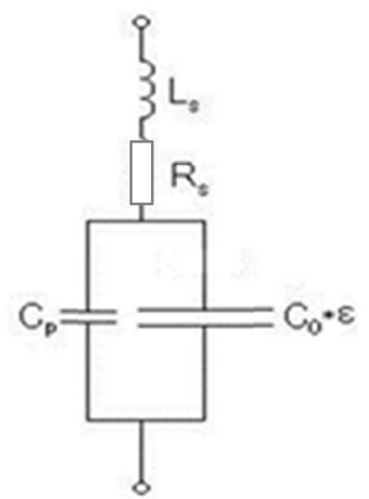

13. ábra A síkkondenzátor tesztcella helyettesítő áramköre

A tesztcella komplex impedanciája $\left(Z^{*}\right)$ a mért párhuzamos kapacitás $\left(\mathrm{C}_{\mathrm{m}}\right)$ és a vezetőképesség $\left(\mathrm{G}_{\mathrm{m}}\right)$ segítségével (23):

$$
Z^{*}=\left(G_{m}+j \cdot \omega \cdot C_{m}\right)^{-1}
$$

ahol $Z^{*}$ a komplex impedancia, $G_{m}$ a mért vezetőképesség és $C_{m}$ a mért kapacitás. A komplex impedanciát felírva a 13. ábrán látható modell paramétereinek segítségével:

$$
Z^{*}=\left[j \cdot \omega \cdot\left(C_{p}+C_{0} \cdot \varepsilon^{*}\right)\right]^{-1}+R_{s}+j \cdot \omega \cdot L_{s}
$$

ahol $L_{s}$ a vezetékek soros induktivitása, $R_{s}$ a vezetékek soros ellenállása, $C_{p}$ a párhuzamos szórt kapacitás, $C_{0}$ az üres tesztcella kapacitása, melyet a geometriai adatokból határoztam meg (4.5 pF), $\varepsilon^{*}$ a komplex permittivitás, $j$, képzetes egység és $\omega$ a körfrekvencia. A (24) egyenletből kifejezve a komplex permittivitást $\left(\varepsilon^{*}\right)(25)$, majd ebből meghatározható a relatív dielektromos állandó $\left(\varepsilon_{\mathrm{r}}{ }^{\prime}\right)$ (26):

$$
\begin{gathered}
\varepsilon^{*}=\varepsilon_{0} \cdot\left(\varepsilon_{r}^{\prime}-j \cdot \varepsilon_{r}^{\prime \prime}\right)=\frac{-\omega \cdot C_{p} \cdot\left(Z *-R_{s}-j \cdot \omega \cdot L_{s}\right)-j}{\omega \cdot C_{0} \cdot\left(Z *-R_{s}-j \cdot \omega \cdot L_{s}\right)} \\
\varepsilon_{r}^{\prime}=\operatorname{Re}\left[\frac{-\omega \cdot C_{p} \cdot\left(Z^{*}-R_{s}-j \cdot \omega \cdot L_{s}\right)-j}{\varepsilon_{0} \cdot \omega \cdot C_{0} \cdot\left(Z^{*}-R_{s}-j \cdot \omega \cdot L_{s}\right.}\right]
\end{gathered}
$$

A modell paramétereinek meghatározását Funk (2002) végezte. A tesztcellák desztillált vízzel való feltöltése után a modell paramétereinek beállítása úgy történt, hogy a desztillált víz mért és az irodalomban publikált permittivitása között optimális legyen az egyezés. A desztillált víz $\left(\varepsilon_{r}{ }^{\prime}=78,5,20{ }^{\circ} \mathrm{C}\right.$-on $)$ és a levegő $\left(\varepsilon_{\mathrm{r}}{ }^{\prime}=1,00\right)$ irodalmi adatainak megfelelően a meghatározott 
modell paraméterek: $C_{p}=5,9 \mathrm{pF}, R_{s}=2,5 \Omega, L_{s}=27,5 \mathrm{nH}$. Ezen összefüggések alkalmazásával a mért adatokat a tesztcella típusától független permittivitássá konvertálható.

\subsubsection{UGMA tesztcella}

Az USDA-GIPSA-nál lehetőségem nyílt arra, hogy a 2012-ben az Amerikai Egyesült Államokban bevezetett, hivatalos nedvességmérési technológia alapjául szolgáló ún. mester tesztcellák közül az egyiket a használhassam. A mérési technológia neve után Unified Grain Moisture Algorithm (egyesített gabona nedvességmérő módszer), rövidítve UGMA, a továbbiakban az UGMA tesztcella megnevezést használom (14. ábra).
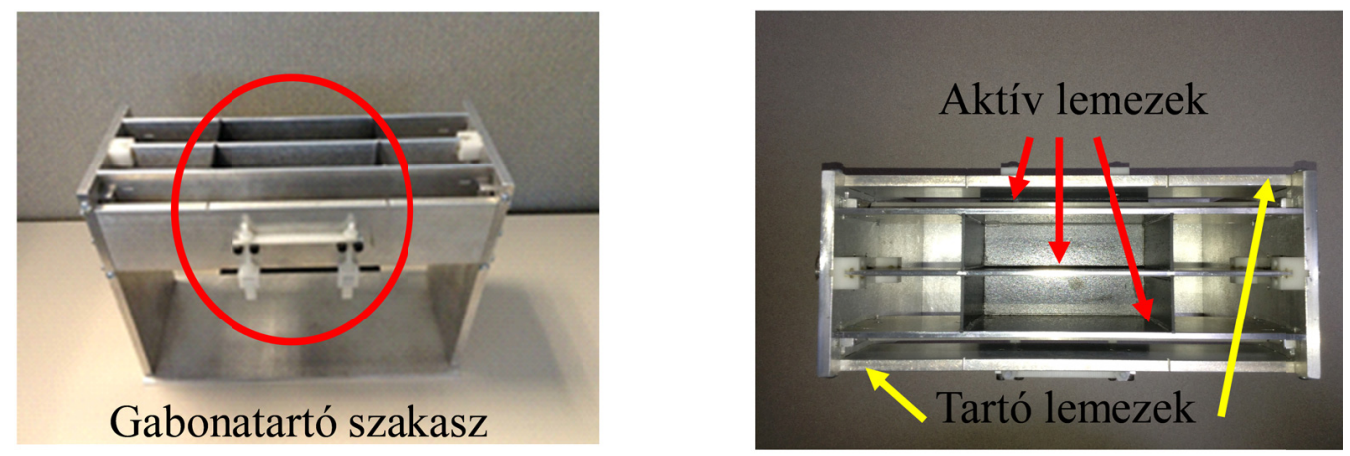

14. ábra A UGMA tesztcella oldal- és felülnézetben

Az UGMA tesztcella 3,2 mm vastag, párhuzamos alumínium lemezekből épül fel. A tesztcella aktív része a középső elektród lemezből és a mellette párhuzamosan elhelyezkedő két másik lemezből áll. Az ezekkel párhuzamos külső, vastagabb lemezek csak a mechanikai stabilitást

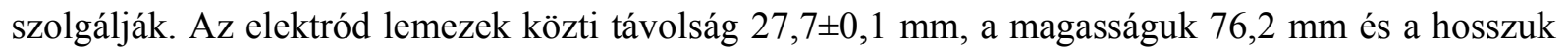
$245 \mathrm{~mm}$ volt. A gabona a tesztcella középső 101,7 mm hosszú részében helyezhető el, és egy nyitható mủanyag ajtó tartja a gabonát alulról a cellában. A tesztcella térfogata 430,16 ml. A tesztcella két végén N-típusú csatlakozók találhatók, amelyeknek középső része a tesztcella középső lemezéhez, a külső részük a két szélső aktív lemezhez csatlakozik. (Funk et al. 2010)

A méréseim $100 \mathrm{MHz}$ alatti frekvenciatartományban történtek, ezért a tesztcellát úgynevezett nyitott módban használtam, azaz a tesztcella végén nem volt záró impedancia elem. Arelatív dielektromos állandót a (27) képlettel lehet meghatározni:

$$
\varepsilon^{\prime}{ }_{r}=\frac{C_{m}-C_{s}}{C_{0}}
$$

ahol $\mathrm{C}_{\mathrm{m}}$ a gabonamintát tartalmazó kondenzátor mért kapacitása, $\mathrm{C}_{\mathrm{s}}$ a szórt kapacitás, amely jelen van minden nem ideális kondenzátor esetében, és $\mathrm{C}_{0}$ a gabonatartó szakasz számolt kapacitása. A (27) képlet tényezői részletezve: 


$$
C_{m}=\frac{Y \prime \prime m}{2 \cdot \pi \cdot f}
$$

ahol $\mathrm{Y}_{\mathrm{m}}^{\prime \prime}$ a mért komplex impedancia reciprokának a képzetes része és f a mérési frekvencia.

$$
C_{0}=\varepsilon_{0} \cdot \frac{A \cdot 2}{d} \cdot 1,04
$$

a tesztcella gabonatartó részének a számolt kapacitása, ahol $\varepsilon_{0}$ a vákuum permittivitása, amely $8,854 \cdot 10^{-12} \mathrm{~F} / \mathrm{m}, A$ tesztcella gabonatartó részének a felülete, $\mathrm{d}$ a lemezek távolsága és 1,04 a korrekciós tényező, amely kalibrációval lett meghatározva. A tesztcella számítással meghatározott elméleti kapacitása $\mathrm{C}_{0}=5,139 \mathrm{pF}$. Továbbá

$$
\begin{aligned}
& C_{s}=C_{m 0}-C_{0} \\
& C_{m 0}=\frac{Y \prime^{\prime \prime} m 0}{2 \cdot \pi \cdot f}
\end{aligned}
$$

ahol $\mathrm{C}_{\mathrm{m} 0}$ az üres tesztcella mért kapacitása, ahol $\mathrm{Y}^{\prime \prime}{ }_{\mathrm{m} 0}$ az üres tesztcella mért komplex impedancia reciprokának képzetes része.

A veszteségi tényező számolása a (32) képletettel történik.

$$
\varepsilon^{\prime \prime}{ }_{r}=\frac{Y^{\prime} m}{2 \cdot \pi \cdot f \cdot C_{0}}
$$

ahol $\mathrm{Y}_{\mathrm{m}}^{\prime}$ a mért komplex impedancia reciprokának a valós része. (Funk et al. 2010)

\subsubsection{Hengerkondenzátor}

Méréseimhez egy hengerkondenzátort használtam, amelynek központi elektródja az eredmények ismeretében meg lett hosszabbítva egy szigetelő toldattal. E szigetelő toldat a tesztcella elektromos szempontból inaktív részében található, hatása elhanyagolható, a tesztcella áramköri modelljét nem változtatja meg. A továbbiakban a toldattal rendelkező hengerkondenzátorra, mint módosított hengerkondenzátor hivatkozom. A hengerkondenzátor tesztcella külső elektródjának átmérője 91,4 mm, magassága 191,5 mm. A belső, központi elektródjának átmérője 42,5 mm, magassága 119,5 mm. Mindkét elektród felszíne festékkel bevont. A 15. ábrán a hengerkondenzátor, a módosított hengerkondenzátor és az áramköri modellje látható. 

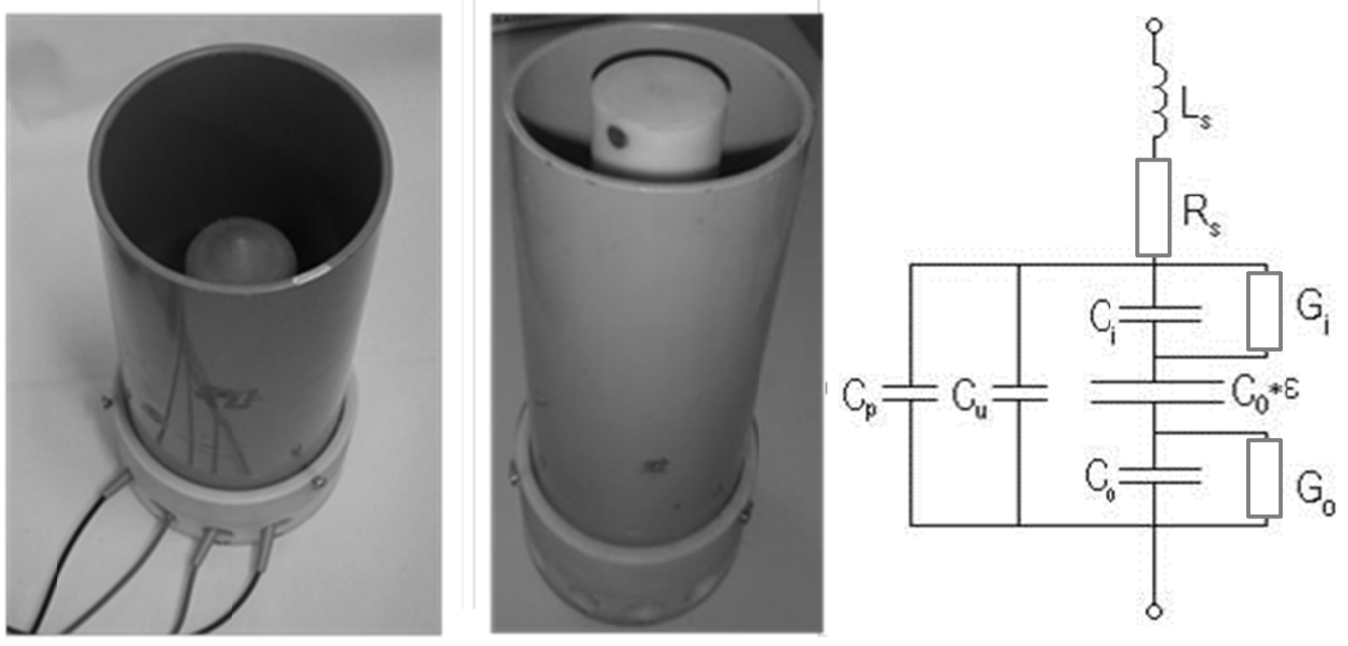

15. ábra A hengerkondenzátor, a módosított hengerkondenzátor tesztcella és áramköri modellje

A tesztcellák komplex impedanciája, Z* a (33) egyenlettel írható fel:

$$
Z^{*}=\left[\left[\left(\frac{1}{\mathrm{G}_{\mathrm{be}}+\mathrm{j} \cdot \omega \cdot \mathrm{C}_{\mathrm{be}}}+\frac{1}{\mathrm{G}_{\mathrm{ke}}+\mathrm{j} \cdot \omega \cdot \mathrm{C}_{\mathrm{ke}}}+\left(\mathrm{j} \cdot \omega \cdot \mathrm{C}_{0} \cdot \varepsilon^{*}\right)^{-1}\right)\right]^{-1}+\mathrm{j} \cdot \omega \cdot\left(\varepsilon^{*} \cdot \mathrm{C}_{\mathrm{in}}+\mathrm{C}_{\mathrm{p}}\right)\right]^{-1}+\mathrm{R}_{\mathrm{s}}+\mathrm{j} \cdot \omega \cdot \mathrm{L}_{\mathrm{s}}
$$

ahol $L_{s}$ a vezetékek soros induktivitása, $R_{s}$ a vezetékek soros ellenállása, $C_{p}$ a párhuzamos szórt kapacitás, $C_{\text {in }}$ a belső elektród feletti inaktív rész kapacitása, $C_{b e}$ belső elektród kapacitása, $G_{b e} a$ belső elektród vezetőképessége, $\mathrm{C}_{\mathrm{ke}}$ a külső elektród kapacitása, $\mathrm{G}_{\mathrm{ke}}$ a külső elektród vezetöképessége, $\mathrm{C}_{0}$ : az üres tesztcella kapacitása, $\varepsilon^{*}$ a komplex permittivitás, $\omega$ a körfrekvencia.

A GAC tesztcellánál ismertetett módon határozhatók meg a modell paraméterei: $C_{p}=2,8 \mathrm{pF}$, $R_{S}=2,2 \Omega, L_{s}=43 \mathrm{nH}$.

\subsection{AZ IMPEDANCIA MÉRÉSE}

A Fizika-Automatika Tanszéken a dielektromos méréseket 100 Hz-től 28,1 MHz-ig terjedő frekvenciatartományban végeztem. A gabonaminták dielektromos spektrumát $100 \mathrm{~Hz}$ és $800 \mathrm{kHz}$ között egy HP-4284A és a 79,4 kHz és 28,1 MHz között egy HP-4285A precíziós LRC mérővel vettem fel (16. ábra). 


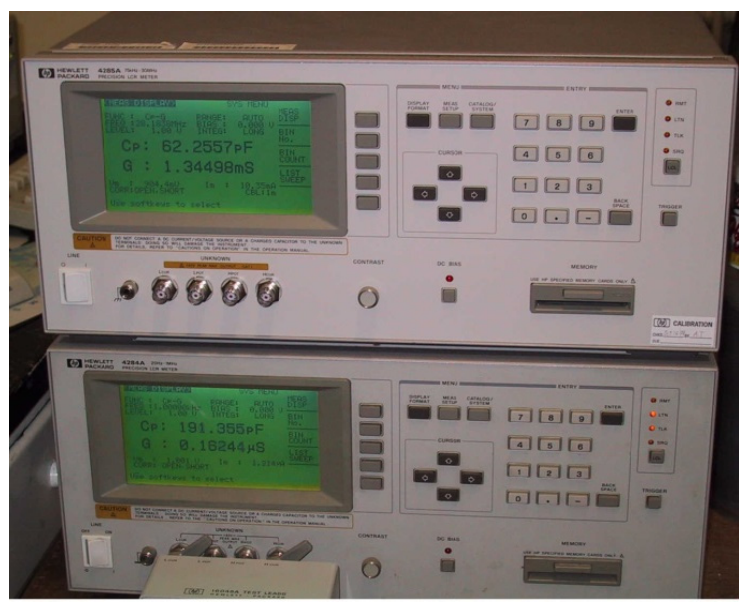

16. ábra HP-4284A és HP-4285A precíziós LRC mérők

A két készülék által mért frekvenciatartományok 79,4 kHz-800 kHz között átlapolódnak. Mindkét berendezés az automatikus kiegyenlítő híd technológiával méri az impedanciát. (HewlettPackard, 1996). A tesztcella négy koaxiális kábellel kapcsolódott a HP-4284A precíziós LRC impedancia mérőhöz. Az impedancia méröt GPIB-n (General Purpose Interface Bus) keresztül vezéreltük számítógép segítségével. A párhuzamos kapacitást és vezetőképességet a $31 \mathrm{~Hz}-800$ kHz frekvenciatartományban mértük 45 ponton, logaritmikus felosztásban. A HP-4285A precíziós impedancia mérővel a 79,4 kHz - 28,1 MHz frekvenciatartományban mértünk.

Az Amerikai Egyesült Államokban a 17. ábrán látható Agilent 4294A impedancia mérő segítségével határoztuk meg a gabonaminták dielektromos karakterisztikáját $100 \mathrm{~Hz}$ és $100 \mathrm{MHz}$ frekvencia között.

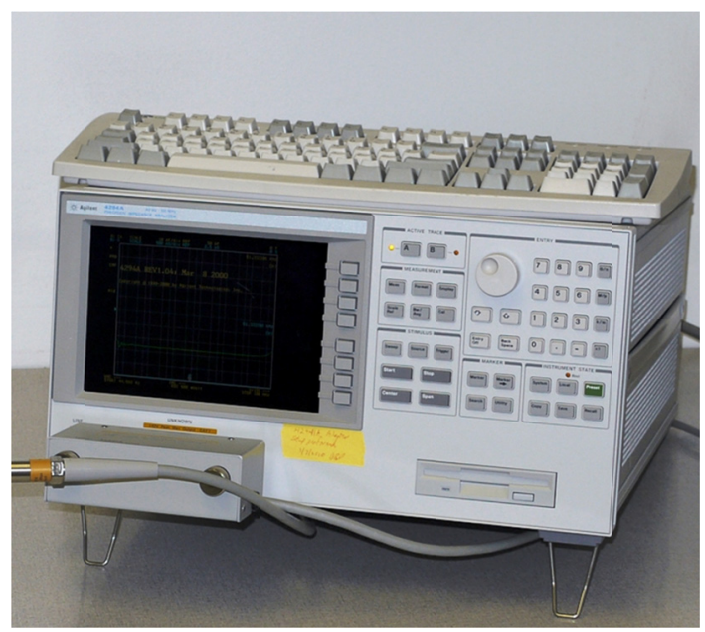

17. ábra Agilent 4294A impedancia mérő 


\subsection{A SZÁMÍTOTT NEDVESSÉGTARTALOM MEGHATÁROZÁSA}

Ahhoz, hogy meghatározzam a méréseim során talált szignifikáns különbségek a dielektromos jellemzők értékeiben mekkora nedvességtartalom változásnak felelnek meg, a relatív dielektromos állandóból ki kellett számítanom a minta becsült nedvességtartalmát (a továbbiakban számított nedvességtartalom). A méréseimhez használt nedvesség kalibrációt David Funk fejlesztette ki. A nedvességtartalom kalibrációs egyenleteit úgy határozta meg, hogy modellezzék a különböző nedvességmérők működését a különböző mérőfrekvenciákon. A mért párhuzamos kapacitás és vezetőképesség értékeket (236 kukorica minta, 2 ismétlés, 10 különböző frekvencia) a (24) és (26) egyenletek alkalmazásával relatív dielektromos állandóvá alakította. Majd alkalmazta az LLL sürüségkorrekciót és a relatív dielektromos állandót konvertálta egy $0,686 \mathrm{~kg} \cdot 1^{-1}$ célsürüségre. A szárítószekrényes nedvességtartalom értékeit ábrázolta a sürüségkorrigált relatív dielektromos állandó függvényében 10 különböző frekvencián. Az így kapott görbékre másodfokú polinomokat illesztett.

A sürüségkorrigált relatív dielektromos állandó $\left(\varepsilon_{\mathrm{r}}^{\prime}\right)$ és a nedvességtartalom $(\mathrm{M})$ kalibrációs összefüggése a (34) másodfokú egyenlet, melynek paramétereit az 1. táblázat tartalmazza.

$$
\mathrm{M}=K 0+K 1 \cdot \varepsilon^{\prime}{ }_{r}+K 2 \cdot\left(\varepsilon^{\prime}{ }_{r}\right)^{2}-K t c \cdot\left(T_{\text {minta }}-25\right)
$$

ahol $K 0, K 1$ és $K 2$ a számított paraméterek, Ktc a hőmérséklet korrekciós paraméter $(0.10 \%$ nedvesség Celsius fokonként) és $T_{\text {minta }}$ a mért minta hőmérséklete.

1. táblázat A kukorica kalibrációs egyenletének együtthatói 10 megadott frekvencián

\begin{tabular}{cccc}
\hline Frekvencia (MHz) & Ko (offset) & K1 (lineáris) & K2 (másodfokú) \\
\hline 0,1 & 8,33 & 1,045 & $-0,01024$ \\
0,2 & 6,3 & 1,498 & $-0,01948$ \\
0,3 & 4,76 & 1,857 & $-0,02836$ \\
0,5 & 2,47 & 2,412 & $-0,04437$ \\
1 & $-1,05$ & 3,316 & $-0,07457$ \\
2 & $-4,7$ & 4,305 & $-0,1106$ \\
3 & $-6,67$ & 4,863 & $-0,13048$ \\
5 & $-8,7$ & 5,453 & $-0,14764$ \\
12 & $-9,98$ & 5,738 & $-0,12261$ \\
18,5 & $-10,08$ & 5,785 & $-0,10727$ \\
\hline
\end{tabular}

A közbenső frekvenciákon interpolációval határozható meg K0, K1 és K2 értékei. 


\subsection{A MÉRÉSI ÖSSZEÁLLÍTÁSOK ÉS A MÉRÉSEK MENETE}

Az impedancia mérések előtt megmértem a minták hőmérsékletét és a mérések után a tesztcellában lévő minta tömegét a szükséges hőmérséklet és sürüségkorrekció alkalmazásához.

\subsubsection{A betöltési módok vizsgálata}

A mérések célja a kukorica minták halmaztömörödöttségének megváltoztatása volt, amit két különböző betöltési móddal, a lassú és gyors betöltésekkel és a tesztcellában lévő gabona felső rétegén alkalmazott különböző nagyságú nyomással értem el.

A különböző betöltések minden tesztcellánál azonos módon történtek. A „lassú” betöltés módszere a következő: A gabonamintákat először lassan, mintegy 30 másodperc alatt töltöttem be tesztcellába, annak folyamatos rázása mellett. A tesztcellát minden esetben túltöltöttem, és a tetején található felesleges gabonát az USDA által előírt módon, szigetelő anyagból készült vonalzóval, a tesztcella tetejére merőlegesen tartva és tökéletesen illeszkedve, "cikk-cakk" mozgással, lehúztam. Így biztosítva, hogy a tesztcellában mindig állandó térfogatú minta kerüljön. Ezután elvégeztem a dielektromos méréseket.

“Gyors" betöltéskor a minta betöltéséhez egy a 18. ábrán látható UGMA tesztcellánál alkalmazotthoz hasonló, a tesztcellák fölé helyezhető betöltő szerkezetet alkalmaztam.

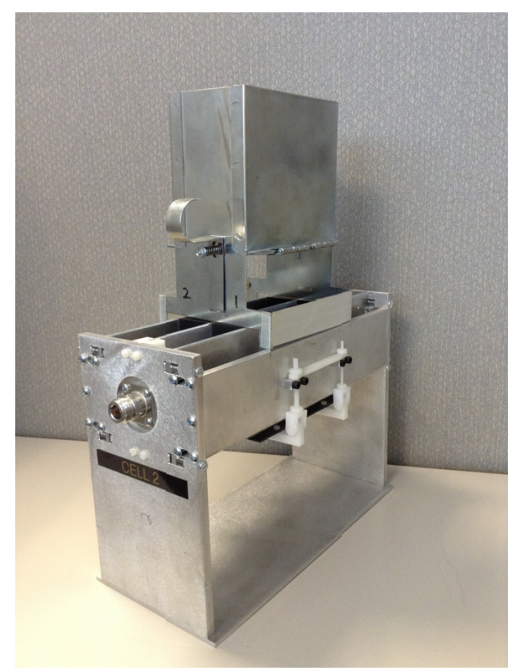

18. ábra Az UGMA tesztcella a gyorsbetöltő szerkezettel

A gabonahalmaz a betöltő szerkezet gombnyomással (UGMA tesztcellánál kar kihúzásával) nyitható ajtaján helyezkedett el, és annak nyitásakor a minta pillanatszerüen másodperc alatt zúdult be tesztcellába, miközben a cella nyugalmi, rázkódásmentes állapotban volt. A tesztcellákat ebben az esetben is túltöltöttem, majd a felesleges gabonát a mintatartó tetejéről lehúztam. Elvégeztem a dielektromos méréseket, majd megmértem a tesztcellában lévő minta tömegét. 


\subsubsection{A nyomás hatásának vizsgálata}

A nyomás által okozott halmaztömörödöttséget kétféle módon értem el. Az egyik esetben a GAC és a hengerkondenzátor, módosított hengerkondenzátor tesztcellákban lévő gabonahalmazt egy SMS TA-XT2 precíziós penetrométerrel, előre beállított erővel nyomtam meg (19. ábra).

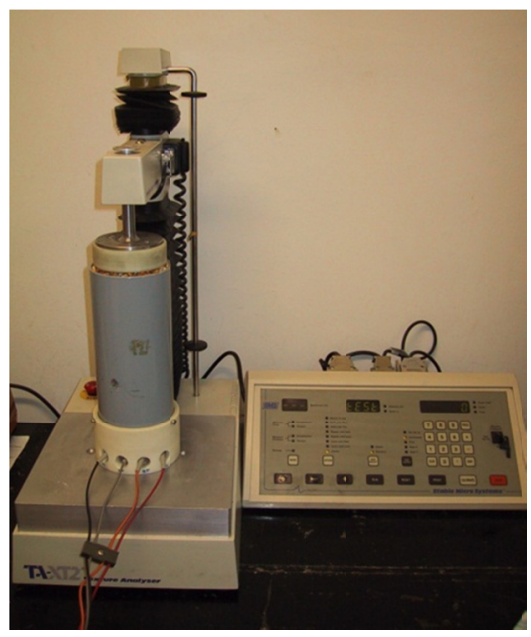

19. ábra A terhelés hatásának vizsgálata SMS TA-XT2 precíziós penetrométerrel a hengerkondenzátor tesztcellával

A dielektromos méréseket a kívánt erő elérésekor mértem, állandó erő mellett, rögzítve az adott erőhöz tartozó maximális deformációt. A deformáció ismeretében számoltam ki a tesztcellában lévő gabonahalmaz sürüségét. A nyomófej szigetelő anyagból készült,relatív dielektromos állandója értéke közel 1.0, így jelenléte nem módosította a mérés eredményét. A kísérletben szereplő kukorica mintákat további mérésre nem használtam.

A másik esetben az UGMA tesztcellával a gabona halmaz tetejére poliuretánból készült, megfelelően kialakított nyomófejet tettem, amire 5 másodpercre 1, 2 és $3 \mathrm{~kg}$ tömegü mérlegsúlyt helyeztem (20. ábra).
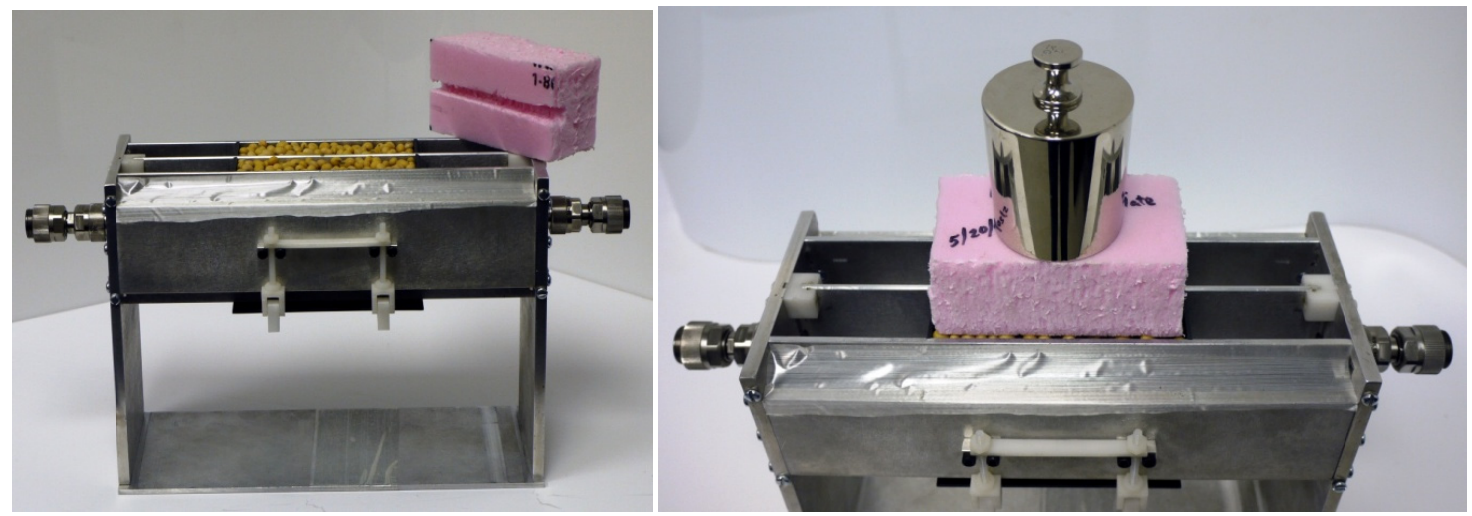

20. ábra Az UGMA tesztcella a poliuretán nyomófejjel 
A dielektromos mérést közvetlenül a mérlegsúly eltávolítása után végeztem el. A kukoricával és szójával végzett méréseket nedvességtartalmanként háromszor végeztem el. Mindkét módszernél a terheléses vizsgálatok elött a mintát minden esetben gyors betöltéssel jutattam a tesztcellákba. A gabonát túltöltöttem, majd a felesleget lehúztam a tesztcella tetejéröl.

A kísérletek során meghatározott nagyságú terhelőerőket (0-100 N között) alkalmaztam, azonban az adott terhelőerő különböző nyomás értéket jelent az egyes tesztcelláknál a különböző nyomófelület miatt. A terhelőerők és nyomás értékké való konverzióját a 2. táblázatban tüntettem fel.

2. táblázat A terhelőerő és a nyomás konverziós táblázata

\begin{tabular}{|c|c|c|c|c|c|c|c|}
\hline \multicolumn{6}{|c|}{ Dielektromos mérés nyomás alatt } & \multicolumn{2}{|c|}{$\begin{array}{c}\text { Dielektromos mérés a nyomás } \\
\text { megszúnte után }\end{array}$} \\
\hline \multicolumn{2}{|c|}{ Hengerkondenzátor } & \multicolumn{2}{|c|}{$\begin{array}{c}\text { Módosított } \\
\text { hengerkondenzátor }\end{array}$} & \multicolumn{2}{|c|}{ GAC tesztcella } & \multicolumn{2}{|c|}{ UGMA tesztcella } \\
\hline Erö $(\mathrm{N})$ & Nyomás (kPa) & Erő $(\mathrm{N})$ & Nyomás (kPa) & Erő $(\mathrm{N})$ & Nyomás (kPa) & Erő $(\mathrm{N})$ & Nyomás (kPa) \\
\hline 0 & 0.0 & 0 & 0.0 & 0 & 0.0 & 0 & 0.0 \\
\hline 5 & - & 5 & - & 5 & 1.4 & 5 & - \\
\hline 10 & 1.5 & 10 & 1.9 & 10 & 2.8 & 10 & 1.8 \\
\hline 15 & - & 15 & - & 15 & 4.2 & 15 & - \\
\hline 20 & 3.0 & 20 & 3.9 & 20 & 5.6 & 20 & 3.5 \\
\hline 25 & - & 25 & - & 25 & 7.0 & 25 & - \\
\hline 50 & 7.6 & 50 & 9.7 & 50 & - & 50 & - \\
\hline 75 & 11.4 & 75 & 14.6 & 75 & - & 75 & - \\
\hline 100 & 15.2 & 100 & 19.4 & 100 & - & 100 & - \\
\hline
\end{tabular}

\subsubsection{Inhomogén nedvességeloszlás}

Egy tesztcellában lévő gabonaminta kétféle módon lehet inhomogén a benne lévő nedvesség eloszlása szempontjából. Az egyenlőtlen nedvességeloszlás jelentkezhet az egyes magokon belül, vagy a minta egészét tekintve, a száraz-nedves gabonaszemek keverékében a gabonaszemek között (21. ábra).
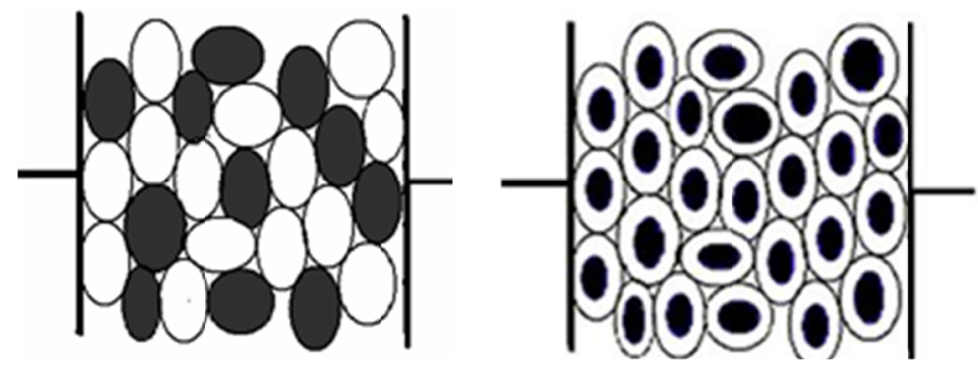

Nedves

Száraz

21. ábra Inhomogén nedvességeloszlás a magok között (bal oldal); és magon belül (jobb oldal)

kapacitív méröcellában 


\subsubsection{A gabonaszemeken belüli egyenlőtlen nedvességeloszlás vizsgálata}

A kukorica mintákat Venticell 110 típusú laboratóriumi szárítószekrényben szárítottam $70{ }^{\circ} \mathrm{C}$ hőmérsékleten. A szárított minták szárítószekrénnyel meghatározott kiindulás nedvességtartalmát és a végső nedvességét az 3. táblázat tartalmazza.

3. táblázat Szárítószekrényes nedvességtartalom értékek szárítás előtt és után

\begin{tabular}{ccc}
\hline $\begin{array}{c}\text { Nedvességtartalom szárítás előtt, } \\
\text { \% }\end{array}$ & $\begin{array}{c}\text { Szárítási idő, } \\
\text { h }\end{array}$ & $\begin{array}{c}\text { Nedvességtartalom szárítás után, } \\
\text { \% }\end{array}$ \\
\hline 22,9 & 1 & 18,5 \\
22,9 & 2 & 16,5 \\
25,4 & 1 & 20,3 \\
25,4 & 2,3 & 15,6 \\
25,4 & 3 & 14,9 \\
$26,2^{*}$ & 2 & 14,6 \\
$26,2^{*}$ & 3 & 12,1 \\
$26,2^{*}$ & 4 & 11,2 \\
$26,2^{*}$ & 5 & 10,2 \\
34,0 & 2 & 23,5 \\
34,0 & 3 & 21,0 \\
\hline
\end{tabular}

* Burrows 700 nedvességmérővel

A kukorica mintákat egy 170 × 170 x 20 mm fémrács tartóba helyeztem, az egyenletes száradást biztosítva $2 \operatorname{szem~}(\approx 1 \mathrm{~cm})$ rétegvastagságban $(22$. ábra).

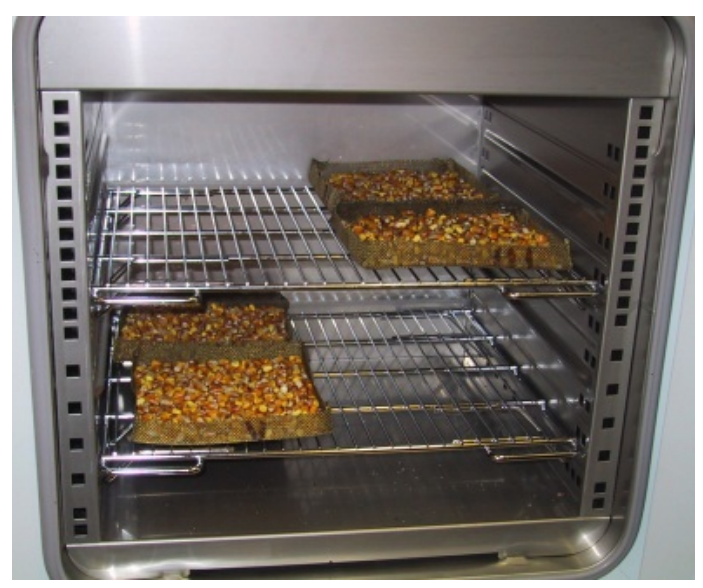

22. ábra Kukorica szárítása a szárító szekrényben fémhálóból készült tálcákon

A száradási idő letelte után kivettem a mintákat a szárítószekrényből, majd légmentesen zárható mủanyag zacskókba tettem, és hagytam szobahőmérsékletre, $20-21^{\circ} \mathrm{C}$-ra lehülni. Minden mintát mindkét LRC mérővel megmértem háromszoros ismétléssel. A dielektromos mérések után a gabonákat egy légmentesen záródó edényben 24 órán keresztül pihentettem, majd megismételtem a 
dielektromos méréseket. Szabványmódszerrel meghatároztam a minták nedvességtartalmát kiegyenlítődés előtt és után.

A doktori munkám során elvégzett kísérletekben alkalmazott tesztcellákat és a mérőműszereket, a felhasznált gabonák faját és a vizsgált nedvességtartalom tartományokat, az adott tartományon belül felhasznált minták számát (ami nem azonos az ismétlés számmal az egyes kísérletekben) a 4. táblázatban foglaltam össze.

4. táblázat Az anyagok és módszerek fejezet összefoglalása

\begin{tabular}{|c|c|c|c|c|c|c|c|c|}
\hline \multirow{3}{*}{\multicolumn{5}{|c|}{$\begin{array}{l}\text { Anyagok és módszerek fejezet témakör szerinti } \\
\text { összesítése }\end{array}$}} & \multicolumn{4}{|c|}{ Tesztcella típusok } \\
\hline & & & & & \multicolumn{2}{|c|}{ Síkkondenzátor } & \multicolumn{2}{|c|}{ Hengerkondenzátor } \\
\hline & & & & & GAC & UGMA & eredeti & módosított \\
\hline \multirow{5}{*}{$\begin{array}{l}\text { I. Betöltési } \\
\text { módok és a } \\
\text { nyomás } \\
\text { hatásának } \\
\text { vizsgálata }\end{array}$} & \multicolumn{4}{|c|}{ Alkalmazott tesztcella } & + & + & + & + \\
\hline & \multirow{4}{*}{\multicolumn{2}{|c|}{ A mért gabona minta }} & \multirow[t]{2}{*}{ kukorica } & $\begin{array}{c}\text { Nedvesség- } \\
\text { tartalom }\end{array}$ & $13,5-26,0 \%$ & $11,2-28,8 \%$ & $16,2-31,8 \%$ & $16,2-31,9 \%$ \\
\hline & & & & Minta szám & 8 & 8 & 6 & 8 \\
\hline & & & \multirow[t]{2}{*}{ Szója } & $\begin{array}{c}\text { Nedvesség- } \\
\text { tartalom }\end{array}$ & & $10,6-20,3 \%$ & & \\
\hline & & & & Minta szám & & 12 & & \\
\hline \multirow{8}{*}{$\begin{array}{l}\text { II. Inhomogén } \\
\text { nedvesség- } \\
\text { eloszlás } \\
\text { hatásának } \\
\text { vizsgálata }\end{array}$} & \multirow{5}{*}{$\begin{array}{c}\text { Szemek } \\
\text { között } \\
\text { (keverékek) }\end{array}$} & \multicolumn{3}{|c|}{ Alkalmazott tesztcella } & + & & & \\
\hline & & \multirow{4}{*}{$\begin{array}{l}\text { A mért } \\
\text { gabona } \\
\text { minta }\end{array}$} & \multirow{2}{*}{$\begin{array}{c}\text { Természetes } \\
\text { kukorica }\end{array}$} & $\begin{array}{c}\text { Nedvesség- } \\
\text { tartalom }\end{array}$ & $13,1-34,0 \%$ & & & \\
\hline & & & & Minta szám & 9 & & & \\
\hline & & & \multirow{2}{*}{$\begin{array}{l}\text { Vissza- } \\
\text { nedvesített } \\
\text { kukorica }\end{array}$} & $\begin{array}{c}\text { Nedvesség- } \\
\text { tartalom }\end{array}$ & $18,0-30,0 \%$ & & & \\
\hline & & & & Minta szám & 16 & & & \\
\hline & \multirow{3}{*}{$\begin{array}{l}\text { Szemeken } \\
\text { belül } \\
\text { (szárítás) }\end{array}$} & \multicolumn{3}{|c|}{ Alkalmazott tesztcella } & + & & & \\
\hline & & \multirow{2}{*}{$\begin{array}{l}\text { A mért } \\
\text { gabona } \\
\text { minta }\end{array}$} & \multirow[t]{2}{*}{ Kukorica } & $\begin{array}{c}\text { Nedvesség- } \\
\text { tartalom }\end{array}$ & $22,9-34,0 \%$ & & & \\
\hline & & & & Minta szám & 11 & & & \\
\hline \multirow{5}{*}{$\begin{array}{l}\text { III. Dielektromos } \\
\text { spektrum } \\
\text { tulajdonságai } \\
100 \mathrm{MHz} \text { alatt }\end{array}$} & \multicolumn{4}{|c|}{ Alkalmazott tesztcella } & & + & & \\
\hline & \multirow{4}{*}{\multicolumn{2}{|c|}{ A mért gabona minta }} & \multirow[t]{2}{*}{ Kukorica } & $\begin{array}{c}\text { Nedvesség- } \\
\text { tartalom }\end{array}$ & & $11,2-35,2 \%$ & & \\
\hline & & & & Minta szám & & 8 & & \\
\hline & & & \multirow[t]{2}{*}{ Szója } & $\begin{array}{l}\text { Nedvesség- } \\
\text { tartalom, \% }\end{array}$ & & $8,8-22,9 \%$ & & \\
\hline & & & & Minta szám & & 12 & & \\
\hline
\end{tabular}

\subsubsection{Keverékek vizsgálata}

A keverékek vizsgálatát 3 oldalról közelítettem meg. Elsőként, ugyanazon száraz kukorica mintából és 3 különböző nedvességtartalmú, nedves kukoricából készítettem 50:50 tömegarányú keverékeket, minden nedvességtartalmon 3 adagot (23. ábra): 


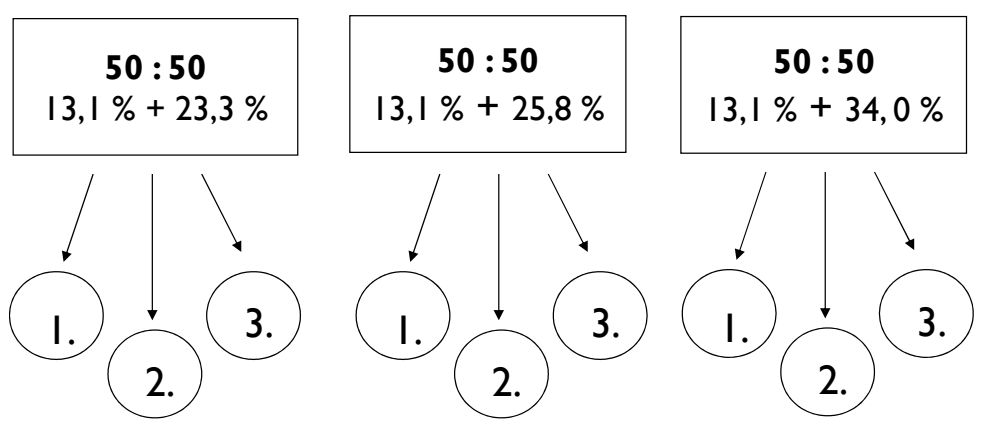

23. ábra Az 50:50 tömegarányú kukorica keverékek keverési sémája

Az így elkészített keverékek relatív dielektromos állandójából a (34) egyenlet alkalmazásával kiszámítottam a minták nedvességtartalmát. Az 50:50 tömegarányú keverék leírását az 5. táblázat tartalmazza.

5. táblázat A száraz és a nedves kukorica minták 50:50 tömegarányú keverékek keverési táblázata a kiindulási és a keverék minták szárítószekrényes nedvességtartalmával

\begin{tabular}{ccc}
\hline $\begin{array}{c}\text { Száraz minta } \\
\text { nedvességtartalma, \% }\end{array}$ & $\begin{array}{c}\text { Nedves minta } \\
\text { nedvességtartalma \% }\end{array}$ & $\begin{array}{c}\mathbf{5 0 : 5 0} \text { arányú keverék minta } \\
\text { nedvességtartalma, \% }\end{array}$ \\
\hline 13,1 & 23,3 & 17,7 \\
13,1 & 23,3 & 17,8 \\
13,1 & 23,3 & 17,5 \\
13,1 & 25,8 & 18,8 \\
13,1 & 25,8 & 19,0 \\
13,1 & 25,8 & 19,0 \\
13,1 & 34,0 & 23,1 \\
13,1 & 34,0 & 22,8 \\
13,1 & 34,0 & 23,2 \\
\hline
\end{tabular}

A második kísérletsorozatban a 13,1 \% nedvességtartalmú mintából visszanedvesítéssel 18-30 \% nedves mintákat készítettem. A keverési arányokat kétféleképpen állítottam be. Első lépésben a 16,5 \% nedvességtartalmú keverékek létrehozatala volt a célom (24. ábra).

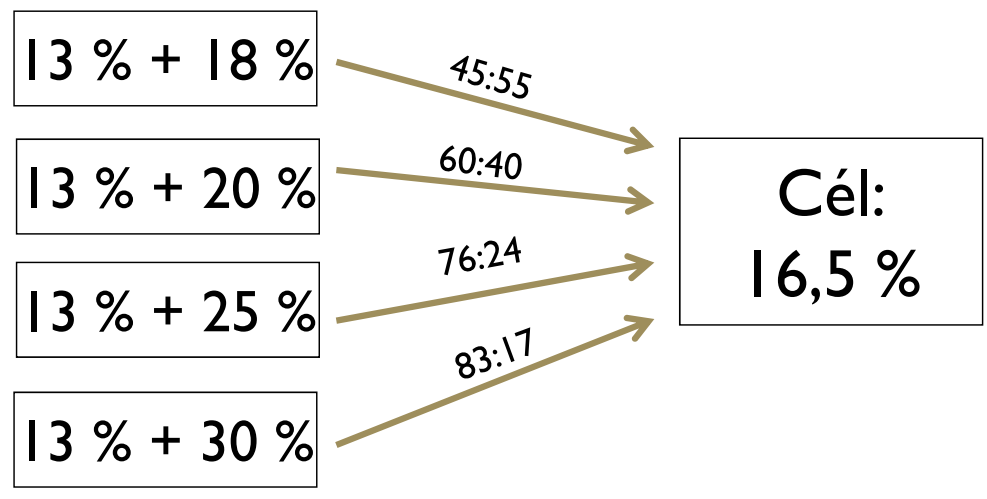

24. ábra Adott nedvességtartalomra beállított keverékek keverési sémája 
Végezetül, különböző tömegarányok hatását vizsgáltam meg négy különböző nedvességtartalmon (25. ábra).

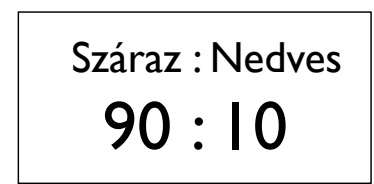

$13 \%+18 \%$

$13 \%+20 \%$

$13 \%+25 \%$

$13 \%+30 \%$

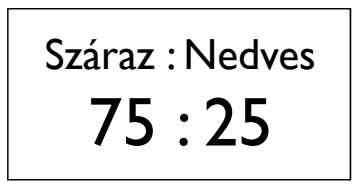

$13 \%+18 \%$

$13 \%+20 \%$

$13 \%+25 \%$

$13 \%+30 \%$

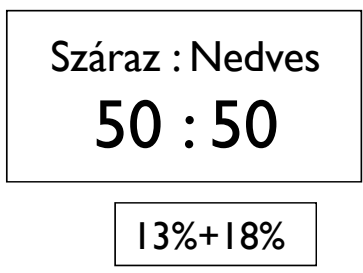

$13 \%+20 \%$

$13 \%+25 \%$

$13 \%+30 \%$

25. ábra Különböző keverési arányú kukorica keverékek sémája

A beállított nedvességtartalom ellenőrzésére a visszanedvesített minták nedvességtartalmát DICKEY-john GAC-2100 gyors nedvességmérővel határoztam meg. A keverékek kiegyenlítődés előtti és utáni nedvességtartalom meghatározása szárítószekrényes módszerrel történt. Az visszanedvesített kukorica mintákból készült keverékek leírását a 6. táblázat tartalmazza.

6. táblázat Visszanedvesített kukorica mintákból készült keverékek keverési táblázata

\begin{tabular}{cccc}
\hline $\begin{array}{c}\text { Száraz minta } \\
\text { nedvességtartalma, \% } \\
\text { (GAC-2100) }\end{array}$ & $\begin{array}{c}\text { Nedves minta } \\
\text { nedvességtartalma, \% } \\
\text { (GAC-2100) }\end{array}$ & $\begin{array}{c}\text { Keverési arány } \\
\text { (száraz:nedves) }\end{array}$ & $\begin{array}{c}\text { 50:50 arányú keverék } \\
\text { minta nedvességtartalma, } \\
\text { \% (Szárítószekrénnyel) }\end{array}$ \\
\hline 13 & 18 & $45: 55$ & 16,4 \\
13 & 20 & $60: 40$ & 16,3 \\
13 & 25 & $76: 24$ & 16,4 \\
13 & 30 & $83: 17$ & 16,6 \\
13 & 18 & $90: 10$ & 14,4 \\
13 & 20 & $90: 10$ & 14,5 \\
13 & 25 & $90: 10$ & 14,8 \\
13 & 30 & $90: 10$ & 15,1 \\
13 & 18 & $75: 25$ & 15,0 \\
13 & 20 & $75: 25$ & 15,4 \\
13 & 25 & $75: 25$ & 16,6 \\
13 & 30 & $75: 25$ & 17,9 \\
13 & 15 & $50: 50$ & 16,2 \\
13 & 20 & $50: 50$ & 16,9 \\
13 & 25 & $50: 50$ & 19,8 \\
13 & 30 & $50: 50$ & 22,8 \\
\hline
\end{tabular}

Mindkét kísérletsorozathoz GAC tesztcellát használtam. A tesztcellát gyors betöltéssel túltöltöttem, majd a gabonafelesleget lehúzással eltávolítottam. A dielektromos mérések menete is azonos volt: közvetlenül az összekeverés után felvettem a minták dielektromos spektrumát mindkét 
LRC mérővel. Minden minta adagot ötszörös ismétléssel mértem, minden ismétlésnél új betöltéssel. Az esetleges nedvességvesztést elkerülendő, a mérések között a mintákat zárható müanyag zacskóban tartottam. A dielektromos mérések után a mintákat légmentesen záródó mủanyag tartókba helyeztem, és 24 órán keresztül pihentettem $20^{\circ} \mathrm{C}$-on. Pihentetés közben a kukoricákat többször átmozgattam a mintatartó kinyitása nélkül. Végezetül ötszörös ismétléssel megmértem a már kiegyenlítődött keverékek dielektromos jellemzőit.

\subsection{AZ ARGAND GÖRBE PARAMÉTEREI}

A következő alfejezetben a mérési eredmények értékeléséhez használt Argand ábrák jellemzőit mutatom be.

A 26. ábrán egy 15,5\% nedvességtartalmú szója relatív dielektromos állandóját és veszteségi tényezőjét ábrázoltam a frekvencia függvényében.

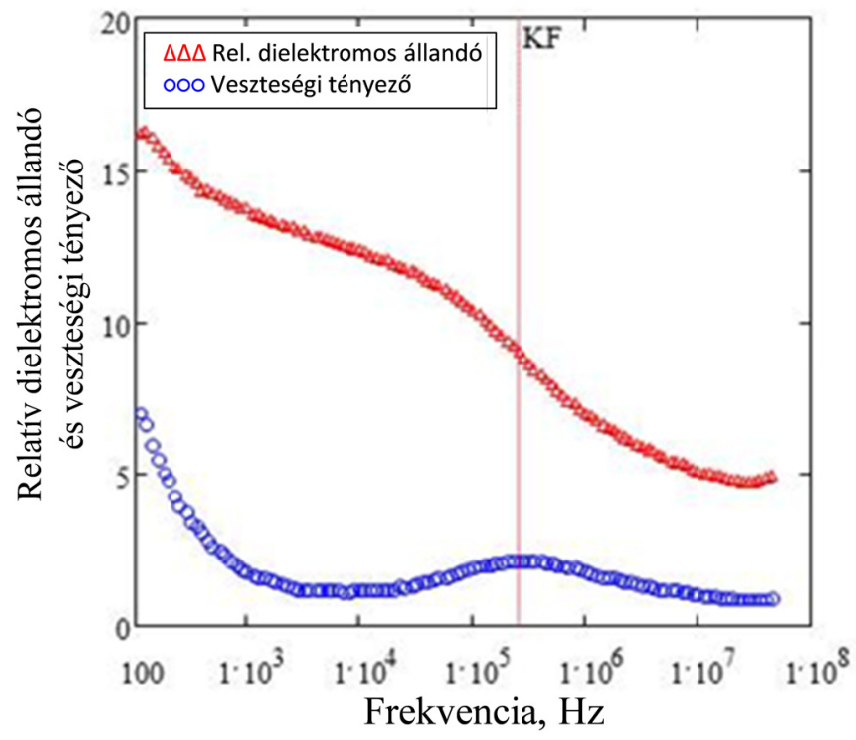

26. ábra relatív dielektromos állandó és veszteségi tényező a frekvencia függvényében $15,5 \%$ nedvességtartalmú szója minta esetén. Karakterisztikus frekvencia: KF $=255 \mathrm{kHz}$-en.

A relatív dielektromos állandó és a veszteségi tényező $1 \mathrm{kHz}$ alatt hirtelen megemelkedik, értéke megnő. A veszteségi tényező lokális maximuma $255 \mathrm{kHz}$-nél található. Ebben a pontban a legnagyobb a relatív dielektromos állandó görbének a meredeksége a Maxwell-Wagner relaxáció tartományában.

Az előbbi adatokat Argand ábrán (a veszteségi tényező a relatív dielektromos állandó függvényében) megjelenítve, meghatározható a görbe egy olyan szakasza, amire egy félkörívet és kis frekvenciákon egy egyenest lehet illeszteni (27. ábra) 


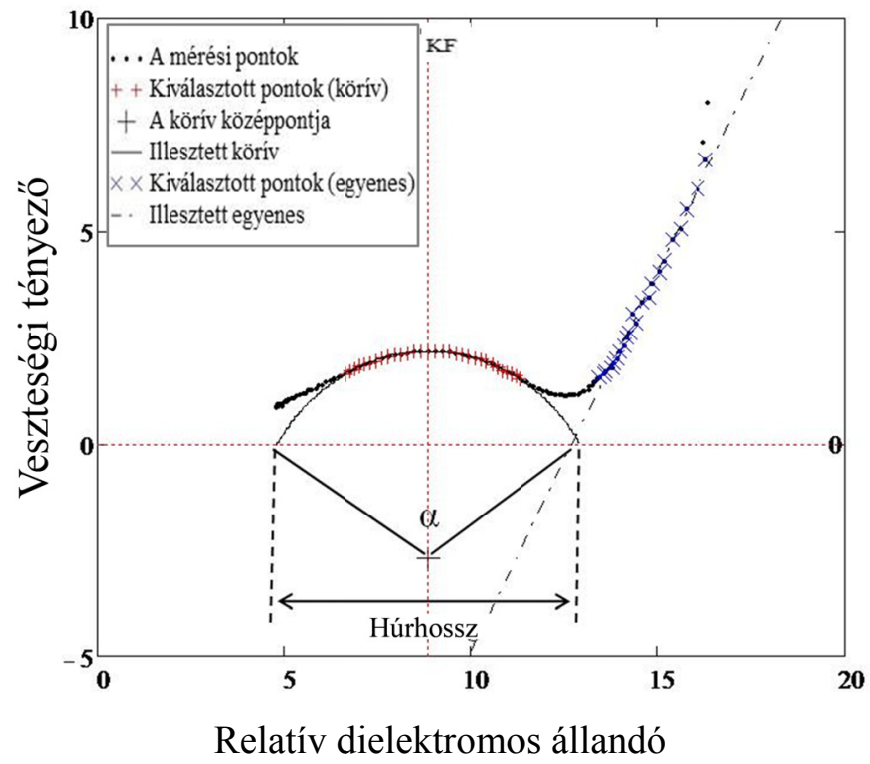

27. ábra Egy 15,5 \% nedvességü szója dielektromos jellemzői Argand ábrán megjelenítve, a mért adatpontokra illesztett körívvel, az illesztett egyenessel és a leíró paraméterekkel (KF:

karakterisztikus frekvencia, $\alpha$ : a körív központi szöge, húrhossz: a relatív dielektromos állandó

különbsége, amely a Maxwell-Wagner relaxáció miatt jött létre).

A mért pontokra illesztett körív a Maxwell-Wagner relaxációt, az illesztett egyenes az elektródpolarizációt mutatja meg a minta dielektromos görbéjén. A görbék illesztéséhez egy félautomata Mathcad programot használtam. A program müködéséhez elsőként meg kellett határozni azt a frekvenciatartományt, amelyben a körívet és az egyenes illesztését végeztem. Az általam mért minták görbéin a legtöbb, de nem minden esetben a két illesztéssel a relaxációs hatásoknak (Maxwell-Wagner, elektród polarizáció) megfelelő frekvenciatartományok jól elhatárolódtak egymástól. A gabonaminták dielektromos viselkedésének leírásához az Argand ábrából az alábbi paramétereket határoztam meg:

Húrhossz: Az illesztett körív és az x-tengely (relatív relatív dielektromos állandó) által meghatározott húr nagysága. E paraméter közvetlenül kapcsolatban áll a Maxwell-Wagner relaxációval. Nagysága a relaxáció erősségét adja meg, azaz hogy mekkora változást okoz a Maxwell-Wagner relaxáció a minta relatív dielektromos állandójának értékében a vizsgált frekvenciatartományban.

Karakterisztikus frekvencia $(\mathrm{KF})$ : A veszteségi tényező lokális maximumához tartozó frekvencia. A Maxwell-Wagner relaxáció rezonancia frekvenciája.

A körív központi szöge $(\alpha)$ : A karakterisztikus frekvenciák eloszlását jellemzi a dielektromos görbén. Ha $\alpha=180^{\circ}$, akkor csak egy karakterisztikus frekvencia van jelen, és az 
illesztett kör középpontja az x-tengelyen helyezkedik el. Ha $\alpha<180^{\circ}$, akkor ez egy szélesebb karakterisztikus frekvencia eloszlást jelez.

A veszteségi csúcs: Ez a paraméter adja meg a veszteségi tényező maximumát a MaxwellWagner relaxáció tartományában. Közvetlen kapcsolatban áll $\alpha$-val, hiszen a karakterisztikus frekvenciák szélesebb eloszlása csökkenti a veszteségi tényező maximum értékét.

Az a hipotézisem, hogy a meghatározható paraméterek közül a húrhossz a legalkalmasabb a Maxwell-Wagner relaxáció jellemzésére a gabonaminták dielektromos görbéjében.

\subsection{DIELEKTROMOS POLARIZÁCIÓ FELSŐ HATÁRÁNAK BECSLÉSE}

Dolgozatomban a gabonák spektrumaiban megfigyelhető két fó vezetési hatás az elektród polarizáció és a Maxwell-Wagner relaxáció dielektromos spektrumra gyakorolt hatását vizsgáltam meg a különböző zavaró tényezők függvényében. Felmerült a kérdés, hogy megbecsülhető-e egy olyan elméleti felső határ, amelynél nagyobb relatív dielektromos állandóról biztonsággal kijelenthető, hogy nem a vízmolekulák orientációjából származik. Nelson és Stetson (1976) mutatott rá arra, hogy a gabonák kis frekvenciákon mért relatív dielektromos állandó értéke túl nagy ahhoz, hogy azt a bipoláris vízmolekulák reorientációja okozza. Véleményük szerint a jelenség feltételezhetően a vezetési hatások miatt jön létre. Funk (2001) a Landau-Lifshitz, Looyenga keverékekre vonatkozó egyenletének (13) használatával az alábbi módon megbecsülte azt a legnagyobb értéket, amennyivel a vízmolekulák orientációja járul hozzá a gabonaminta mért relatív dielektromos állandójához:

$$
\varepsilon_{\text {keverék }}^{\frac{1}{3}}=v_{1} \cdot \varepsilon_{1}^{\frac{1}{3}}+v_{2} \cdot \varepsilon_{2}^{\frac{1}{3}} \rightarrow \varepsilon_{\text {keverék }}=\left(v_{1} \cdot \varepsilon_{1}^{\frac{1}{3}}+v_{2} \cdot \varepsilon_{2}^{\frac{1}{3}}\right)^{3}
$$

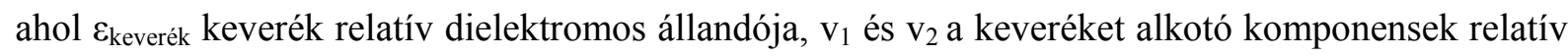
térkitöltése, $\varepsilon_{1}$ és $\varepsilon_{2}$ a komponensek relatív dielektromos állandója. Alkalmazva a (13) egyenletet egy nedves gabonaszemre, ami felfogható egy száraz, nem porózus, szerves anyag és a víz keverékeként:

$$
\varepsilon_{\text {nedves mag }}=\left(\varepsilon_{\text {víz }}^{\frac{1}{3}} \cdot \frac{M \cdot \rho_{\text {száraz mag }}}{M \cdot\left(\rho_{\text {száraz mag }}-1\right)+1}+\varepsilon_{\text {száraz mag }}^{\frac{1}{3}} \cdot \frac{(1-M)}{M \cdot\left(\rho_{\text {száraz mag }}-1\right)+1}\right)^{3}
$$

ahol $\varepsilon_{\text {nedves mag }}$ és $\varepsilon_{\text {száraz mag }}$ a nedves és a száraz gabonaszem relatív dielektromos állandója, $\varepsilon_{\text {víz }}$ a víz

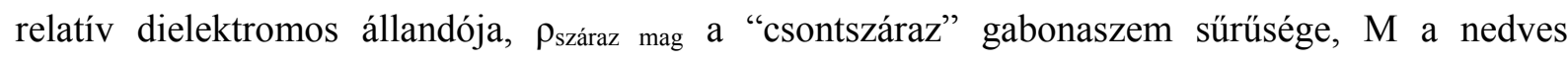
gabonaszem nedvességtartalma. A nedves mag relatív dielektromos állandója becsülhető az irodalmi adatokból. A víz sürüsége $1 \mathrm{~g} / \mathrm{ml}$ és relatív dielektromos állandója $25^{\circ} \mathrm{C}$-on 78,5 . A száraz 
gabonaszemek sürűsége általában 1,0-1,5 g/ml és az úgynevezett csontszáraz gabona relatív dielektromos állandója 2-3.

Az előbbi összefüggést felírva egy nedves gabonaszemekből és a levegő keverékéből álló gabonamintára (37) (felhasználva, hogy a levegő relatív dielektromos állandója 1 és sürüsége a keverékben megközelítően 0 ):

$$
\varepsilon_{\text {gabona minta }}=\left[v_{\text {önm }} \cdot\left(\varepsilon_{\text {víz }}^{\frac{1}{3}} \cdot \frac{M \rho_{\text {száraz mag }}}{M \cdot\left(\rho_{\text {száraz mag }}-1\right)+1}+\varepsilon_{\text {száraz mag }}^{\frac{1}{3}} \cdot \frac{(1-M)}{M \cdot\left(\rho_{\text {száraz mag }}-1\right)+1}-1\right)+1\right]^{3}
$$

ahol $\varepsilon_{\text {gabonaminta }}$ a teljes gabonaminta (nedves gabonaszemek és a levegő)relatív dielektromos állandója, $v_{\text {önm }}$ a mintában az nedves gabonaszemek össztérfogata. Az így kapott összefüggéssel számolt értéknél nagyobb (mért)relatív dielektromos állandó nem magyarázható csak a poláris vízmolekulák forgásával. 


\section{EREDMÉNYEK}

Az eredmények első része a gabona dielektromos spektrumának tulajdonságait, és azok leírását tartalmazza. A második részben a tesztcellában lévő gabona halmaztömörödöttségét befolyásoló tényezőket, különösképpen a nyomás hatását vizsgálom meg, több oldalról. Végezetül az inhomogén nedvességeloszlással kapcsolatos eredményeket mutatom be.

\subsection{A DIELEKTROMOS SPEKTRUM TULAJDONSÁGAI 100 MHZ ALATT}

\subsubsection{A szója dielektromos spektruma}

A dielektromos spektrumok jellemzéséhez 12 különbözö, 9,25 - 17,45 \% nedvességtartalmú szója minta dielektromos jellemzőit mértem meg $100 \mathrm{~Hz}$-től $10 \mathrm{MHz}$-ig terjedő frekvenciatartományban az UGMA tesztcellával. Az eredmények a 28. ábrán láthatók.
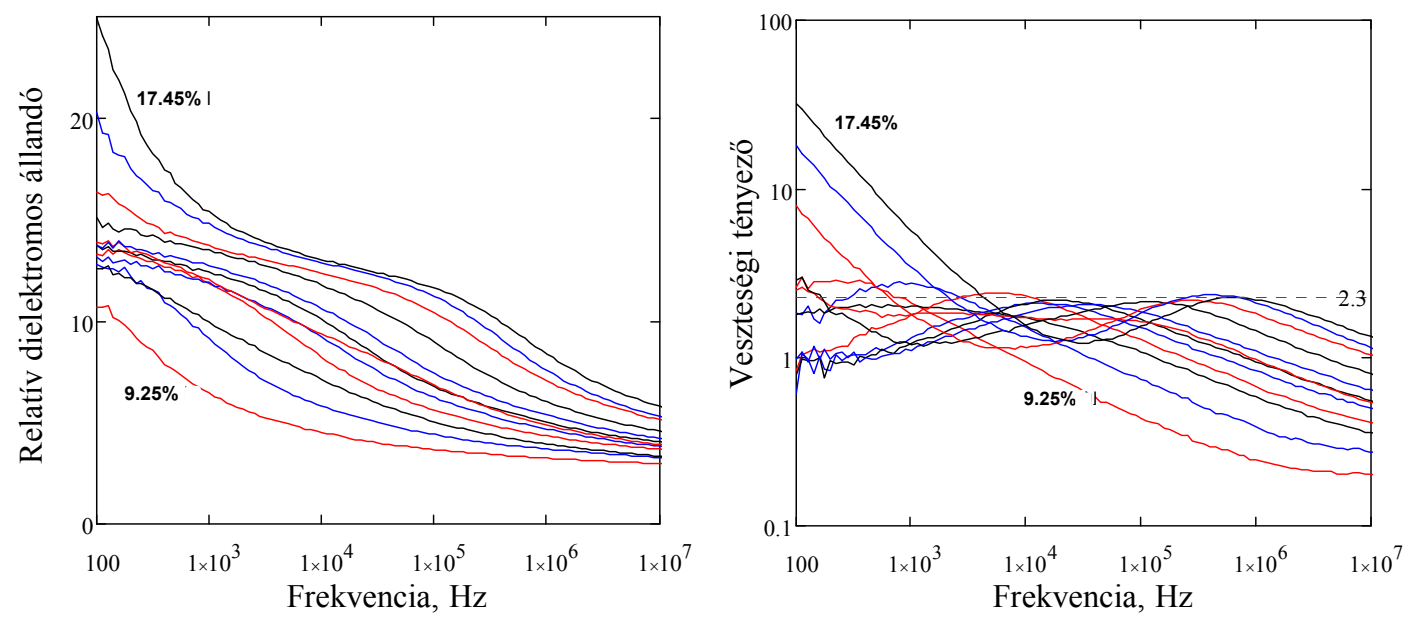

28. ábra A relatív dielektromos állandó és a veszteségi tényező frekvencia függése 9,25 - 17,45 \% közötti nedvességtartalmú szója minta esetén.

Mindkét dielektromos jellemzőről megállapítható, hogy a görbéken látható "hullám” a kis frekvenciákról eltolódik a nagyobb frekvencia értékek felé, ahogy a minta nedvességtartalma növekszik. A relatív dielektromos állandó értéke adott nedvességtartalmon monoton csökken a frekvencia növekedésével, azonban a minta nedvességtartalmának növekedésével monoton nő. A veszteségi tényező lokális minimumának és maximumának helye mintáról-mintára változik a frekvencia függvényében, de lokális minimumának és maximumának értéke minden mintánál közel ugyanakkora. A dielektromos görbék elemzése szempontjából a helyi maximum értéknek van jelentősége, amely a Maxwell-Wagner relaxációt jelző veszteségi csúcs. A veszteségi görbéken a lokális maximumok nagysága a nedvességtartalomtól függetlenül $\approx 2,3$. 
A 29. ábrán az előbbi 12 szója minta relatív dielektromos állandóját ábrázoltam a minták szárítószekrénnyel meghatározott nedvességtartalmának függvényében 6 különböző frekvencián, és az adott frekvenciához tartozó mérési pontokra egyenest illesztettem.
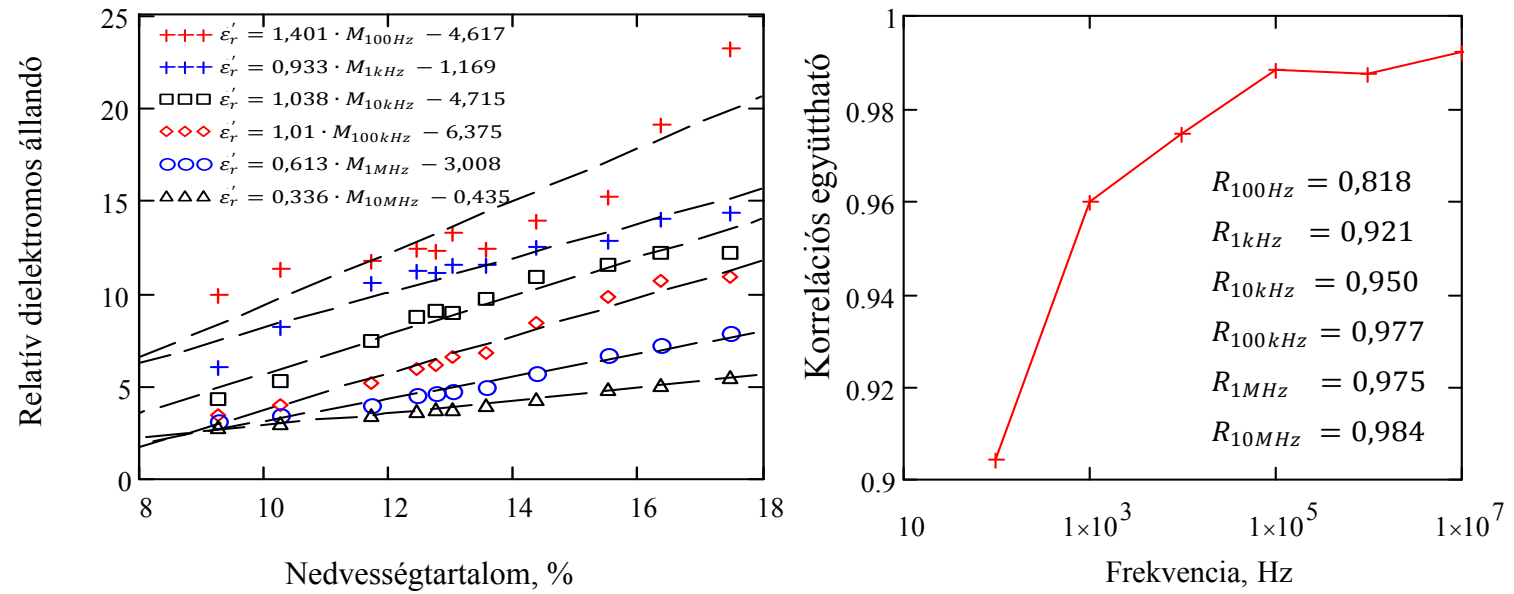

29. ábra A 9,25 - 17,45 \% közötti nedvességü szójákra illesztett egyenesek és a korrelációs együtthatók a frekvencia függvényében.

$\mathrm{Az}$ ábrán jól látható, hogy az $\mathrm{R}$ értéke a frekvencia növekedésével nő. $\mathrm{A}$ nagyobb frekvenciák felé haladva a relatív dielektromos állandó nedvességfüggése egyre lineárisabb, ahogy ez az irodalomból jól ismert.

A 30. ábrán szaggatott vonallal ábrázoltam az adott frekvenciához tartozó, a (37) egyenlettel becsült relatív dielektromos állandót (mely feltételezhetően a víz polarizációjából származik) ábrázoltam. A számításhoz felhasználtam az alábbiakat: $\varepsilon_{\mathrm{viz}}=78,5, \mathrm{v}_{\mathrm{önm}}=0,7, \rho_{\mathrm{száraz} \mathrm{mag}}=1,4 \mathrm{~g} / \mathrm{ml}$ és $\varepsilon_{\text {száraz mag }}=2$. 

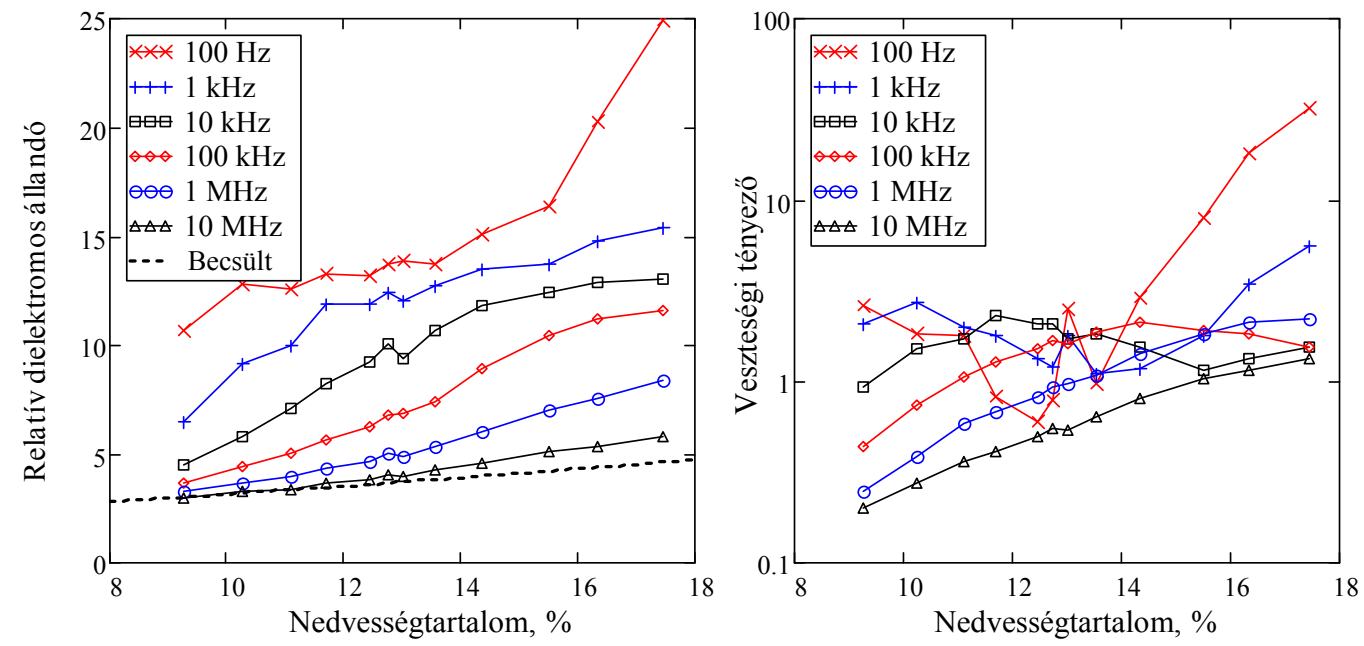

30. ábra A relatív dielektromos állandó és a veszteségi tényező függése minta nedvességtartalmától különböző frekvenciákon és a feltételezhetően a vízmolekulák polarizációjából származó becsült felső határral (szaggatott vonal).

A becsült értéknél nagyobb relatív dielektromos állandó a vezetési hatások (elektród polarizáció, Maxwell-Wagner relaxáció) eredményeképpen jön létre. Ezek a hatások a kisebb frekvenciákon nagyobb mértékben járulnak hozzá a relatív dielektromos állandó értékének növekedéséhez.

\subsubsection{Argand ábrázolás}

A gabonák dielektromos spektrumai nedvességtartalom függőek, így várhatóan az Argand görbéik is az adott nedvességre jellemzőek lesznek. Feltételezésem bizonyítására 12 szója és 8 kukorica mintát ábrázoltam Argand diagramon. Az így kapott görbékre körívet és ha lehetett egyenest illesztettem, és meghatároztam az illesztett paramétereket. A következő ábrákon a szója (31. ábra) és a kukorica (32. ábra) minták Argand ábrái láthatók az illesztett körívvel és egyenessel. 

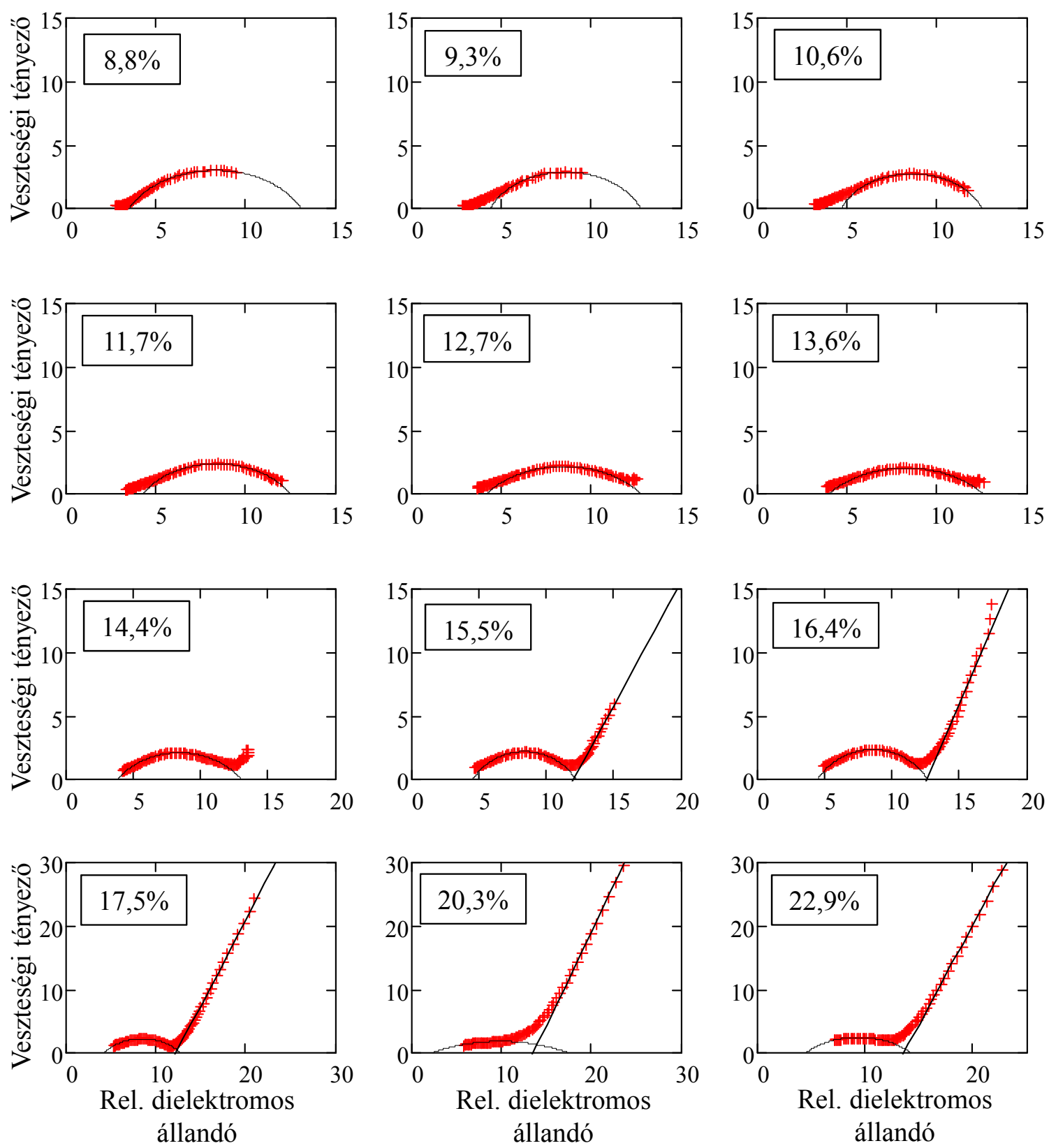

31. ábra A szója minták Argand görbéi 

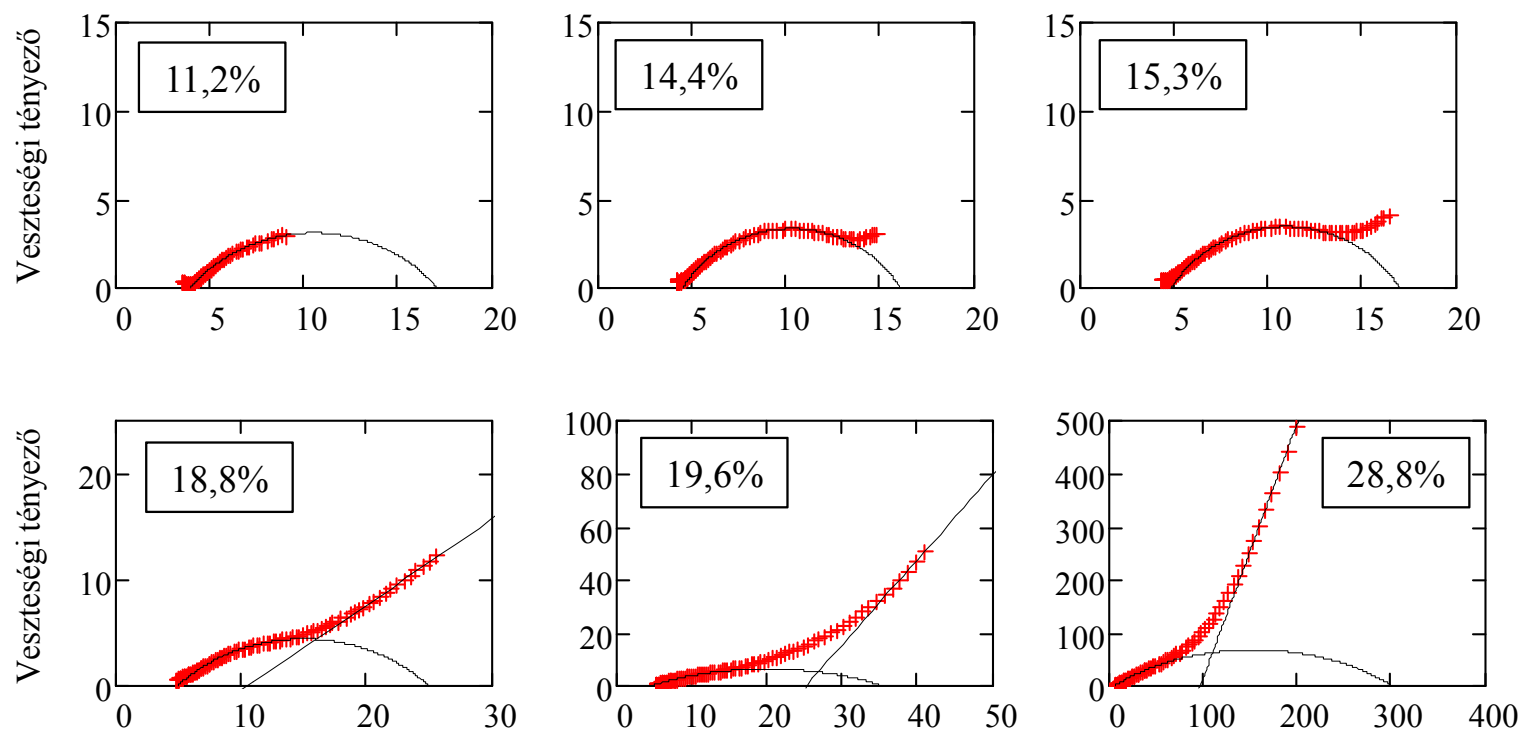

Rel. dielektromos állandó

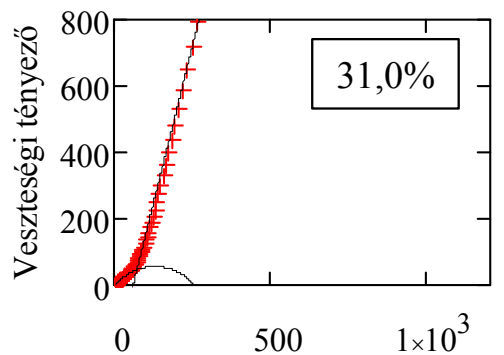

Rel. dielektromos állandó

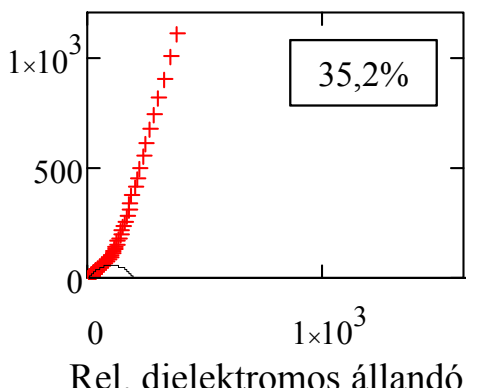

32. ábra A kukorica minták Argand görbéi

A szója és a kukorica minták Argand ábrájuk képe szerint 3 fő csoportra oszthatók. Az első csoportban, jellemzően a száraz gabonáknál, a Maxwell-Wagner relaxációra jellemző körív jelenik meg. Majd a nedvességtartalom növekedésével a görbe jobb oldalán egyre jobban kirajzolódik az elektród polarizációt jelző egyenes. A harmadik csoportba a nedves minták tartoznak, amelyeknél a Maxwell-Wagner körív egyre kisebb lesz, a kukoricáknál szinte el is tünik, míg az egyenes egyre határozottabbá válik, az elektród polarizáció dominálja a görbéket, mint például a 28,8\%-nál nedvesebb kukoricáknál. A nedves kukoricák Argand görbéin a Maxwell-Wagner körív fizikailag értelmezhetetlenné vált, hiszen ekkor a húrhossz, amely a relatív dielektromos állandó csökkenéssel egyenlő a relaxációt jellemző frekvenciatartományban százas nagyságrendű lett.

Az Argand ábrákban a kis frekvenciákon megjelenő lineáris szakasz az elektród polarizáció jelenlétét jelzi, amely egyre hosszabb és határozottabb lett a minta nedvességtartalmának növekedésével. A görbe ezen része nem modellezhető körívvel, azaz ideális ellenállásokkal és kapacitásokkal. Az elektród polarizáció a dielektromos görbéken az állandó fázisú elem megjelenéséről ismerhető fel. A relatív dielektromos állandó és a veszteségi tényező aránya 
jellemzően állandó abban a frekvenciatartományban ahol az elektród polarizáció domináns a dielektromos spektrumban.

A szója és kukorica minták Argand görbéit összehasonlítva megállapítható, hogy míg a szója mintákon fokozatosan válik a dominánssá az elektród polarizáció, addig a kukorica minták görbéin ez a dominancia hirtelen jelenik meg a nedvességtartalom növekedésével. E jelenség oka a kukorica és szója szemek különböző alakjában és összetételében keresendő.

\subsection{AZ LLL SÜRÜSÉGKORREKCIÓ MÜKÖDÉSE 100 MHZ ALATT}

Ebben a fejezetben az LLL sürüségkorrekció hatékonyságát vizsgáltam meg két eltérő, a gabonaminta tömörödöttségét okozó hatásnál, úgymint a rázás és a terményoszlop tetején alkalmazott nyomás. A vizsgálatokba két hengerkondenzátor tesztcellát és két párhuzamos falú tesztcellát (GAC és UGMA) vontam be, melyek a kereskedelmi forgalomban nemzetközileg elterjedt dielektromos nedvességmérőkben is megtalálhatók. Az általam vizsgált frekvenciatartomány, magába foglalja a nedvességmérésben kiemelten fontos 1-20 MHz-es tartományt. Az LLL sürüségkorrekció müködését legkönnyebben ugyanazon minta két különböző tömörödöttségét elöidéző hatás összehasonlításával tehetjük meg. Mivel a relatív dielektromos állandók közötti különbségek viszonylagosan nagyok voltak, a relatív dielektromos állandó hányados értékét vettem az összehasonlítások alapjául. A különböző betöltési módok vizsgálatánál a relatív dielektromos állandó hányadost a nagyobb tömörödöttséget okozó lassú betöltés és ugyanazon minta gyors betöltéssel mért relatív dielektromos állandójának a hányadosából képeztem. A nyomás hatásának vizsgálatakor a relatív dielektromos állandó hányados az adott nyomáson mért és ugyanazon minta gyors betöltéssel mért relatív dielektromos állandójának a hányadosa. Az eredmények értékelése mindkét esetben ugyanaz. Ha az LLL sürüségkorrekció jól müködött az adott frekvencián, akkor a hányados 1, ami a különböző halmaztömörödöttségekböl eredő hibák teljes kiküszöbölését jelenti. A betöltések és a nyomás vizsgálatánál egyaránt a nagyobb halmaztömörödöttséget okozó esetet osztottuk a kisebbel. Így ha hányados értéke nagyobb, mint 1, akkor ez a gyakorlatban annyit jelent, hogy a számított nedvességtartalom értéke nagyobb lesz, mint a tényleges nedvességtartalma a mintának. Ha a hányados értéke kisebb mint egy, akkor a minta nedvességtartalmát alábecsüljük a valóshoz képest. Az általam használt nedvesség kalibrációkkal a relatív dielektromos állandó értékében $\pm \Delta \varepsilon=0,1$ eltérés kukorica esetén körülbelül $\pm \Delta \mathrm{M}=0,35 \%$ eltérést okoz a számított nedvességtartalom értékében, míg ugyanez az érték szója esetén $\pm \Delta M=0,21 \%$ eltérést okoz. 
Az eredményeket az egyes tesztcellákra lebontva közlöm. Az alkalmazott terhelőerő minden tesztcellánál $10 \mathrm{~N}$ és $20 \mathrm{~N}$ volt, ami azonban a nyomott felület nagyságának változása miatt különböző nyomásokat jelent.

\subsubsection{GAC tesztcella}

\subsubsection{Az LLL sürüségkorrekció és a betöltések vizsgálata}

A 33. ábra a GAC tesztcellával mért 13,5 \%-31,8 \% nedvességtartalom közötti kukorica minták relatív dielektromos állandó hányadosát mutatja meg a frekvencia függvényében.
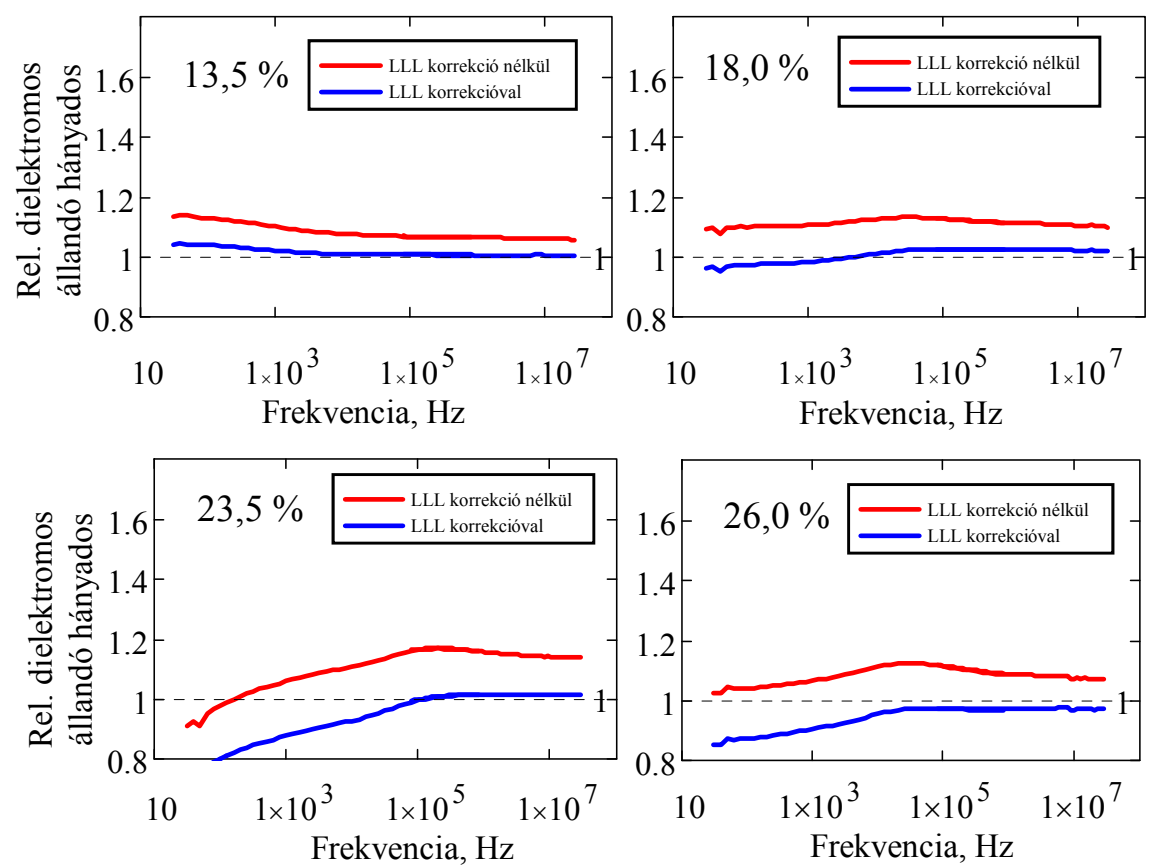

33. ábra A 13,5 \%-26,0 \% nedvességtartalmú kukorica minták relatív dielektromos állandó hányadosai ( $\varepsilon_{\text {lassú }} / \varepsilon_{\text {gyors }}$ ) a frekvencia függvényében, LLL sűrüségkorrekció előtt és után, a GAC tesztcellával mérve

Az LLL sűrüségkorrekció alkalmazása után a hányados értéke $\pm 0,03$ eltéréssel közelíti meg az 1-et $100 \mathrm{kHz}$ felett minden mintánál. A $100 \mathrm{kHz}$ alatti frekvenciákon a 18,0 \%-nál nagyobb nedvességtartalmú minták relatív dielektromos hányados értéke a korrekció után egyre kisebb lett. Azonban az ideális esethez képest, amikor a hányados értékére 1-et kapunk eredményül, a maximális eltérés -0,2. Megállapíthatjuk, hogy az LLL sürüségkorrekció hatékony volt.

\subsubsection{Az LLL sürüségkorrekció és a nyomás vizsgálata}

Megvizsgáltam az LLL sürüségkorrekció alkalmazhatóságát, a tesztcellában lévő gabonahalmaz tetején nyomást alkalmazva. A terhelést folyamatosan növeltem a kívánt nyomás 
értékek eléréséig. A dielektromos méréseket nyomás alatt végeztem el. A 34. ábra a relatív dielektromos állandó hányadost mutatja $\mathrm{P} 1=2,8 \mathrm{kPa}$ és $\mathrm{P} 2=5,6 \mathrm{kPa}$ nyomáson az LLL sürüségkorrekció alkalmazása előtt és után a frekvencia függvényében.
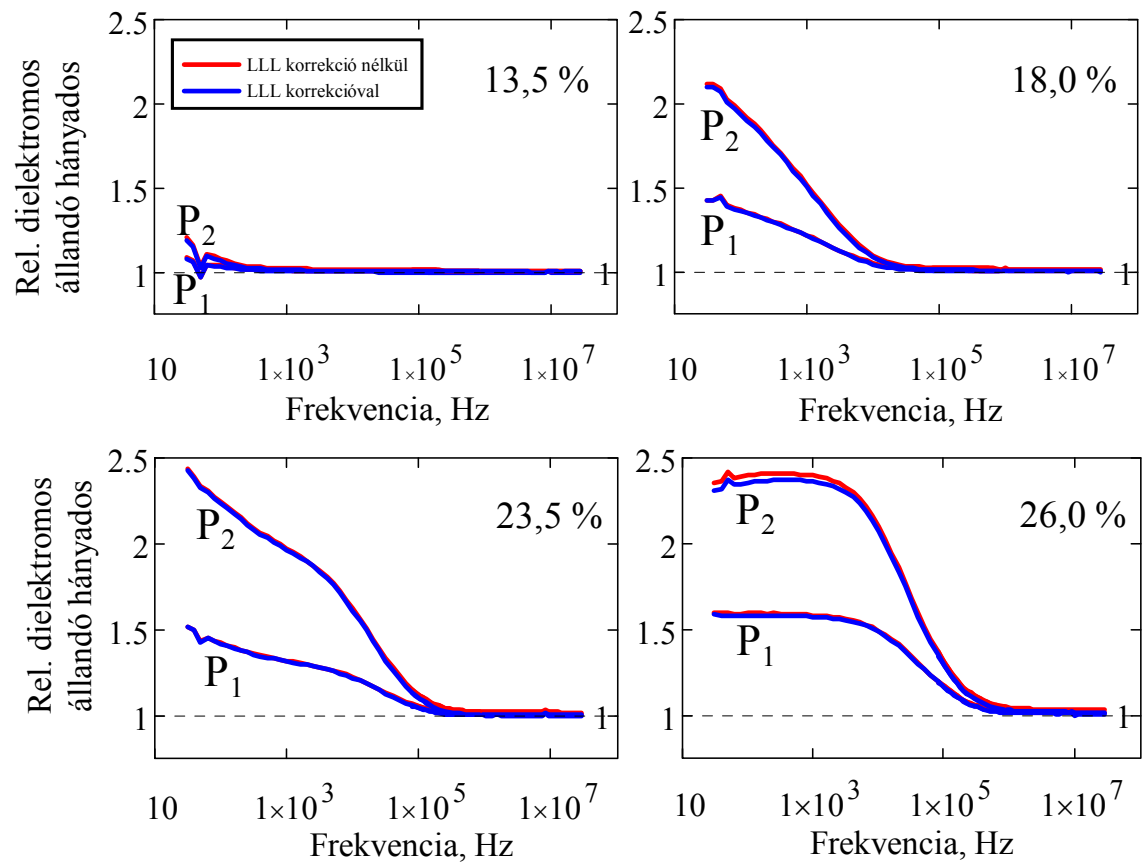

34. ábra A 13,5 \%-26,0 \% nedvességtartalmú kukorica minták relatív dielektromos állandó hányadosai, $\varepsilon_{(\mathrm{P} 1)} / \varepsilon^{\prime}$ gyors és $\varepsilon^{\prime}{ }_{(\mathrm{P} 2)} / \varepsilon^{\prime}{ }_{\text {gyors }}$, a frekvencia függvényében, LLL sürüségkorrekció előtt és után, a GAC tesztcellával mérve; $\mathrm{P} 1=2,8 \mathrm{kPa}$ és $\mathrm{P} 2=5,6 \mathrm{kPa}$

Az LLL sűrüségkorrekció alkalmazása nem okoz jelentős változást a hányadosok értékeiben. A 13,5\%-nál nedvesebb minták relatív dielektromos állandó hányados értéke nő a frekvencia csökkenésével és a nyomás nagyságának növekedésével $100 \mathrm{kHz}$ alatt, azonban az LLL sürüségkorrekció alkalmazása előtt és után a dielektromos görbe gyakorlatilag változatlan.

Mekkora sűrüségkülönbség jön létre a különböző betöltési módok és a terhelés hatására? A 35. ábrán a rázva és gyors betöltési módokkal, és a terhelés következtében létrejött minta sürüségek láthatók. 

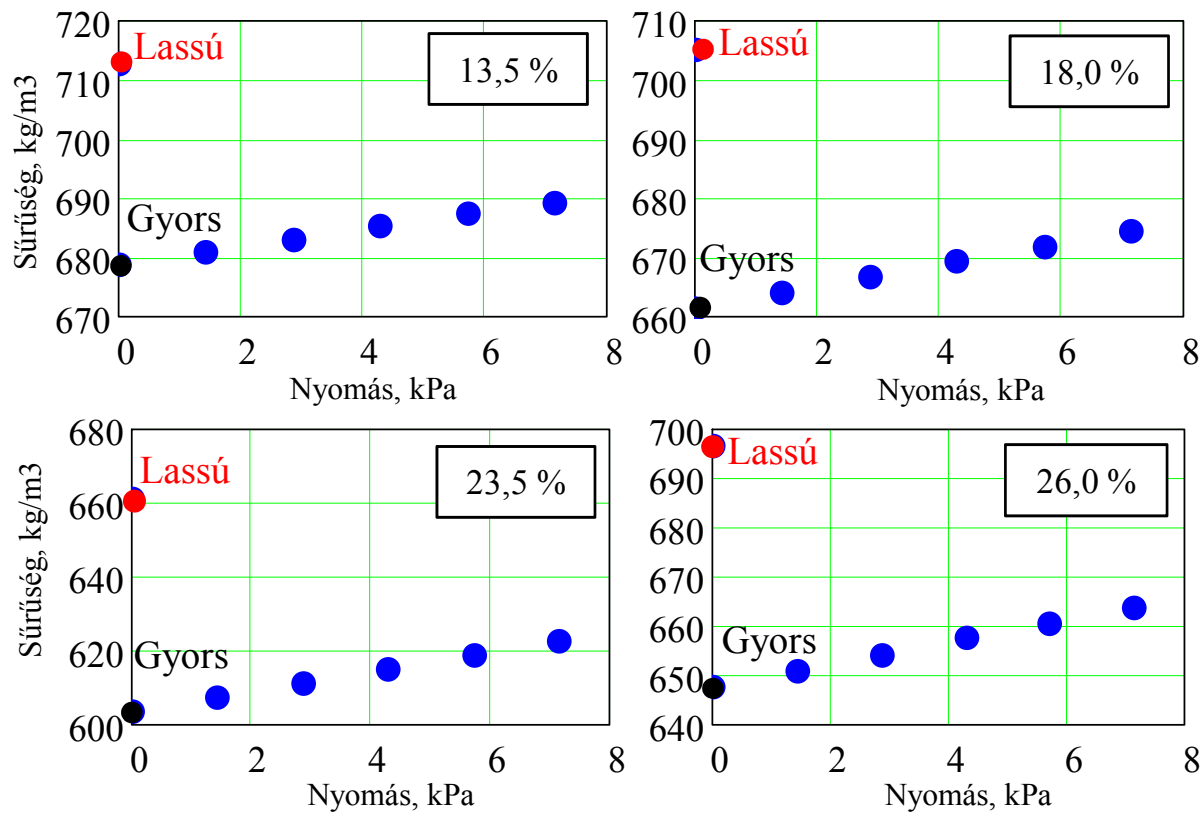

35. ábra A 13,5 \% és 26,0 \% közötti nedvességtartalmú minták sürüsége a nyomás függvényében a

különböző betöltési módok és nyomások hatására a GAC tesztcellában. Piros pont jelöli a lassú betöltésű, fekete pont a gyors betöltésű minta sürüségét. Kékkel jelöltem a különböző nyomásokhoz tartozó sürüség értékeket.

A lassú és gyors betöltési mód közötti sürüség különbsége közel háromszorosa a gyors betöltés és a legnagyobb nyomás hatására létrejött sürüségek különbségének, függetlenül a minta nedvességtartalmától.

Összehasonlítva a 33. és a 34. ábrán található különböző betöltések és a nyomások alkalmazása után kapott relatív dielektromos hányados görbéket ugyanazon nedvességtartalmú mintán megállapíthatjuk, hogy bár a nyomás a tesztcellában lévő gabona halmazt tömöríti, hasonlóan a rázáshoz, de a relatív dielektromos állandó hányadosok görbéi jellegükben eltérnek a rázott minta dielektromos hányados görbéitől. Míg a különböző betöltésekből eredő különböző minta sürüséget teljesen vagy részben korrigálta az LLL sürüségkorrekció, addig a mintákban a nyomás hatására létrejött, eltérő halmaztömörödöttségek korrigálására hatástalannak bizonyult.

\subsubsection{UGMA tesztcella}

\subsubsection{Az LLL sürüségkorrekció és a betöltések vizsgálata}

A 36. ábrán az UGMA tesztcellával mért relatív dielektromos állandó hányadosok láthatók a frekvencia függvényében 11,2 \% és 28,8 \% közötti nedvességtartalmú kukorica esetén. 

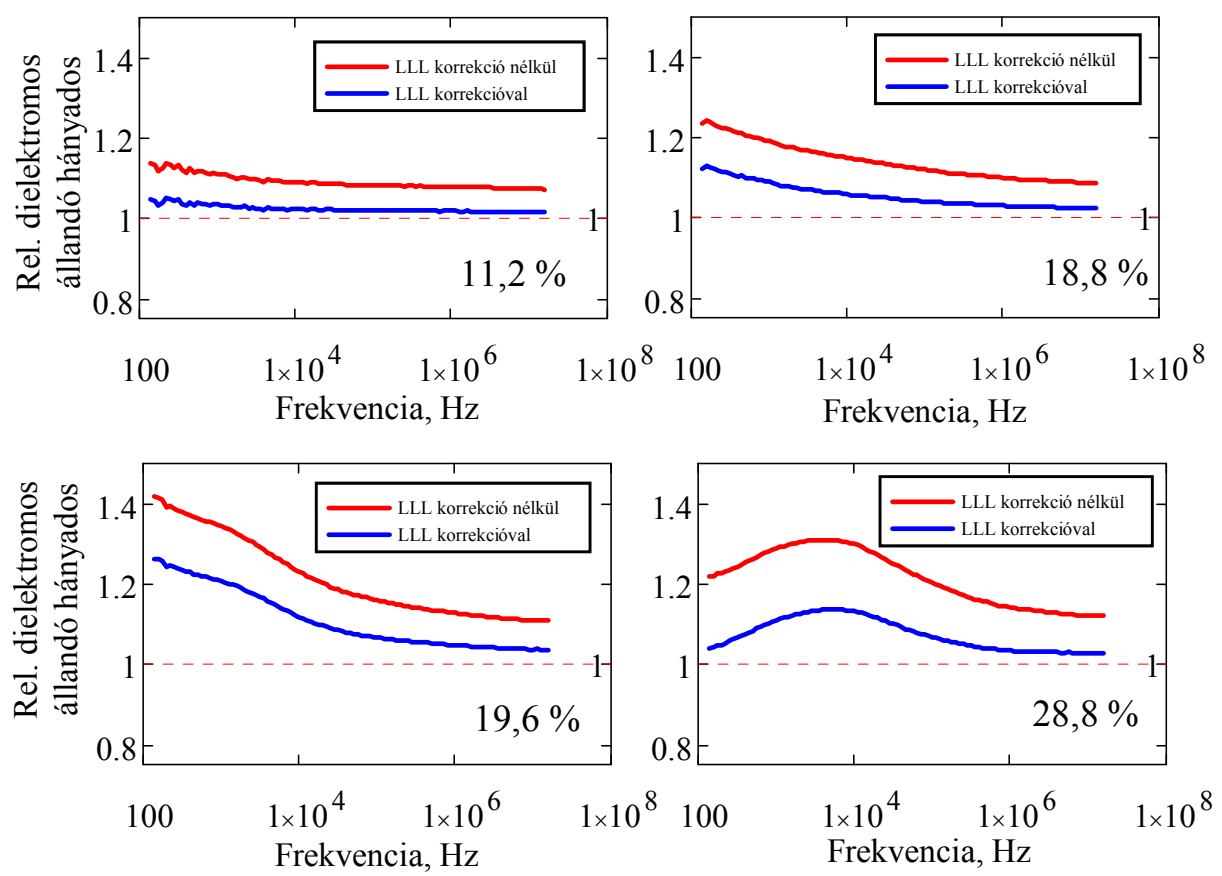

36. ábra A 11,5 \%-28,8 \% nedvességtartalmú kukorica minták relatív dielektromos állandó hányadosai ( $\varepsilon_{\text {lassú }} / \varepsilon_{\text {gyors }}$ ) a frekvencia függvényében, LLL sürüségkorrekció előtt és után, az UGMA tesztcellával mérve

A hányadosok értéke a korrekció után $100 \mathrm{kHz}$ felett maximum +0,07 eltéréssel megközelíti az egyet. Az LLL sürüségkorrekció minden esetben csökkenti a relatív dielektromos állandó hányados értékét azonban a mérőfrekvencia csökkenésével és a minta nedvességtartalmának növekedésével csökken a sürüségkorrekció hatékonysága. Bár a 19,6 \% és 31,0 \% nedvességü kukorica minták esetén a sürüségkorrekció közel 1 tizeddel csökkenti a relatív dielektromos állandó hányados értékét $100 \mathrm{kHz}$ alatt, de a hányados eltérése 1-töl e mintáknál 0,1 - 0,4 közötti érték ebben a frekvenciatartományban.

A görbék jellegéből azt feltételeztem, hogy a korrekció azért bizonyult kevésbé hatékonynak az UGMA tesztcellánál, mert az $1 \mathrm{MHz}$ alatti frekvenciákon megjelenő vezetési hatások, mint az elektród polarizáció és a Maxwell-Wagner relaxáció keveredik a kukoricaszemek orientációjából fakadó hatásokkal. A hipotézist szóján teszteltem. A különböző betöltések relatív dielektromos állandó hányados görbéi 10,6 \% és 16,7 \% közötti nedvességű szójamintákon a 37. ábrán láthatók. 

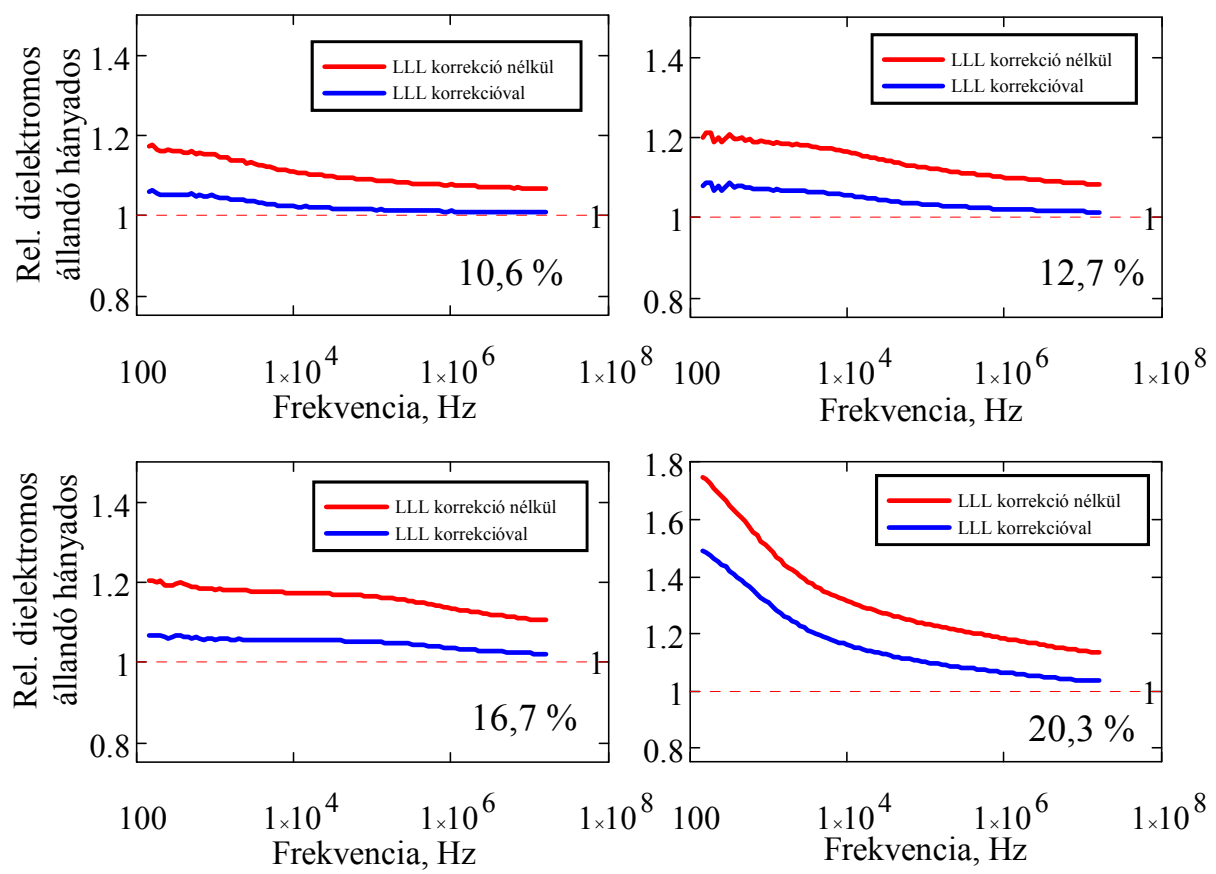

37. ábra A 10,6 \%-20,3\% nedvességtartalmú szója minták relatív dielektromos állandó hányadosai ( $\varepsilon^{\prime}{ }_{\text {lassú }} / \varepsilon_{\text {gyors }}$ ) a frekvencia függvényében, LLL sürüségkorrekció előtt és után, az UGMA tesztcellával mérve

A 37. ábrán látható szója minták a relatív dielektromos állandó hányados értéke sűrüség korrekció után a 0 és $+0,1$ közötti változik a teljes frekvenciatartományban kivéve a 20,3\%-os mintát. Az LLL sürüségkorrekció az általam vizsgált frekvenciatartományban hatékonynak bizonyult az eltérő betöltésekből fakadó sűrüségkülönbségek csökkentésére 16,7 \% nedvességtartalom alatt. A 20,3 \% nedvességü mintánál a görbe meredeken nő a $100 \mathrm{kHz}$ alatti frekvenciákon. A maximális eltérés az ideális korrekciótól + 0,5. Az eredményekböl nem dönthető el egyértelmüen, hogy a hipotézisem a kukorica szemek orientációjára vonatkozóan igaznak bizonyult-e. A kérdés megválaszolásához további vizsgálatok lennének szükségesek, melyek nem e doktori munka tárgya.

\subsubsection{Az LLL sürüségkorrekció és a nyomás vizsgálata}

A 38. ábrán a 11,2\% - 28,8 \% nedvességtartalmú kukorica minták relatív dielektromos állandó hányadosai láthatók a frekvencia függvényében $\mathrm{P} 1=1,8 \mathrm{kPa}$ és $\mathrm{P} 2=3,5 \mathrm{kPa}$ nyomáson: 

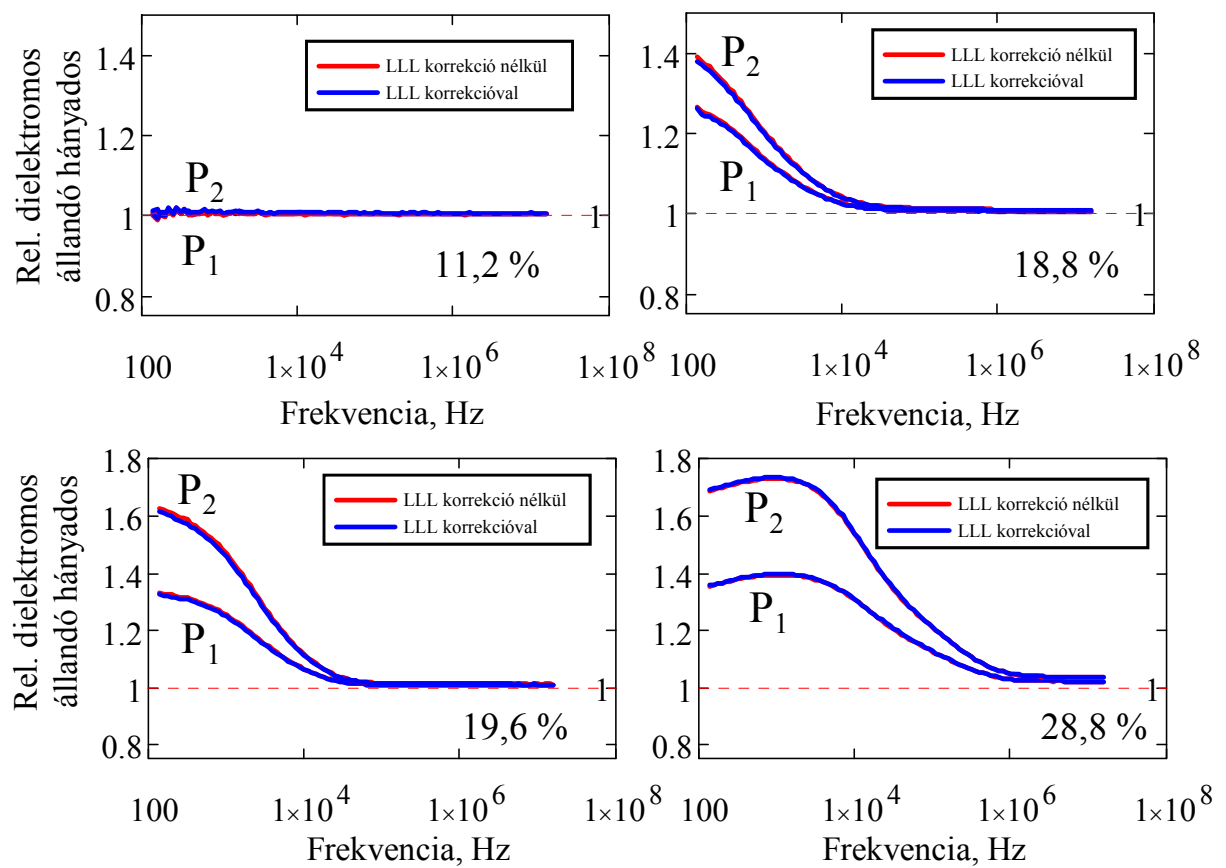

38. ábra A 11,2 \%-28,8 \% nedvességtartalmú kukorica minták relatív dielektromos állandó hányadosai, $\varepsilon^{\prime}{ }_{(\mathrm{P} 1)} / \varepsilon^{\prime}{ }_{\text {gyors }}$ és $\varepsilon^{\prime}{ }_{(\mathrm{P} 2)} / \varepsilon^{\prime}{ }_{\text {gyors }}$, a frekvencia függvényében, LLL sürüségkorrekció elött és után, az UGMA tesztcellával mérve P1 $=1,8 \mathrm{kPa}$ és $\mathrm{P} 2=3,5 \mathrm{kPa}$

A 38. ábrán az LLL sürüségkorrekciónak elhanyagolható a hatása a relatív dielektromos állandó hányados görbéin a teljes frekvenciatartományban függetlenül a kukorica minta nedvességtartalmától és az alkalmazott nyomás nagyságától.

Megvizsgáltam az LLL sürüségkorrekció müködését $\mathrm{P} 1=1,8 \mathrm{kPa}$ és $\mathrm{P} 2=3,5 \mathrm{kPa}$ nyomást alkalmazva 10,6 \% - 20,3 \% nedvességtartalmú szója mintákon is (39. ábra): 

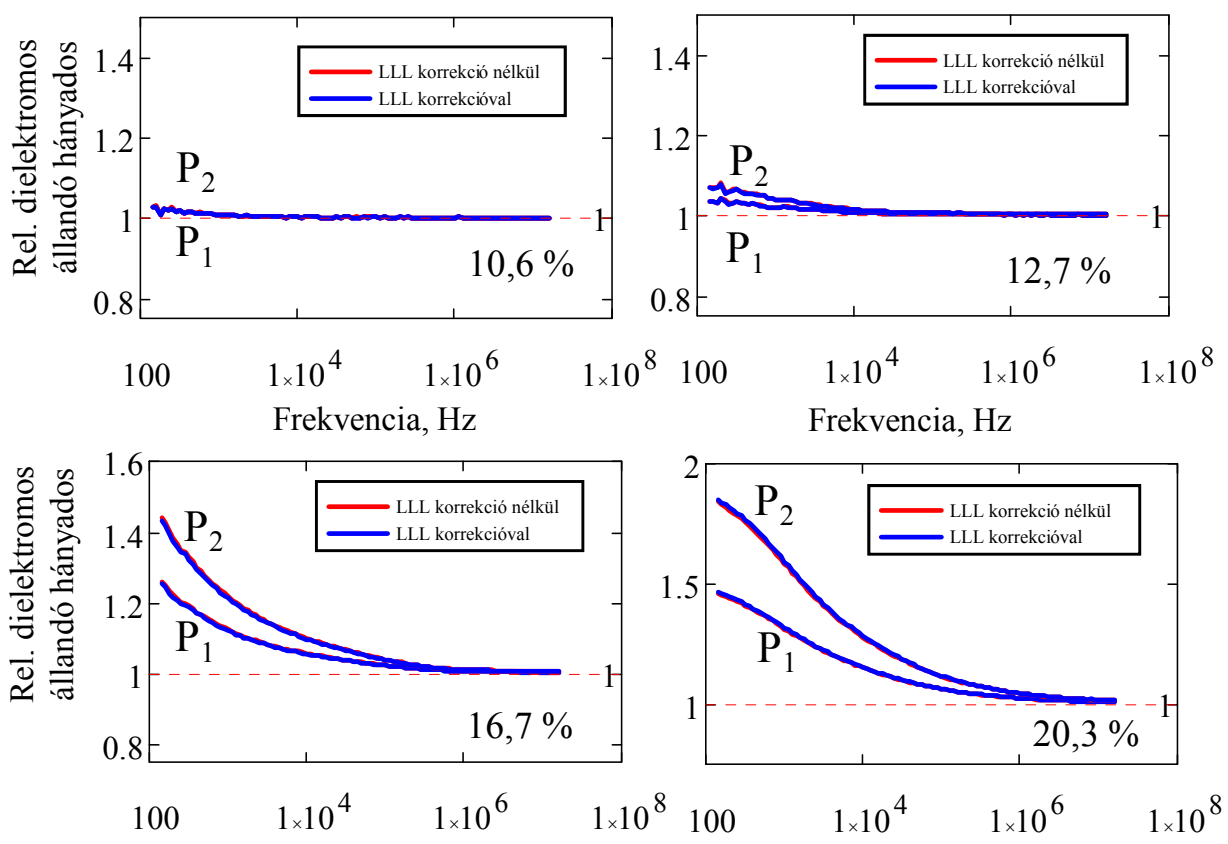

39. ábra A 10,6 \%-20,3 \% nedvességtartalmú szója minták relatív dielektromos állandó hányadosai, $\varepsilon^{\prime}{ }_{(\mathrm{P} 1)} / \varepsilon^{\prime}{ }_{\text {gyors }}$ és $\varepsilon^{\prime}{ }_{(\mathrm{P} 2)} / \varepsilon^{\prime}{ }_{\text {gyors }}$, a frekvencia függvényében, LLL sürüségkorrekció előtt és után, az UGMA tesztcellával mérve, $\mathrm{P} 1=1,8 \mathrm{kPa}$ és $\mathrm{P} 2=3,5 \mathrm{kPa}$

A relatív dielektromos állandó hányados görbékre az LLL sürüségkorrekciónak elhanyagolható a hatása a minta nedvességtartalmától, az alkalmazott nyomás nagyságától és a frekvenciától függetlenül.

\subsubsection{Hengerkondenzátor tesztcella}

Az előzőkből megállapítható, hogy a két párhuzamos falú tesztcellánál az LLL sürüségkorrekció a betöltésekből fakadó eltéréseket kompenzálja. A mintákon nyomást alkalmazva, az így létrejött sürüségkülönbségek kiküszöbölésére az LLL sürüségkorrekció hatástalan. A továbbiakban megvizsgáltam, hogy a tapasztaltak tesztcella specifikusak-e, azaz hasonló következtetésekre jutunk-e, ha tesztcellaként hengerkondenzátort alkalmazunk.

\subsubsection{Az LLL sürüségkorrekció és a betöltések vizsgálata}

A 40. ábrán 16,2 \%-31,8\% nedvességü kukorica minták relatív dielektromos állandó hányados görbéit ábrázoltam, hengerkondenzátort használva tesztcellaként: 

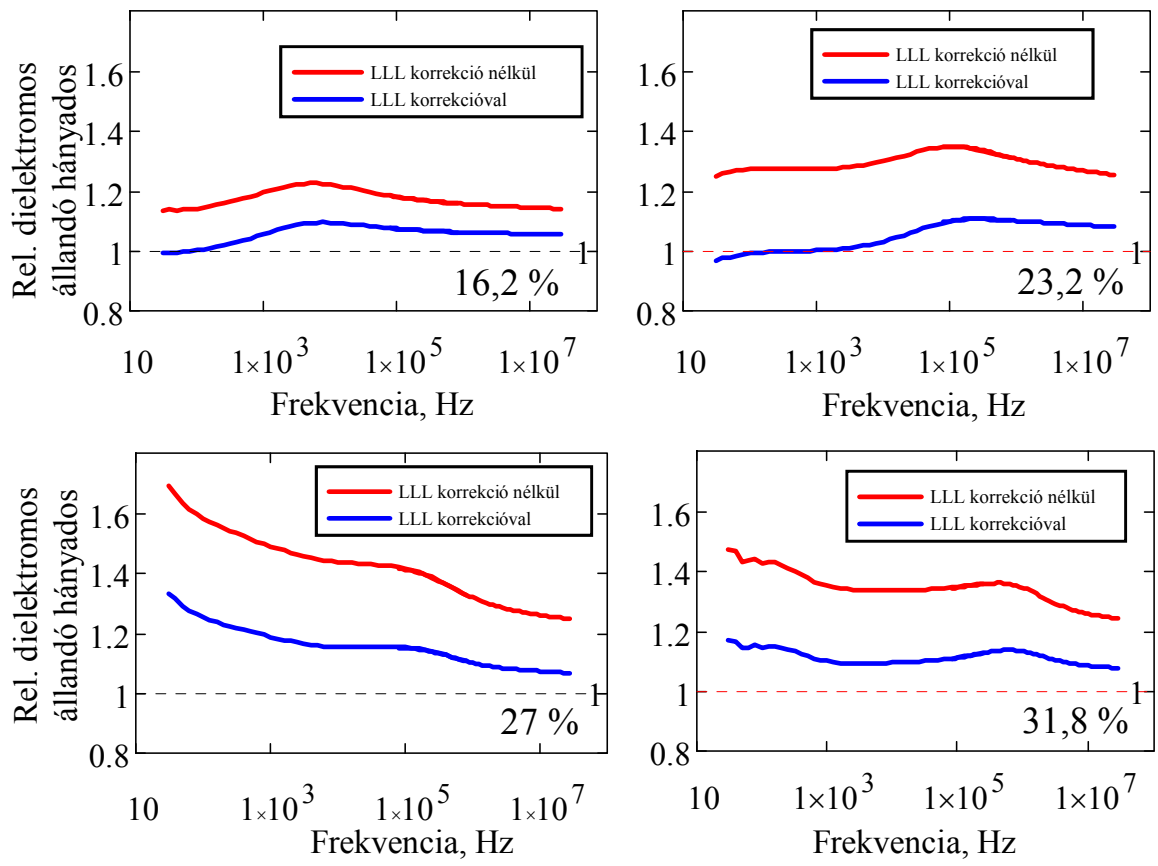

40. ábra A 16,2 \%-31,8 \% nedvességtartalmú kukorica minták relatív dielektromos állandó hányadosai $\left(\varepsilon^{\prime}\right.$ lassú $\left./ \varepsilon_{\text {gyors }}^{\prime}\right)$ a frekvencia függvényében, LLL sürüségkorrekció előtt és után, a hengerkondenzátor tesztcellával mérve

Az LLL sürüségkorrekció jelentős javulást okozott a hányados értékében minden nedvességtartalmon a teljes frekvenciatartományban. A két nedvesebb, $27 \%$ és 31,8 \% nedvességü minták eltérése az 1-től $+0,1$ és $+0,3$ között változik a frekvenciától függően, de sosem éri el az 1-et még $1 \mathrm{MHz}$ frekvencia felett sem. A 16,2 \% és 23,2 \% nedvességü mintáknál a hányados értéke $1 \mathrm{kHz}$ frekvencia alatt $+0,05$ illetve 1 , ami ellentmond az eddig tapasztaltakkal. A GAC és UGMA tesztcelláknál az LLL a relatív dielektromos állandó hányados értékeire $1 \mathrm{MHz}$ frekvencia felett kaptunk közel 1-et és az $1 \mathrm{MHz}$ alatti frekvenciákon az egytől való eltérés nőtt a frekvencia csökkenésével.

\subsubsection{Az LLL sürüségkorrekció és a nyomás vizsgálata}

Megvizsgáltam az LLL sürüségkorrekció hatásosságát $\mathrm{P} 1=1,5 \mathrm{kPa}$ és $\mathrm{P} 2=3,0 \mathrm{kPa}$ nyomáson 16,2 - 31,8 \% nedvességü kukorica mintákon (41. ábra). 

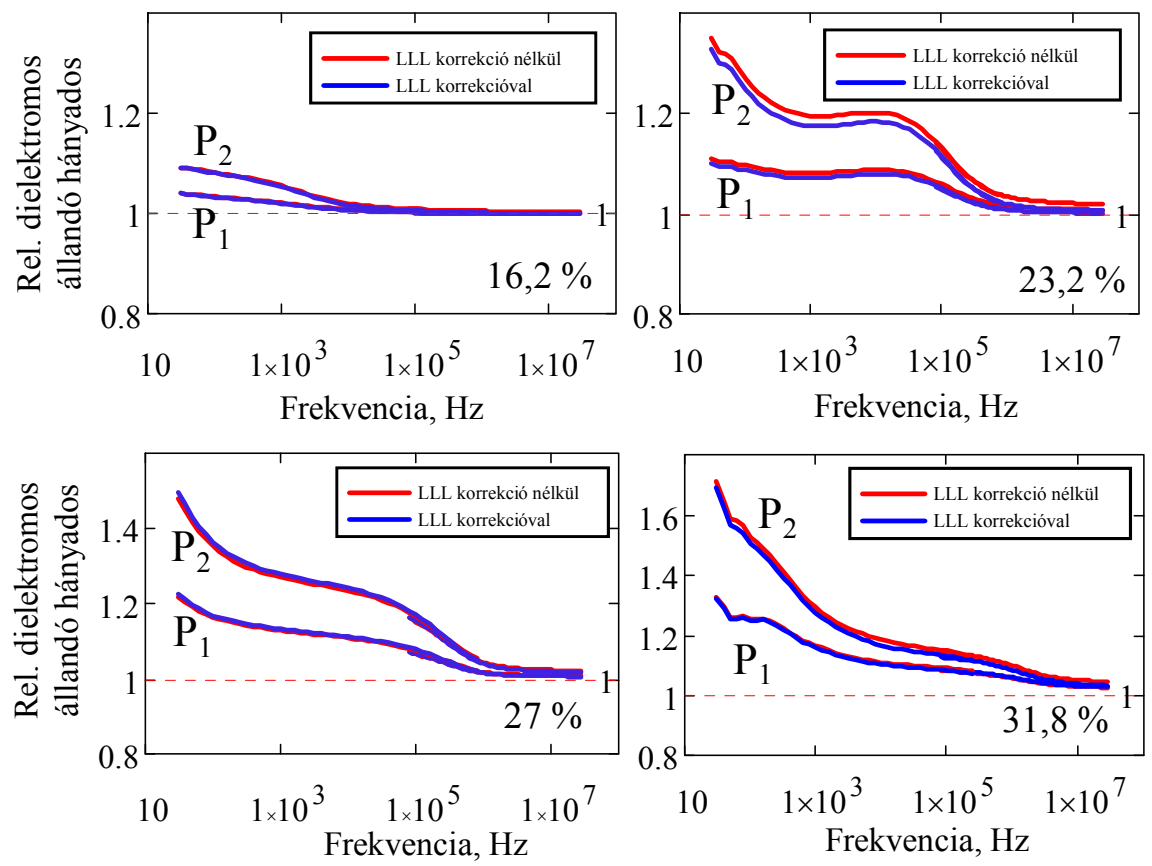

41. ábra A 16,2 \% és 31,8 \% nedvességü kukorica minták relatív dielektromos állandó hányadosai, $\varepsilon_{(\mathrm{P} 1)} / \varepsilon^{\prime}{ }_{\text {gyors }}$ és $\varepsilon^{\prime}{ }_{(\mathrm{P} 2)} / \varepsilon^{\prime}$ gyors, a frekvencia függvényében, LLL sürüségkorrekció előtt és után, a hengerkondenzátor tesztcellával mérve. $\mathrm{P} 1=1,5 \mathrm{kPa}$ és $\mathrm{P} 2=3,0 \mathrm{kPa}$

A relatív dielektromos állandó hányados görbéi ugyanazt a tendenciát mutatják, amint azt a GAC és UGMA tesztcelláknál tapasztaltunk: Az LLL sürüségkorrekciónak elhanyagolható a hatása a relatív dielektromos állandó hányados görbékre minden nedvességtartalmon és frekvencián.

Mindezek ahhoz a feltételezéshez vezettek, hogy a tesztcellánál a különböző betöltések esetén a jelenségért nem az LLL sürüségkorrekció felelös. A hengerkondenzátor tesztcellánál a számításokhoz a gabona átlagsürüségét használtam a teljes térfogatra vonatkoztatva. Ezáltal a tesztcella elektromosan aktív részében pontatlanná vált a sürüség meghatározás, mivel más a sürüség a középső elektród felett és a tesztcella mellett. Így a különböző betöltés miatt létrejött sürüség különbség a tesztcella elektromosan aktív zónájában jóval nagyobb lett, mint a központi elektród feletti részben, amelynek csekély hatása van a dielektromos mérésre. (A hengerkondenzátor központi elektródja 72 milliméterrel alacsonyabb volt, mint a külső elektród magassága.). Feltevést igazolandó a hengerkondenzátor tesztcella módosítása (központi elektród meghosszabbítása) után megismételtem a méréseket. 


\subsubsection{Módosított hengerkondenzátor tesztcella}

\subsubsection{Az LLL sürüségkorrekció és a betöltések vizsgálata}

A központi elektród meghosszabbításával módosított hengerkondenzátor tesztcellával végzett a mérések eredményei a 42. ábrán láthatók:
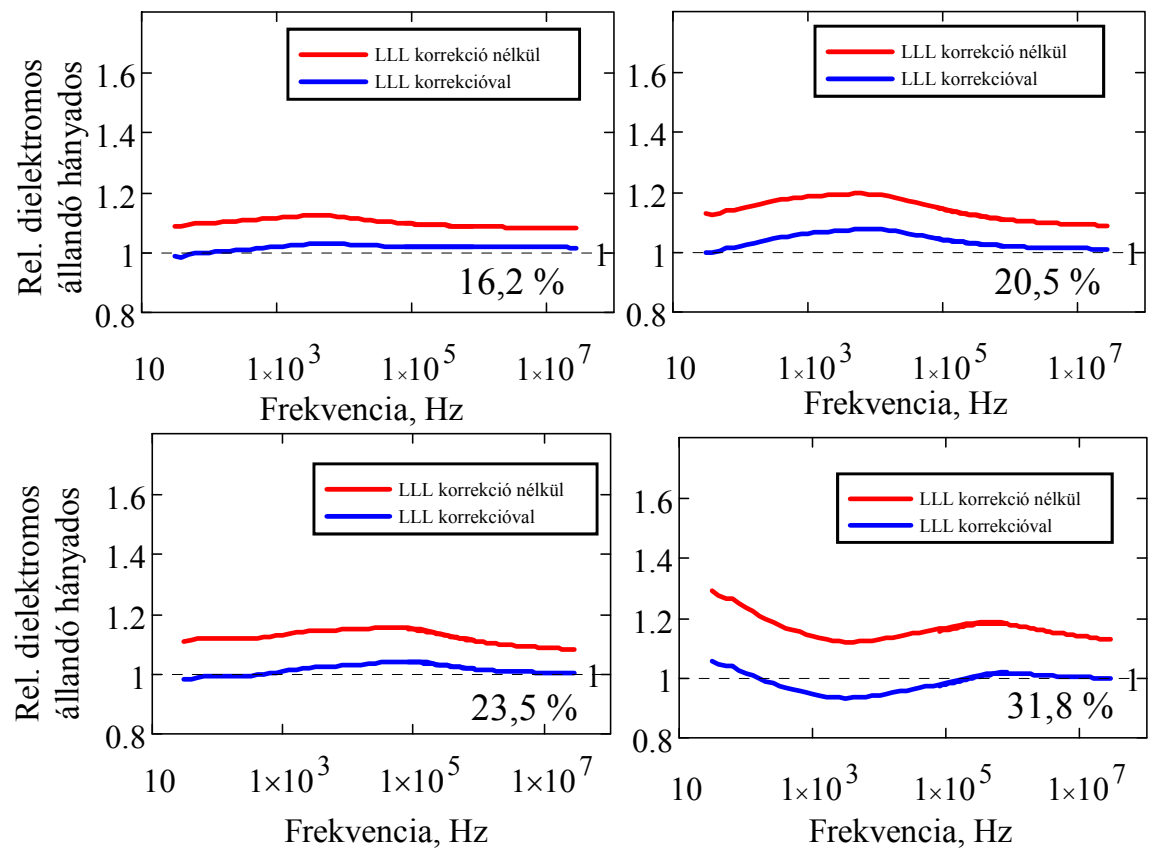

42. ábra A 16,2 \%-31,8 \% nedvességtartalmú kukorica minták relatív dielektromos állandó hányadosai ( $\varepsilon^{\prime}{ }_{\text {lassú }} / \varepsilon_{\text {gyors }}$ ) a frekvencia függvényében, LLL sürüségkorrekció előtt és után, a módosított hengerkondenzátor tesztcellával mérve

A feltevésem igaznak bizonyult. A központi elektród meghosszabbításával a relatív dielektromos állandó hányados értékében a sürüségkorrekció alkalmazásával jelentős javulást tudtam elérni. A tesztcella módosításával az egyes betöltésekhez tartozó relatív dielektromos állandó értékeire alkalmazva az LLL sürüségkorrekciót a relatív dielektromos állandó hányados értéke maximum $\pm 0,05$ eltéréssel megközelítette 1-et minden nedvességtartalomnál és frekvencián.

\subsubsection{Az LLL sürüségkorrekció és a nyomás vizsgálata}

A módosított hengerkondenzátorban elhelyezkedő kukorica minta tetején $\mathrm{P} 1=1,9 \mathrm{kPa}$ és $\mathrm{P} 2=3,9 \mathrm{kPa}$ nyomásokat alkalmaztam. A relatív dielektromos állandó hányadosok az LLL sürüségkorrekció előtt és után a 43. ábrán láthatók: 

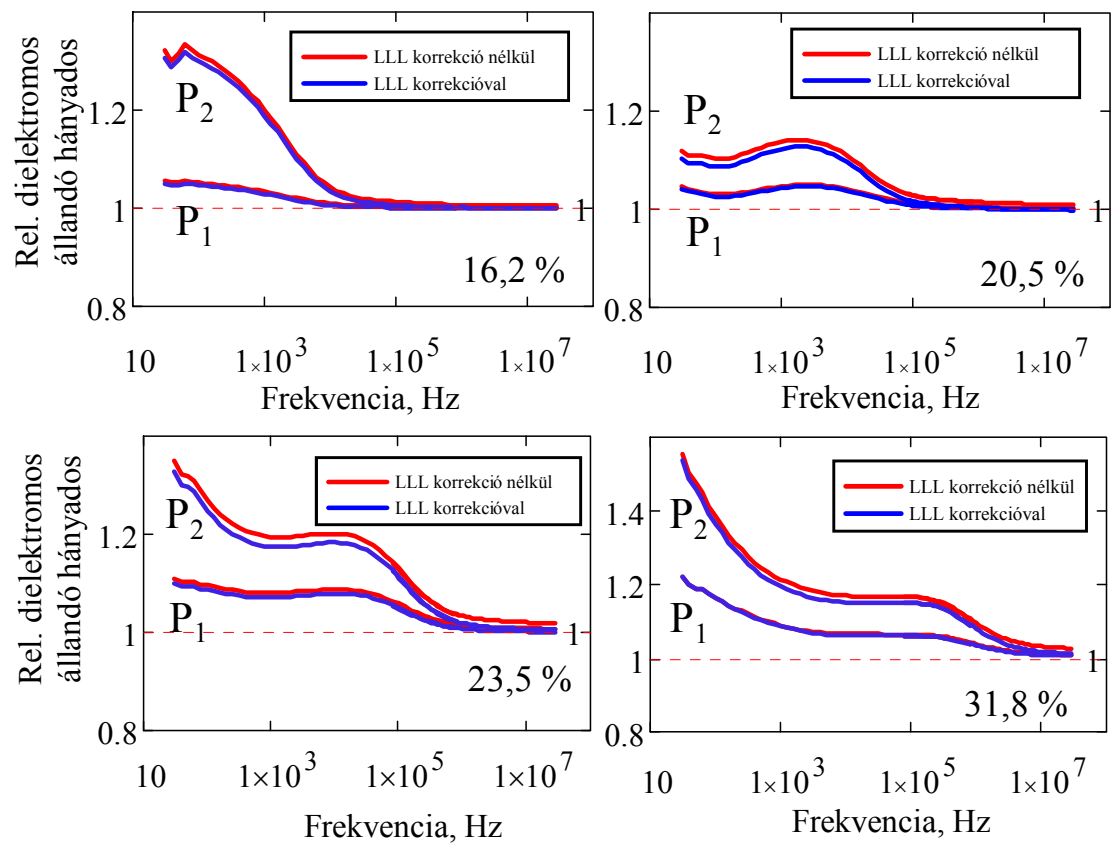

43. ábra A 16,2 \% és 31,8 \% nedvességü kukorica minták relatív dielektromos állandó hányadosai,

$\varepsilon_{(\mathrm{P} 1)} / \varepsilon^{\prime}{ }_{\text {gyors }}$ és $\varepsilon^{\prime}{ }_{(\mathrm{P} 2)} / \varepsilon^{\prime}$ gyors, a frekvencia függvényében, LLL sürüségkorrekció elött és után, a módosított hengerkondenzátor tesztcellával mérve. $\mathrm{P} 1=1,9 \mathrm{kPa}$ és $\mathrm{P} 2=3,9 \mathrm{kPa}$

A 43. ábrán tesztcella módosítása után az LLL sürüségkorrekció alkalmazásával a relatív dielektromos állandó hányados csak kis mértékben változik a teljes frekvenciatartományban. A változás nagyobb a $3,9 \mathrm{kPa}$ nyomás esetén. Az LLL sürüségkorrekció eredményességét megvizsgálva megállapíthatjuk, hogy a nyomás hatására a mintában létrejött sürüség különbségeket nem tudta eliminálni.

Összehasonlítva a GAC, UGMA, hengerkondenzátor és módosított hengerkondenzátor tesztcellákkal végzett méréseket az alábbi következtetéseket vontam le:

1. A Landau-Lifshitz, Looyenga sürüségkorrekció a különböző betöltések hatására létrejött sürüségkülönbségek hatását, a számított nedvességtartalomban ezáltal létrejövő hibát 11,2 \% 31,8 \% nedvességtartalmú kukorica mintákon eredményesen korrigálta a GAC, az UGMA és a módosított hengerkondenzátor tesztcellákkal történt mérések során $100 \mathrm{~Hz}$ és $10 \mathrm{MHz}$ között.

2. A Landau-Lifshitz, Looyenga sürüségkorrekció a betöltések hatására létrejött sürüségkülönbségek hatását eredményesen korrigálta 10,6 \% - 16,7 \% nedvességtartalmú szója mintákon 100 kHz és $10 \mathrm{MHz}$ között az UGMA tesztcellával történt mérések során.

3. A Landau-Lifshitz, Looyenga sürüségkorrekció hatékonyan müködik a rázás által okozott sürüségkülönbségek korrigálására, de nem eredményes a nyomás hatását kiküszöbölni 11,2 \% - 
31,8 \% nedvességtartalmú kukorica mintákon és 10,6 \% - 16,7\% nedvességtartalmú szója mintákon a GAC, az UGMA és a módosított hengerkondenzátor tesztcellákkal történt mérések során $100 \mathrm{~Hz}$ és $10 \mathrm{MHz}$ között.

4. A négy különböző tesztcellával 11,2\% - 31,8 \% nedvességtartalmú kukorica mintákon és 10,6 \% - 16,7 \% nedvességtartalmú szója mintákon történt mérések során megállapítottam, hogy a nyomás hatása a relatív dielektromos állandó görbékre különbözik a rázás hatásától $100 \mathrm{kHz}$ és $10 \mathrm{MHz}$ frekvenciatartományban.

5. A hengerkondenzátor tesztcellával végzett méréseink alapján megállapítottam, hogy ha a tesztcella középső elektródja rövidebb, mint a külső elektródja, akkor a középső elektród mellett és felett kialakuló különböző mintasürüség miatt a Landau-Lifshitz, Looyenga sürüségkorrekció eredményessége jelentősen romlik. A probléma megoldható a középső elektród meghosszabbításával. A gabona nedvességmérésében a sürüségkülönbségek okozta hibák kiküszöböléséhez elengedhetetlen és alapvető a minta pontos sürüségének ismerete a tesztcella elektromosan aktív részében.

\subsection{DIELEKTROMOS SPEKTRUMOK NYOMÁSFÜGGÉSE}

Az előző fejezetben megmutattam, hogy a nyomásnak más a hatása a dielektromos görbékre, mint a különböző betöltési módoknak. Az eltérés abban is megmutatkozott, hogy a mintán akár a legkisebb nyomást is alkalmazva az LLL sürüségkorrekció a relatív dielektromos állandó hányados értékeire nem hatott. Ebben a fejezetben a relatív dielektromos állandó és a veszteségi tényező változását mutatom be 1,4 kPa-19,6 kPa közötti nyomások hatására a frekvencia függvényében. Az eredményeket az egyes tesztcellákra külön közlöm.

\subsubsection{GAC tesztcella}

A 44. ábrán a 0 - 14,29 kPa nyomások hatása a relatív dielektromos állandóra és a veszteségi tényezőre követhető nyomon 13,5 \% - 23,5 \% nedvességtartalmú kukorica mintákon, ahol $0 \mathrm{kPa}$ a gyors betöltésnek felel meg. 

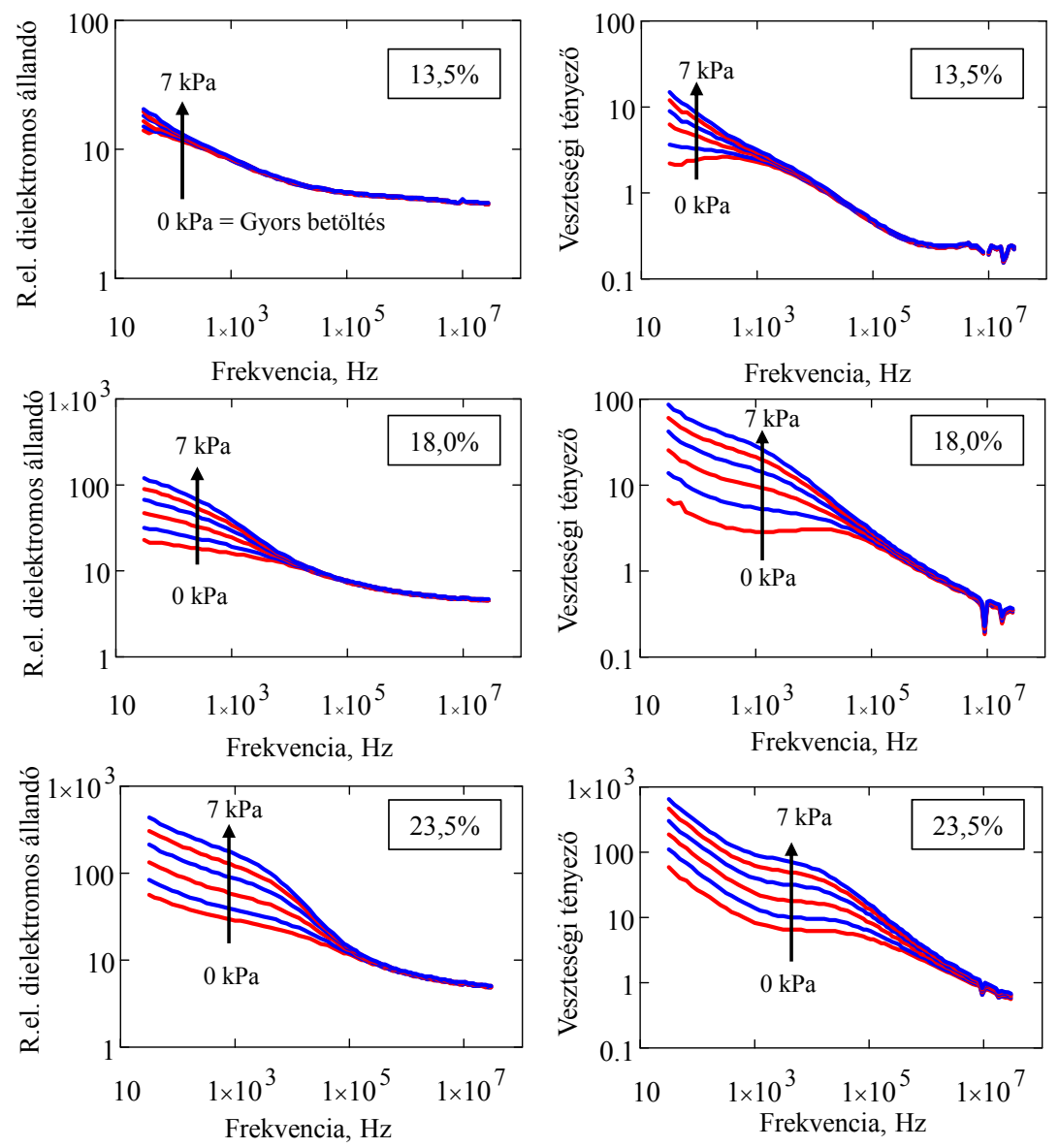

44. ábra Egy 13,5 \%, 18,0 \% és egy 23,5 \% nedvességtartalmú kukorica minta relatív dielektromos állandójának és veszteségi tényezőjének változása a nyomás hatására a frekvencia függvényében GAC tesztcellával mérve. Az alkalmazott nyomások 1,4 kPa; 2,8 kPa; 4,2 kPa; $7 \mathrm{kPa}$. A $0 \mathrm{kPa}=$ gyors betöltés.

A 44. ábrán látható kukorica minták relatív dielektromos állandó és veszteségi görbéi a növekvő nyomás hatására és a nedvességtartalom növekedésével egyre jobban szétválnak $100 \mathrm{kHz}$ alatt. A relatív dielektromos állandó érteke már 1,4 kPa nyomás hatására is körülbelül tízzel lesz nagyobb, mint a minta terheletlen állapotában mért relatív dielektromos állandó $18 \%$ nedvességü kukorica mintánál. A nyomás hatása kisebb a $100 \mathrm{kHz}$ feletti frekvenciatartományban. A relatív dielektromos állandó görbéken meghatározható egy olyan frekvenciatartomány, melyben a nyomásnak elhanyagolható a hatása. E tartomány a 13,5\% nedvességü mintán körülbelül $1 \mathrm{kHz}$ felett, a $18 \%$-os mintánál $10 \mathrm{kHz}$ felett és a 23,5\% nedvességtartalmú kukorica esetén $100 \mathrm{kHz}$ felett található. Mindhárom nedvességtartalomnál a $0 \mathrm{kPa}$ nyomáshoz tartozó veszteségi görbéken megfigyelhető két vezetési hatás: az elektród polarizáció és a Maxwell-Wagner relaxáció. A Maxwell-Wagner relaxációt a veszteségi csúcs, a veszteségi tényező maximuma jelzi a karakterisztikus frekvencián. Az elektród polarizáció könnyen felismerhető, mert ilyenkor a relatív 
dielektromos állandó és a veszteségi tényező görbék képe egy egyenes a frekvencia függvényében log-log diagramon ábrázolva, és a veszteségi tényező nagyobb, mint a relatív dielektromos állandó. A nyomás növekedésével az elektród polarizáció egyre jobban dominálja a dielektromos görbéket minden nedvességtartalmon. A Maxwell-Wagner relaxációt jellemző veszteségi csúcs eltolódik a nagyobb frekvencia értékek felé. Nehézséget okoz azonban annak az elektród polarizáció és a Maxwell-Wagner relaxációs frekvenciatartományainak pontos meghatározása.

\subsubsection{Hengerkondenzátor tesztcella}

A 45. ábrán a 0-15,2 $\mathrm{kPa}$ nyomások hatása látható a relatív dielektromos állandóra és a veszteségi tényezőre 13,5 \% - 23,5 \% nedvességtartalmú kukorica mintán.
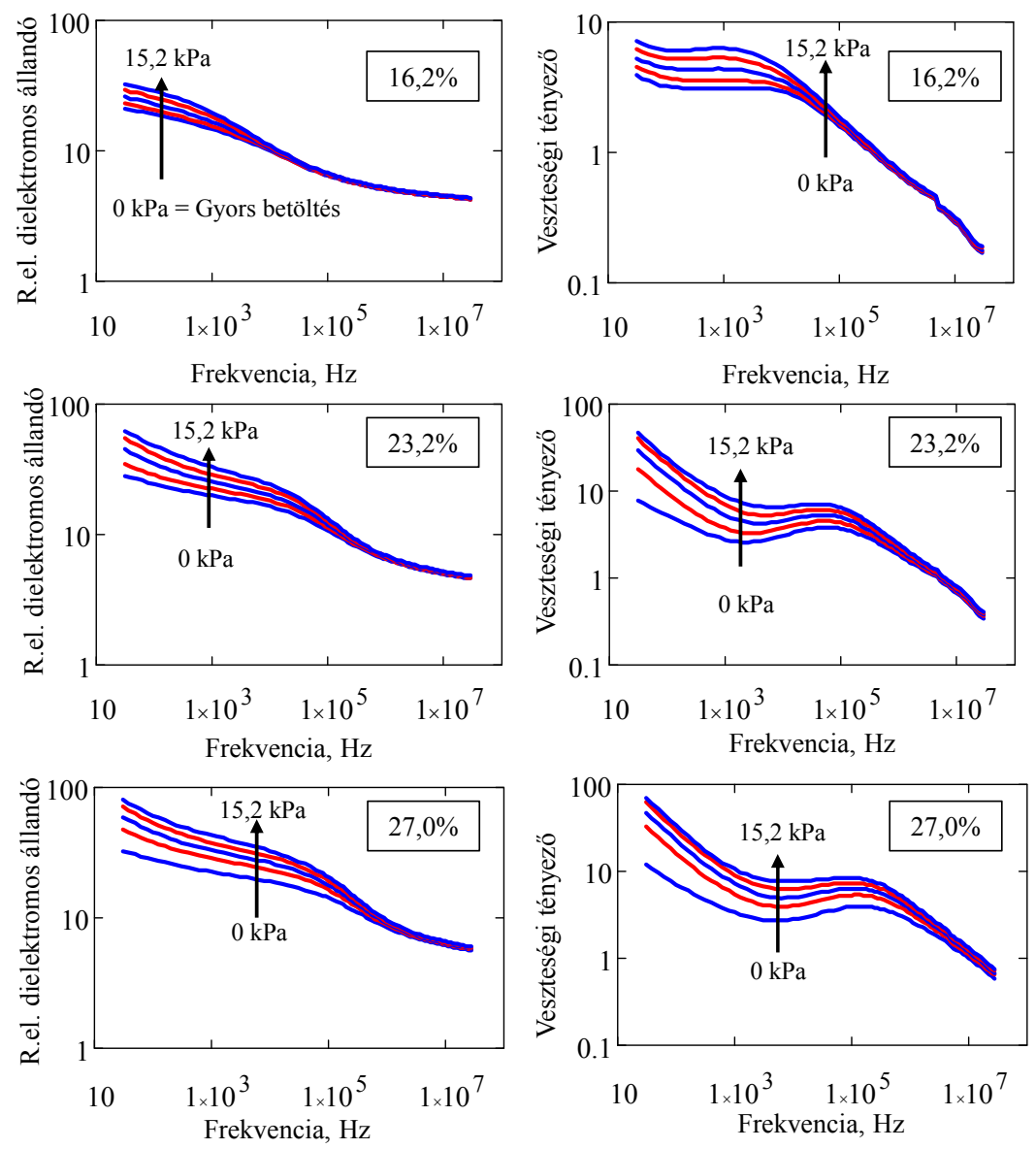

45. ábra Egy 16,2 \%, 23,2 \% és egy 27,0 \% nedvességtartalmú kukorica minta relatív dielektromos állandójának és veszteségi tényezőjének változása a nyomás hatására a frekvencia függvényében hengerkondenzátor tesztcellával mérve. Az alkalmazott nyomások: 1,5 kPa; 7,6 kPa; $11,4 \mathrm{kPa}$; $15,2 \mathrm{kPa}$. A $0 \mathrm{kPa}$ a minta gyors betöltését jelenti.

A 45. ábrán látható relatív dielektromos állandó és veszteségi tényező görbéken a nyomás hatása ugyanúgy jelenik meg, mint ahogy azt a GAC tesztcellánál láttuk. A görbék lefutása 
alapvetően nem változik a nyomás hatására, azonban az $1 \mathrm{kHz}$ alatti frekvenciákon az elektród polarizáció egyre inkább dominánssá válik a nyomás nagyságának növekedésével. A relatív dielektromos állandó görbéken meghatározható egy olyan frekvenciatartomány, melyben a növekvő nyomásnak nincs jelentős hatása a relatív dielektromos állandóra. Ez a frekvenciatartomány a 16,2 \% nedvességű kukorica mintán körülbelül $100 \mathrm{kHz}$ felett, a 23,2 \%-os mintánál $1 \mathrm{MHz}$ felett és a $27,0 \%$ minta esetében $10 \mathrm{MHz}$ felett található. A veszteségi tényező görbéken ezekben a frekvenciatartományokban a nyomás hatása kis mértékben ugyan, de különbséget okoz. A nyomás hatása a $100 \mathrm{kHz}$ alatt nagyobb, mint e frekvencia felett.

\subsubsection{Módosított hengerkondenzátor tesztcella}

A 46. ábrán 0 - 19,4 kPa nyomások hatása látható a relatív dielektromos állandóra és a veszteségi tényezőre 14,3 \% - 20,0 \% nedvességtartalmú kukorica mintán.
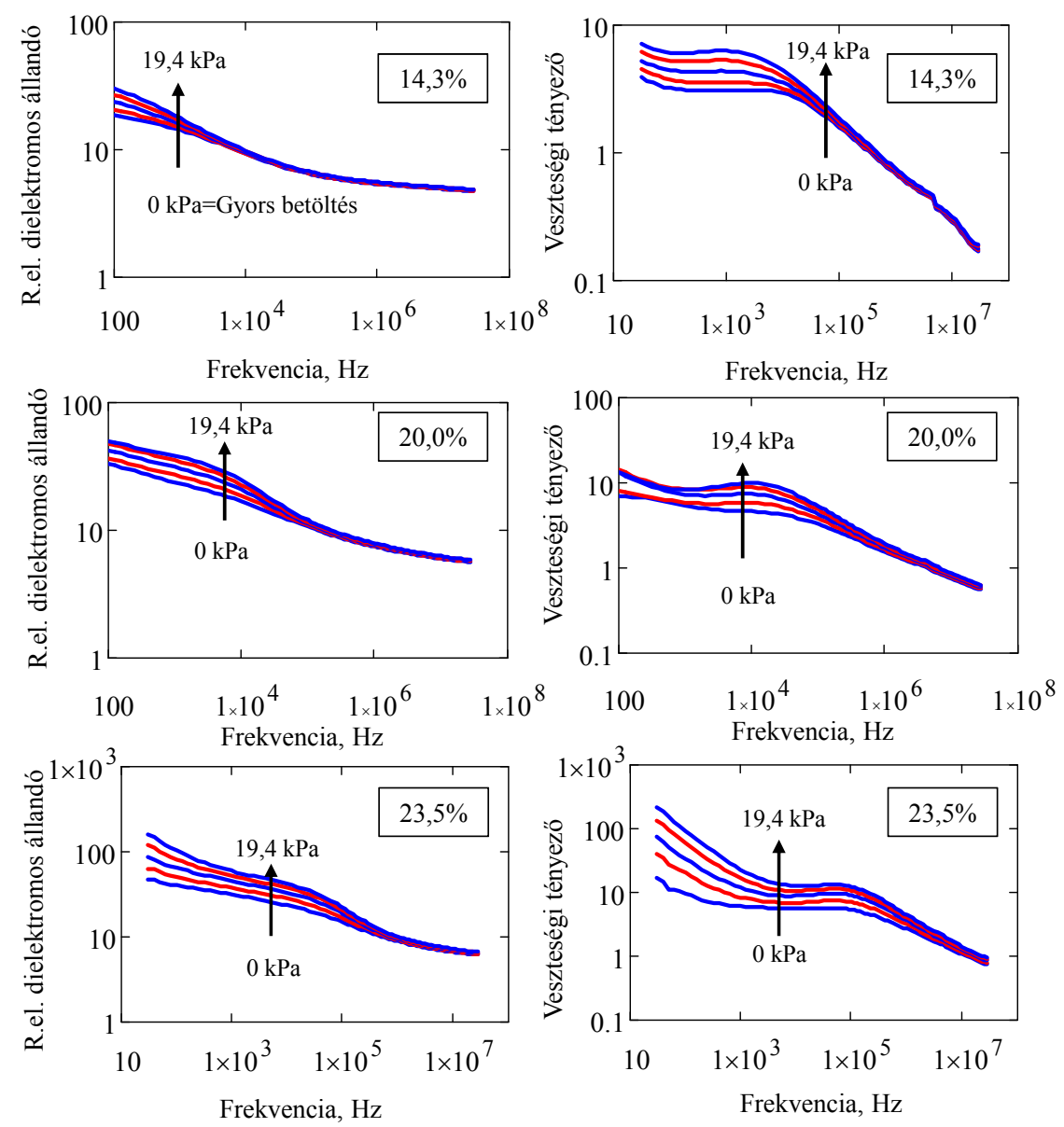

46. ábra Egy 14,3 \%, 20,0 \% és egy 23,5 \% nedvességtartalmú kukorica minta relatív dielektromos állandójának és veszteségi tényezőjének változása a nyomás hatására a frekvencia függvényében módosított hengerkondenzátor tesztcellával mérve. Az alkalmazott nyomások: 1,9 kPa; 3,9 kPa;

9,7 kPa; 19,4 kPa. A $0 \mathrm{kPa}$ a minta a gyors betöltését jelenti. 
A 46. ábrán látható minták relatív dielektromos állandó és veszteségi tényező görbéi is hasonlóan a GAC és hengerkondenzátor tesztcellánál tapasztaltakhoz a nyomás hatására elválnak egymástól. A relatív dielektromos állandó görbéken a nyomás hatása elhanyagolható a 14,3\% nedvességü kukorica mintán körülbelül $100 \mathrm{kHz}$ felett, a 20,0\%-os mintánál $1 \mathrm{MHz}$ felett és a $23,5 \%$ minta esetében $10 \mathrm{MHz}$ felett található. Az elektródpolarizációs egyenes a nyomás növekedésével egyre dominánssá válik a $10 \mathrm{kHz}$ alatti frekvenciatartományban. Veszteségi csúcs a nagyobb frekvenciák felé tolódik el.

\subsubsection{UGMA tesztcella}

Az UGMA tesztcellával végzett terheléses kísérletek során a dielektromos méréseket a nyomás megszüntetése után végeztem el, ellentétben a GAC, hengerkondenzátor és a módosított hengerkondenzátorral történt mérésekkel, melyek során a dielektromos spektrumok felvétele nyomás alatt történt. A nyomás ilyen módon történt alkalmazásával lehetőségem nyílt megvizsgálni, hogy a terhelés megszünése után kimutatható-e a nyomás hatása a dielektromos görbéken a $10 \mathrm{MHz}$ alatti frekvenciatartományban. A vizsgálatokhoz kis nyomásértékeket 1,77 kPa, 3,55 kPa alkalmaztam a legkisebb, a dielektromos görbéken már szignifikáns különbséget okozó nyomás meghatározásához. A statisztikai elemzéseket a relatív dielektromos állandó értékeire végeztem el, mert ez a jellemző határozza meg a számított nedvességtartalom értékét. A 47. ábrán a nyomás hatása látható a relatív dielektromos állandóra és a veszteségi tényezőre $14,3 \%-20,0 \%$ nedvességtartalmú kukorica mintán. 

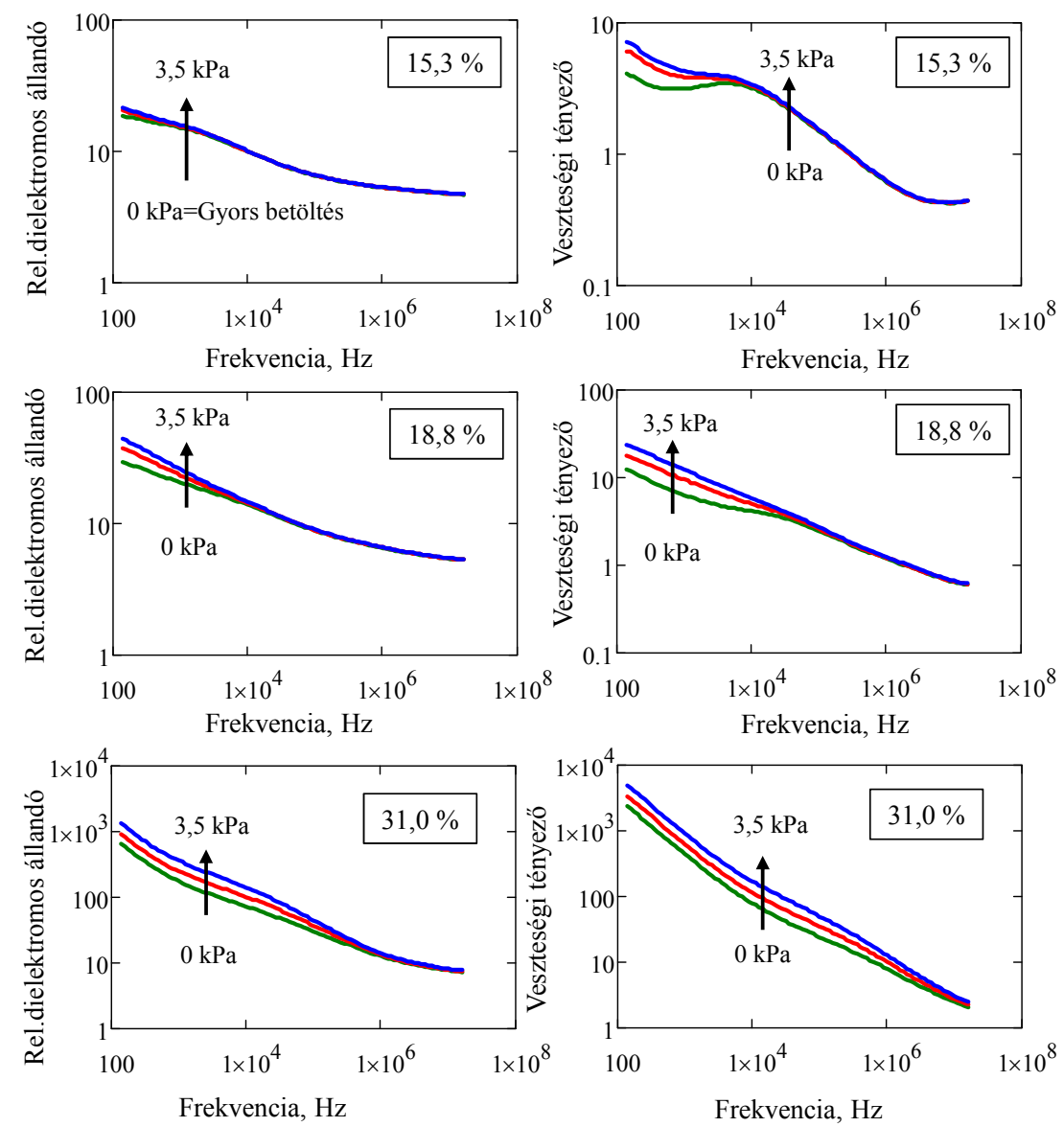

47. ábra Egy 15,3 \%, 18,8 \% és egy 31,0 \% nedvességtartalmú kukorica minta relatív dielektromos állandójának és veszteségi tényezőjének változása a nyomás hatására a frekvencia függvényében UGMA tesztcellával mérve. A görbék minden nyomásértéken 3 ismétlés átlagából származnak. Az alkalmazott nyomások: $1,8 \mathrm{kPa} ; 3,5 \mathrm{kPa}$. A $0 \mathrm{kPa}$ minta a gyors betöltését jelenti.

A 47. ábrán látottakból megállapítható, hogy bár a dielektromos méréseket a nyomás megszünése után vettem fel, a relatív dielektromos állandó és veszteségi tényező a nyomás hatására megváltozik. A változás nagysága függ a minta nedvességtartalmától és a frekvenciától. Minél szárazabb volt a minta, annál kisebb frekvenciákon jelentkezik a nyomás hatása. A 15,3\%-os nedvességű mintán az általunk alkalmazott nyomásoknak nincs hatása $10 \mathrm{kHz}$ felett. A $10 \mathrm{kHz}$ alatti frekvenciákon a legnagyobb változás a veszteségi tényező görbén tapasztalható: a nyomás növekedésével a veszteségi tényező és relatív dielektromos állandó megnő, de ez utóbbi csak kis mértékben változik. A nedvességtartalom növekedésével, a nyomás hatása egyre nagyobb frekvenciákon jelenik meg. 
A kukorica és a szója relatív dielektromos állandó átlagaiban $30 \mathrm{~N}$ terhelőerő hatására (ami 5,3 kPa nyomásnak felel meg) szignifikáns különbséget tapasztaltam ( 48. ábra)

Kukorica

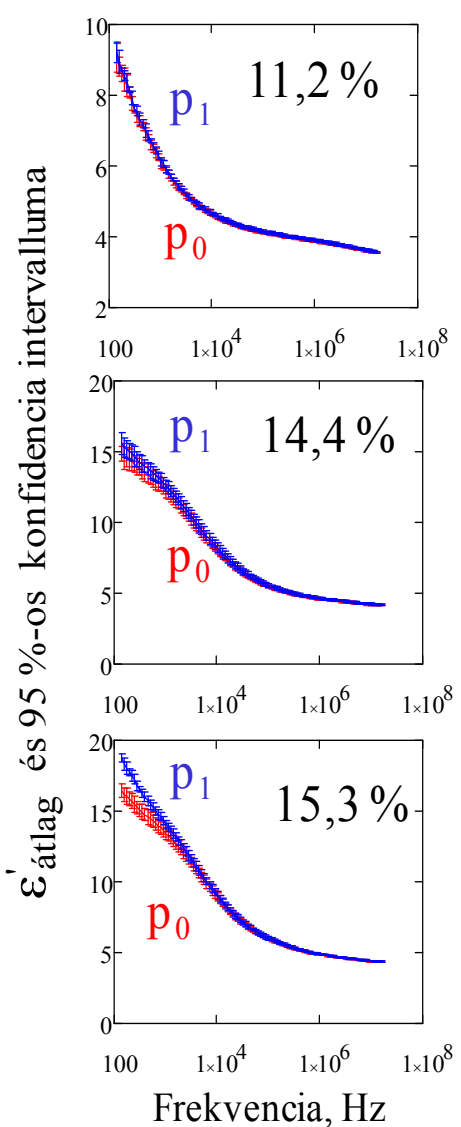

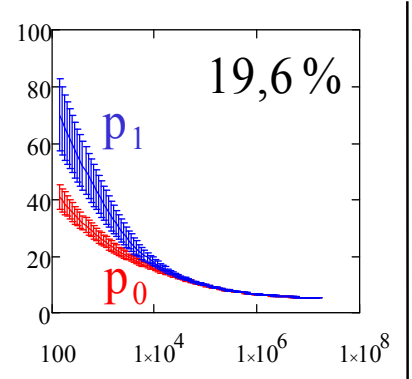
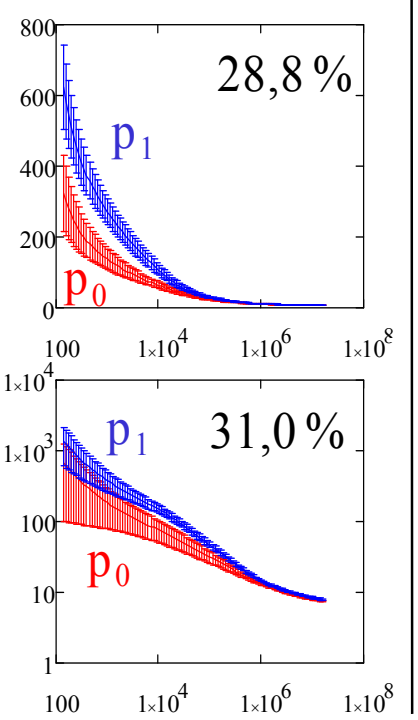

Frekvencia, $\mathrm{Hz}$

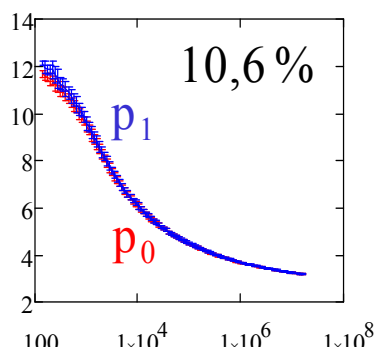

Szója

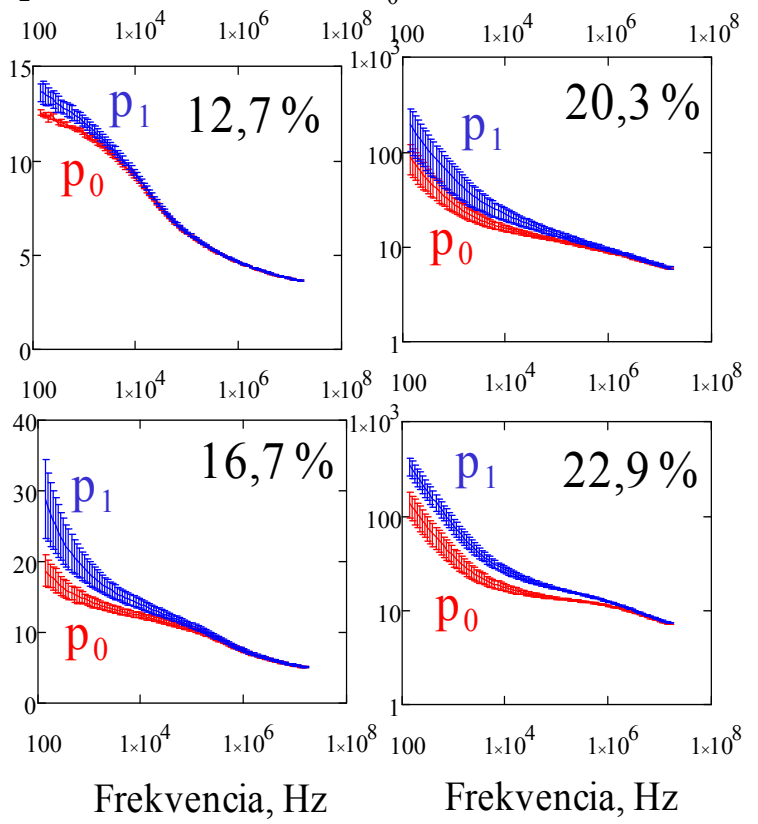

48. ábra Kukorica és szója relatív dielektromos állandó (három ismétlésből származó) átlaga és $95 \%$-os konfidencia intervalluma a frekvencia függvényében. Piros színnel a terheletlen állapotot és kék színnel az alkalmazott nyomást jelölt jelöltem, ahol P1 $=5,3 \mathrm{kPa}$

A dielektromos méréseket a terhelés megszünte után elvégezve, kimutatható szignifikáns a hatás a relatív dielektromos állandó értékekben. Kukorica esetén 15,3\%, szója minták esetén 12,7 \% nedvességtartalom felett jelentkezik szignifikáns különbség. A száraz mintáknál $1 \mathrm{kHz}$ alatt, a nedveseknél (31\%-os kukorica és 22,9\% szója minták esetén) $1 \mathrm{MHz}$ alatti frekvencia tartományban mutatható ki szignifikáns eltérés.

A számított nedvességtartalom értékében a $\mathrm{P}_{1}=1,78 \mathrm{kPa}$ és $\mathrm{P}_{3}=5,33 \mathrm{kPa}$ nyomás hatására közvetetten megjelenő különbséget a 49. ábrán ábrázoltam a frekvencia függvényében. 


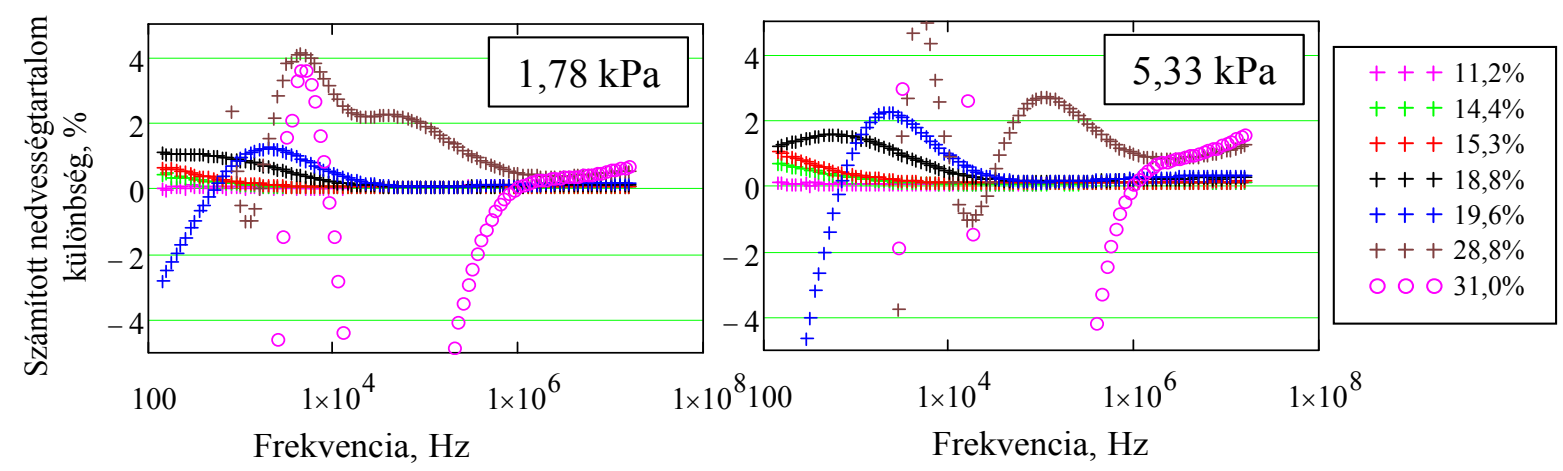

49. ábra Három ismétlésből származó átlag számított nedvességtartalom különbség a frekvencia függvényében. A különbség az adott nyomáshoz tartozó számított nedvességtartalom és a terheletlen állapothoz tartozó számított nedvességtartalom különbsége.

A 49. ábrán látható minták nedvességtartalmának kiszámításánál minden esetben alkalmaztunk hőmérséklet és LLL sürüségkorrekciót és csak ezután vettük a terhelt és terheletlen állapotok különbségeit. Megállapítható, hogy a 18,8 \% nedvesség alatti kukoricák számított nedvességtartalom különbsége a nyomás hatására $10 \mathrm{kHz}$ felett közel nulla, $10 \mathrm{kHz}$ alatt maximum $1 \%$ nedvességszázalék az eltérés a terhelt és terheletlen minták számított nedvességtartalom értéke között. Az különbség mindig pozitív volt, azaz a terhelt minta nedvességtartalmát a ténylegesnél nagyobbra becsültük. A 18,8 \%-nál nedvesebb kukoricák számított nedvességtartalom különbsége a frekvencia függvényében hol pozitív, hol negatív irányban tér el. Ez az eltérés meghaladhatja akár a \pm 4 nedvességszázalékot is.

Összefoglalva az 1,41 kPa-19,6 kPa közötti nyomások relatív dielektromos állandó és veszteségi tényezö görbéire gyakorolt hatását megállapíthatjuk a következőket:

1. Az 1,41 kPa vagy annál nagyobb nyomásoknak a 11,2 \%-31\% nedvességtartalmú kukorica minták dielektromos görbéin kimutatható hatása van a $100 \mathrm{~Hz}-10 \mathrm{MHz}$ frekvenciatartományban.

2. A nyomás hatása akkor is jelentkezik a dielektromos görbéken, ha a dielektromos spektrumok mérése közvetlenül a nyomás megszünése után történik.

3. A nyomásnak kimutatható hatása van a 11,2\%-31\% nedvességtartalmú kukorica minták dielektromos görbéire a GAC, az UGMA, a hengerkondenzátor és a módosított hengerkondenzátor tesztcellákkal végzett mérések során.

4. A nyomás hatására az egyes vezetési hatások, úgy mint az elektród polarizáció és a MaxwellWagner relaxáció jellemző frekvenciatartományai eltolódnak. 
5. A nyomás és a minta nedvességtartalmának növekedésével az elektród polarizáció egyre jobban dominál a dielektromos görbéken.

\subsection{A TERHELÉS HATÁSA AZ ARGAND ÁBRÁKON}

A relatív dielektromos állandót és veszteségi tényezőt a frekvencia függvényében ábrázolva egyértelmüen látható a nyomás hatása minden tesztcellánál, azonban a vezetési hatások, melyek az alacsony frekvenciás mérések során nehézségeket okoznak, nem választhatók szét. Az adatok elemzése alapján megállapítottam, hogy a dielektromos jellemzők Argand ábrán való megjelenítésével a vezetési hatások láthatóvá és elkülöníthetővé válnak. Vajon a nyomás dielektromos jellemzőkre gyakorolt hatása is jellemezhető Argand paraméterekkel?

Az 50. ábra bal oldalán a nyomás hatása látható egy $18 \%$-os kukorica minta relatív dielektromos állandó és veszteségi tényezőjére a frekvencia függvényében, míg a jobb oldalon ugyanazon minta, azonos nyomásokon Argand ábrán való megjelenítése látható.
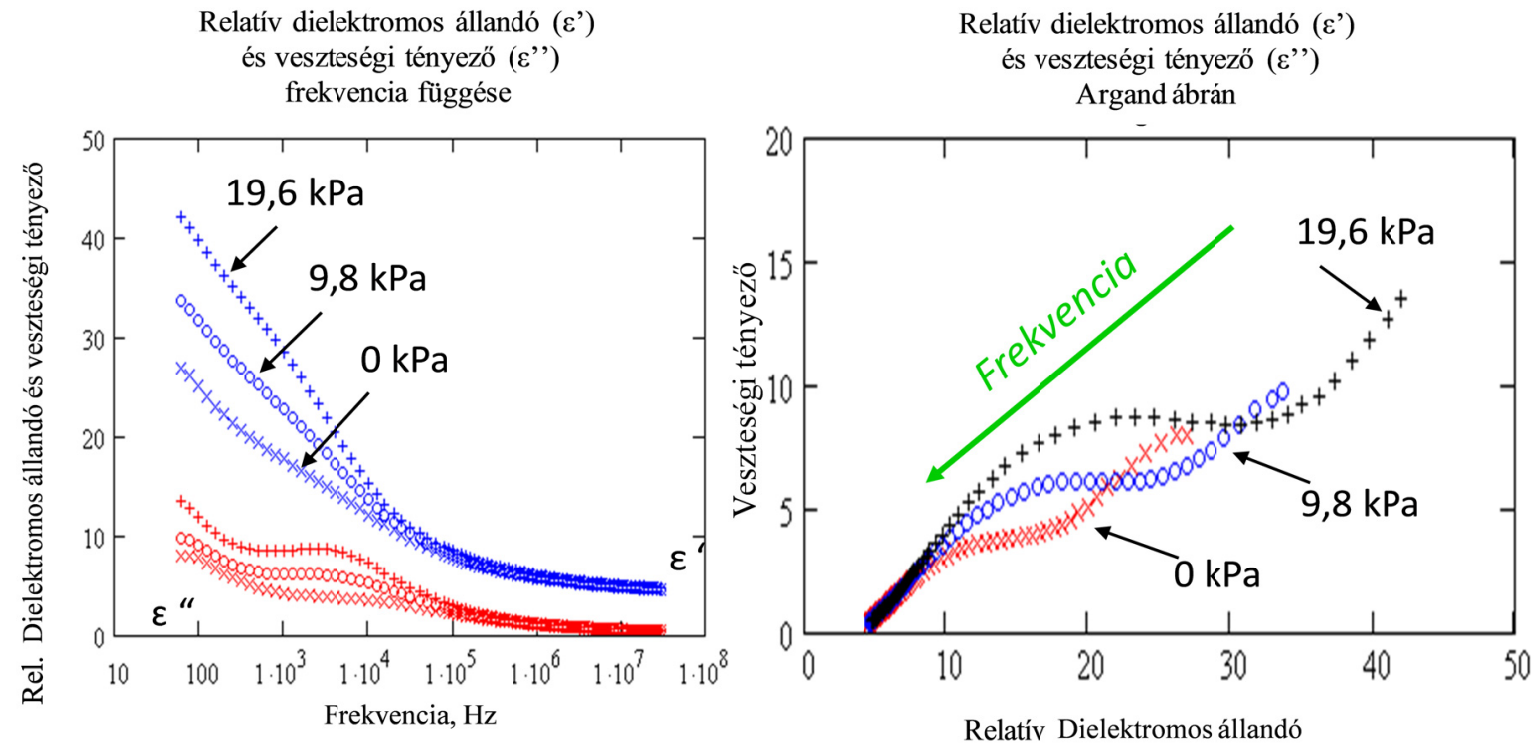

50. ábra Egy 18 \%-os kukorica minta relatív dielektromos állandója és veszteségi tényezője a frekvencia függvényében és Argand ábrán, módosított hengerkondenzátor tesztcellával

Az Argand ábrán való ábrázolással a Maxwell-Wagner relaxációra jellemző körív és az elektród polarizációt jelző egyenes jól elkülöníthető, és a görbék alakja jellemző maradt. Az alkalmazott nyomás ellenére a görbék leírhatók egy kör és/vagy egy egyenes kombinációjával.

Az 51. ábrán különböző nedvességtartalmú minták Argand görbéit hasonlítottam össze három tesztcellánál abban az esetben, amikor a dielektromos méréseket nyomás alatt végeztem. 

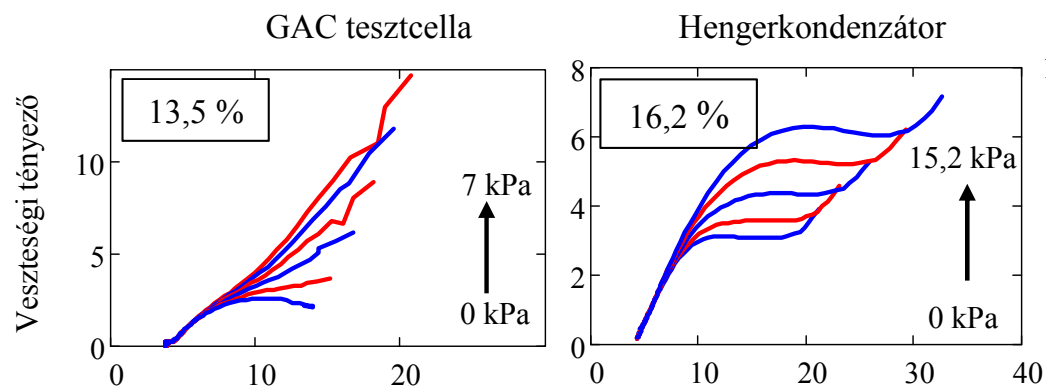

Módosított hengerkondenzátor
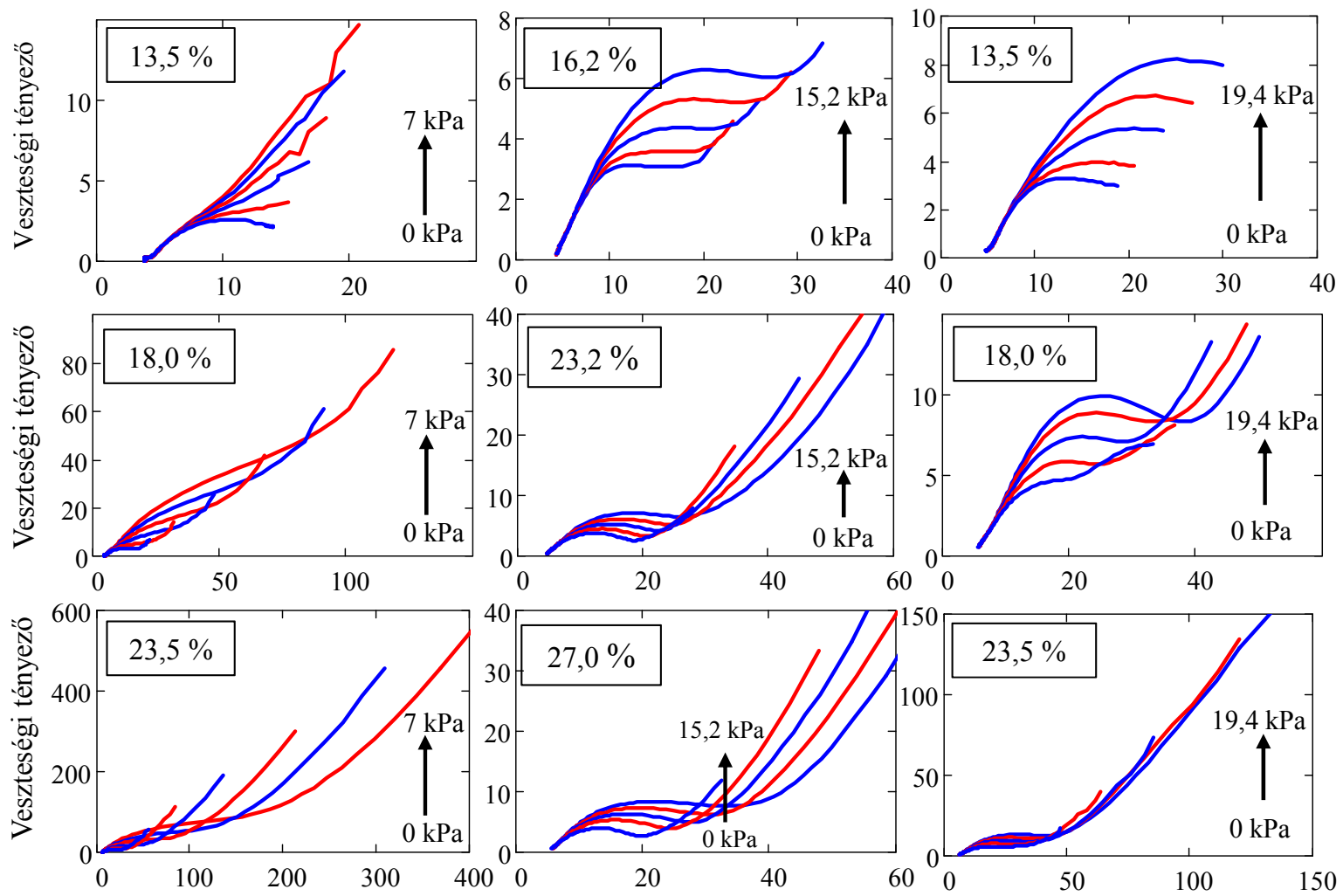

Rel. dielektromos állandó

Rel. dielektromos állandó

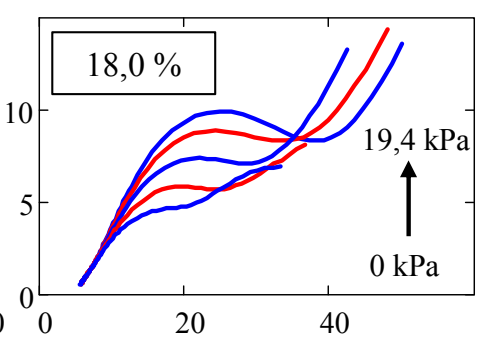

51. ábra Különböző nedvességtartalmú kukorica minták Argand ábrái. A GAC, a

hengerkondenzátor és a módosított hengerkondenzátor tesztcellákkal végzett dielektromos mérések nyomás alatt történtek.

Az ábrából megállapítható, hogy az Argand görbék minden nedvességtartalmon és mindhárom tesztcellánál meghatározott módon változtak, azaz a nyomás hatására a jelleggörbék alakja nem, de a Maxwell-Wagner relaxáció köríve és az elektród polarizáció egyenese többszörösére nőtt. Mindkét hengerkondenzátornál megfigyelhető, hogy a száraz mintáknál a Maxwell-Wagner relaxáció erősödik a nyomás hatására, a majd a minta nedvességtartalmának növekedésével a Maxwell-Wagner körív növekedése mellett egyre inkább az erősödő elektródpolarizáció lesz domináns a görbéken. A GAC tesztcellánál a nyomás hatása hasonló, de amiatt, hogy a tesztcella elektródjai szigeteletlenek az elektród polarizáció drasztikusabban jelentkezik már a száraz mintánál is. Ugyanezt tapasztaltam a 3. mellékletben található kukoricáknál is. A kör és egyenes illesztéseket az 52. ábrán mutatom be egy 14,3 \% és egy 20,1\% nedvességü kukorica mintán. 
Módosított hengerkondenzátor
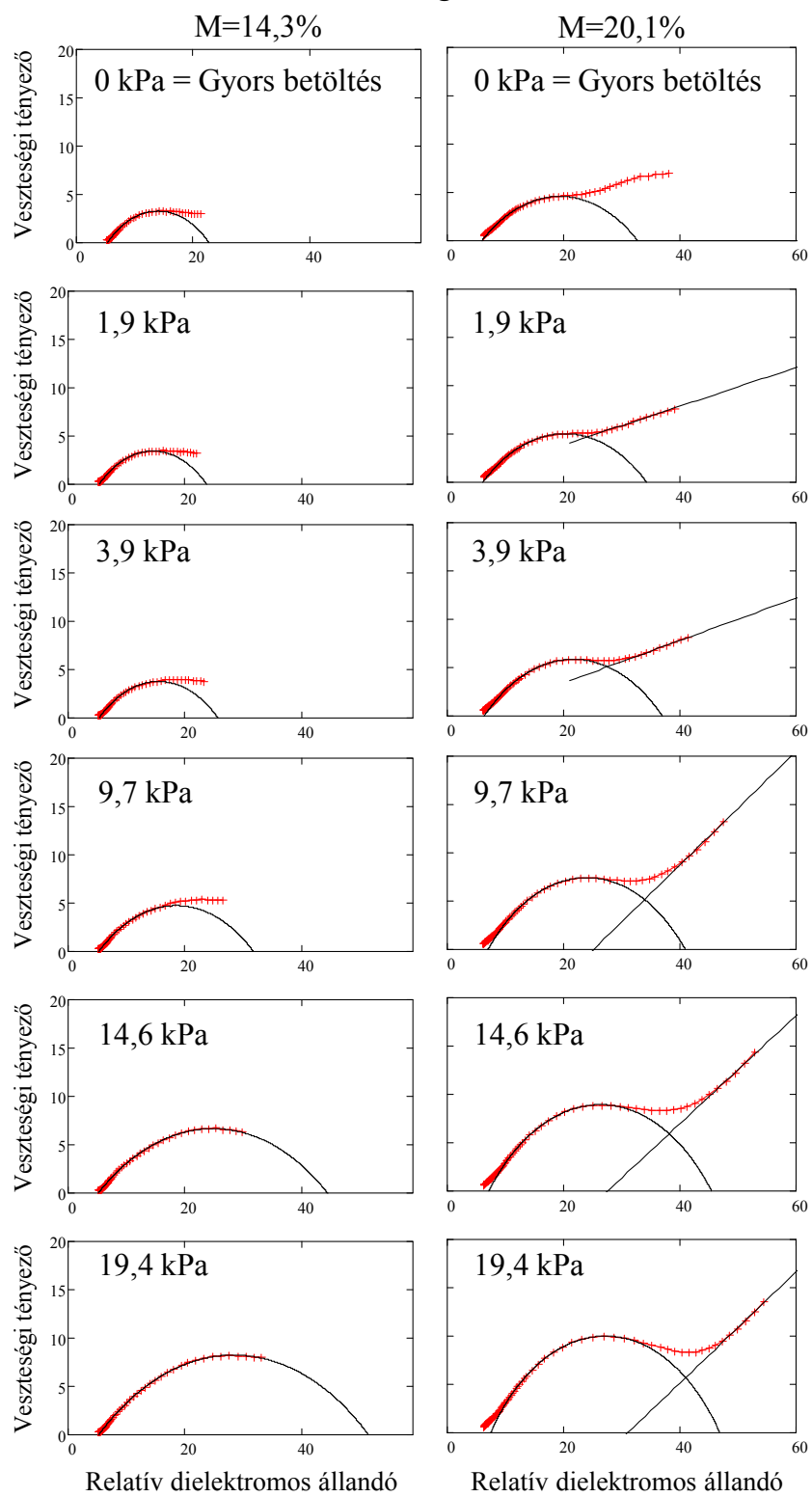

52. ábra A terhelés hatása száraz és nedves kukoricaminta Argand görbéire

Az illesztéshez használt Mathcad14 programmal írt algoritmus (Gillay 2003) az illesztett körívből és egyenesből automatikusan meghatározza az illesztett paramétereket. A MaxwellWagner relaxációt jellemző körív paraméterei közül a húrhossz és a karakterisztikus frekvencia korrelál a nyomással. (53. ábra). 


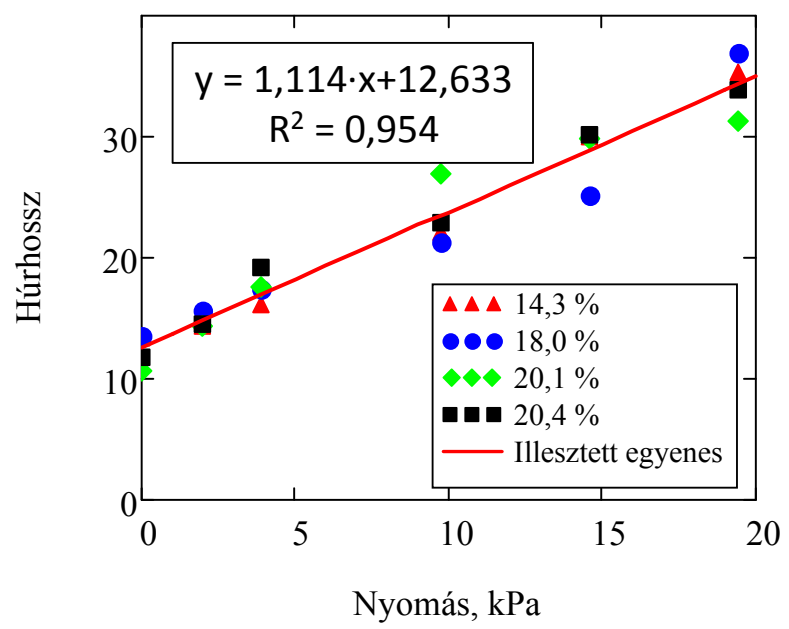

53. ábra A húrhossz nyomás függése, módosított hengerkondenzátor tesztcella.

Az ábra alapján megállapítható, hogy 14,3\% - 20,4 \% nedvességtartalmú kukoricák esetén a Maxwell-Wagner relaxációt jellemző húrhossz független a minta nedvességtartalmától, és a nyomás növekedésével szigorúan monotonon nő. A húrhossz és a nyomás kapcsolatának szorosságát jelző lineáris determinációs együttható, $\mathrm{R}$ értéke 0,954 .

A karakterisztikus frekvencia a nyomás függvényében látható az 54. ábrán.

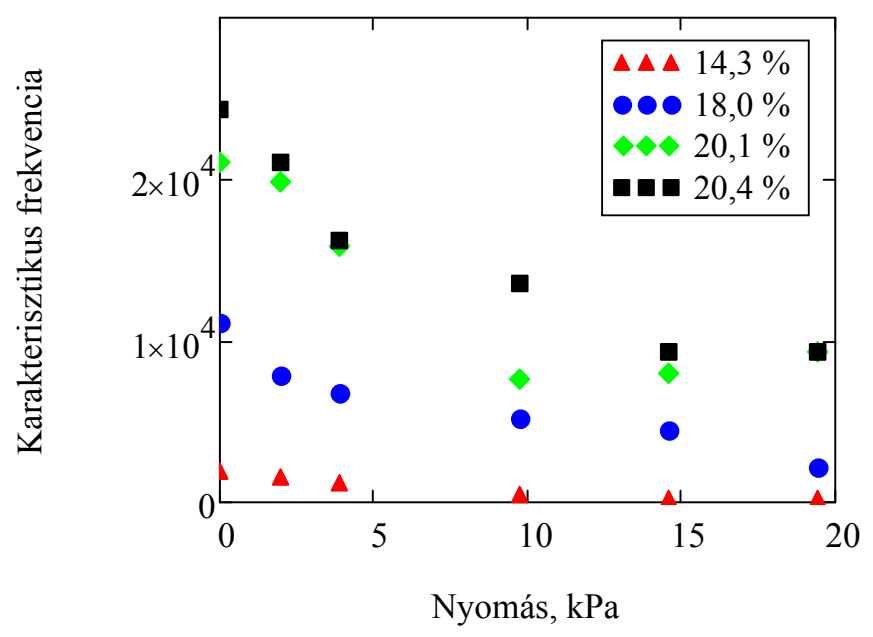

54. ábra Kukorica minták karakterisztikus frekvenciájának a nyomás függése módosított hengerkondenzátor esetén.

A karakterisztikus frekvencia a nyomás függvényében exponenciálisan csökken és a nedvességtartalom növekedésével nő. 


\subsection{MINTÁN BELÜLI EGYENLŐTLEN NEDVESSÉGELOSZLÁS}

Ebben az alfejezetben a száraz-nedves kukorica keverékekkel végzett mérések eredményei láthatók.

\subsubsection{Gabonaszemeken belüli egyenlőtlen nedvességeloszlás}

A nedvesen szárítóba került kukorica a szárítóközeggel érintkezve először melegedni kezd, majd a létrejövő nedvesség gradiens hatására megindul a víz leadása. A száradás során a szemeken belül inhomogén nedvességzónák alakulnak ki (Beke 1997). A szárítási folyamat végén a gabona nedvességtartalmának meghatározása dielektromos elven működő nedvességmérőkkel a szemeken belüli egyenlőtlen nedvességeloszlás miatt pontatlanná válhat. A 7. táblázat a kísérleteimben szereplő minták (dielektromos elven müködő, Burrows 700 nedvességmérővel mért és szárítószekrénnyel meghatározott) nedvességtartalmait tartalmazza szárítás után közvetlenül és 24 órával később, a minta kiegyenlítődése után.

7. táblázat A méréseim során használt kukorica minták nedvességtartalmai a szárítás előtt, közvetlenül a szárítás után, majd 24 órával később, a minta kiegyenlítődése után Burrows 700 típusú dielektromos nedvességmérővel. Minta hőmérséklet $21^{\circ} \mathrm{C}$

\begin{tabular}{|c|c|c|c|c|}
\hline $\begin{array}{c}\text { A minta kiindulási } \\
\text { nedvességtartalma } \\
\text { szárítószekrénnyel, } \\
\%\end{array}$ & $\begin{array}{c}\text { Szárítási } \\
\text { idő, } \mathrm{h}\end{array}$ & $\begin{array}{c}\text { (1) A minta nedvességtartalma száritás } \\
\text { után } \begin{array}{c}\text { Burrows } \\
700 \text { nedvességmérővel, } \\
\%\end{array}\end{array}$ & $\begin{array}{c}\text { (2) A minta nedvességtartalma } \\
\text { kiegy enlítődés után/ Burrows } 700 \\
\text { nedvességmérővel, \% }\end{array}$ & $\begin{array}{c}\text { Nedvességtartalom } \\
\text { különbség Burrows } \\
\text { nedvességmérövel, \% } \\
(2)-(1)\end{array}$ \\
\hline 22,9 & 1 & 18,96 & 18,93 & $-0,03$ \\
\hline 22,9 & 2 & 17,23 & 16,70 & $-0,53$ \\
\hline 25,4 & 1 & 19,66 & 20,90 & $+1,24$ \\
\hline 25,4 & 2,3 & 16,40 & 15,50 & $-0,90$ \\
\hline 25,4 & 3 & 15,66 & 14,60 & $-1,06$ \\
\hline 26,2 & 2 & 14,66 & 13,93 & $-0,73$ \\
\hline 26,2 & 3 & 11,96 & 11,53 & $-0,43$ \\
\hline 26,2 & 4 & 11,20 & 11,03 & $-0,17$ \\
\hline 26,2 & 5 & 10,03 & 10,36 & $+0,33$ \\
\hline 34,0 & 2 & 21,26 & 23,56 & $+2,30$ \\
\hline 34,0 & 3 & 20,10 & 21,30 & $+1,20$ \\
\hline
\end{tabular}

A táblázat adataiból kitünik, hogy míg a szárítószekrénnyel meghatározott nedvességtartalmak kiegyenlítődés előtt és után egyenlők, addig a Burrows 700 nedvességmérővel mért értékek pozitív és negatív irányban is eltérnek. Ez ellentétben áll az irodalomban közöltekkel, melyek szerint a dielektromos elven müködő nedvességmérök kisebbnek mérik a kiegyenlítetlen minta nedvességtartalmát.

A következőkben arra kerestem választ, hogy a szemeken belüli egyenlőtlen nedvességeloszlásnak milyen hatása van a dielektromos jellemzőkre. Az 55. ábrán egy 22,9 \%-os nedvességü kukorica minta relatív dielektromos görbéit ábrázoltam a frekvencia függvényében 1 és 
2 óra szárítás (és $22^{\circ} \mathrm{C}$-ra való lehülése) után és 24 órával a szárítást követően, amikor a nedvességtartalom a szemeken belül már kiegyenlítődött.
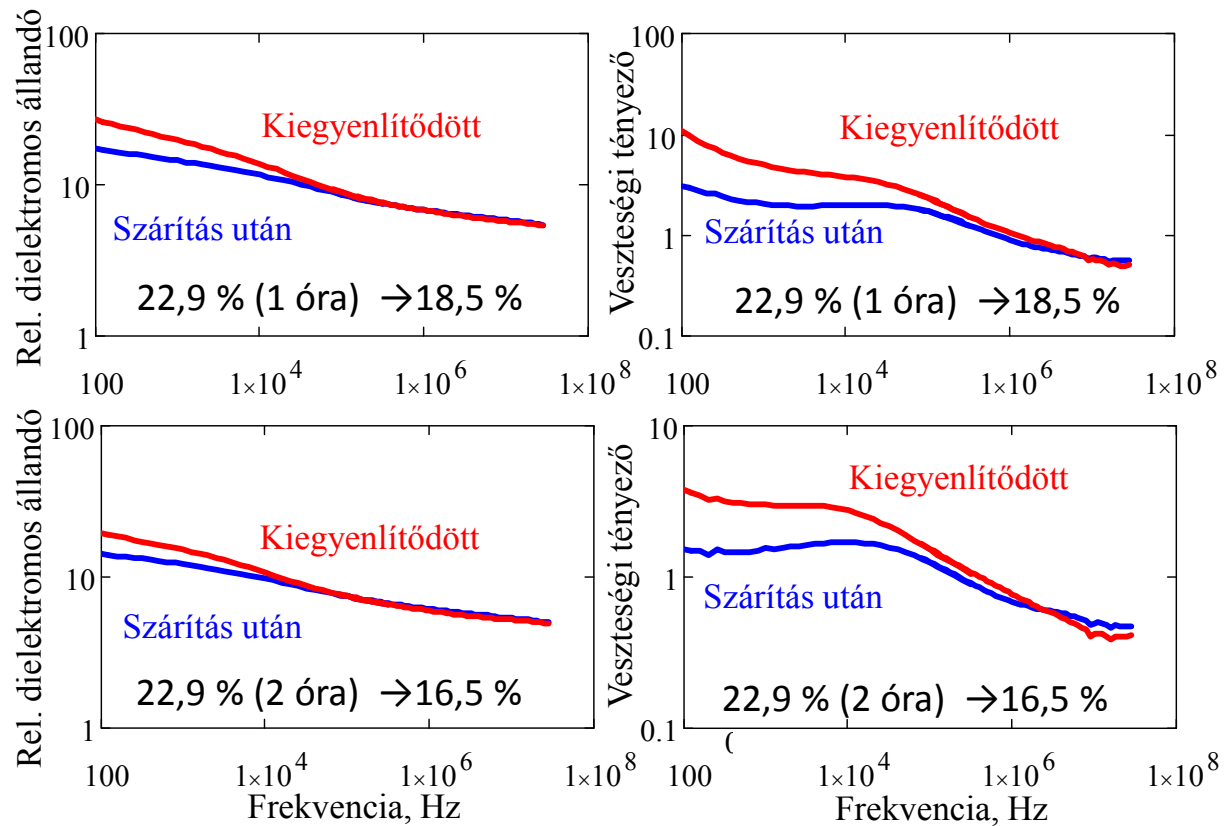

55. ábra Egy 22,9 \% nedvességtartalmú kukorica minta relatív dielektromos állandója és veszteségi tényezője (3 ismétlés átlaga) a frekvencia függvényében 1 óra és 2 óra szárítás után közvetlenül (kék) és kiegyenlítődés után (piros)

Az ábrán látható, hogy az 1 és 2 óra szárítás után mért relatív dielektromos állandó a $0,1 \mathrm{MHz}$ alatt kisebb, mint a kiegyenlítődés után mért relatív dielektromos állandó, és ez a különbség a frekvencia csökkenésével fokozatosan nő. A $0,1 \mathrm{MHz}$ feletti frekvenciatartományban a két relatív dielektromos állandó görbe közötti különbség fokozatosan eltünik. A veszteségi tényező 1 és 2 órás szárítás után kisebb $1 \mathrm{MHz}$ alatt, mint a 24 órával később, a kiegyenlítődés után. Az $1 \mathrm{MHz}$ feletti frekvenciatartományban a veszteségi tényező görbék metszik egymást, majd a frekvencia növekedésével a kiegyenlítődött minta veszteségi tényezője fokozatosan kisebb lett, mint az inhomogén mintáé. A szárítási idő növekedésével, azaz a szárítással elért nedvességtartalom különbség növekedésével a veszteségi tényező görbék metszéspontjának a helye a kisebb frekvenciák felé tolódott.

A kísérletet két nedvesebb mintán és hosszabb szárítási idővel megismételtem. Az 56. ábrán egy 25,4 \%-os nedvességü kukorica dielektromos görbéi láthatók. 

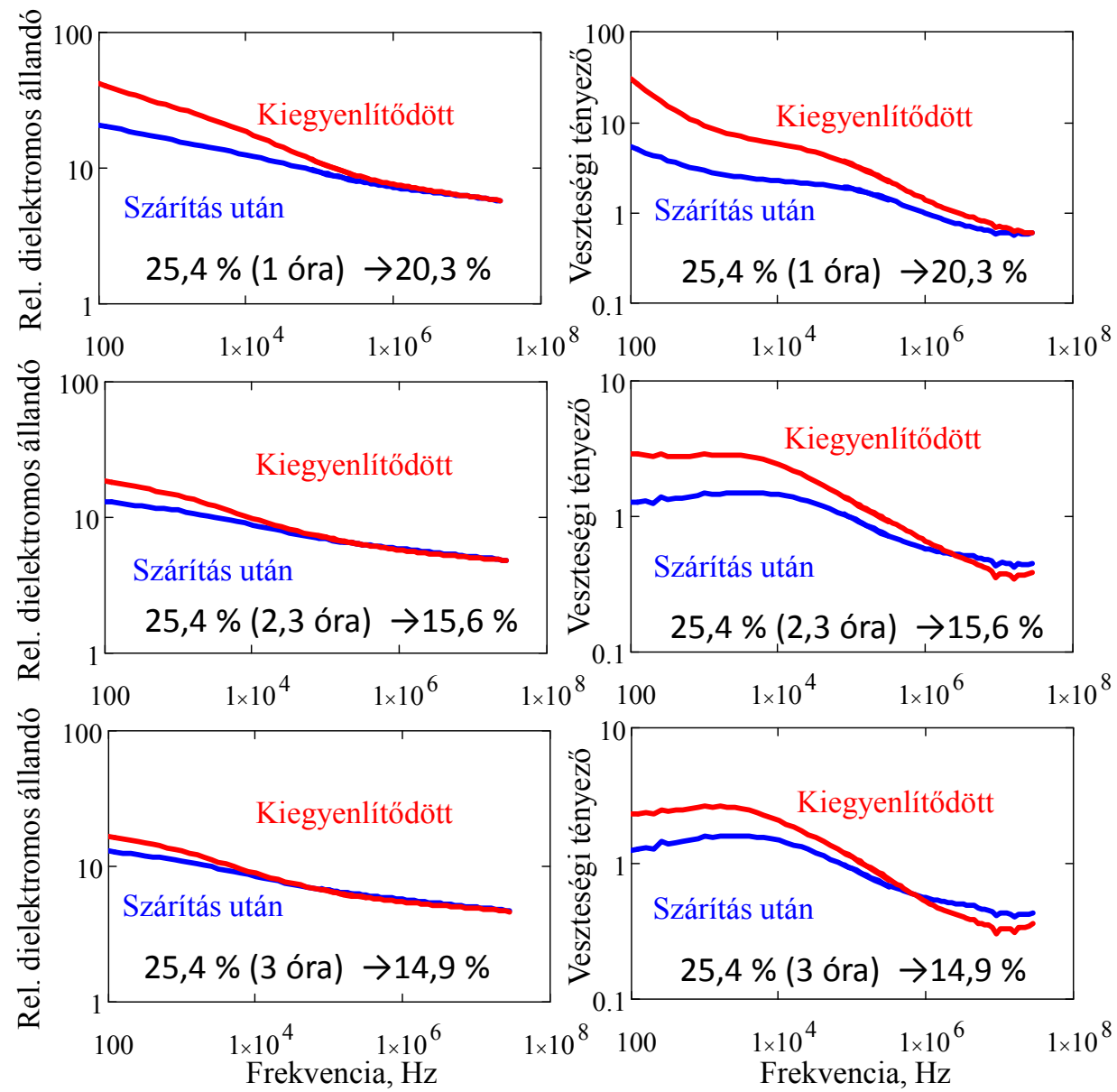

56. ábra Egy 25,4 \% nedvességtartalmú kukorica minta relatív dielektromos állandója és veszteségi tényezője (3 ismétlés átlaga) a frekvencia függvényében 1 óra, 2,3 óra és 3 óra szárítás (kék) majd 24 órával később, a kiegyenlítődés után (piros)

A 25,4 \%-os nedvességü kukorica minta kiegyenlítődés utáni relatív dielektromos állandó értékei 1 óra szárítás után $1 \mathrm{MHz}$ alatt, 2,3 óra szárítás után $100 \mathrm{kHz}$ alatt, 3 óra szárítás után $10 \mathrm{kHz}$ alatt nagyobbak, és e frekvenciák felett közel egyenlők a szárítás után mért relatív dielektromos állandó értékekkel. A két relatív dielektromos állandó görbe közötti eltérés a mérőfrekvencia csökkenésével nő, de a szárítási idő növekedésével csökken. Az inhomogén és a kiegyenlítődött minta relatív dielektromos állandó értékei közötti különbség eltünésének helye a szárítási idő növekedésével a kisebb frekvenciák felé tolódik. A kiegyenlítődött minta veszteségi tényező értékei a frekvencia és a szárítási idő függvényében nagyobb, egyenlő vagy kisebb, mint a közvetlenül a szárítás után mért minta veszteségi tényezőjének az értékei. A két görbe metszéspontjának a helye a szárítási idő növekedésével a kisebb frekvenciák felé tolódik. A veszteségi tényezö görbék metszéspontjához tartozó frekvenciánál kisebb frekvenciákon a kiegyenlítődött minta veszteségi tényező értékei egyre nagyobbak a frekvencia csökkenésével, de a szárítási idő növekedésével a kiegyenlítődött és az 
inhomogén minták görbéi közötti különbség nagysága csökken. A veszteségi tényező görbék metszéspontjához tartozó frekvenciánál nagyobb frekvenciákon a kiegyenlítődött minta veszteségi tényező értékei kisebbek, mint a közvetlen szárítás után mért mintáé. A következőkben egy 34 \% nedvességtartalmú kukorica mintán 10\%-nál nagyobb nedvességtartalom csökkenést idéztem elő 2 és 3 óra szárítással. Az eredményeket az 57. ábrán ábrázoltam.
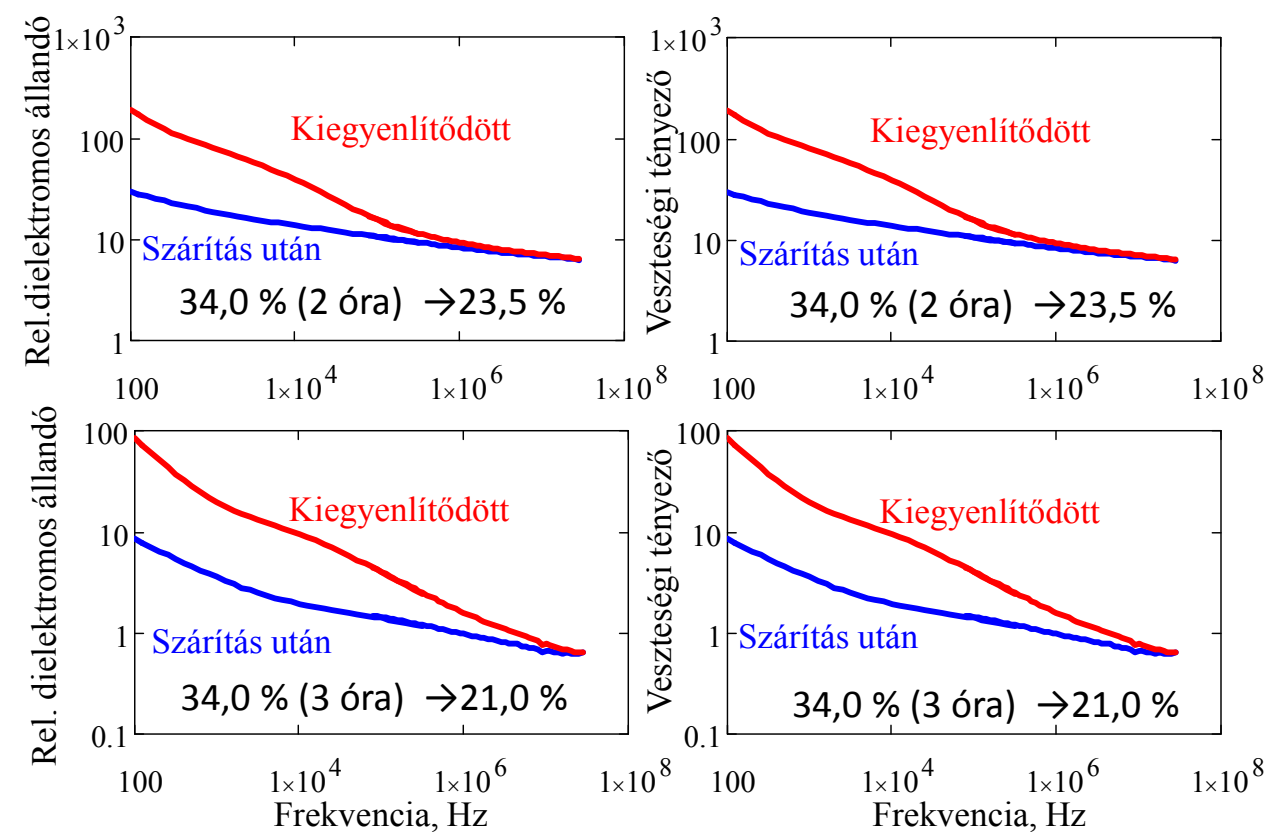

57. ábra Egy 34,0 \% nedvességtartalmú kukorica relatív dielektromos állandója és veszteségi tényezője (3 ismétlés átlaga) a frekvencia függvényében 2 óra és 3 óra szárítás után (kék) majd 24 órával később, a kiegyenlítődés után (piros)

Az ábrából megállapítható, hogy a szárítás által okozott (az előbbi két mintánál nagyobb nedvességtartalom csökkenés hatására) a közvetlenül szárítás után mért és a kiegyenlítődött minták relatív dielektromos állandó és veszteségi tényező görbéi közötti különbség nagyobb lett. Az a frekvencia, ahol a relatív dielektromos állandó és veszteségi tényező görbék különbsége közel nulla lesz a szárítási idő növekedésével a nagyobb frekvenciák felé tolódott. A relatív dielektromos állandóból a (34) nedvesség kalibrációs összefüggéssel kiszámítottam a kukorica minták nedvességtartalmát. Ábrázoltam a három ismétlés átlagából számított nedvességtartalom különbségeket (kiegyenlítődött mínusz szárítás után mért) a frekvencia függvényében (58. ábra): 


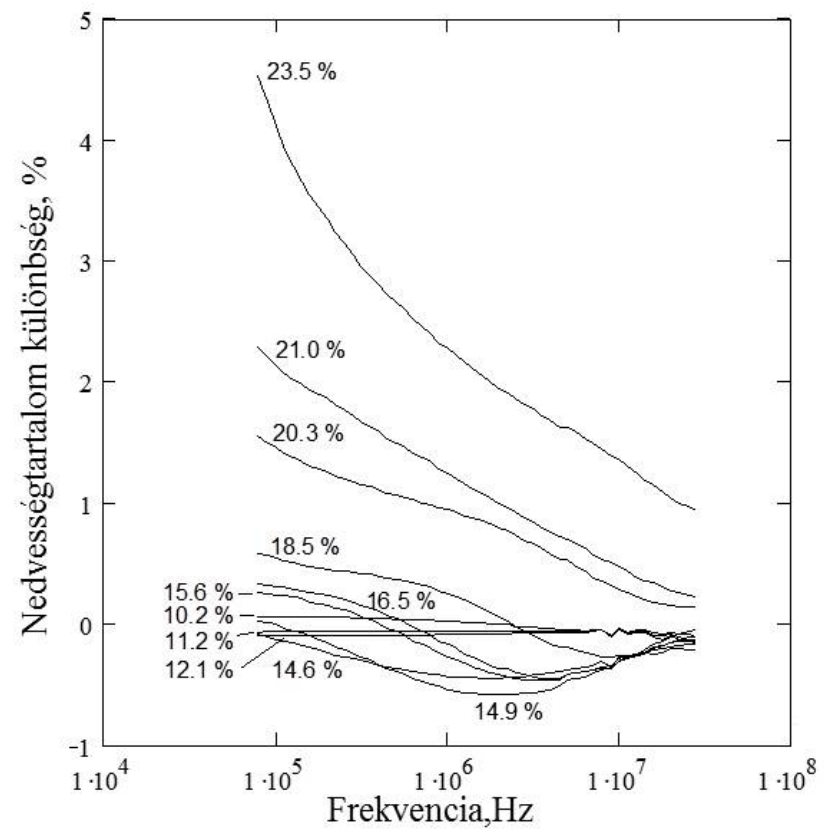

58. ábra A kiegyenlítődött és a szárítás után mért minták számított nedvességtartalmainak különbsége (3 ismétlés átlaga) frekvencia függvényében, az ipari mérési gyakorlat számára jelentős frekvenciatartományban. A görbéken a szárítás végén elért, szárítószekrénnyel meghatározott nedvességtartalmak találhatók.

A pozitív különbség jelentése, hogy a számított nedvességtartalom értéke nagyobb a kiegyenlítődött mintáknál, mint közvetlenül szárítás után. A legnagyobb különbséget a 34 \%-ról 23,5 \%-ra leszárított kukorica mintánál figyelhetjük meg. A számított nedvességtartalom különbség a $100 \mathrm{kHz}-10 \mathrm{MHz}$ közötti frekvenciákon maximum $\Delta \mathrm{M}_{\max }=+4,5 \%$ és $10 \mathrm{MHz}$ felett $\Delta \mathrm{M}_{\max }=+1 \%$. A 26,2\%-ról 3 és 4 óra alatt $12,1 \%$ és $10,2 \%$ nedvességtartalomra leszárított mintáknál a kiegyenlítődött és a szárítás után közvetlenül mért minták számított nedvességtartalom különbsége a teljes frekvenciatartományban elhanyagolható. A 14,6-18,5 \% nedvességtartalomra szárított mintáknál érdekes jelenséget figyelhettünk meg. A szárítás során elért végső nedvességtartalom csökkenésével a számított nedvességtartalom különbség egyre negatívabb lesz. A minimum elérése után (100 MHz körül) a frekvencia növekedésével értéke közelít a nullához.

A szakirodalomban az inhomogén nedvességeloszlás hatását a mért nedvességtartalom értékekre bár pozitív előjelűnek tüntetik fel, azonban eredményeim szerint a dielektromos nedvességmérők által használt 500 kHZ-10 MHz közötti frekvenciatartományban egyes esetekben az eltérés negatív is lehet. Így a szárítás után már lehült, de még inhomogén nedvességeloszlású minta nedvességtartalmát a dielektromos nedvességmérök a ténylegesnél nagyobbnak mérhetik. 
Az 59. ábrán a számított nedvességtartalom különbségeket ábrázoltam a minta végső, szárítószekrénnyel meghatározott nedvességtartalmának függvényében $200 \mathrm{kHz}, 2 \mathrm{MHz}$ és $20 \mathrm{MHz}$ frekvenciákon:

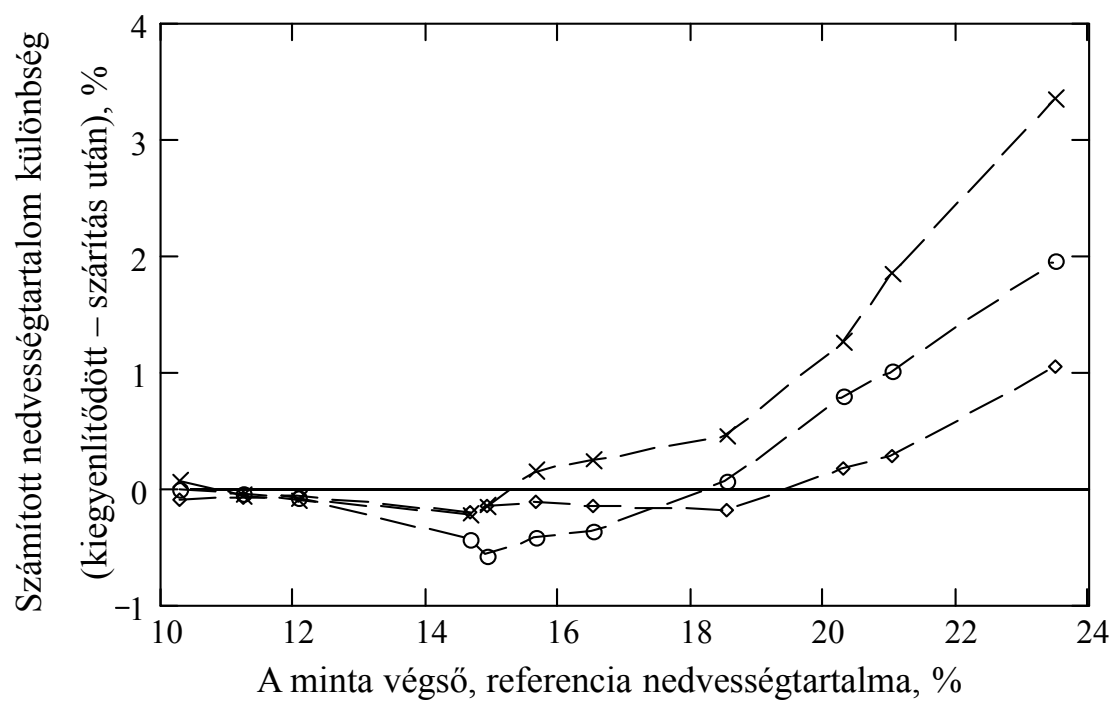

59. ábra Számított nedvességtartalom különbségek (kiegyenlítődött mínusz kiegyenlítetlen) a minta végső, szárítószekrénnyel meghatározott nedvességtartalmának függvényében $200 \mathrm{kHz}(X)$,

$$
2 \mathrm{MHz}(\circ) \text { és } 20 \mathrm{MHz}(\diamond) \text { mérőfrekvencián. }
$$

Az ábrán látható, hogy a gabonaszemeken belüli inhomogén nedvességeloszlás hatása a számított nedvességtartalom különbségre $20 \mathrm{MHz}$-en a legkisebb. A tárolási nedvességtartalom 14-16\%-os tartományában $2 \mathrm{MHz}$-en az eltérés negatív és értéke $\approx 0,5 \%$. A számított nedvességtartalom különbség nagysága függ a mérőfrekvenciától és a szárítással elért végső nedvességtartalomtól.

A továbbiakban arra kerestem választ, hogy kimutatható-e szignifikáns különbség a már kiegyenlítődött és az inhomogén nedvesség eloszlású minta között. A relatív dielektromos állandót és a veszteségi tényezőt a frekvencia függvényében ábrázolva e kérdésre nem lehet egyértelmüen válaszolni. A két állapot közötti különbség láthatóvá tétele érdekében az 55-57.ábrákon megjelenített adatokat Argand diagramokon ábrázoltam. A 60. ábrán a 22,9 \% nedvességtartalmú kukorica minta Argand ábrái láthatók 1 óra és 2 óra szárítás után, kiegyenlítetlen és kiegyenlítődött állapotban. 

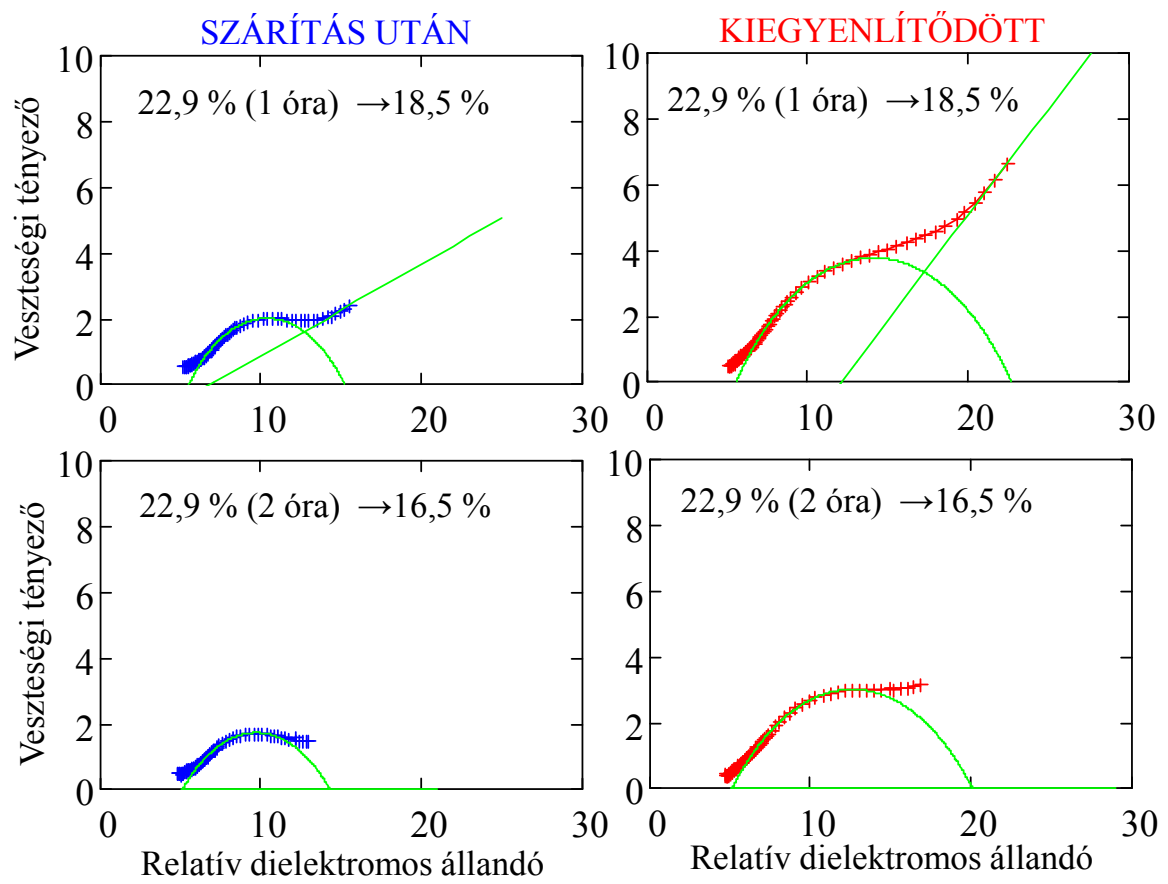

60. ábra Egy 22,9 \% nedvességtartalmú kukorica Argand görbéi (3 ismétlés átlaga) 1 óra és 2 óra szárítás és kiegyenlítődés után. Jelölések: kék - szárítás után, piros - kiegyenlítődött, zöld Mathcad 2010 programmal illesztett körív és egyenes

Az adott szárítási időnél a minta szárítás utáni és kiegyenlítődött állapotához tartozó Argand görbék alakja nagyon hasonló. Egy óra szárítás után a minta nedvességtartalma 18,5 \% lett, és ezen a nedvességtartalmon a Maxwell-Wagner relaxációt jellemző körív és az elektródpolarizációt jelző egyenes még látható a görbén. A kiegyenlítődött minta illesztett egyenesének meredeksége nőtt. Az Argand görbéket jellemző paraméterek közül a húrhossz (az illesztett körív és az x-tengely által meghatározott húr nagysága) megnövekedése a szembetűnő. Két óra szárítás után a minta görbéire már nem tudtam egyenest illeszteni, az elektródpolarizáció helyett a Maxwell-Wagner relaxáció dominálja a görbét. Hasonlóan az 1 óra szárításnál tapasztaltakkal a húrhossz közel kétszeresére nő.

A 61. ábrán a 25,4\% nedvességtartalmú kukorica minta Argand görbéi láthatók 1 óra, 2,3 óra és 3 óra szárítás után, kiegyenlítetlen és kiegyenlítődött állapotban. 

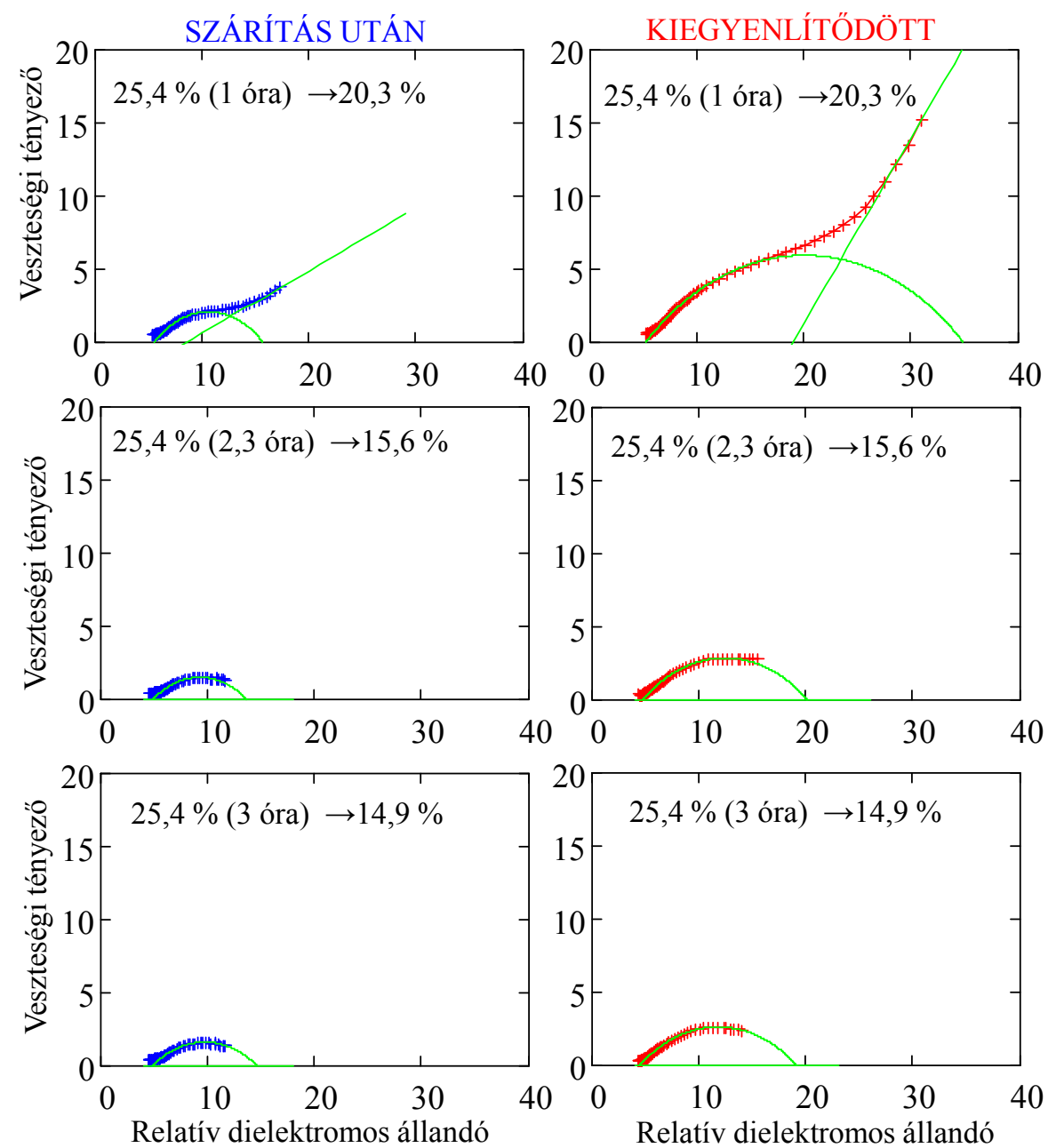

61. ábra Egy 25,4 \% nedvességtartalmú kukorica minta Argand görbéi (3 ismétlés átlaga) 1 óra, 2,3 óra és 3 óra szárítás és kiegyenlítődés után. Jelölések: kék - szárítás után, piros kiegyenlítődött, zöld - Mathcad 2010 programmal illesztett körív és egyenes

Az ábrán megfigyelhető, hogy a nedvességtartalomra jellemző Argand görbe alakja nem változott, de nagysága közel kétszeresére nőtt. Bár a szárítási idő növekedésével egyre nagyobb nedvességtartalom különbséget hoztam létre, ez nem okozta a szárítás utáni és a kiegyenlítődött minta Argand paraméterei közötti különbség növekedését.

A 34,0 \% nedvességü kukorica minta Argand ábráin is megfigyelhető az előző mintáknál tapasztalt jelenség, azaz az adott szárítási időhöz tartozó szárítás utáni és kiegyenlítődött minták Argand görbéinek alakja nem, de nagysága változott (62. ábra). 

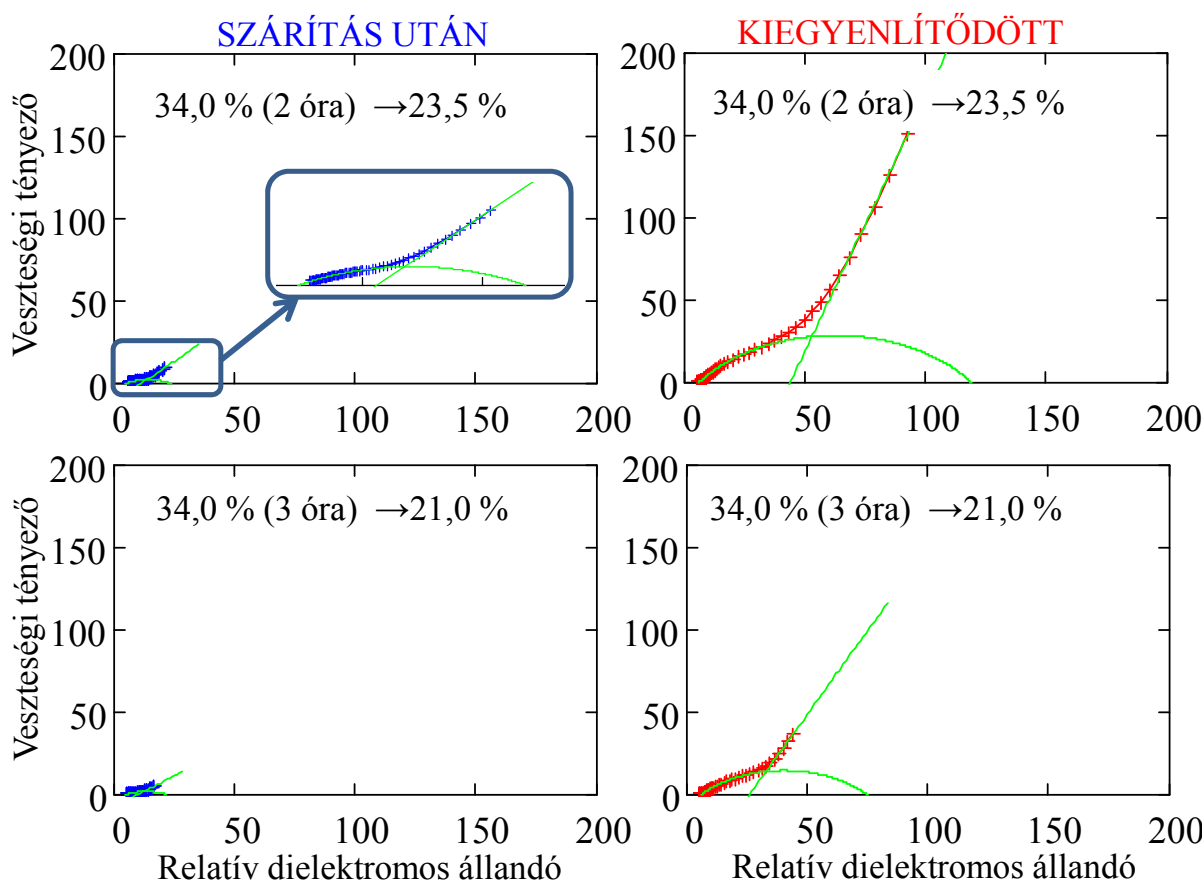

62. ábra Egy 34,0 \% nedvességtartalmú kukorica minta Argand görbéi (3 ismétlés átlaga) 1 óra,

2,3 óra és 3 óra szárítás és kiegyenlítődés után. Jelölések: kék - szárítás után , piros -

kiegyenlítődött, zöld - Mathcad 2010 programmal illesztett körív és egyenes. A kék négyzetekben az eredeti görbe és annak nagyítása látható.

A 60-62. ábrákból megállapítható, hogy a szárítás utáni és a kiegyenlítődött minta húrhossza közötti különbség a szárítási idő (és a kiindulási és a szárított nedvességtartalmak közötti különbség) növekedésével csökken.

A dielektromos görbéken $100 \mathrm{MHz}$ alatt megfigyelhető vezetési hatások közül az elektródpolarizáció nincs, vagy csak kis mértékben van jelen a száraz minták esetén. A MaxwellWagner relaxáció azonban száraz és nedves minta esetén egyaránt jelentkezik, így érdeklődésem középpontjában a Maxwell-Wagner relaxációt jellemző, illesztett körívből meghatározott paraméterek álltak, mint a húrhossz, a körív központi szöge és a karakterisztikus frekvencia. Feltételezésem szerint, e paraméterek segítségével kimutatható a szignifikáns különbség a szárítás utáni és a kiegyenlítődött kukorica minták dielektromos jellemzői között. A 63. ábra a 22,9\% \% a $25,4 \%$ és a 34,0 \% nedvességtartalmú kukorica minták húrhosszainak 3 ismétlésből származó átlaga és 95 \%-os konfidencia intervalluma látható különböző szárítási idő esetén. 

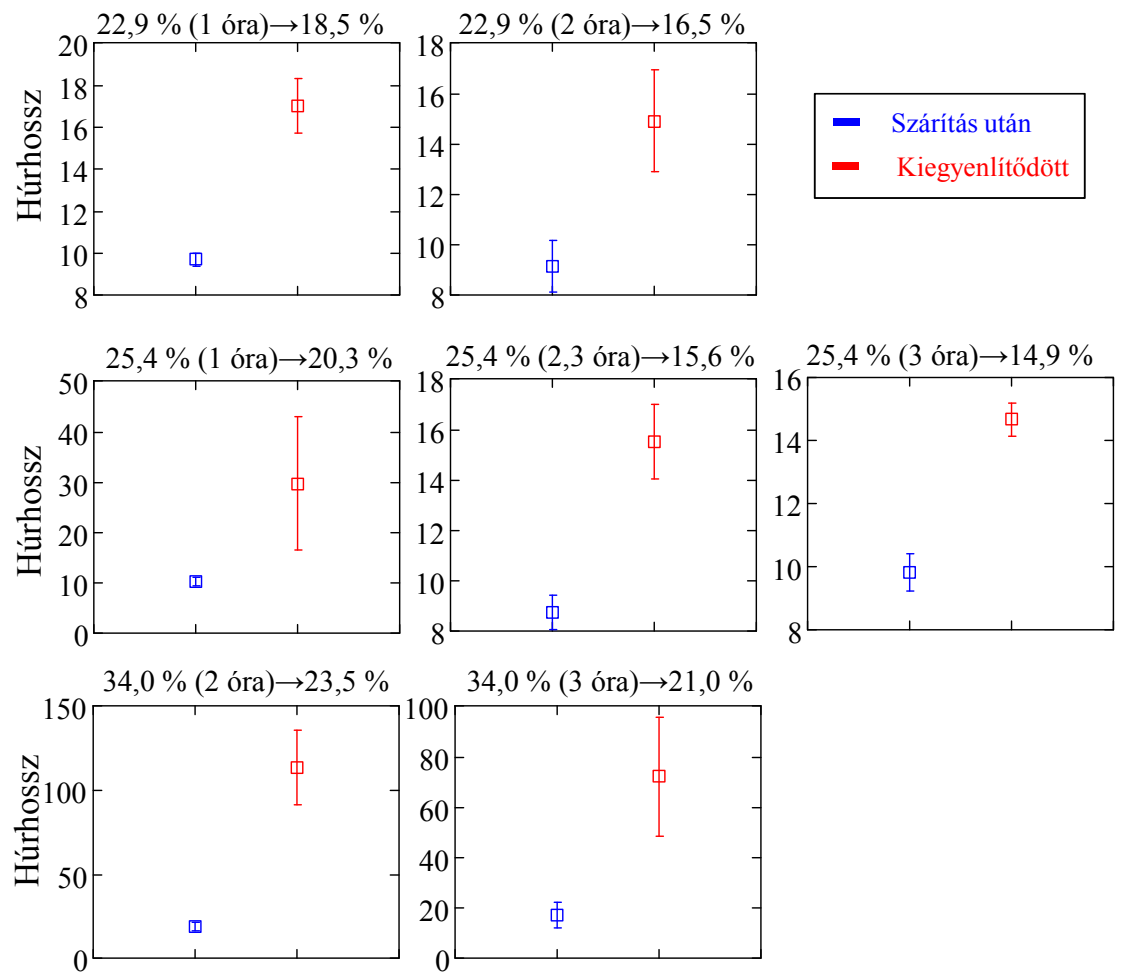

63. ábra A húrhossz átlaga (3 ismétlés) és $95 \%$-os konfidencia intervalluma 22,9\%, a 25,4\% és a 34,0 \% nedvességtartalmú kukorica minta és különböző szárítási idő esetén.

Az ábra alapján megállapítható, hogy 22,9 \% - 34,0 \% nedvességtartalmú kukorica szárítás utáni és a kiegyenlítődött minták húrhosszai között szignifikáns különbség van. A kiegyenlítődött minták húrhossz átlaga nagyobb és konfidencia intervalluma szélesebb volt (vagy közel egyenlő: a 25,4 \% minta 3 óra szárítása után), mint szárítás után az inhomogén nedvességeloszlású mintáké. Az illesztett körív központi szögének vizsgálata a 64 ábrán látható. 

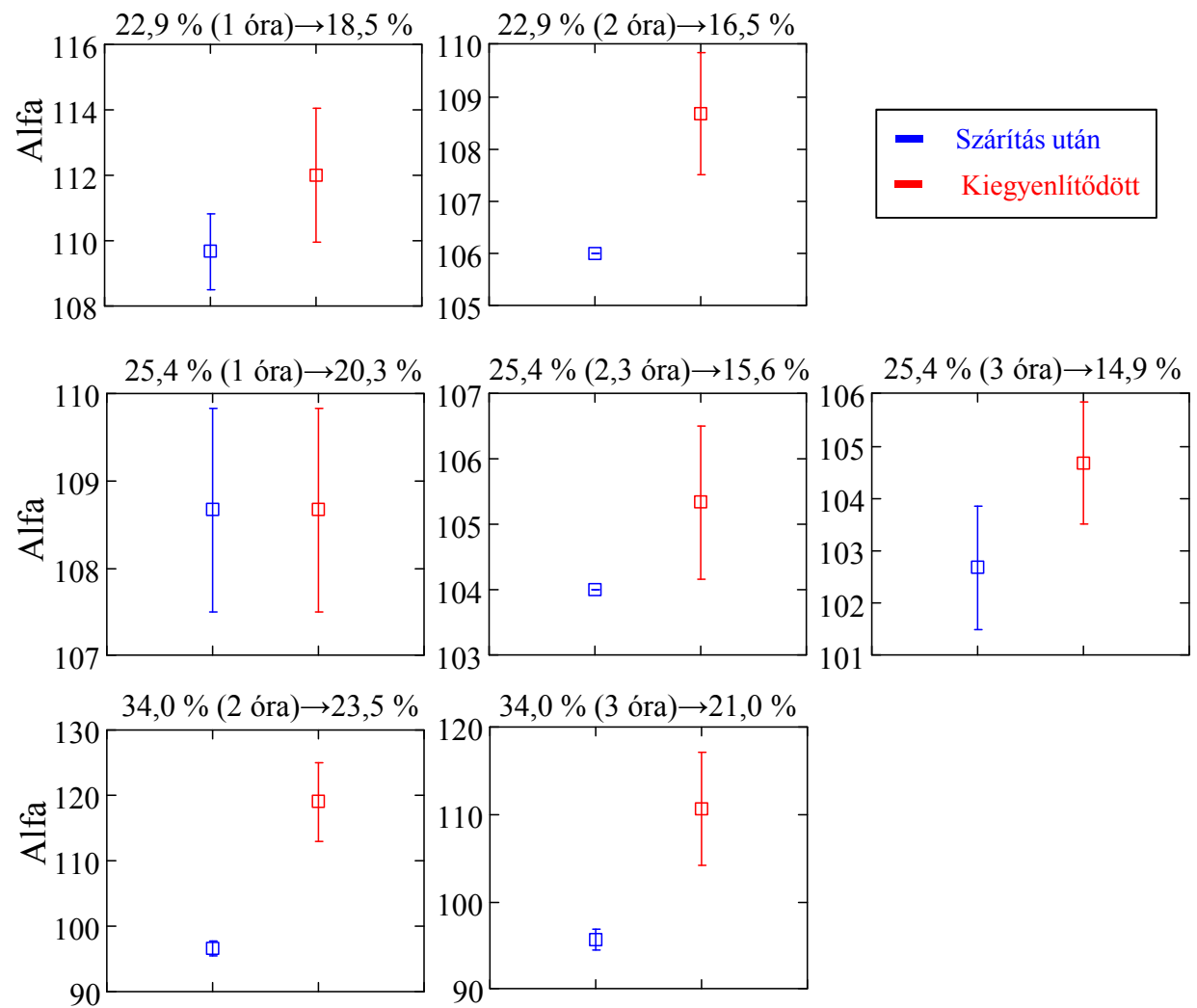

64. ábra Az illesztett körív központi szögének ( $\alpha$ ) átlaga (3 ismétlés) és 95 \%-os konfidencia intervalluma 22,9 \%, a 25,4 \% és a 34,0 \% nedvességtartalmú kukorica minta és különböző szárítási idő esetén.

A 34,0 \%-os nedvességü minta 2 és 3 óra szárítása után szignifikáns különbség mutatható ki a szárítás utáni és a kiegyenlítődött minták $\alpha$ értékei között. Szignifikáns a különbség a 22,9 \%-os minta 2 órás és a $25,4 \%$ nedvességü minta 2,3 óra szárítása után, de a többi esetben a különbség nem szignifikáns.

A 65. ábra tartalmazza a karakterisztikus frekvencia értékeinek elemzését, amely a MaxwellWagner csúcs helyét adja meg. 

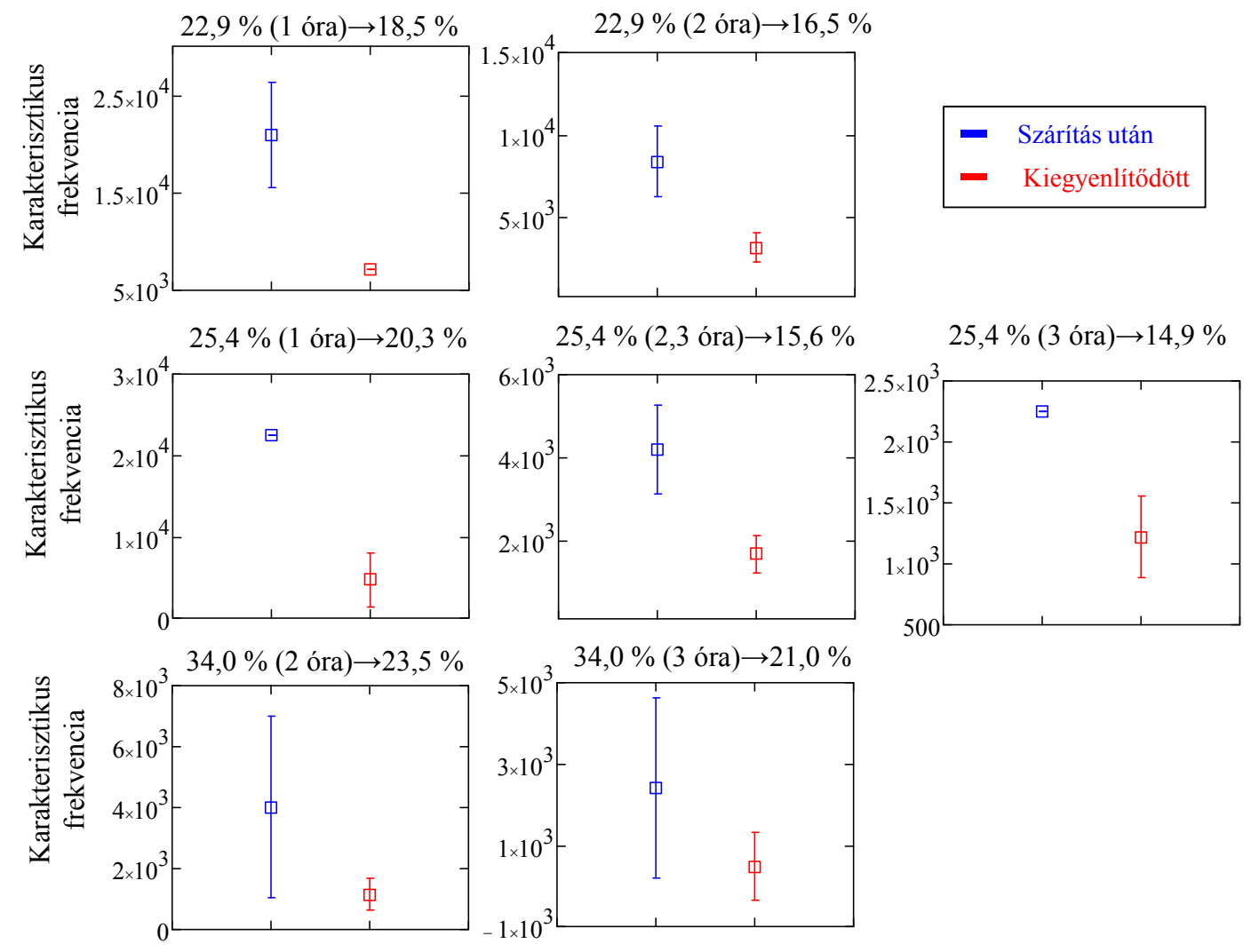

65. ábra A karakterisztikus frekvencia átlaga (3 ismétlés) és $95 \%$-os konfidencia intervalluma 22,9 \%, a 25,4 \% és a 34,0 \% nedvességtartalmú kukorica minta és különböző szárítási idő esetén.

A karakterisztikus frekvencia minden esetben csökkent a kiegyenlítődés után. Szignifikáns különbséget azonban csak a 22,9\%-os és a 25,4\%-os mintáknál figyelhetünk meg. Ez az eredeti Argand görbéket megnézve nem is meglepö, hiszen a nagyobb nedvességtartalmaknál az elektród polarizáció dominálja a dielektromos görbéket és a körív illesztése egyre bizonytalanabbá válik.

A korábbiakból levonható az a következtetés, hogy az illesztett paraméterek közül a húrhossz alkalmas az inhomogén nedvességeloszlású és a kiegyenlítődött minták szétválasztására.

\subsubsection{Száraz-nedves kukorica keverékek vizsgálata}

A 66. ábrán ábrázoltuk a $\mathrm{w}=33,9 \%$ nedves, és $\mathrm{w}=13,1 \%$ száraz kukoricaminták 50-50 \%-os keverékéből előállított három különböző tesztadag háromszori ismétlésének átlag relatív dielektromos állandóját és veszteségi tényezőjét a frekvencia függvényében, közvetlenül az összekeverés, és a kiegyenlítődés után. 


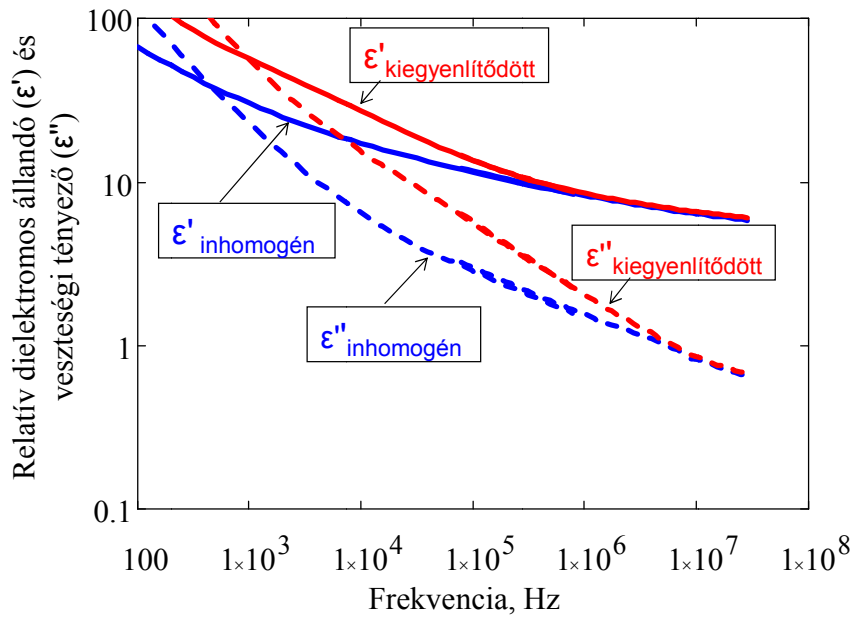

66. ábra Egy 23,1 \% keverék minta relatív dielektromos állandója és veszteségi tényezője a frekvencia függvényében kiegyenlítődés előtt $\left(\varepsilon_{\mathrm{ra}}, \varepsilon_{\mathrm{ra}}\right)$ és kiegyenlítődve $\left(\varepsilon_{\mathrm{rb}}^{\prime}, \varepsilon_{\mathrm{rb}}\right)$

A minták szabványmódszerrel meghatározott nedvességtartalma kiegyenlítődés előtt és után egyaránt 23,1\% volt, ezért azt vártuk, hogy a dielektromos spektrumokban sem lesznek szignifikáns különbségek. A dielektromos spektrumokban azonban $10 \mathrm{MHz}$ alatti frekvenciatartományban szignifikáns eltérések tapasztalhatók. A kiegyenlítődött minta relatív dielektromos állandója és veszteségi tényezője alacsony frekvencián nagyobb, a magasabb frekvenciatartományban kisebb, vagy egyenlő a kiegyenlítetlen mintához viszonyítva. Hasonló tendenciákat tapasztaltunk mind a nagyobb mind, pedig a kisebb nedvességtartalmú keverék mintáknál is. A dielektromos jellemzőkből számított nedvességtartalom különbségeket (kiegyenlítődés utáni nedvességtartalom mínusz kiegyenlítődés előtti nedvességtartalom) ábrázoltuk a frekvencia függvényében a 67 . ábrán.

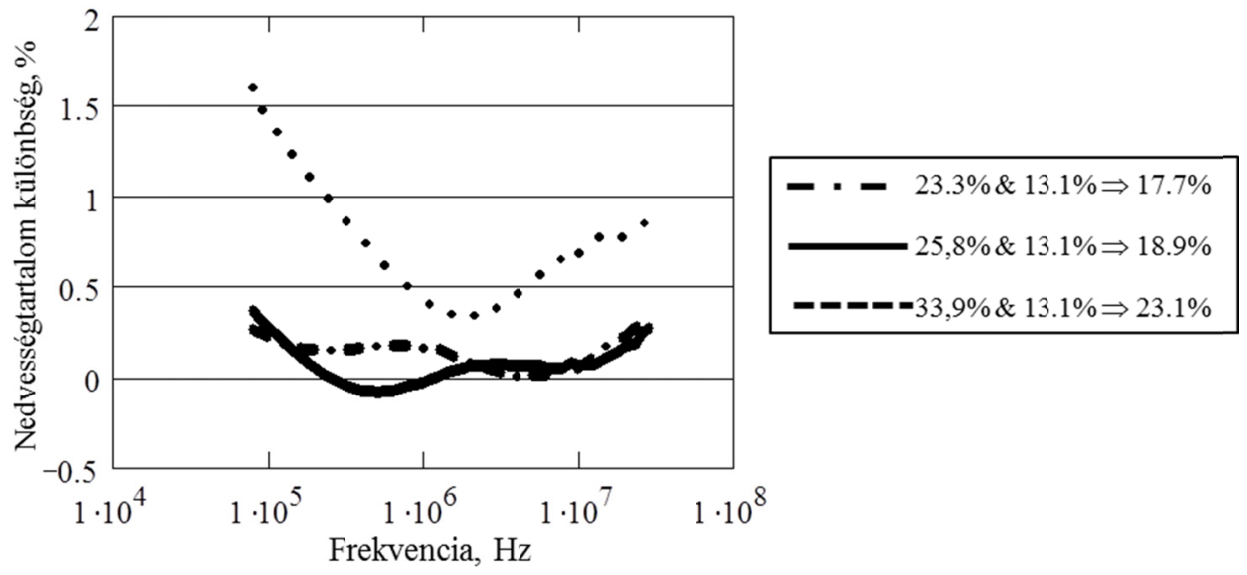

67. ábra A számított nedvességtartalom különbség (kiegyenlítődött mínusz a kiegyenlítetlen) különböző 50-50 \% arányú kukorica keverékek esetén. 
Mindhárom görbén megfigyelhető, hogy az eltérés nagyságát és előjelét a mérőfrekvencia és az eredeti minták közötti nedvességtartalom különbség határozza meg.

Felmerült a kérdés, hogy hasonló tendenciákat tapasztalhatunk-e, ha különböző nedvességtartalmú kukorica mintákat, szárazzal olyan arányban keverünk, hogy a keverék nedvességtartalma egy adott értékre legyen beállítva, vagy ha a keverékeket meghatározott arány szerint állítjuk elő.

A 68. ábra a különböző arányú keverékek eredményeit mutatja, amelyek a 16,5\%-os célnedvességre lettek keverve:
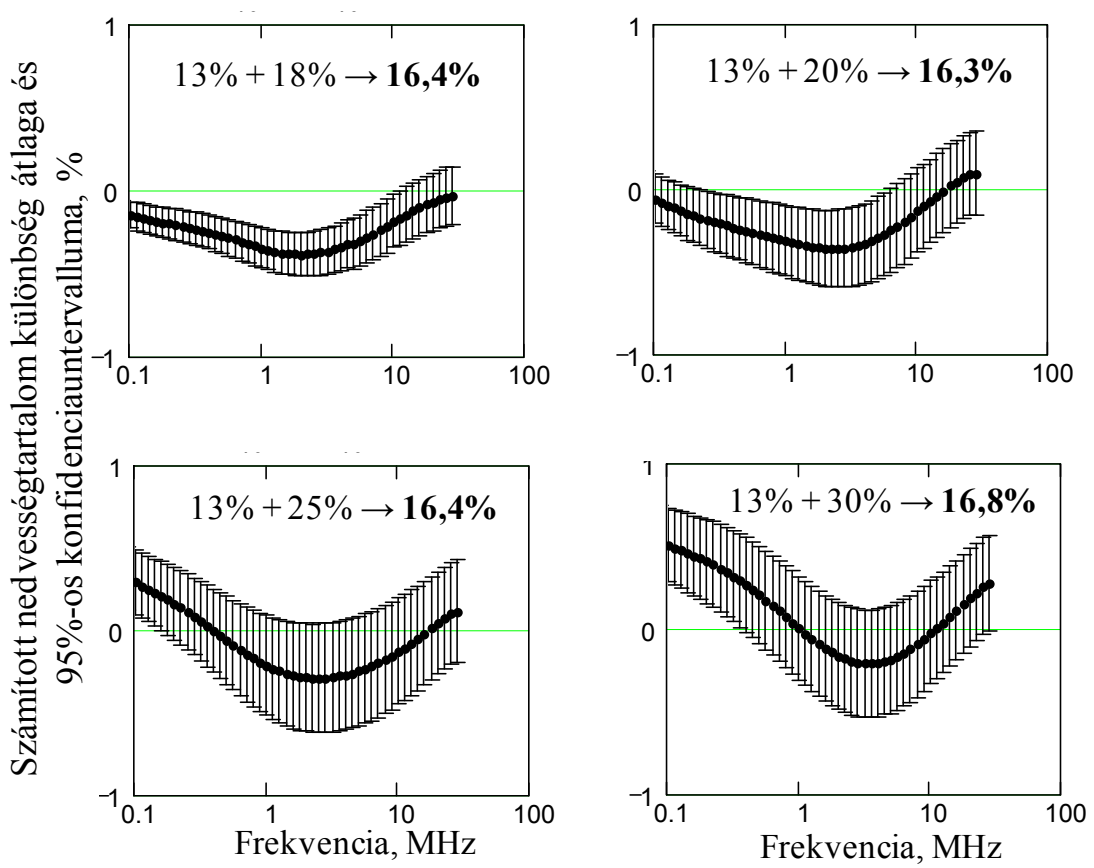

68. ábra Célnedvességtartalomra ( $\approx 16,5 \%$ az ábrán félkövér) beállított kukorica keverékek számított nedvességtartalom különbség (kiegyenlített mínusz kiegyenlítetlen) átlaga és 95 \%-os konfidencia intervalluma a frekvencia függvényében.

Megfigyelhető, hogy egyre nedvesebb kukoricát adva a keverékhez a számított nedvességtartalom különbségek pozitív irányba eltolódnak. A konfidencia intervallum szélesebbé válik a teljes frekvenciatartományban a keverék nedves alkotójának nedvességtartalmának növekedésével. Természetesen, a nedves alkotó aránya a nedvességtartalom növekedésével csökkent, azaz ugyanakkora célnedvesség eléréséhez kevesebb nedves kukoricára volt szükség. A 69. ábra együtt mutatja a 68. ábrán lévő értékek átlagát. 


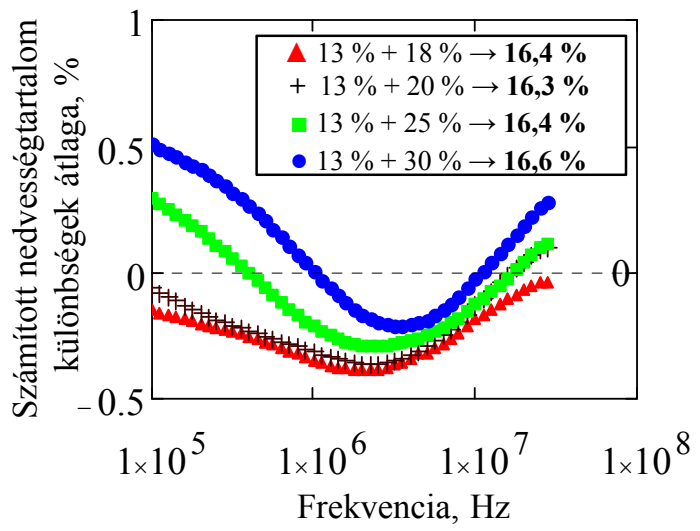

69. ábra A 68. ábrán látható célnedvességtartalomra $(\approx 16,5 \%)$ beállított kukorica keverékek számított nedvességtartalom különbség (kiegyenlített mínusz kiegyenlítetlen) átlaga a frekvencia függvényében.

Annak ellenére, hogy mind a négy minta végső nedvessége közel azonos, a becsült nedvesség különbség a kiegyenlítödött és kevert mintákra egy határozott módon változott attól függően, hogy milyen nedvességtartalmú mintát használtunk nedves komponensnek. A magasabb nedvességtartalmú nedves komponensekre a különbség az egész tartományon nött, de a görbék jellegzetes alakja megmaradt. A 70-72. ábra a 90:10, 75:25 és az 50:50 arányú keverékek eredményeit mutatja be:

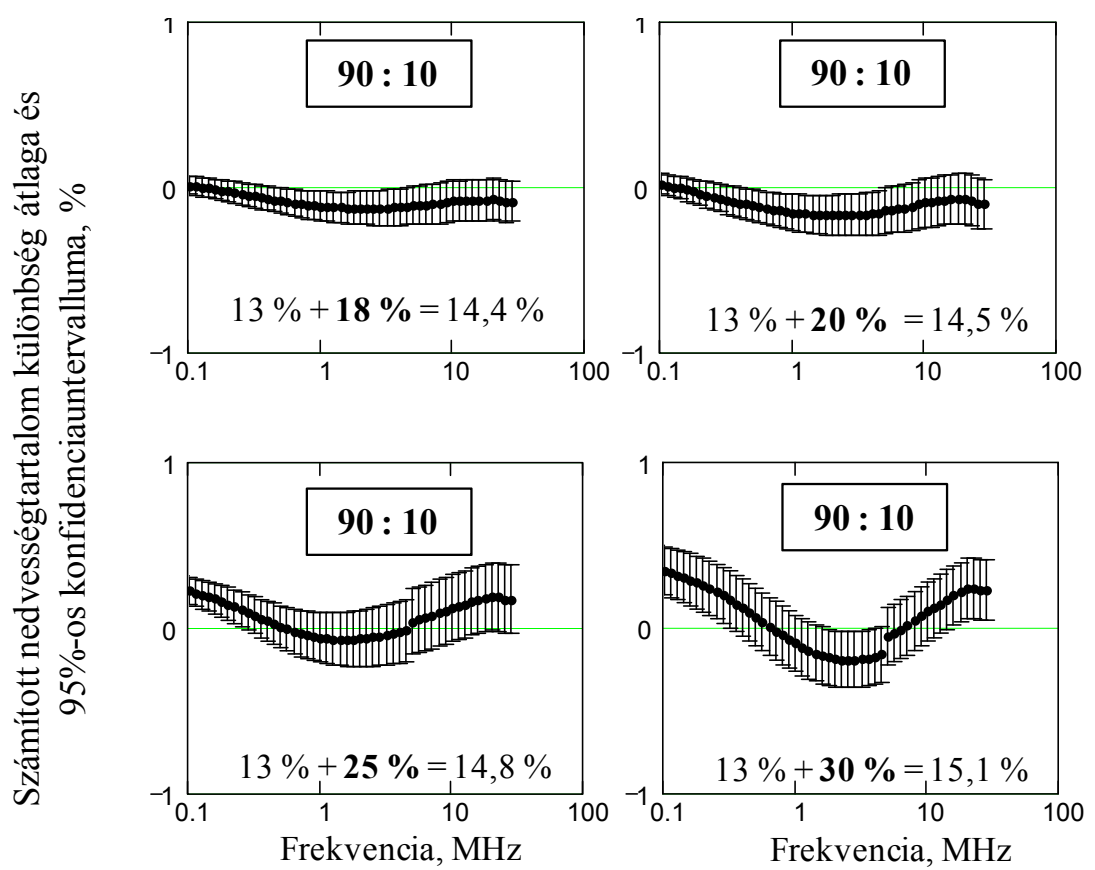

70. ábra A 90:10 arányú száraz-nedves kukorica keverékek számított nedvességtartalom különbség (kiegyenlített mínusz kiegyenlítetlen) átlaga és 95 \%-os konfidencia intervalluma a frekvencia függvényében. 

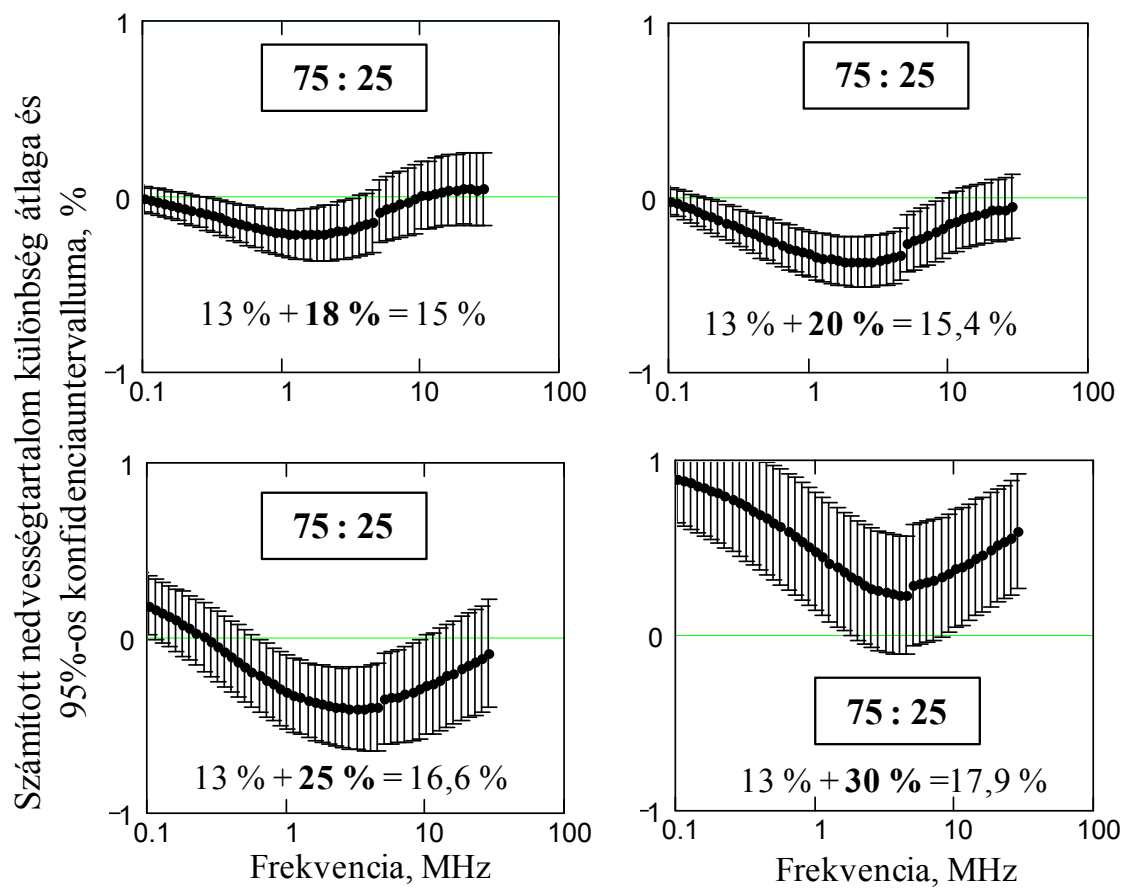

71. ábra A 75:25 arányú száraz-nedves kukorica keverékek számított nedvességtartalom különbség (kiegyenlített mínusz kiegyenlítetlen) átlaga és 95 \%-os konfidencia intervalluma a frekvencia függvényében.

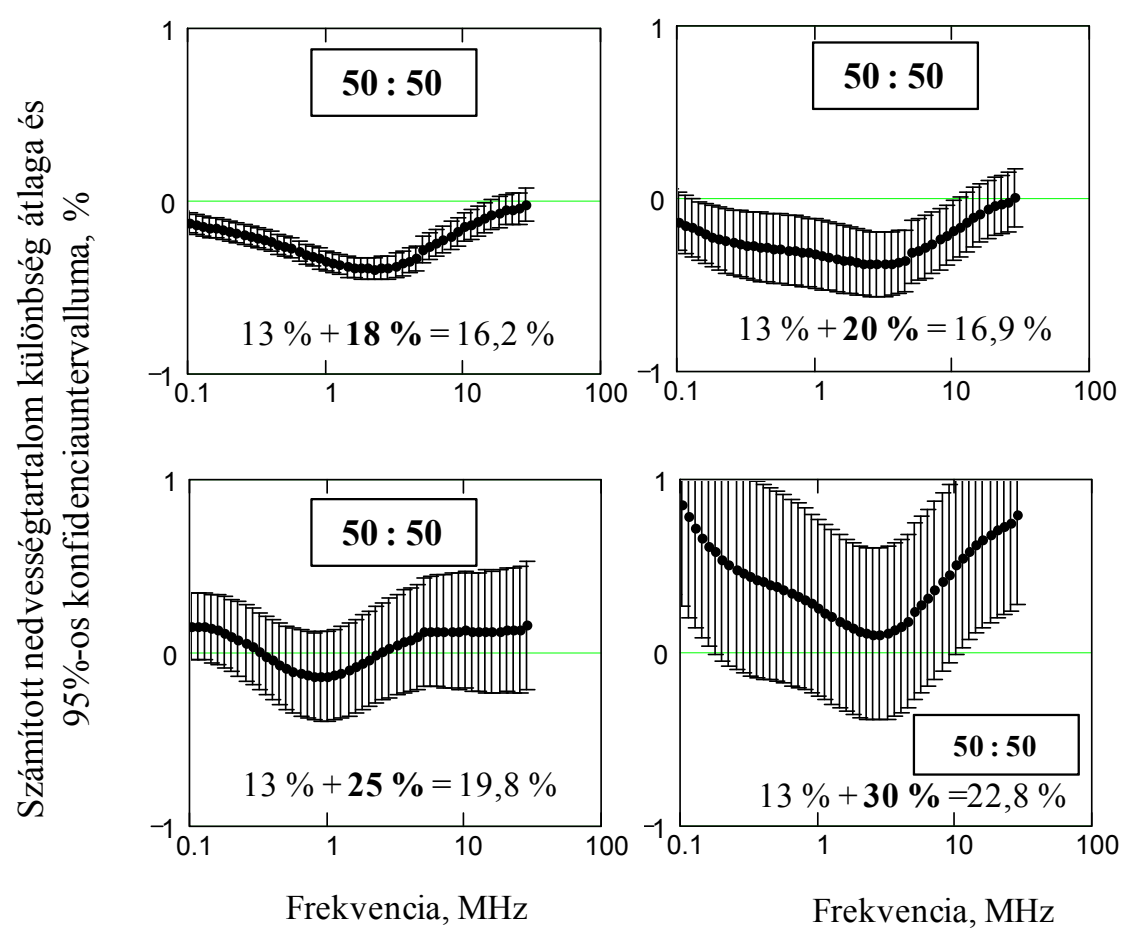

72. ábra 50:50 arányú száraz-nedves kukorica keverékek számított nedvességtartalom különbség (kiegyenlített mínusz kiegyenlítetlen) átlaga és 95 \%-os konfidencia intervalluma a frekvencia függvényében. 
Az ábrák hasonló tendenciákat mutatnak. Az 1-10 MHz frekvenciatartományban kisebb a számított nedvességtartalom különbség átlag (pontosabban az egyes mintákra levetítve, kevésbé pozitív vagy jobban negatív lett), mint a kisebb és nagyobb frekvenciákon. Ez a hatás kevésbé volt hangsúlyos azoknál a mintáknál, amelyek végső nedvességtartalma $15 \%$ alatt van. Megállapíthatjuk, hogy függetlenül a keverési aránytól a számított nedvességtartalom különbség átlagának konfidencia intervalluma növekvő tendenciát mutatott keverék nedves alkotórészének nedvességtartalmának növekedésével. A különbségek statisztikailag szignifikánsnak mutatkoztak (a konfidencia intervallumok nem tartalmazzák a nullát) a frekvenciatartomány legnagyobb részében, azokra a gabonákra, amelyek 18 és $20 \%$-os kukoricát tartalmaztak, de ugyanez nem volt igaz a 25 és $30 \%$-os nedves kukoricával készült keverékekre. A ábrákon látható görbék hasonló alakja azt sugallta, hogy megfelelö eljárással elkülöníthető a kiegyenlítetlen kukorica minta a már kiegyenlítődött halmaztól. Módszert dolgoztam ki a kiegyenlítetlen és a már kiegyenlítődött minták szétválasztására.

A minták elkülönítésére végzett diszkriminancia analízis eredménye a (38) másodfokú függvény lett:

$$
M_{28 M H z}-M_{5 M H z}=-0,01 \cdot\left(M_{28 M H z}-14\right)^{2}-0,18
$$

ahol $\mathrm{M}_{5 \mathrm{MHz}}$ a számított nedvességtartalom $5 \mathrm{MHz}$-en és $\mathrm{M}_{28 \mathrm{MHz}}$ a számított nedvességtartalom $28 \mathrm{MHz}-\mathrm{en}$.

A minta kiegyenlítődött ha:

$$
\mathrm{M}_{28 \mathrm{MHz}}-\mathrm{M}_{5 \mathrm{MHz}} \geqslant-0,01 \cdot\left(\mathrm{M}_{28 \mathrm{MHz}}-14\right)^{2}-0,18
$$

azaz megmérve a kukorica mintát $28 \mathrm{MHz}$ és $5 \mathrm{MHz}-\mathrm{en}$, és az így kapott nedvességtartalom értékeket kivonva egymásból, ha az így kapott eredmény nagyobb vagy egyenlő, mint $\mathrm{M}_{28 \mathrm{MHz}}-\mathrm{M}_{5 \mathrm{MHz}}$, akkor a minta már kiegyenlítődött, ha kisebb akkor inhomogén nedvesség eloszlású mintának volt besorolva.

A vizsgálataimban szereplő csak természetes és visszanedvesített, nedves alkotórészű kukoricából készült keverékeken alkalmazott módszer eredménye 73. ábrán látható: 

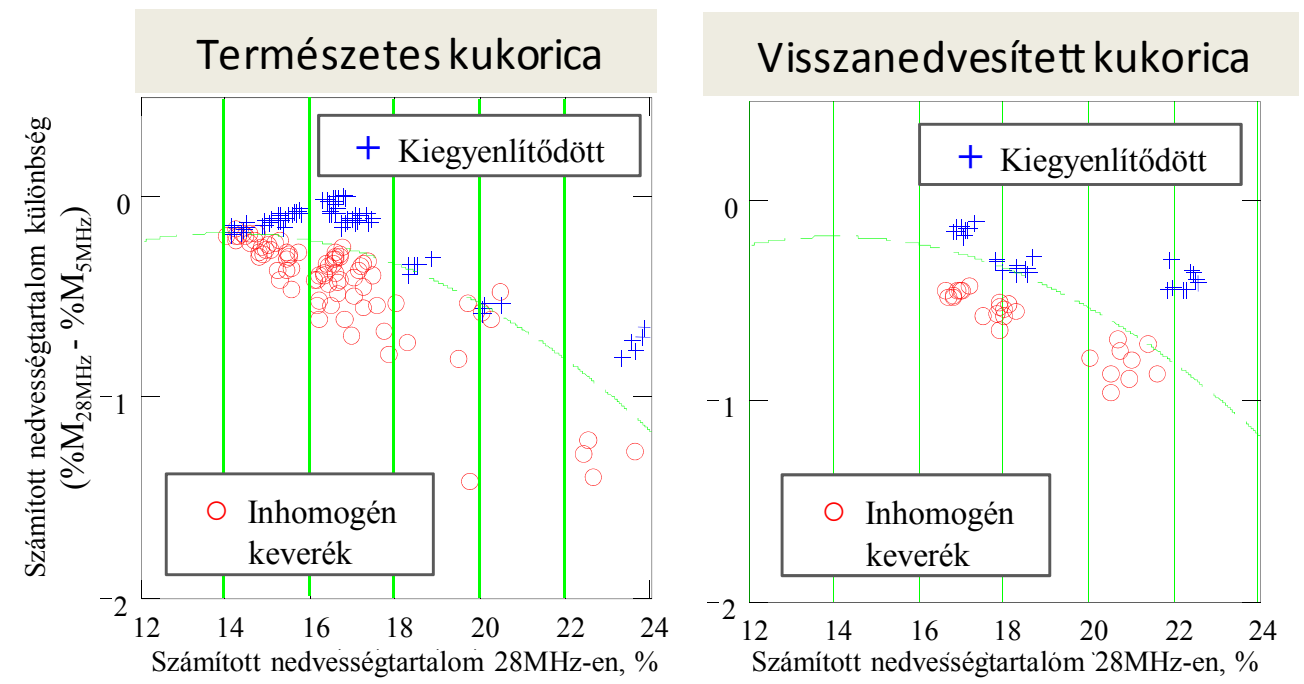

73. ábra Számított nedvességtartalom különbségek $28 \mathrm{MHz}$-en és $5 \mathrm{MHz}$-en inhomogén és homogén nedvesség eloszlású mintákra. A szaggatott vonal a másodfokú határt ábrázolja.

A 8. táblázat $\mathrm{Az}$ osztályozás sikeressége százalékosan a kiegyenlítetlen és a már kiegyenlített száraz-nedves kukorica keverékekre táblázat az osztályozás sikerességét mutatja meg a nem kiegyenlített minták detektálására. A módszer több mint 92 \%-os hatékonysággal azonosította a kevert és a kiegyenlítődött mintákat mind a mesterségesen nedvesített, mind pedig és a természetesen nedves mintákon.

8. táblázat Az osztályozás sikeressége százalékosan a kiegyenlítetlen és a már kiegyenlített száraz-nedves kukorica keverékekre

\begin{tabular}{lcccc}
\hline & \multicolumn{2}{c}{ Visszanedvesített } & \multicolumn{2}{c}{ Természetes } \\
\cline { 2 - 5 } & Keverék & Homogén & Inhomogén & Homogén \\
\hline Keveréknek ítélt & 92,5 & 6,2 & 96,2 & 7,7 \\
Homogénnek ítélt & 7,5 & 93,8 & 3,8 & 92,3 \\
\hline
\end{tabular}

\section{Inhomogén nedvességeloszlás fejezet összefoglalása:}

Egyenetlen nedvességeloszlás létrejöhet a különböző nedvességtartalmú magok között vagy a gyors szárítás hatására, a magokon belül. A hiba nagysága függ az mérőfrekvencia nagyságától, a szárítással elért nedvességkülönbség nagyságától és a keverékekben szereplő maghalmazok közötti nedvességtartalom különbségtől. Mindezen jelenségek magyarázatát a dielektromos spektrumokban jelentkező jellegzetes hatások összegződése okozza. A $28 \mathrm{MHz}$ alatti frekvenciatartományban 3 fö hatás jelentkezik.

Az első hatás az árnyékolási hatás. Ha gabonaszemeket kis kondenzátoroknak tekintve e jelenség könnyen megérthető. A száraz szemeknek kisebb a kapacitása, mint a nedveseké. Ha a 
száraz és a nedves gabonaszemeket sorba kötött kondenzátoroknak vesszük, akkor ez esetben az eredő kapacitás kisebb, mint a legkisebb kapacitás, azaz a száraz gabonaszemek jelenléte az eredő kapacitást jelentősen csökkentik. A szárított gabona esetében a magokon belüli nedvesség különbség okozza ezt a jelenséget. Ez a magyarázata annak, hogy a kiegyenlítődött minta esetén a mért relatív dielektromos állandó nagyobb, mint a még kiegyenlítetlen mintáé.

A második hatás az elektród polarizációs hatás. Az elektródpolarizáció főleg az alacsony frekvenciákon jelentkezik, de nagy nedvesség tartalmú gabona esetén jelentős hatása van a néhány megahertzes tartományban is. Emiatt láthatjuk, hogy a nagyobb nedvességtartalmú mintáknál a Maxwell-Wagner relaxációra utaló körív szinte eltünik, és a görbén az elektródpolarizáció válik dominánssá, amit az illesztett egyenes nagymértékü megnövekedése jelzett.

A Maxwell-Wagner relaxáció a harmadik hatás. A relaxáció oka a mintán belüli nem egyenletes vezetőképesség. A dielektromos veszteségi csúcs nagysága és az ehhez tartozó frekvencia függ a magasabb vezetőképességü tartományok körüli réteg kapacitásától és a tartomány vezetőképességétől. A tartományok vezetőképességének csökkenésével az előbb említett csúcs az alacsonyabb frekvenciák felé tolódik. A nedves gabonaszemek a mintán belül és a nedvesebb belsővel rendelkező magok (keverékeknél) is tapasztalható a Maxwell-Wagner relaxáció. A nedvesség kiegyenlítődése csökkenti azon tartományok vezetőképességét, amelyek a relaxációt okozták és ezért látható alacsonyabb frekvencián a Maxwell-Wagner csúcs. Ha a Maxwell-Wagner csúcs frekvenciája a kiegyenlítetlen gabonában alacsonyabb, mint a mérés frekvenciája a kiegyenlítődés a mért adatok csökkenését okozza. Ha a frekvencia a mérési tartomány felett van, akkor a növekedésüket okozza.

Összefoglalva: a három hatás közül kettő, az árnyékolási hatás és az elektród polarizáció a relatív dielektromos állandó növekedését okozza, míg egy, a Maxwell-Wagner relaxáció az emelkedést vagy a csökkenést okozhatja, függően a kiegyenlítetlen mintától és a mérési frekvenciától. 


\section{6 ÚJ TUDOMÁNYOS EREDMÉNYEK}

\section{A Landau-Lifshitz, Looyenga sürüségkorrekció hatékonysága 100 MHz alatt}

1. Megmutattam, hogy a Landau-Lifshitz, Looyenga sürüségkorrekció a különböző betöltési módok által okozott sürüségkülönbségek hatását

a. $100 \mathrm{kHz}$ és $28 \mathrm{MHz}$ közötti frekvencia tartományban tesztcellától függetlenül eredményesen korrigálta 11,2 \% - 31,8 \% nedvességtartalmú kukorica mintákon,

b. $100 \mathrm{kHz}$ alatti frekvenciákon tesztcellától és nedvességtartalomtól függ, hogy milyen mértékben csökkenti a hiba nagyságát.

2. A hengerkondenzátor tesztcellával végzett méréseink alapján megállapítottam, hogy ha a tesztcella középső elektródja rövidebb, mint a külső elektródja, akkor a középső elektród mellett és felett kialakuló különböző mintasürüség miatt a Landau-Lifshitz, Looyenga sürüségkorrekció eredményessége jelentősen romlik. A gabona nedvességmérésében a sűrűségkülönbségek okozta hibák kiküszöböléséhez elengedhetetlen és alapvető a minta pontos sürüségének ismerete a tesztcella elektromosan aktív részében.

3. Bizonyítottam, hogy a terhelés hatására szignifikáns különbség jött létre a dielektromos jellemzőkben $100 \mathrm{~Hz}-28 \mathrm{MHz}$ közötti frekvencia tartományban. Megmutattam, hogy a dielektromos jellemzők megváltozásának oka nem a nyomás hatására létrejött sürüségkülönbség, hanem a mintában erőteljesebbé vált vezetési hatások. Az ezen hatások által a dielektromos gabona nedvességmérésben okozott hibák kiküszöbölésére a LandauLifshitz, Looyenga sürüségkorrekció nem alkalmas.

\section{Dielektromos jellemzők Argand görbéje}

4. Megállapítottam, hogy a gabonák Argand görbéi tesztcellától függetlenül leírhatók a Maxwell-Wagner relaxációt jellemző körív és az elektród polarizációt jellemző egyenes kombinációjával 100 kHz-28 MHz közötti frekvencia tartományban az alábbiak szerint:

a. $14 \%$-os nedvességtartalom alatt kukorica és szója minta esetén csak körívvel,

b. kukorica esetén $14 \%$ - 35,2 \%, szója esetén $14 \%$ - 22,9 \% nedvességtartalom között egy körívvel és egy egyenessel. 


\section{A nyomás hatása}

5. Megállapítottam, hogy terhelés hatására gabona fajtól, tesztcellától és nedvességtartalomtól függetlenül a Maxwell-Wagner relaxációra és az elektród polarizációra jellemző frekvencia tartományok eltolódnak. A nyomás és a minta nedvességtartalmának növekedésével az elektród polarizáció dominánssá válik a dielektromos görbéken.

6. Megállapítottam, hogy tesztcellától függetlenül, a nyomás hatására a 11,2 \%-36,9\% nedvességtartalmú kukorica minták Argand ábráinak jellemző képe nem változik, de az illesztett kör átmérője és az illesztett egyenes szakasz hossza a terhelés nagyságának növekedésével nő.

7. Módosított hengerkondenzátor tesztcella esetén a nedvességtartalomtól független, lineáris összefüggést találtam a 14,3 \% - 20,4 \% nedvességtartalom közötti kukorica minták Argand görbéire illesztett körívből meghatározott húrhossz és a nyomás között. A köztük lévő függvénykapcsolat:

Húrhossz=1,114·Nyomás $+12,633$

a determinációs együttható 0,954 .

\section{Száraz-nedves kukorica keverékek}

8. A száraz-nedves kukorica keverékek kiegyenítődés utáni és kiegyenlítődés előtti számított nedvességtartalom különbsége függ a keverék nedves komponensének nedvességtartalmától és a mérési frekvenciától.

9. Módszert dolgoztam ki száraz-nedves kukorica keverék inhomogén és kiegyenlítődött állapotának megkülönböztetésére. Eszerint a száraz-nedves kukorica keverék $5 \mathrm{MHz}$ és $28 \mathrm{MHz}$ frekvencián mért relatív dielektromos állandójának ismeretében a kiegyenlítődött keverék megkülönböztethető az inhomogéntól 92\%-os hatékonysággal a következő kritériummal:

A minta kiegyenlítődött ha:

$$
\mathrm{M}_{28 \mathrm{MHz}}-\mathrm{M}_{5 \mathrm{MHz}} \geqslant-0,01 \cdot\left(\mathrm{M}_{28 \mathrm{MHz}}-14\right)^{2}-0,18
$$

\section{Szemeken belüli egyenlőtlen nedvesség}

10. Bebizonyítottam, hogy a szárítás hatására a gabonaszemekben létrejövő egyenlőtlen nedvességeloszlás szignifikáns a különbséget okoz az Argand ábrán a Maxwell-Wagner relaxációra jellemző húrhossz értékében, ez alapja lehet egy konkrét kiegyenlítetlen/kiegyenlítődött szétválasztási küszöb meghatározásának 


\section{KÖVETKEZTETÉSEK ÉS JAVASLATOK}

A kukorica és szója minták dielektromos görbéit elemezve megállapítottam, hogy elektród polarizáció és a Maxwell-Wagner relaxáció az, ami meghatározza a dielektromos jellemzőket a $100 \mathrm{~Hz}-28 \mathrm{MHz}$ frekvenciatartományban. A kukorica és szója Argand görbéi leírhatók egy egyenes és egy körív kombinációjával kukorica esetén $31,0 \%$ és szója esetén 22,9\% alatti nedvességtartalmakon. Javaslom a további méréseket széles frekvencia tartományban kukorica és szója mintákon elvégezni és ezáltal az Argand görbék illesztett paramétereinek segítségével meghatározni, hogy mely frekvencia tartományokban van a Maxwell-Wagner relaxációnak és elektród polarizációnak jelentősége.

További mérések elvégzését javasolom a tesztcella anyagának és alakjának az elektród polarizációra való hatásának vizsgálatához.

Dolgozatomban nem vizsgáltam a hőmérséklet hatását, ezért új kutatási célnak javaslom, mert további információkat szolgáltathat a vezetési hatások jobb megértéséhez és ezáltal a dielektromos viselkedés teljesebb és pontosabb matematikai modelljének megalkotásához a megaherz alatti frekvenciatartományban.

Javaslom az on-line rendszerekben előforduló nyomás-tartománynak a meghatározását, és eredményeim felhasználásával korrekciós összefüggést fejlesztését e tartományra.

Az inhomogén nedvességeloszlás keverékek és szárított minták esetében is hatással van gabonaminták dielektromos jellemzőire. Javaslom egy robosztusabb diszkriminancia függvény kifejlesztését a száraz-nedves gabona keverékek meghatározására, majd megvizsgálni, hogyan alkalmazható módszer különböző gabona fajokra és tesztcella típusokra.

További mérések elvégzését javaslom a szárított és kiegyenlítődött minták Argand görbéiből nyert húrhossz segítségével történő elválasztásának finomításához. Kiterjeszteni a módszer alkalmazását kukoricán kívül más gabonára is. 


\section{7 ÖSSZEFOGLALÁS}

A nedvességtartalom az egyik legfontosabb minőségi jellemzője a szemesterményeknek, és bár a nedvességmérőknek közel 100 éves múltja van, még mindig számos megoldatlan kérdés nehezíti a pontos nedvességmérők megalkotását. A nedvességmérők nem közvetlenül a víztartalmat mérik, hanem egy víztartalomtól függő jellemzőt. A mérési pontosság igen sok tényező függvénye. Az olyan mérési eljárások, amelyeket e zavaró tényezők alig befolyásolnak azonban viszonylagos bonyolultságuk, magas költségeik miatt az iparban nem terjedtek el. A kapacitív elven müködő berendezések pontosak és méréstechnikájuk egyszerübb, mint a nagyobb frekvenciákon működő berendezéseknek. A nedvességmérő gyártók gazdaságossági törekvései miatt még mindig van érdeklődés a gabonák $100 \mathrm{MHz}$ alatti tulajdonságai iránt. Ezért kutatásom célja, az online mérésekben, szárítókban, kombájnon előforduló zavaró tényezők dielektromos görbékre gyakorolt hatásának meghatározása volt.

Kutatásom két fö területre irányult. Egyik a halmaztömörödöttség különbségeket okozó hatások, mint különböző betöltési módok és a nyomás dielektromos görbékre gyakorolt hatása és kompenzálásuk lehetőségei Landau-Lifshitz, Looyenga sürüségkorrekcióval. Másik a gabonahalmaz inhomogén nedvesség eloszlásából származó hibák meghatározása és módszerfejlesztés a kiegyenlítetlen gabona kimutatására.

Megállapítottam, hogy a Landau-Lifshitz, Looyenga sürüségkorrekció $100 \mathrm{kHz}$ felett hatékony, de $100 \mathrm{kHz}$ alatt nem, vagy csak részben alkalmas a különböző halmaztömörödöttségből adódó különbségek kompenzálására. Megmutattam, hogy a nyomás megváltoztatja a gabonák dielektromos tulajdonságait és hatásában különbözik a rázástól. Míg a rázás hatására halmaztömörödöttség jön létre, a növekvő nyomás hatására a vezetési hatások erősödnek fel. Megállapítottam, hogy a változás leírására a húrhossz a legalkalmasabb paraméter, és meghatároztam a húrhossz és a nyomás függvénykapcsolatát. Bizonyítottam, hogy a nyomás hatása annak megszünése után is látható marad a dielektromos görbéken. Meghatároztam a kukorica keverékekben az inhomogén nedvességeloszlás által okozott nedvességmérési hibát $100 \mathrm{kHz}$ és 28 MHz között és kidolgoztam egy diszkrimináló módszert, amellyel 92\%-os hatékonysággal elkülöníthető a frissen kevert és a kiegyenlítődött minta relatív dielektromos állandó $5 \mathrm{MHz}$ és $28 \mathrm{MHz}$ történt mérésével. Meghatároztam a szárítás hatására létrejött inhomogén nedvességeloszlás miatt fellépő nedvességmérési hibát $100 \mathrm{kHz}$ és $28 \mathrm{MHz}$ között. Bizonyítottam, hogy szignifikáns különbség van a frissen szárított és a kiegyenlítődött minta húrhosszai között. Leíró módszert dolgoztam ki a $100 \mathrm{~Hz}-28 \mathrm{MHz}$ közötti vezetési hatások elkülönítésére 11,2%35,2 \%-os nedvességü kukorica és 8,8 \%-22,9 \%-os nedvességü szója mintákon. 


\subsection{SUMMARY}

Moisture content is one of the most important grain quality factors, and, despite the 100-year history of grain moisture meters, there are still several unanswered questions that impede the development of accurate moisture meters. Moisture meters do not directly sense moisture content but rather a moisture-dependent physical property. Their accuracy is dependent on numerous factors. Measurement systems affected minimally by these disturbing factors are not used widely in industry due to their complexity and high cost. Capacitive-type equipment are fairly accurate and the applied measurement technologies are simpler than the meters operating at high frequencies. For the financial endeavor of manufacturers designing low cost meters, there is interest in properties of grain below $100 \mathrm{MHz}$. For this reason the goal of my research was to investigate the effects of disturbing factors to dielectric spectra such as would occur in online measurements in grain driers and on combine harvesters.

My research was focused on two major topics. The first was the impact of the effects causing bulk density variation (such as different loading methods and pressure) on dielectric spectra and the possibility of compensation by the Landau-Lifshitz, Looyenga density correction. The second topic was to determine the error caused by inhomogeneous moisture distributions and to develop a method to identify non-equilibrated grain.

I have found that the Landau-Lifshitz, Looyenga density correction is effective above $100 \mathrm{kHz}$, but below $100 \mathrm{kHz}$ it is not capable or only partially capable of compensating the variation caused by different bulk densities. I demonstrated that the effect of compressing grain by applying pressure changed the dielectric properties of grain and was different from the effect of shaking to settle the grain. Shaking increases the density of bulk grain more than pressure, but increasing pressure results in stronger conductivity effects. I found that for describing these changes the most efficient parameter was the chord length computed from the Argand diagram, and I have defined the relationship between chord length and applied pressure. I have proved that the effect of pressure on the dielectric spectra remained after the pressure was removed. I have quantified the moisture prediction errors (for measurement frequencies between $100 \mathrm{kHz}$ and $28 \mathrm{MHz}$ ) caused by inhomogeneous moisture distribution for blended corn and I have developed a method to discriminate recently mixed and equilibrated samples with $92 \%$ effectiveness by measuring the dielectric constants at $5 \mathrm{MHz}$ and $28 \mathrm{MHz}$. I have determined the moisture prediction errors (for measurement frequencies between $100 \mathrm{kHz}$ and $28 \mathrm{MHz}$ ) as a result of inhomogeneous moisture distributions caused by drying. I have proved that there is significant difference between the chord

lengths measured for recently dried and equilibrated samples. I demonstrated a method to differentiate between conductivity effects for corn in the $11.2 \%-35.5 \%$ moisture range and for soybeans in $8.8 \%-22.9 \%$ moisture range. 


\section{MELLÉKLETEK}

\section{M1. IRODALOMJEGYZÉK}

Agilent Technologies (2006). Basics of Measuring the Dielectric Properties of Materials.

Bonifacio-Maghirang, E., M. R. Paulsen, L. D. Hill and K. L. Bender (1997): Single Kernel Moisture Variation and Fungal Growth of Blended Corn. Applied Engineering in Agriculture 13(1): 81-89.

Brenner, C. A., Z. Gillay, D. B. Funk and R. O. Pierce (2011): Limitations of Dielectric Methods Is it possible to Sense Oil and Protein Content in Grains? ISEMA, Kansas City, MO, USA.

Briggs, L. J. (1908). An Electrical Resistance Method for the Rapid Determination of the Moisture Content of Grain. Washington, D.C., U.S. Department of Agriculture, Bureau of Plant Industry.

Büchmann, N. B. and S. Runfors (1995): The Standardization of Infratec 1221 Near Infrared Transmission Instruments in the Danish Network Used for the Determination of Protein and Moisture in Grains. Journal of Near Infrared Spectroscopy 3(1): 35-42.

Burden, B. (1998). Working Instructions for Air Oven Methods. WI No: AO1-10. Kansas City, Missouri, USDA-GIPSA-TSD.

Bye, S. (1986): Checking and Handling Moisture Rebound in Seeds. The Sunflower(Aug/Sept): 1820.

Cole, K. S. and R. H. Cole (1941): Dispersion and Absorption in Dielectrics I. Alternating Current Characteristics. Journal of Chemical Physics 9: 341-351.

Cowe, I. A. and A. M. C. Davies (1995): Permanent Samples for Standardizing Near Infrared Instruments. Near Infrared Spectroscopy: The Future Waves--Proceedings of the 7th International Conference on Near Infrared Spectroscopy. A. M. C. Davies and P. Williams. Chichester, Eng., NIR Publications: 119-121.

Debye, P. (1929): Polar Molecules. New York, Chemical Catalog Companyp.

Emmert, S., M. Wolf, R. Gulich, S. Krohns, S. Kastner, P. Lunkenheimer and A. Loidl (2011): Electrode polarization effects in broadband dielectric spectroscopy. The European Physical Journal B-Condensed Matter and Complex Systems 83(2): 157-165.

Evans, D. E. (1982): The influence of temperature and grain moisture content on the intrinsic rate of increase of Sitophilus oryzae (L.) (Coleoptera: Curculionidae). Journal of Stored Products Research 18(2): 55-66. 
Federal Grain Inspection Service (1997). Sample Collection Responsibilities for Verifying the Accuracy of Moisture Meter Calibrations. Washington, D.C., United States Department of Agriculture.

Foster, K. R. and H. Schwan, P. (1989): Dielectric properties of tissues and biological materials: a critical review. Crit. Rev. Biomed. Eng. 17(1): 25-104.

Friesen, T. L., G. H. Brusewitz and R. L. Lowery (1988): An acoustic method of measuring moisture content in grain. Journal of Agricultural Engineering Research 39(1): 49-56.

Funk, D. B. (1990): Uniformity in Dielectric Grain Moisture Measurement. Uniformity by 2000-Highlights of an International Workshop on Maize and Soybean Quality. L. D. Hill. Champaign, Ill., Scherer Communications: 69-91.

Funk, D. B. (1997): Improving Accuracy and Uniformity of Measuring Moisture in the Market Channel. Managing Moisture in Grains and Oilseeds: 1997 Grain Quality Conference, Urbana, Illinois, University of Illinois.

Funk, D. B. (1998): The State of Grain Moisture Measurement in the United States. Third International Symposium on Humidity \& Moisture, London, England, National Physical Laboratory.

Funk, D. B. (1999): Dielectric Grain Moisture Measurement--Practical, Technical, and Regulatory Issues. Third Workshop on Electromagnetic Wave Interaction with Water and Moist Substances, Athens, Georgia, USDA - Agricultural Research Service.

Funk, D. B. (2001). An investigation of the nature of the radio-frequency dielectric response in cereal grains and oilseeds with engineering implications for grain moisture meters. $\mathrm{PhD}$ Physics and Engineering, University of Missouri-Kansas City.

Funk, D. B. and L. R. Engebretson (1996). Progress in Grain Quality Inspection. ASAE Annual Meeting. Phoenix, Ariz., American Society of Agricultural Engineers.

Funk, D. B. and Z. Gillay (2010): Dielectric Reference Materials for Mathematically Modeling and Standardizing Grain Moisture Meters. Transactions of the ASABE 53(1): 271-281.

Funk, D. B. and Z. Gillay. (2012). "UnifiedGrain MoistureAlgorithm Recipe Book." from http://www.gipsa.usda.gov/fgis/equipment/UGMA\%20Recipe\%20Book11-15-2012.pdf.

Funk, D. B., Z. Gillay and P. Meszaros (2007): Unified moisture algorithm for improved RF dielectric grain moisture measurement. Measurement Science \& Technology 18(4): 10041015 .

Funk, D. B. and W. E. Midden (1978). Analysis Instrument. U. S., Dickey-John Corporation.

Géczi, G. and P. Sembery (2002): Connections for Determining the Dielectric Properties of Agricultural Products. Hungarian Agricultural Research 12: 12-19. 
Gillay, Z. (2010). Dielektromos nedvességmérők kalibrációátvitelét befolyásoló tényezők. PhD., BCE.

Grimnes, S. and Ø. G. Martinsen (2000): Chapter 4 - Electrical properties of tissue. Bioimpedance and Bioelectricity Basics. London, Academic Press: 87-125.

Hardy, C. L., G. R. Rippke, C. R. Hurburgh, Jr. and T. J. Brumm (1995): Calibration and Field Standardization of Foss Grainspec Analyzers for Corn and Soybeans. Near Infrared Spectroscopy: The Future Waves--Proceedings of the 7th International Conference on Near Infrared Spectroscopy. A. M. C. Davies and P. Williams. Chichester, Eng., NIR Publications: 132-141.

Hart, J. R. (1967): A Method for Detecting Mixtures of Artificially Dried Corn with High-Moisture Corn. International Cereal Chemistry 44(1): 601-606.

Hasted, J. B. (1973): Aqueous Dielectrics. London, Chapman and Hallp.

Hasted, J. B. (1973): The Dielectric Properties of Heterogeneous Substances. Aqueous Dielectrics. London, Chapman and Hall: 117-135.

Hasted, J. B. (1973): The Water Molecule and Dielectric Theory. Aqueous Dielectrics. London, Chapman and Hall: 302.

Hemeda, M. A., C. R. Hurburgh and C. J. Bern (1982): Effects of corn variety, mechanical damage and drying temperature on electronic moisture meters. Paper, American Society of Agricultural Engineers(82-3547): 23 pp.

Hilhorst, M. A. (1998). Dielectric Characterisation of Soil Doctoral Thesis, Wageningen Agricultural Universitiy.

Hlynka, I. and W. Bushuk (1959): The weight per bushel. Cereal Science Today 4: 239-240.

Hoffman, K. J. and L. D. Hill (1976): Historical Review of the U.S. Grades and Standards for Grain. Illinois Agricultural Economics 16(1): 1-9.

Jones, R. N. (1978). Electrical Characteristics of Corn, Wheat, and Soya in the 1-200 MHz Range. Boulder, Colorado, National Bureau of Standards.

Klein, R. J., S. Zhang, S. Dou, B. H. Jones, R. H. Colby and J. Runt (2006): Modeling electrode polarization in dielectric spectroscopy: Ion mobility and mobile ion concentration of singleion polymer electrolytes. The Journal of chemical physics 124: p. 144903.

Kocsis, L., M. Herdovics, J. Deákvári and L. Fenyvesi (2011): Corn drying experiments by pilot dryer. International Scientific Conference Biosystems Engineering 2011, Tartu, Estonia, 1213 May 2011., Estonian Research Institute of Agriculture. 
Kraszewski, A. W. (1977): Prediction of the dielectric properties of two-phase mixtures. J. Microwave Power 12(3): 215-222.

Kraszewski, A. W., S. Trabelsi and S. O. Nelson (1999): Temperature-compensated and densityindependent moisture content determination in shelled maize by microwave measurements. Journal of Agricultural Engineering Research 72(1): 27-35.

Kuang, W. and S. O. Nelson (1998): Low-frequency dielectric properties of biological tissues: A review with some new insights. Transactions of the ASAE 41(1): 173-184.

Landau, L. D. and E. M. Lifshitz (1960): Electrodinamics of Continuous Media. Oyford, England, Pergamon Press.p.

Lawrence, K. C., S. O. Nelson and A. W. Kraszewski (1990): Temperature-Dependence of the Dielectric-Properties of Wheat. Transactions of the ASAE 33(2): 535-540.

Looyenga, H. (1965): Dielectric Constants of Heterogeneous Mixtures. Physica 31: 401-406.

Martin, C. R., Z. Czuchajowska and Y. Pomeranz (1986): Aquagram Standard Deviations of Moisture in Mixtures of Wet and Dry Corn. Cereal Chemistry 63(5): 442-445.

Meszaros, P. and D. B. Funk (2005): Measurement of moisture in grains at extreme temperatures Very high frequency dielectric method. Journal of Thermal Analysis and Calorimetry 82(1): 253-260.

Montross, M. D., F. W. Bakker-Arkema and R. E. Hines (1999): Moisture Content Variation and Grain Quality of Corn Dried in Different High-Temperature Dryers. Transactions of the ASABE 42(2): 427-433.

MSZ6367/3-83 (1983). Élelmezési, takarmányozási ipari magvak és hántolt termények vizsgálata, Nedvességtartalom meghatározása: 9.

Nelson, S. O. (1977): Use of Electrical Properties for Grain-Moisture Measurement. Journal of Microwave Power 12(1): 67-72.

Nelson, S. O. (1978): Frequency and Moisture Dependence of the Dielectric Properties of HighMoisture Corn. Journal of Microwave Power 13(2): 213-218.

Nelson, S. O. (1981): Review of Factors Influencing the Dielectric Properties of Cereal Grains. Cereal Chemistry 58(6): 487-491.

Nelson, S. O. (1983): Density Dependence of the Dielectric-Properties of Particulate Materials. Transactions of the ASAE 26(6): 1823-\&.

Nelson, S. O. (1983). Moisture, Frequency, and Density Dependence of the Dielectric Constant of Shelled, Yellow-Dent Field Corn. St. Joseph, Michigan, American Society of Agricultural Engineers. 
Nelson, S. O. (1983): Observations on the Density Dependence of Dielectric-Properties of Particulate Materials. Journal of Microwave Power and Electromagnetic Energy 18(2): 143152.

Nelson, S. O. (1991): Dielectric-Properties of Agricultural Products - Measurements and Applications. IEEE Transactions on Electrical Insulation 26(5): 845-869.

Nelson, S. O. (1992): Correlating Dielectric-Properties of Solids and Particulate Samples through Mixture Relationships. Transactions of the ASAE 35(2): 625-629.

Nelson, S. O. (1996): Determining dielectric properties of coal and limestone by measurements on pulverized samples. Journal of Microwave Power and Electromagnetic Energy 31(4): 215220 .

Nelson, S. O. (2005): Density-permittivity relationships for powdered and granular materials. IEEE Transactions on Instrumentation and Measurement 54(5): 2033-2040.

Nelson, S. O. and K. C. Lawrence (1991): Kernel Moisture Variation on the Ear in Yellow-Dent Field Corn. Transactions of the ASAE 34(2): 513-516.

Nelson, S. O., K. C. Lawrence and C. V. K. Kandala (1990): Comparison of Rf Impedance and Dc Conductance Sensing for Single-Kernel Moisture Measurement in Corn. Transactions of the ASAE 33(2): 637-641.

Nelson, S. O. and L. E. Stetson (1975): 250-Hz to 12-Ghz Dielectric Properties of Grain and Seed. Transactions of the ASAE 18(4): 714-\&.

Nelson, S. O. and L. E. Stetson (1976): Frequency and Moisture Dependence of Dielectric Properties of Hard Red Winter Wheat. Journal of Agricultural Engineering Research 21(2): 181-192.

Nelson, S. O. and T. S. You (1990): Use of Dielectric Mixture Equations for Estimating Permittivities of Solids from Data on Pulverized Samples. Physical Phenomena in Granular Materials 195: 295-300.

Pomeranz, Y. and Z. Czuckhajowska (1986): Rapid and Simple Detection of a Mixture of Wet and Dry Corn. Cereal Chemistry 63(3): 283-284.

Russel, W. B., D. A. Saville and W. R. Schowalter (1989): Colloidal Dispersions Cambridge, England, Cambridge University Pressp.

Sembery, P. (1976). Mezőgazdasági Szemes- és Szálasanyagok Dielektromos Jellemzői. Kanditátusi Értekezés.

Sembery, P. (2002): Mezőgazdasági termények dielektromos jellemzői. Budapest, Akadémiai Kiadóp. 
Sembery, P., G. Géczi, M. Kovács and M. Douba (1999): High Frequency and Microwave Dielectric Properties of Food Material. Hungarian Agricultural Engineering 12: 15-19.

Sembery, P., G. Géczi and G. Váczy (2001): Measurement Methods of Dielectric Properties of Mustard Seeds at Microwave Frequency. Hungarian Agricultural Research 10(3): 16-18.

Serdyuk, V. M. (2008): Dielectric Study of Bound Water in Grain at Radio and Microwave Frequencies. Progress in Electromagnetics Research 84: 379-406.

Shenk, J. S. and M. O. Westerhaus (1995): Comparison of Standardization Techniques. Near Infrared Spectroscopy: The Future Waves--Proceedings of the 7th International Conference on Near Infrared Spectroscopy. A. M. C. Davies and P. Williams. Chichester, Eng., NIR Publications: 112-115.

Sokhansanj, S. and S. O. Nelson (1988): Transient Dielectric Properties of Wheat Associated with Nonequilibrium Kernel Moisture Conditions. Transactions of the ASAE 31(4): 1251-1254.

Thorpe, G. R. (1981): Moisture diffusion through bulk grain. Journal of Stored Products Research 17(1): 39-42.

Trabelsi, S. and S. O. Nelson (1998): Density-independent functions for on-line microwave moisture meters: a general discussion. Measurement Science \& Technology 9(4): 570-578.

Trabelsi, S. and S. O. Nelson (2006): Temperature-dependent behaviour of dielectric properties of bound water in grain at microwave frequencies. Measurement Science \& Technology 17(8): 2289-2293.

Trabelsi, S. and S. O. Nelson (2007): On the accuracy of bulk density and moisture content prediction in wheat from near-field free-space measurements. Tm-Technisches Messen 74(5): 280-289.

Trabelsi, S. and S. O. Nelson (2007): Unified microwave moisture sensing technique for grain and seed. Measurement Science \& Technology 18(4): 997-1003.

Trabelsi, S. and S. O. Nelson (2008): Microwave dielectric sensing of moisture content in shelled peanuts independent of bulk density and with temperature compensation. 2008 IEEE Sensors Applications Symposium: 51-53.

USDA-GIPSA. (2012). "Equipment." from http://www.gipsa.usda.gov/fgis/equipment.html.

von Hippel, A. (1995): Complex Permittivity and Permeability. Dielectrics and Waves. Boston, Artech House. 1.

von Hippel, A. (1995): Interfacial and Space-Charge Polarization. Dielectrics and Waves. Boston, Artech House. 1. 
von Hippel, A. (1995): Representation of Dielectrics by Lumped Circuit Equivalents. Dielectrics and Waves. Boston, Artech House. 1.

Wilhelm, L. R., D. A. Suter and G. H. Brusewitz (2004): Drying and dehydration. Food Process Engineering Technology. St. Joseph, Michigan: 259-284.

Witten Jr, T. A. and S. R. Nagel (1975): Argand diagrams of dielectric response. Solid State Communications 16(2): 185-188.

Zimmerman, D. C. (1976): Determination of Moisture Content in Sunflowers with Electronic Moisture Meters. Journal of the American Oil Chemists Society 53(8): 548-550. 


\section{M2. RELATÍV DIELEKTROMOS ÁLLANDÓ FELSŐ HATÁR SZÁMOLÁSA}

A vízmolekulák orientációjából származó maximális relatív dielektromos állandó meghatározása a nedvességtartalom függvényében gabonaminták esetén.

A Landau-Lifshitz, Looyenga egyenletet 2 komponensü keverékekre felírva:

$$
\varepsilon_{\text {keverék }}^{\frac{1}{3}}=v_{1} \cdot \varepsilon_{1}^{\frac{1}{3}}+v_{2} \cdot \varepsilon_{2}^{\frac{1}{3}} \rightarrow \varepsilon_{\text {keverék }}=\left(v_{1} \cdot \varepsilon_{1}^{\frac{1}{3}}+v_{2} \cdot \varepsilon_{2}^{\frac{1}{3}}\right)^{3}
$$

ahol $\varepsilon_{\text {keverék }}$ a keverék relatív dielektromos állandója, $\mathrm{v}_{1}$ és $\mathrm{v}_{2}$ a keveréket alkotó komponensek relatív térkitöltése, $\varepsilon_{1}$ és $\varepsilon_{2}$ a komponensek relatív dielektromos állandója. Alkalmazva a (22) egyenletet egy gabonamintára, ahol a gabonaminta felfogható a nedves magok és a levegö keverékeként:

$$
\varepsilon_{\text {gabonaminta }}=\left(v_{\text {nedves mag }} \cdot \varepsilon_{\text {nedves mag }}^{\frac{1}{3}}+v_{\text {levego }} \cdot \varepsilon_{\text {levego }}^{\frac{1}{3}}\right)^{3}
$$

ahol $\varepsilon_{\text {gabonaminta }}$ a gabonaminta relatív dielektromos állandója, $\varepsilon_{\text {nedves mag }}$ és $\varepsilon_{\text {levegő }}$ a nedves mag és a

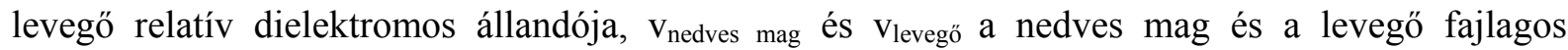
térfogata. Tudjuk, hogy a nedves mag és a levegő fajlagos térfogata felírható:

$$
v_{\text {nedves mag }}=\frac{V_{\text {nedves mag }}}{V} \text { és } v_{\text {levegö }}=\frac{V_{\text {levegö }}}{V}
$$

és

$$
V_{\text {nedves mag }}+V_{\text {levegő }}=V
$$

ahol $V_{\text {nedves mag }}$ a nedves magok térfogata, $V_{\text {levegö }}$ a levegö térfogata, $V$ az össztérfogat

A (4) egyenletben mindkét oldalt elosztva V-vel:

$$
\begin{gathered}
\frac{V_{\text {nedves mag }}}{V}+\frac{V_{\text {levegő }}}{V}=1 \\
v_{\text {nedves mag }}+v_{\text {levegő }}=1 \\
v_{\text {levegő }}=1-v_{\text {nedves mag }}
\end{gathered}
$$

A (5) egyenletet behelyettesítve a (1) egyenletbe és felhasználva, hogy a levegö relatív dielektromos állandója 1: 


$$
\begin{gathered}
\varepsilon_{\text {gabona minta }}=\left(v_{\text {nedves mag }} \cdot \varepsilon_{\text {nedves mag }}^{\frac{1}{3}}+\left(1-v_{\text {nedves mag }}\right) \cdot \varepsilon_{\text {levegó }}^{\frac{1}{3}}\right)^{3} \\
\varepsilon_{\text {gabona minta }}=\left[\left(\varepsilon_{\text {nedves mag }}^{\frac{1}{3}}-1\right) \cdot v_{\text {nedves mag }}+1\right]^{3}
\end{gathered}
$$

Egy átlagos mintára a nedves mag fajlagos térfogata megbecsülhető. Az egyenletben a

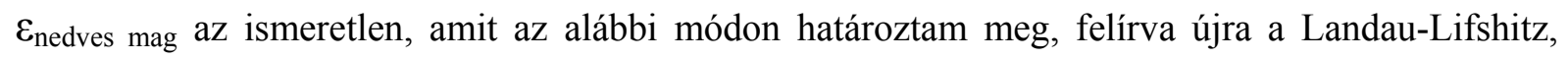
Looyenga egyenletet egy “csontszáraz” gabonaszem (továbbiakban száraz mag) és a víz keverékeként:

$$
\varepsilon_{\text {nedves mag }}=\left(\varepsilon_{\mathrm{víz}}^{\frac{1}{3}} \cdot v_{\text {víz }}+\varepsilon_{\text {száraz mag }}^{\frac{1}{3}} \cdot v_{\text {száraz mag }}\right)^{3}
$$

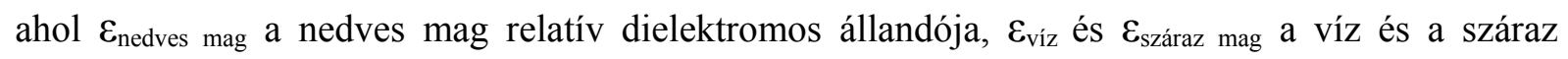
magrész relatív dielektromos állandója, $\mathrm{v}_{\mathrm{viz}}$ és $\mathrm{v}_{\mathrm{szá} r a z}$ mag a nedves magban lévő víz és a száraz magrész fajlagos térfogata. Ez utóbbiakat az alábbi módon határoztam meg felhasználva a nedves mag nedvességtartalmát $(\mathrm{M})$ :

$$
M=\frac{m_{v i z}}{m_{v i \mathrm{Z}}+m_{s z a ́ r a z ~ m a g}}=\frac{V_{v i \mathrm{z}} \cdot \rho_{v i z}}{V_{v i \mathrm{z}} \cdot \rho_{v i \mathrm{z}}+V_{s z a ́ r a z} \text { mag }^{\cdot} \rho_{\text {száraz mag }}}
$$

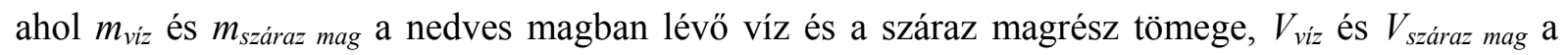

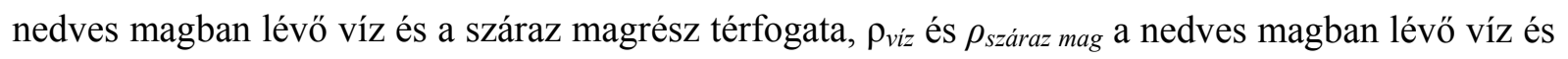
a száraz magrész sürüsége. A (8) egyenletben szereplő nedves mag nedvességtartalmát fajlagos térfogatokkal felírva:

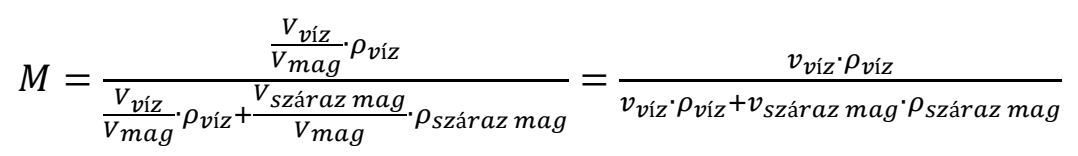

Tudjuk, hogy $v_{v i z}+v_{s z a ́ r a z ~ m a g}=1$. Felhasználva, hogy $\rho_{v i ́ z}=1 \mathrm{~g} / \mathrm{ml}$ a (9) egyenletetet felírhatjuk az alábbi módokon:

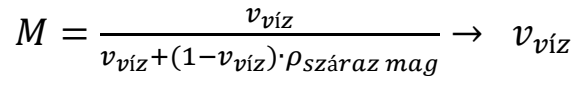

$$
\begin{aligned}
& M=\frac{1-v_{\text {Száraz mag }}}{1-v_{\text {Száraz mag }}+v_{\text {Száraz mag }} \cdot \rho_{\text {Száraz mag }}} \rightarrow v_{\text {Száraz mag }}
\end{aligned}
$$

Az előbbi egyenletekből $v_{v i ́ z}$-t és $v_{s z a ́ r a z ~ m a g}$-ot kifejezve az alábbi összefüggéseket kapjuk: 


$$
\begin{gathered}
v_{v i ́ z}=\frac{M \cdot \rho_{\text {Száraz mag }}}{M \cdot\left(\rho_{\text {Száraz } m a g}-1\right)+1} \\
v_{\text {Száraz mag }}=\frac{1-M}{M \cdot\left(\rho_{\text {száraz mag }}-1\right)+1}
\end{gathered}
$$

A (10) és (11) egyenleteket behelyettesítve a (12) egyenletbe a nedves gabona mag relatív dielektromos állandóját felírhatjuk az alábbi módon:

$$
\varepsilon_{\text {nedves mag }}=\left(\varepsilon_{\mathrm{víz}}^{\frac{1}{3}} \cdot \frac{M \cdot \rho_{\text {száraz mag }}}{M \cdot\left(\rho_{\text {száraz mag }}-1\right)+1}+\varepsilon_{\text {száraz mag }}^{\frac{1}{3}} \cdot \frac{1-M}{M \cdot\left(\rho_{\text {száraz mag }}-1\right)+1}\right)^{3}
$$

ahol $\varepsilon_{\text {nedves mag }}$ és $\varepsilon_{\text {száraz }}$ mag a nedves és a száraz gabonaszem relatív dielektromos állandója, $\varepsilon_{\text {víz }}$ a

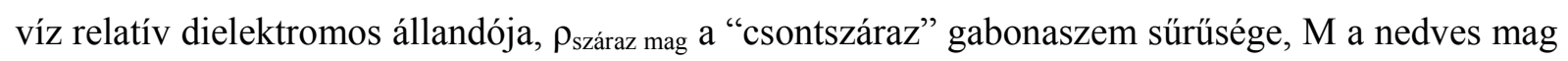
nedvességtartalma. A nedves mag relatív dielektromos állandója becsülhető az irodalmi adatokból.

Az előbbi összefüggést felírva egy nedves gabonaszemekből és a levegő keverékéből álló gabonamintára (felhasználva, hogy a levegő relatív dielektromos állandója 1 és sürüsége a keverékben megközelítően 0):

$$
\varepsilon_{\text {gabonaminta }}=\left[v_{\text {nedves mag }} \cdot\left(\varepsilon_{\text {víz }}^{\frac{1}{3}} \cdot \frac{M \rho_{\text {száraz mag }}}{M \cdot\left(\rho_{\text {száraz mag }}-1\right)+1}+\varepsilon_{\text {száraz mag }}^{\frac{1}{3}} \cdot \frac{(1-M)}{M \cdot\left(\rho_{\text {száraz mag }}-1\right)+1}-1\right)+1\right]^{3}(56
$$

ahol $\varepsilon_{\text {gabonaminta }}$ a teljes gabonaminta (nedves gabonaszemek és a levegö)relatív dielektromos állandója, v vedves mag a mintában a nedves gabonaszemek fajlagos térfogata. Az így kapott összefüggéssel számolt értéknél nagyobb (mért)relatív dielektromos állandó nem magyarázható csak a poláris vízmolekulák forgásával. A számításhoz felhasználtuk az alábbiakat: $\varepsilon_{\text {víz }}=78,5$, $v_{\text {nedves mag }}=0,7, \rho_{\text {száraz mag }}=1,4 \mathrm{~g} / \mathrm{ml}$ és $\varepsilon_{\text {száraz mag }}=2$. 


\section{M3. NYOMÁS HATÁSA AZ ARGAND GÖRBÉKRE}

\begin{tabular}{|c|c|c|c|c|c|}
\hline \multicolumn{6}{|c|}{ Dielektromos mérés nyomás alatt } \\
\hline \multicolumn{2}{|c|}{ GAC tesztcella } & \multicolumn{2}{|c|}{ Hengerkondenzátor } & \multicolumn{2}{c|}{$\begin{array}{c}\text { Módosított } \\
\text { hengerkondenzátor }\end{array}$} \\
\hline Erő (N) & Nyomás (kPa) & Erő (N) & Nyomás (kPa) & Erő (N) & Nyomás (kPa) \\
\hline 0 & 0.0 & 0 & 0.0 & 0 & 0.0 \\
\hline 5 & 1.4 & 5 & - & 5 & - \\
\hline 10 & 2.8 & 10 & 1.5 & 10 & 1.9 \\
\hline 15 & 4.2 & 15 & - & 15 & - \\
\hline 20 & 5.6 & 20 & 3.0 & 20 & 3.9 \\
\hline 25 & 7.0 & 25 & - & 25 & - \\
\hline 50 & - & 50 & 7.6 & 50 & 9.7 \\
\hline 75 & - & 75 & 11.4 & 75 & 14.6 \\
\hline 100 & - & 100 & 15.2 & 100 & 19.4 \\
\hline
\end{tabular}
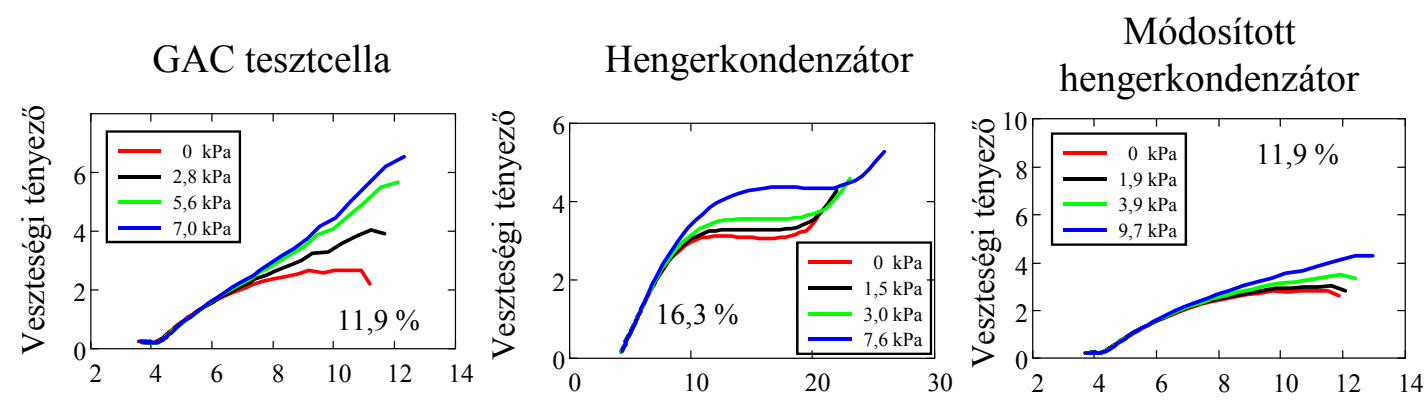

Rel. dielektromos állandó

Rel. dielektromos állandó
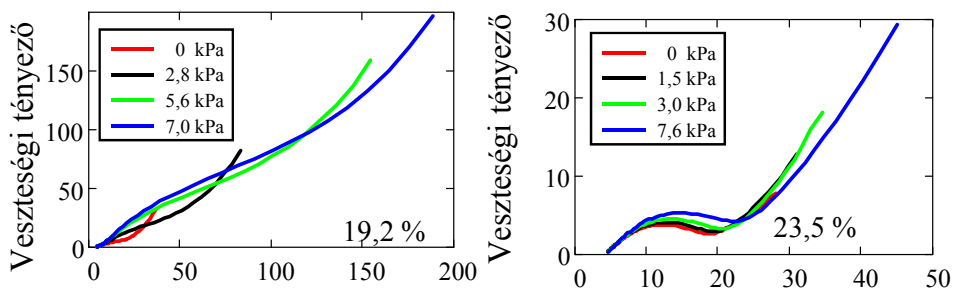

Rel. dielektromos állandó

Rel. dielektromos állandó

Rel. dielektromos állandó
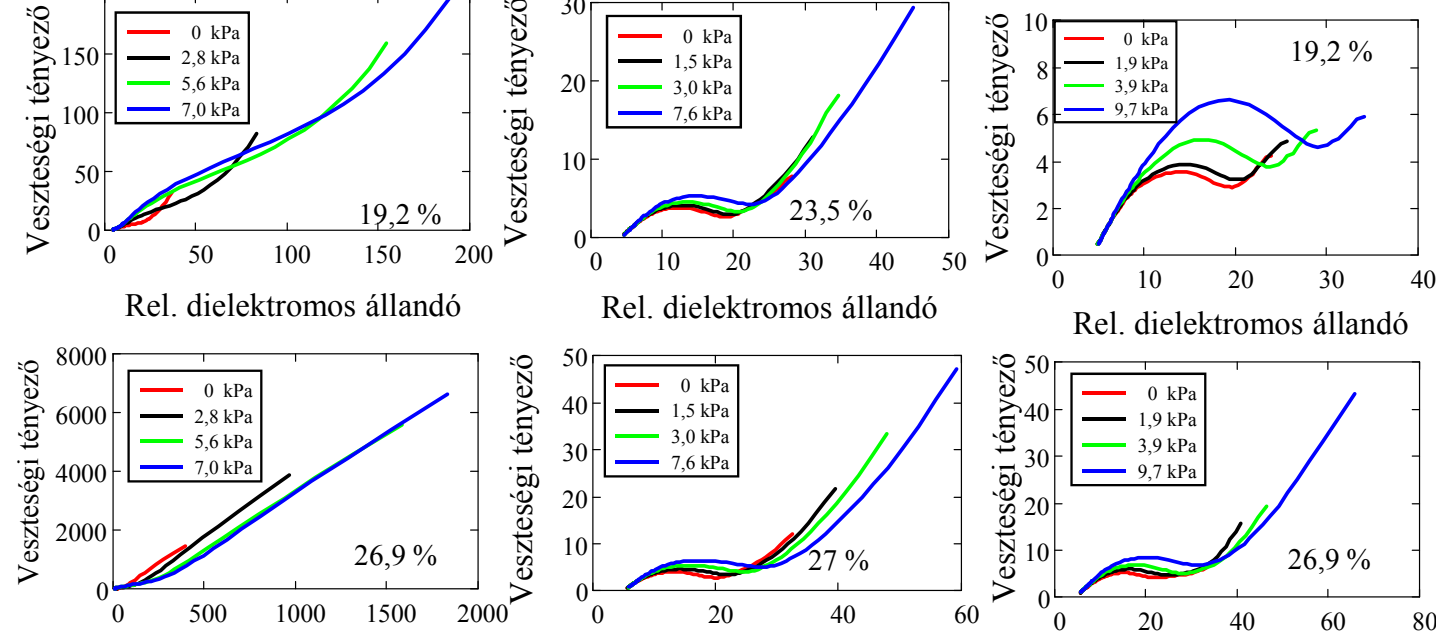

Rel. dielektromos állandó

Rel. dielektromos állandó

Rel. dielektromos állandó

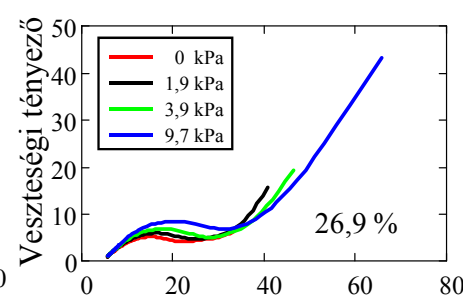

Rel. dielektromos állandó

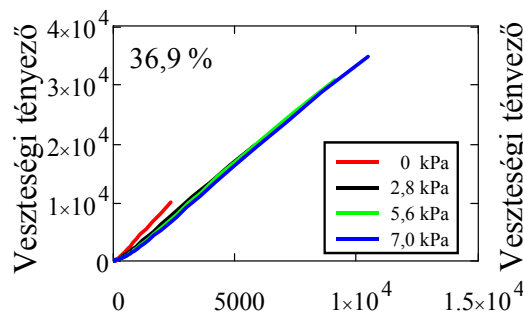

Rel. dielektromos állandó

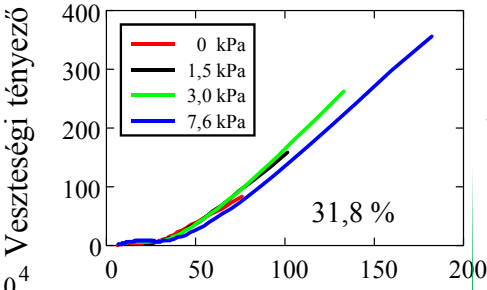

Rel. dielektromos állandó

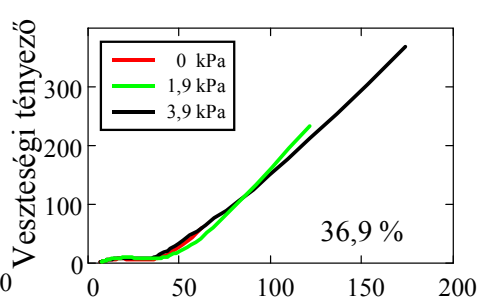

Rel. dielektromos állandó

Különböző nedvességtartalmú kukorica minták Argand ábrái. 


\section{KÖSZÖNETNYILVÁNÍTÁS}

\section{EZÚTON IS SZERETNÉM MEGKÖSZÖNNI:}

- dr. Fekete András professzor úrnak, hogy elindított ezen az úton, és hogy a hosszú évek alatt mindig támogatott,

- dr. David Funknak a több éven át tartó önzetlen segítségét,

- dr. Felföldi József professzor úrnak minden emberi és szakmai segítségét,

- Férjemnek, dr. Gillay Zoltánnak a szakmai segítségét és hogy időt és a hátteret biztosított a számomra,

- dr. Vozáry Eszternek az értékes tanácsait,

- Linda M. Funknak az angol nyelvben nyújtott segítségét

- A Fizika-Automatika Tanszék minden dolgozójának a támogatást,

\section{SZERETNÉK TOVÁBBÁ KÖSZÖNETET MONDANI:}

- Családomnak és barátaimnak a bíztatást és mindazt a segítséget, amely nélkül e dolgozat nem készülhetett volna el.

- Fiaimnak, Gergelynek, Benedeknek és Ágostonnak a támogatást és a türelmet. 